\title{
Epigenetikai faktorok hatásának vizsgálata a Huntington- kór patomechanizmusában Drosophila modellben
}

\author{
Doktori (Ph.D.) értekezés
}

\author{
Varga Júlia \\ Témavezető: Dr. Bodai László \\ tanszékvezető egyetemi docens
}

Szegedi Tudományegyetem, Természettudományi és Informatikai Kar, Biokémiai és Molekuláris Biológiai Tanszék

Szegedi Tudományegyetem, Természettudományi és Informatikai Kar, Biológia Doktori Iskola

Szeged

2020 


\section{Tartalomjegyzék}

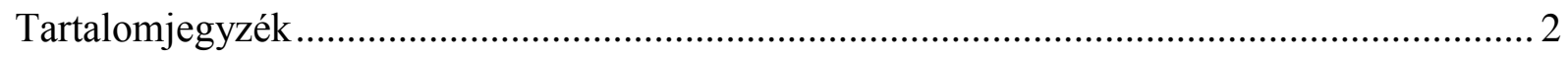

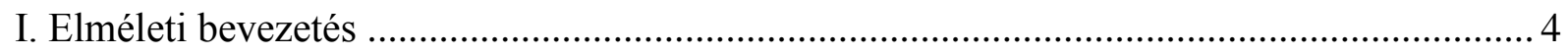

I.1. Az eukarióta kromatin szerkezete ....................................................................... 4

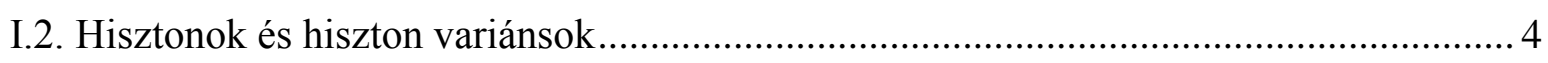

I.3. A kromatin szerkezet módosításai szabályozó szereppel bírnak ................................ 6

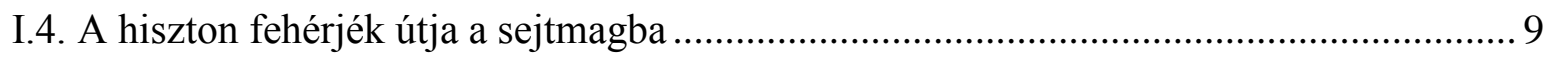

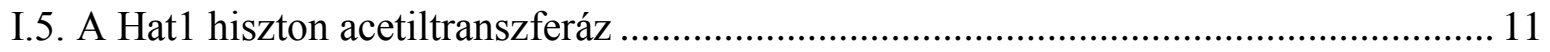

I.6. Epigenetikai változások a neurodegeneratív betegségekben ...................................... 14

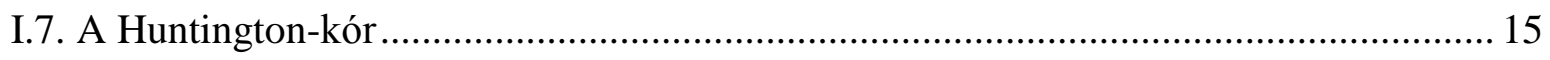

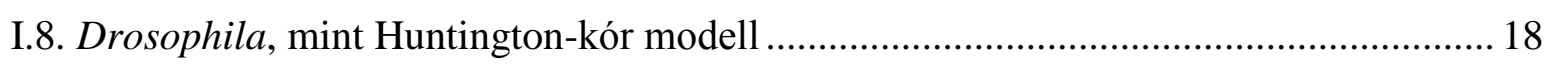

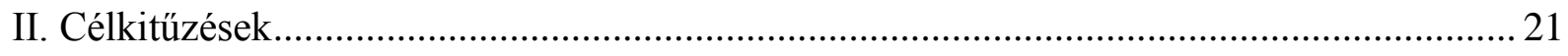

II.1. A Drosophila Hat1 általános jellemzése és hatásának vizsgálata a Huntington-kór

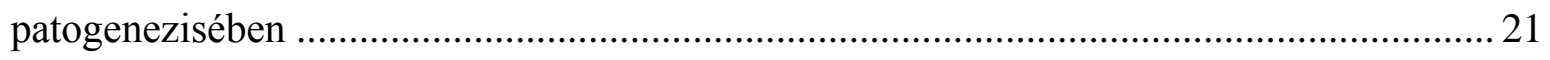

II.2. His4r variáns hiszton fehérjék acetilációs módosításainak hatása a Huntington-kór

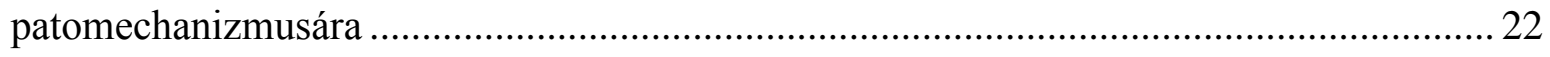

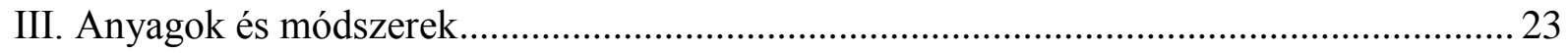

III.1. Drosophila fenntartás, keresztezések és fenotípus vizsgálatok ............................... 23

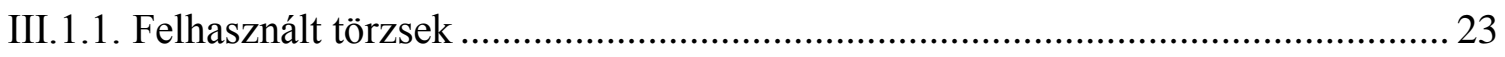

III.I.2. Hat1 deléció létrehozása transzpozon remobilizálással .................................... 23

III.1.3 Hat1 mutánsok életképességének, élettartamának és fekunditásának vizsgálata.. 23

III.1.4. Szem pigment koncentrációjának meghatározása spektrofotometriával.............. 24

III.1.5. Cirkadián ritmus és napi aktivitás vizsgálata ..................................................... 24

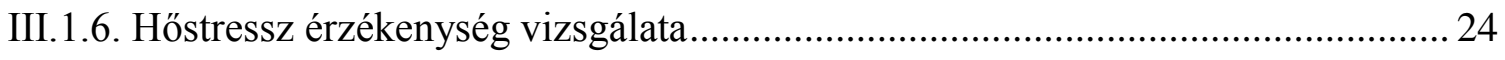

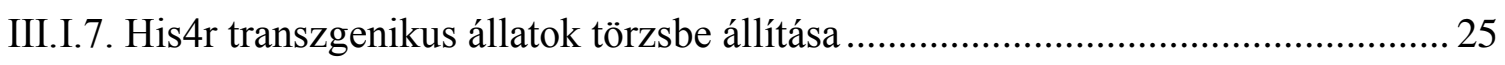

III.1.8. Idegsejtekben expresszált His4r konstrukciók életképességre gyakorolt hatásának

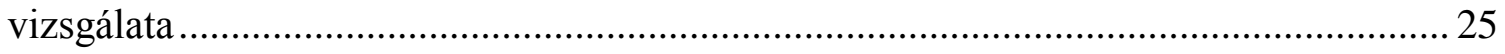

III.1.9. Életképesség és élettartam vizsgálatok mHtt-t expresszáló egyedekben ............. 25

III.1.10. Neurodegeneráció vizsgálata pseudopupil assay-el ....................................... 26

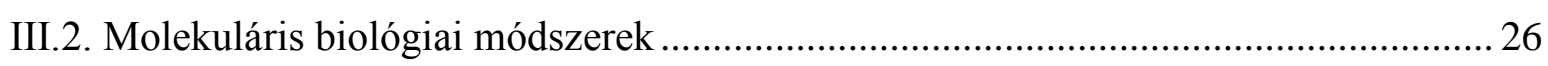

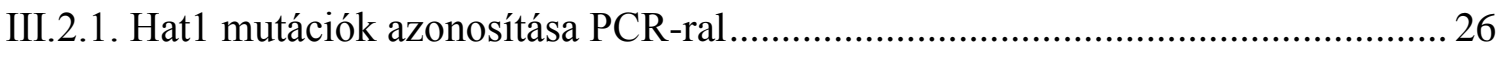

III.2.2. Pontmutáns His4r transzgének és transzgenikus törzsek létrehozása .................. 27

III.2.3. Az integrált pontmutáns His4r transzgének szekvencia ellenőrzése.................... 28 
III.2.4. mRNS szint vizsgálata RT-qPCR-ral 29

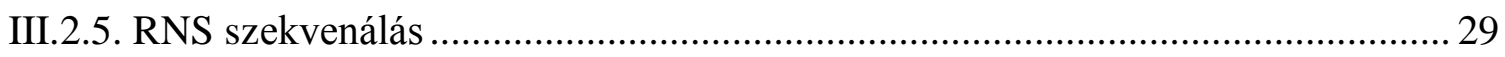

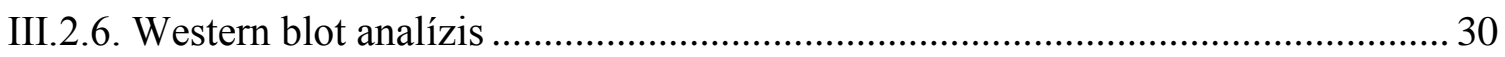

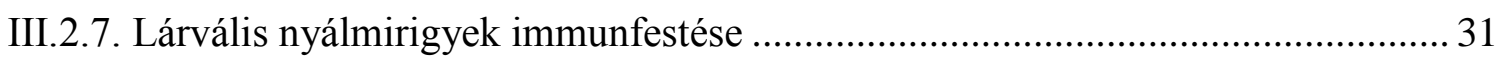

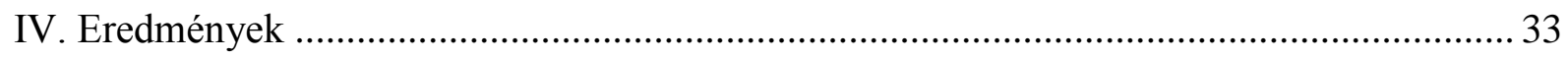

IV.1. A Drosophila Hat1 általános jellemzése és funkciójának vizsgálata a Huntington-

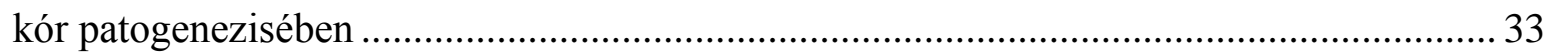

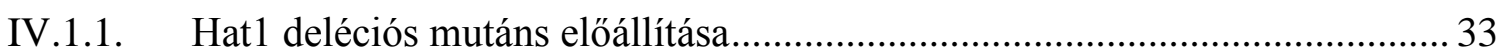

IV.1.2. A Hat1 H4K5 és K12 specifikus acetiltranszferáz aktivitással rendelkezik .. 34

IV.1.3. K5 és K12 acetiláció hiányának hatása a His4r sejtmagi lokalizációjára........ 38

IV.1.4. A Hat1 deléció csökkent életképességet és élettartamot eredményez ............ 39

IV.1.5. A Hat1 nem szükséges a fertilitáshoz, de a túltermelése nöstényekben megnöveli a lerakott peték számát ....................................................................... 42

IV.1.6. A Hat1 gén neuronális kifejeződésének vizsgálata az öregedés során ........... 43

IV.1.7. A Hatl gén deléciójának hatása a napi aktivitásra és cirkadián ritmusra....... 43

IV.1.8. Kromatin szerveződésre gyakorolt hatás vizsgálata PEV analízissel............. 45

IV.1.9. A Hat1 deléció transzkriptomikai hatásának vizsgálata ............................... 47

IV.1.10. A Hat1 deléció nem befolyásolja a hőstressz érzékenységet .........................50

IV.1.11. Csökkent Hat1 dózis hatásának vizsgálata Huntington-kór modellben ..........51

IV.2. His4r hiszton fehérjék acetilációs módosításainak hatása a Huntington-kór

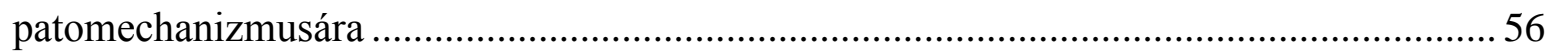

IV.2.1. His4r pontmutáns konstrukciók és transzgenikus Drosophila vonalak előállítása 56

IV.2.2. A His4r transzgének kifejeződésének vizsgálata.........................................56

IV.2.3. A His4r pontmutánsok életképességre gyakorolt hatásának vizsgálata ......... 60

IV.2.4. A pontmutáns His4r transzgének expressziója nem idéz elő fotoreceptor neuron degenerációt

IV.2.5. A His4r pontmutációk hatása a mutáns Htt kiváltotta patológiás folyamatokra 62

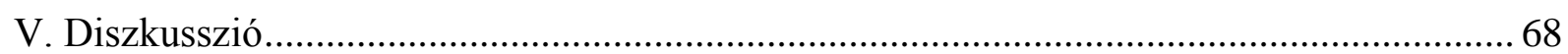

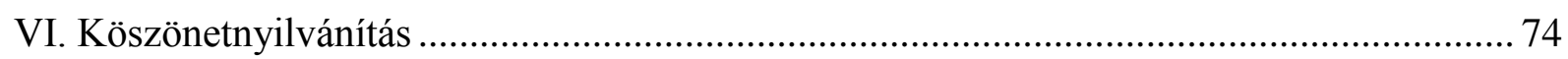

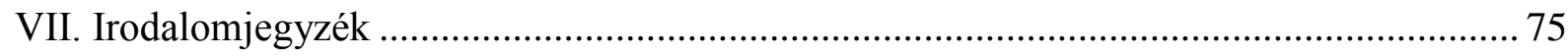

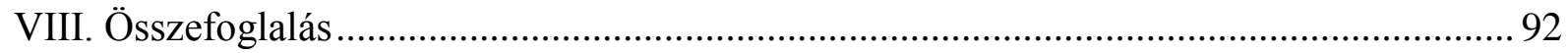

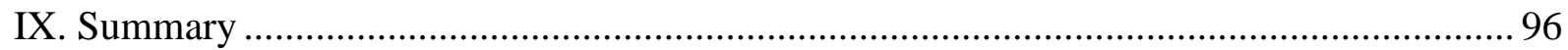

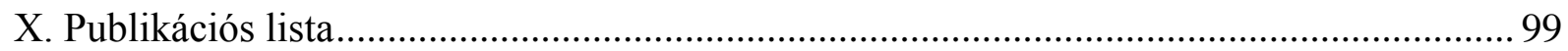




\section{Elméleti bevezetés}

\section{I.1. Az eukarióta kromatin szerkezete}

A génjeink viszonylag változatlan formában történő átörökítéséért felelős DNS-nek, mely a humán genom esetében mintegy $6,6^{*} 10^{9}$ bázispárnyi és körülbelül 2 méter hosszúságú, nagy mérete miatt tömörödnie kell, hogy beleférjen a közelítőleg $10 \mu \mathrm{m}$ átméröjü sejtmagba. Ahhoz, hogy a sejtmagban rendezett és funkcióit ellátni képes módon elférjen, a DNS egy kromatinnak nevezett nukleoprotein komplexet alkot föként hiszton fehérjékkel, és emellett más fehérje és RNS alkotókkal együtt. A komplex legkisebb alapegységei a nukleoszómák, melyeket 4 hiszton fehérje típus és a hozzájuk kötődő negatív töltésü DNS alkot. Ezek a „core” hiszton fehérjék a H2A, H2B, H3 és a H4. Két H2A-H2B és két H3-H4 dimer hozza létre a hiszton oktamert, amelyre 147 bázispárnyi DNS tekeredik rá. A hiszton oktamer és DNS által létrehozott struktúrára kívülröl a H1 linker hiszton fehérje kapcsolódik, stabilizálva a köztük lévő kapcsolatot. A nukleoszómák gyöngyszerűen helyezkednek el a DNS láncon, ezt a „gyöngyfüzér" szerkezetet nevezik átméröje után $10 \mathrm{~nm}$-es rostnak. A H1 hiszton kapcsolódása a „gyöngyfüzér” felcsavarodásához vezet. Egy „csavarulatot” 6 nukleoszóma alkot és átmérője megközelítőleg $30 \mathrm{~nm}$, az így felépülő struktúrát nevezik szolenoid szerkezetnek. Ezek a $30 \mathrm{~nm}$-es kromatin fonalak hurkokat alkotnak és a DNS így további tömörödést, kondenzációt ér el. ${ }^{1}$ A kromatin által felvett struktúra függ a kapcsolódó linker hiszton típusoktól is. ${ }^{2}$ A magasabb rendü kromatin struktúra kialakításában részt vesznek más fehérjék is, mint amilyen a lamin, a topoizomeráz II, az SMC (Structural Maintenance of Chromosomes) fehérjék, valamint a centromer és telomer kialakításában részt vevő fehérjék. ${ }^{3}$

\section{I.2. Hisztonok és hiszton variánsok}

A hiszton fehérjék méretüket tekintve kicsi, 11-16 kDa méretü bázikus fehérjék, melyek evolúciósan nagymértékü konzerváltságot mutatnak. Azonban nem minden organizmus alkalmaz hiszton fehérjéket a DNS „csomagoláshoz”. A prokariótákban számos különböző, filogenetikailag egymással kapcsolatot nem mutató fehérje tölti be ezt a funkciót, az Archaeákban találhatóakról úgy vélik, hogy az eukarióta hisztonok evolúciós ősei lehetnek. ${ }^{4}$ Az eukarióták országán belül található dinoflaggelláták szintén nem rendelkeznek hiszton fehérjékkel, hanem azoktól független eredetü kisméretü bázikus fehérjéket használnak DNSük tömörítésére. ${ }^{3,5} \mathrm{Az}$ emlősök spermatozoái pedig úgynevezett protamin fehérjéket alkalmaznak erre a célra. ${ }^{6}$

Az eukarióták többségében 4 típusú hiszton fehérje alkotja a nukleoszóma magját alkotó oktamer komplexet (nukleoszóma core partikulum), ezek a H2A, H2B, H3 és H4 hiszton fehérjék, melyeket kanonikus vagy „,core” hisztonoknak is nevezünk. ${ }^{7}$ A kanonikus hisztonok a genomban úgynevezett gén klaszterekben helyezkednek el, ezekben a klaszterekben a hiszton fehérje géneknek számos kópiája található meg. ${ }^{8}$ A hiszton gének egyedi 5'- és 3'UTR régiókkal, valamint promóterekkel rendelkeznek. A kanonikus hiszton fehérjék speciális RNS-ről íródnak, melyek poly A farok nélküliek. ${ }^{9}{ }^{10}$ Ezek a hiszton fehérjék kétféle strukturális doménnel rendelkeznek. Az úgynevezett „histone fold domain” pozitív töltése 
révén képes kölcsönhatásba lépni a negatív töltésü DNS-el, illetve a hiszton-hiszton kapcsolatok kialakulása is ezen keresztül jön létre. ${ }^{11}{ }^{12}$ A másik doménjük pedig egy flexibilis, nukleoszómából farki rész szerü módon kinyúló struktúra, amely magas lizin aminosav tartalma révén számos poszt-transzlációs módosítás helyéül szolgál. ${ }^{13}{ }^{14}$ Ilyen farki struktúrával a hiszton fehérjék az N- és a C-terminális részükön is rendelkezhetnek. ${ }^{11}{ }^{15} \mathrm{~A}$ hiszton fehérjék magas affinitással kötődnek a DNS-hez, annak kis árok részét ismerik fel és nem szekvencia-specifikus módon kötődnek hozzá. Azonban egyes DNS szekvencia részek nagyobb preferenciával kötnek nukleoszómákat, így pl. az AT dinukleotidok 10 bp-nyi periodicitású ismétlődései. 16121718

A H1 linker hiszton kívülről kötődik hozzá a DNS-hez és a core hiszton fehérjékhez. Egy központi globuláris doménből és az ezt határoló N- és C-terminális doménekből épül fel. ${ }^{19}$ Két fö helyen kapcsolódik a kromatin struktúrához, az egyik a nukleoszómális felszínen található, a másik pedig két nukleoszóma közötti régióban a DNS kis árok részén. ${ }^{20}$ Ehhez a kötődéshez szükséges mind a C-terminális rész, mind a globuláris domén. ${ }^{21} \mathrm{~A} H 1$ hiszton gén szintén a hiszton klaszterekben található több kópiában. ${ }^{8}$

A kanonikus hisztonok helyettesíthetőek hiszton variánsokkal, melyek a hiszton gén klasztereken kívül kódoltak, és kanonikus megfelelőjükhöz képest szekvencia eltéréseket hordoznak. Beépülésükre replikációkor vagy replikációtól függetlenül is sor kerülhet. A hiszton variánsok egyedi kölcsönhatásokat képesek létrehozni a kromatin-asszociált fehérjékkel - mint amilyenek a kromatin átrendező fehérjék -, vagy megváltoztathatják a kromatin szerkezetét. ${ }^{22}$

A H2A hiszton fehérjének mára többféle variánsát sikerült azonosítani különféle többsejtü élölényekben, ilyenek a H2A.X, a H2A.Z, a H2A.B és a macro-H2A. Az egyik legismertebb közülük a macro-H2A, amely a legnagyobb hiszton variáns, mérete a kanonikus H2A majdnem háromszorosa. Emlösökben az inaktív X-kromoszómához kötődik, valamint szerepet játszik a DNS hibajavításban és a rekombinációban is. ${ }^{23} 24$

A H3-as hiszton fehérjének is több variánsa ismert, emlösökben ilyen a H3.1, H3.2, H3.3 és CENP-A, melyek fehérje szekvenciája nagyon hasonló. A H3.3 kromatinba épülése egy nyitottabb konformációt eredményez elősegítve ezzel a transzkripciót. ${ }^{25}$ A CENP-A fehérje a kanonikus $\mathrm{H} 3$-at fóként a centromerikus régiókban cseréli le replikáció független módon. ${ }^{26} \mathrm{~A}$ centromer pozíciója a kromoszómán nem DNS szekvencia által meghatározott, hanem a legtöbb eukarióta organizmusban a CENP-A jelenléte jelöli ki, amely a centromer és kinetochor kialakításában és fenntartásában nélkülözhetetlen. ${ }^{27} 2829$

A Drosophila His4r H4 hiszton „variáns” aminosav szekvenciájában nem tér el a kanonikus hiszton fehérjétől, csak szabályozásában. ${ }^{30}$ A humán $\mathrm{H} 4$ génváltozatok változatos szerveződésű proximális promótereik révén és a génklaszterek általános kromatinizációjának eltérései miatt szabályozásukban eltérnek egymástól. ${ }^{31}$ Egy nemrégiben felfedezett humán H4 hiszton változat a $\mathrm{H} 4 \mathrm{G}$, amelynek hiányzik a $\mathrm{C}$-terminális farki része és a kanonikus $\mathrm{H} 4$ fennmaradó részével is csak 85\%-os hasonlóságot mutat. A H4 hiszton változatokra jellemző, hogy különböző rákos szövetekben eltérő expressziót mutatnak. ${ }^{32}$ 
A H1 linker hiszton fehérjének is számos változatos szekvenciájú variánsa létezik a többsejtü élőlényekben. A H1 altípusok közül a H1.0, a H1.X, a H1T2, a HILS1 és a H1oo tekinthető valóban hiszton variánsnak, ugyanis ezek expressziója folyamatos a sejtciklus során és kromatinba épülésük replikáció független módon történik. ${ }^{33} 34$

\section{I.3. A kromatin szerkezet módosításai szabályozó szereppel bírnak}

Az epigenetikai szabályozás olyan öröklődő változásokat hoz létre, amelyek nem a DNS szekvenciában kódoltak. A hiszton fehérjék kovalens módosításai, mint amilyen például az acetiláció, a foszforiláció, a metiláció és az ubikvitináció az N-terminális hiszton végeken, hipotetikusan egy úgynevezett hiszton-kódot képeznek, amely szabályozó hatással bír a génexpressziós folyamatokra. ${ }^{35} 36$ A hiszton végek kovalens módosításai interakciós felületekként szolgálhatnak a nukleoszóma összerendeződés során kromatin átrendező fehérjék és transzkripciós regulátor fehérjék toborzásához (1. ábra). Néhány hiszton módosítás rövid életű és génexpresszió aktiválást vagy gátlást vált ki, míg mások a sejtosztódások során öröklödhetnek. ${ }^{37}$

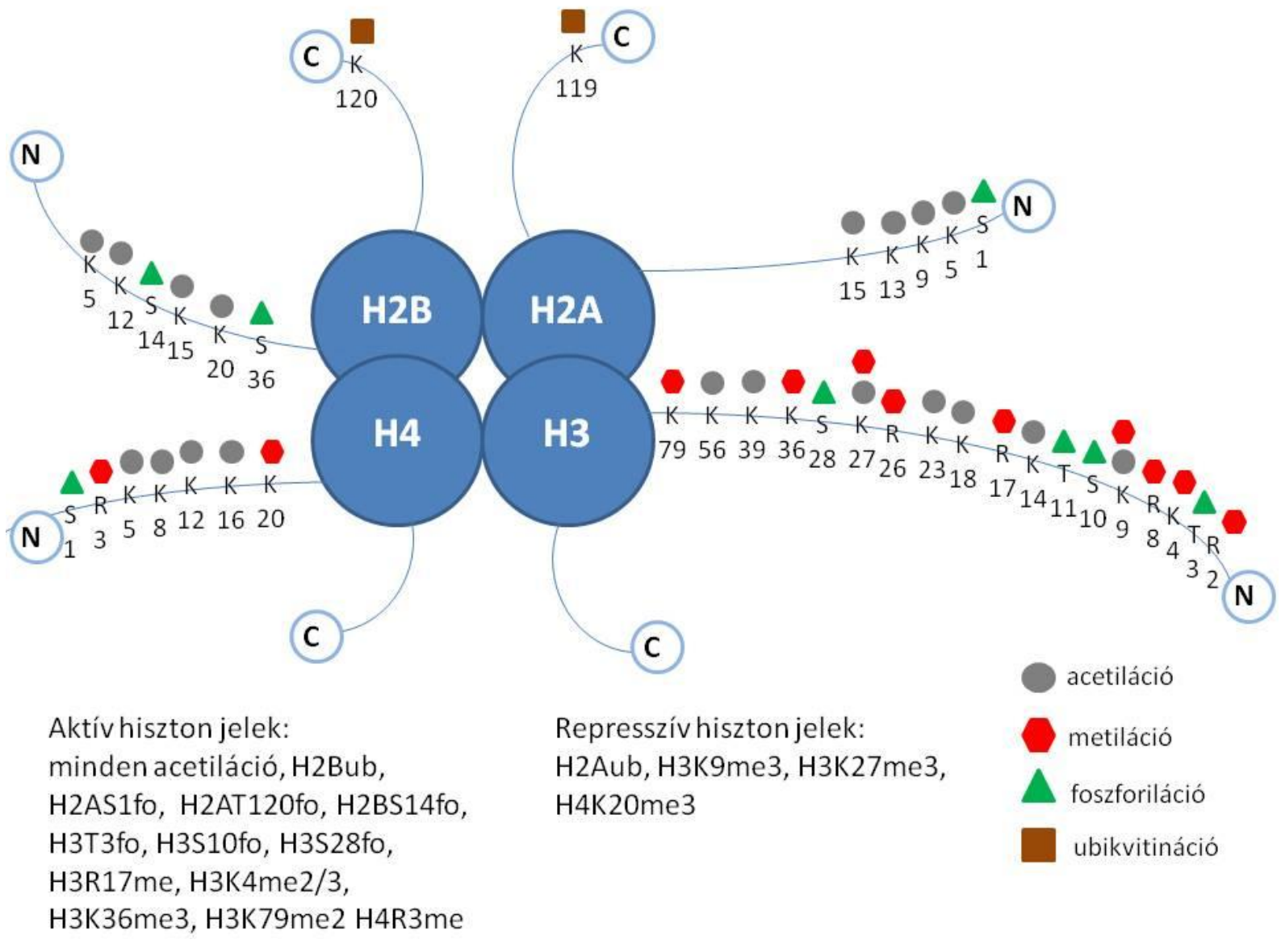

1. ábra. Hiszton fehérjékre jellemző poszt-transzlációs módosítások. $A H 2 A, H 2 B$, H3 és H4 hiszton fehérjéket eltérő $\mathrm{N}$ - és C-terminális módosítások jellemzik, melyek eltérő funkciót töltenek be a kromatin struktúrájának szabályozása során. 
A kromatin struktúrája szabályozza az esszenciális sejtmagi folyamatokat, mint amilyen a transzkripció, DNS replikáció és a DNS hibajavítás. Egy gén transzkripciós aktivitásának szabályozásában fontos szerepet tölt be a lokális kromatin szerkezet. Amikor a DNS a nukleoszóma köré tekeredik, hozzáférhetetlenné válik más DNS-kötő fehérjék számára, így pl. a transzkripciós faktorok sem tudnak kapcsolatot létesíteni vele. ${ }^{16}$ A konformációs eltérések a nukleuszban lokálisan jelentkeznek, és a transzkripciót szabályozzák. A kompaktabb kromatin szerkezet akadályozza a transzkripciós folyamatokat, míg a nyitottabb struktúra transzkripciós faktorok számára elérhetővé teszi az adott DNS szakaszt. ${ }^{38}$ Vannak erősen kondenzált kromatin szakaszok, melyek a sejtosztódás késői S-fázisában replikálódnak és a meiotikus rekombinációban sem vesznek részt. Ezeken a szakaszokon jellemzően alacsony a transzkripciós aktivitás, vagy egyáltalán nincsen. Az ilyen kromatin típust heterokromatinnak, míg az aktívan átíródó genomi régiókat eukromatinnak nevezik. ${ }^{3} 37$

A 2000-es évek elején Drosophilában kétféle heterokromatin típust sikerült azonosítani különböző felépítésü fehérjékkel és eltérő szabályozó funkciókkal. A felfedezett két heterokromatin és egy eukromatin típuson kívül Filion és munkatársai 2010-ben közölt cikkükben további két kromatin típus azonosítását és jellemzését írták le, amely alapján öt kromatin típust különítettek el. Kutatásaik alapján a muslica genom specifikus kombinációjú fehérjékkel határolt nagy régiókra osztható és az öt kromatin típus egyedi fehérje kombinációkat tartalmaz. ${ }^{39}$

A Filion és munkatársai által azonosított „kék” és a „,zöld” kromatin nagyon hasonlóak a korábban azonosított kromatin típusokkal. A „zöld” kromatin megegyezik a klasszikus heterokromatinnal, amelyet a SU(VAR)3-9, HP1, LHR, HP6, HP1, RPD3 kölcsönható fehérjék és H3K9me2 dúsulás jelöl. ${ }^{40}{ }^{41}$ A „,kék” kromatin a korábban is azonosított Polycomb-csoport (PcG) által represszált kromatinnak felel meg és PC, E(Z), PCL, SCE, RPD3, EFF fehérjék kötése, valamint H3K27me3-ós kromatin jel magas szintje jellemzi. ${ }^{42} 43$ 4439 A ,fekete" kromatin egy csendes típusa a kromatinnak, amely a genom nagy részére kiterjed és feltételezhetően aktív szerepet játszik a transzkripcionális csendesítésben. Jellemző kölcsönható partnerei a H1 hiszton, D1, IAL, SUUR, SU(HW), LAM, és EFF. ${ }^{39}$ Szövetexpressziós adatok alapján, vannak gének a „fekete” kromatinban, amelyek képesek aktívvá válni. Gazdag a magas szinten konzervált nem-kódoló elemekben (HCNEs), melyek feltételezhetően a génszabályozásban vesznek részt és valószínüsíthetően szerepet játszanak az egyedfejlődésben. ${ }^{2} 39$ A ,piros” és ,sárga” kromatin a transzkripcionálisan aktív eukromatinra jellemző jegyeket hordoz. Ezekben a kromatin típusokban magas szintü az mRNS képződés, magas szinten van jelen az RNS polimeráz, magas a H3K4me2-ós és H3K79me3-ós aktív jelek szintje, és kevés a H3K9me2-ós és a H3K27me3-ós represszív jelek mennyisége. ${ }^{39}$ A ,piros” és ,sárga” kromatinra jellemző fehérjék az RPD3, SIR2, SIN3A, DF31, ASH2, MAX. Csak a „piros” kromatinra jellemző a BRM, SU(VAR)2-10, MED31, az 55 kDa-os CAF1 alegység, valamint az olyan DNS kötő faktorok, mint az ECR, GAF, JRA. Az MRG15 chromodomént tartalmazó fehérje és az aktív H3K36me3-ós jel, pedig csak a „sárga" kromatinban mutat dúsulást. 46474849 A ,piros” kromatint erős origó felismerő komplex (ORC) dúsulás is jellemzi ${ }^{50}$, ami arra utal, hogy a DNS replikáció gyakran a „piros” kromatinban kezdődik. A DNS kötő faktorok az egyes kromatin típusok által meghatározott 
módon kötődnek a felismerési szekvenciájukhoz. Minden kromatin típus specifikus DNS kötő faktorok DNS kötését segíti elő és specifikus régiókhoz irányítják azokat a genomon. ${ }^{39}$

A hiszton módosítások közül a lizin $\varepsilon$-aminocsoportjának acetilációja az elsőként felismert hiszton módosítások közé tartozik. ${ }^{51}$ A hisztonok acetilációja a gén aktivációval mutat korrelációt. A lizin acetiláció az egyik leggyakoribb fehérje poszttranszlációs módosítás, amely szabályozza a fehérjék affinitását más fehérjékhez. ${ }^{52}$ Ezeket a jelöléseket bromodomént tartalmazó kromatin-asszociált fehérjék ismerik fel. ${ }^{53} 545556$ Az acetilációt hiszton acetiltranszferáz (HAT) enzimek hozzák létre és hiszton deacetilázok képesek (HDAC) eltávolítani (2. ábra). ${ }^{57} \mathrm{Ez}$ egy nagyon dinamikus folyamat, amely fontos szerepet tölt be a kromatin átrendeződés és a transzkripció irányításában. 58596061

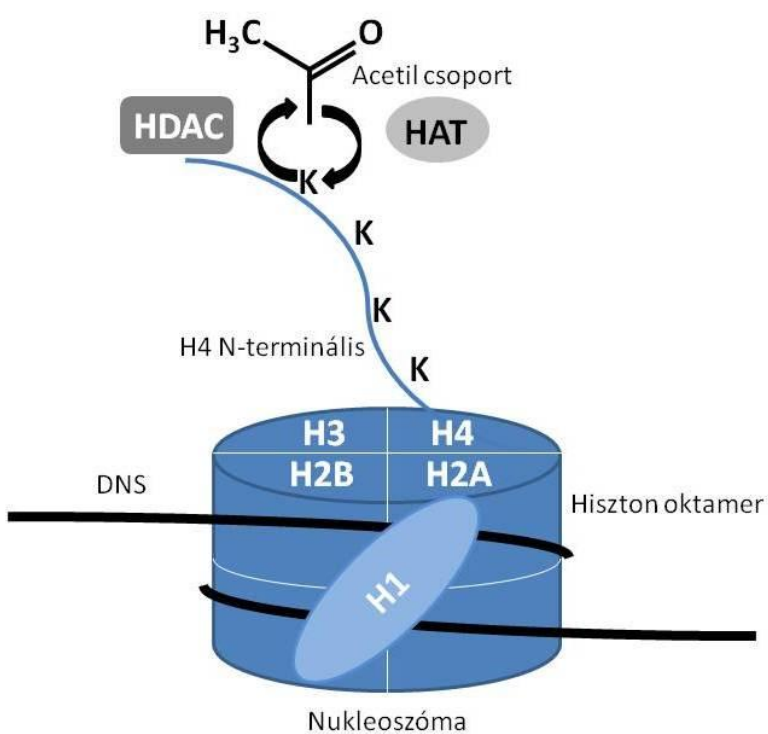

2. ábra. Hiszton fehérjék acetilációja. Az acetiláció egy dinamikus folyamat a sejtekben, amely specifikus lizin aminosavakon jön létre. Kialakítását HAT, eltávolítását HDAC enzimek végzik.

A hiszton acetiltranszferázok acetil-CoA-ról acetil csoportot helyeznek a hiszton fehérjék specifikus lizin aminosavaira. Az acetilcsoport thioészterről aminra helyezése viszonylag alacsony kémiai „költséggel” jár, az olyan kémiai reakciókhoz képest, mint például a foszforiláció. ${ }^{62}$ A hiszton peptid szubsztrátok az enzimek központi core régiója által kialakított árokhoz és a szomszédos részeken található amino- és karboxi-terminális részekhez kötődnek, itt jön létre a kölcsönhatások többsége. ${ }^{62}$ Azonban a hiszton acetiltranszferázok a hisztonok mellett számos nem-hiszton fehérje szubsztrát acetilálására is képesek (pl. AML1, AML1-ETO, p53, c-MYC, NF-кB, Cohesin, Tubulin). ${ }^{63646566676869}$ A hiszton fehérjék acetilációja nyitottabb kromatin szerkezetet eredményez, ami lehetővé teszi a transzkripciós faktorok számára a hozzáférést a DNS-hez. Celluláris lokalizációjuk alapján a HAT enzimeket A és B típusra osztják. Az A típusú hiszton acetiltranszferázok nukleáris lokalizációt mutatnak és transzkripcióhoz kapcsolódó folyamatokat szabályoznak. ${ }^{70} \mathrm{Ez} \mathrm{a}$ típus további öt alosztályra osztható homológiájuk és acetilációs mechanizmusuk alapján. ${ }^{61} \mathrm{~A}$ 
GNAT család tagjai közé tartozik a PCAF, a Gen5 és az ALP3. A CBP és p300 alkotja a CBP/p300 családot. ${ }^{71}$ A Tip60, MOZ, MORF, HBO1 és HMOF a MYST család tagjai. ${ }^{72}$ A transzkripciós faktorokkal kapcsolatban álló HAT családba tartozik a TAF1 és a TIFIIIC90. Továbbá számos szteroid receptor koaktivátor is tartozik a HAT enzimek közé, ilyenek a p600, SRC1, CLOCK és AIB1/ACTR/SCR3. ${ }^{73} 74$ A B típusú hiszton acetiltranszferázok citoplazmatikus lokalizációt mutatnak és az újonnan szintetizálódó hiszton fehérjéket acetilálják. Ilyen enzim a Hat1, amely részt vesz a DNS hibajavításban és a hiszton depozícióban is. ${ }^{75}$

A hiszton acetiltranszferázok aktivitását szabályozhatják szabályozó fehérje alegységek vagy autoacetiláció. Számos hiszton acetiltranszferáz multiprotein komplexekkel müködik együtt azok katalítikus aktivitását vagy szubsztrát specifitását szabályozva. ${ }^{76} 77$ Továbbá számos HAT katalítikus aktivitásához szükséges valamilyen kofaktor kötése. ${ }^{62}$

A bromodomének családja egy olyan fehérje domén család, amely képes felismerni az acetilált lizineket. A lizin acetiláció reverzibilis természetének köszönhetően az acetil-lizin és bromodomén kölcsönhatás dinamikus és tranziens a sejtekben. ${ }^{56}$ A konzervált strukturális felépítés ellenére a bromodomén család teljes szekvencia hasonlósága nem magas. A bromodomének magukba foglalnak egy konzervált, négy hélixböl felépülő balmenetes köteget $\left(\alpha_{Z}, \alpha_{A}, \alpha_{B}, \alpha_{C}\right)$, egy inter-helikális ZA és BC hurokkal, melynek hossza és szekvenciája variábilis. ${ }^{78} \mathrm{Az}$ acetil-lizin felismerése a ZA és BC hurok közötti hidrofób zsebbel történik. ${ }^{79} \mathrm{~A} \mathrm{BC}$ hurok kezdeti részén egy magasan konzervált aszparagin aminosav alakít ki hidrogén kötést az acetil-lizin karboxil oxigénjével oldalláncának amid nitrogénjén keresztül. ${ }^{62}$

Kísérletesen az acetiláció hatásai olyan pontmutánsokkal vizsgálhatóak, ahol a lizin (K) aminosav glutaminra $(Q)$ cserélése acetilációt mimikál, míg a lizin-arginin (K-R) csere acetilálatlan (vagy módosítatlan) lizint mimikáló szubsztitúció. ${ }^{80} 81$

\section{I.4. A hiszton fehérjék útja a sejtmagba}

Az újonnan szintetizált kanonikus és variáns hisztonok, valamint a reciklizált hisztonok áthelyezésre kerülhetnek a DNS-re replikációt, transzkripciót, DNS hibajavítást vagy más nukleáris folyamatot követően. A hiszton depozícióban a hiszton chaperon fehérjék játszanak szerepet. Funkcióik közé tartozik a hiszton folding elősegítése ${ }^{82}{ }^{83}$, a hiszton-enzim kölcsönhatás kialakulásának elősegítése ${ }^{83} 848586$, a szolubilis hiszton pool fenntartása ${ }^{87} 88$, hisztonoknak a DNS-re helyezése ${ }^{89}$, hiszton kicserélés elősegítése 909192 .

A hiszton chaperonok savas felületekkel tudnak a hisztonokhoz kötődni és gyakran tartalmaznak helyettes vagy kiegészítő fehérje doméneket a hisztonokkal való kölcsönhatáshoz. Ilyenek például a TPR (tetratricopeptide repeats) motívumok a NASP (nuclear autoantigenic sperm protein) fehérjében ${ }^{93}$, az RbAp46/48 fehérje WD40 doménje ${ }^{94}$ 95 és az ASF1 (antisilencing factor 1) IgG-szerü régiója ${ }^{96} 97$.

Az újonnan szintetizált hisztonok különféle módosításokon esnek át a megfelelő nukleáris transzporthoz. ${ }^{98}$ A misfolding és aggregáció elkerülése érdekében számos fehérje chaperon gyülekezik a riboszómális polipeptid exit helyek mellett. A Heat Shock Protein 70 fehérje 
család tagjai ezekhez a helyekhez toborzódnak, hogy ATP-t felhasználva kialakítsák a fehérjékben a hidrofób szegmenseket. ${ }^{98}$ A H3 és H4 külön hősokk fehérjékkel létesít kapcsolatot, a Hsc70-el (Complex Ia) és a Hsp70/90 (Complex Ib) komplexszel. Ezt követöen a tNASP hiszton chaperon és a Hsp90 (Complex II) közremüködésével a H3 és H4 egy heterodimert hoz létre. Az elsőként detektálható poszt-transzlációs módosítás már a transzláció során megjelenik, mikor a $\mathrm{H} 3$ még a riboszómához kapcsolódik. Ez a H3K9 metiláció, amelyet humán sejtekben a SetDB1 (SET domain, Bifurcated 1) enzim hoz létre. ${ }^{99}$ Az újonnan szintetizált hiperacetilálódott hisztonok kevésbé stabilak és hibás kapcsolatot alakítanak ki a Hsp chaperonokkal, ami a sejtciklus folyamatára is hatással van. Ezért az INHAT (inhibitor of acetyltransferases) fehérje komplex szabályozza az újonnan szintetizált H4 hisztonok megfelelő acetiláltsági állapotát. ${ }^{100}$ A humán sejtekben a H3-H4 dimeren megjelenik a H3K14 és K18 acetiláció ${ }^{101}{ }^{102}$, majd H3-H4 dimer kapcsolódik az ASF1 (antisilencing function 1) és sNASP (somatic nuclear autoantigenic sperm protein) hiszton chaperonokhoz, valamint a Hat1 (histone acetyltransferase 1) enzimhez (Complex III). A Complex III-ban a H4 már nincsen kölcsönhatásban az INHAT alegységekkel, helyettük a Hat1 enzimmel kerül kapcsolatba, amely acetilálja a H4K5 és K12 pozíciókat. ${ }^{100}$ Végül a H3H4 hisztonok kölcsönhatnak az Importin-4-el és az ASF1-el (Complex IV), így jutnak be a sejtmagba a kromatinba rendeződéshez. ${ }^{82} 83$

A 40 kDa-nál nagyobb méretű makromolekulák nem tudnak egyszerü diffúzióval átjutni a nukleáris pórus komplexen, ezért aktív transzporterek segítségére van szükségük, melyeket karyopherinnek (Kap) vagy importinnak (Imp) neveznek ${ }^{103}$. A karyopherin fehérje család NLS (nuclear localisation signal) szekvenciát vagy nukleáris export szignált ismer fel a cargo fehérjék importjához vagy exportjához ${ }^{104} 105$ 106. Az NLS szekvencia egy strukturálisan rendezetlen régió, ami főként pozitív töltésü aminosavakból áll limitált szekvencia homológiával. ${ }^{107}$ Az NLS szekvenciák közötti konzerváltság hiánya kicsiny számú Kap fehérje számára teszi lehetővé nagy számú nukleáris fehérje transzlokációját a nukleuszba, vagyis egy egyszerü Kap fehérje számos szubsztrátot képes transzlokálni ${ }^{108}$.

Az ASF1-H3-H4 komplexhez kötődö számos karyopherin fehérje közül az Importin 4/Kap123 (humán/élesztő) a legáltalánosabb (Complex IV), amely arra enged következtetni, hogy ez az elsődleges nukleáris importere. ${ }^{82} 83101109$ A karyopherinek közvetlenül kötődnek a hiszton farki részekhez azok NLS-szerü szekvenciáján keresztül ${ }^{110}$, de az Importin-4 a teljes ASF1-H3-H4 protein komplexet ismeri fel. ${ }^{111}$ A Kap123 két lizin-kötő zsebet használ a H3 ${ }_{1-28}$-NLS felismerésére és megkötésére. A H3K14 és K23 a kulcs aminosavak a Kap123 kötődésben és az acetiláció zavarja ezt a kölcsönhatást. A H4 $4_{1-32}$-NLS-t a Kap123 valószínüleg a második lizin-kötő zsebén keresztül köti meg és a felismerés a H4K16-on keresztül történik meg. A H4K16 acetiláció valamint a Hat1 által létrehozott H4K5K12 diacetiláció szintén csökkenti az importin kötést. A H4K5K12 diacetiláció támogatja a H3Kap123 kötődést, így az ASF1-H3-H4 nukleáris import a H3 NLS szekvencián keresztül valósul meg. ${ }^{112}$ Az ASF1 destabilizálja az Importin-4-hiszton kölcsönhatást, azt sugallva, hogy közreműködik a hiszton-felszabadításban a nukleuszban. A karyopherinek egy magi RAN GTPázt használnak a teljes disszociációhoz az ASF1-H3-H4-ről a nukleuszban. ${ }^{113} 114$

A H2A/H2B dimeren nem figyelhető meg poszt-transzlációs módosítás a nukleáris import előtt. A H2A/H2B dimer hiszton chaperone-okkal lép kölcsönhatásba a citoplazmában, pl. a 
Nap-1-gyel, amely elősegíti a nukleuszba jutását, a H3/H4 tetramerekkel történő kölcsönhatását és a nukleoszómák kialakítását. ${ }^{115} 116$

Replikáció során az eredeti templát DNS szálról származó nukleoszómákat alkotó parentális hiszton fehérjék közvetlenül a replikálódó DNS-re helyeződnek és újra összerendeződnek nukleoszómákká. ${ }^{117}$ A szolubilis hiszton fehérjék, melyek az osztódó sejt $\mathrm{S}$ fázisa során szintetizálódtak szintén nukleoszómába rendeződnek az új DNS szálra. Ezt a folyamatot kromatin összerendező faktorok segítik elő. ${ }^{118}$

A CAF-1 (Chromatin assembly factor 1) egy kromatin összerendező faktor, amely részt vesz az újonnan szintetizálódott hisztonok depozíciójában. ${ }^{119}{ }^{120} \mathrm{Ez}$ a fehérje komplex a p150, p60 és az RbAp48 (vagy élesztőben a Cac1, Cac2 és Cac3) alegységekből áll ${ }^{120}{ }^{121}$, és a replikációs villák mögött van jelen, ugyanis kölcsönhat a PCNA (proliferating cell nuclear antigen) processzáló gyürüvel ${ }^{122}$. Az RbAp48 CAF-1 fehérje alegység kölcsönhat a H4 hisztonnal ${ }^{94} 95$ és hiánya a nukleoszóma összerendeződés hibáihoz vezet in vitro. ${ }^{123}$ Egyes tanulmányok egy olyan modellt sugallnak, ahol két CAF-1-H3-H4 komplex egy (H3-H4) tetramerré rendeződik a DNS-en. ${ }^{124} 125$ A nukleoszómális hisztonok feltételezhetően a DNS replikáció során bekövetkező DNS looping során helyeződnek át. ${ }^{126}{ }^{127}$ Míg a DNS looping talán a hisztonok szegregációjában játszik szerepet a replikációs villáknál, az eukarióta replikatív helikáz képes kapcsolatba lépni a hisztonokkal 128129130131 és ez elkülöníti a szülői hisztonokat, közel tartva azokat az eukarióta replikációs gépezethez ${ }^{132} 133$.

A H2A/H2B dimerek kölcsönhatását a H3/H4 tetramerrel elősegíti egy konzervált acetilációs módosítás is a H4K91 pozícióban, amelyet a Hat4 enzim hoz létre, szabályozva a hiszton oktamer összerendeződést és a tetramer-dimer kölcsönhatás stabilitását. 134135136137

\section{I.5. A Hat1 hiszton acetiltranszferáz}

A Hatl egy B típusú hiszton acetiltranszferáz. A B típusú hiszton acetiltranszferázok az újonnan szintetizálódott hiszton fehérjéket acetilálják kromatinba épülésük előtt. 138139140141 $142143144145 \mathrm{Ez}$ a fajta acetilációs tevékenység többnyire a H3 és H4 hiszton fehérjéken érvényesül közvetlenül a szintézisüket követően. ${ }^{146} 147148$ A hiszton fehérjék nukleoszómába épülését követően a kromatin érés folyamata során ezek a módosítások eltávolításra kerülnek. 148149 A H4 hiszton acetiláltsági mintázata nagymértékű konzerváltságot mutat az eukarióta élőlényekben. A H4 potenciálisan acetilálható lizin $(\mathrm{K})$ aminosavai az N-termiláis farki részén található 5-ös, 8-as, 12-es és 16-os pozíciók. Ezek közül az újonnan szintetizált hisztonokon a K5 és K12 acetiláltsága megfigyelhető volt a legtöbb vizsgált eukariótában, a K8 és K16 pedig nem. ${ }^{150} 151152$ Az újonnan szintetizálódott H3 hiszton fehérjék acetilációs mintázata ennél jóval nagyobb varianciát mutat a különböző organizmusokban. 151153154

A Hat1, mint azt neve is sejteti, az elsőként felfedezett hiszton acetiltranszferáz enzim. ${ }^{155}$ Főként a citoplazmában található meg, azonban a nukleuszban is jelen van. ${ }^{85}$ A Hat1 gén felfedezése két különböző úton történt. Az első ilyen kísérletben hőérzékeny élesztő mutánsok vizsgálatát végezték, hogy azonosítsanak egy olyan törzset, amely H4 hiszton acetiláció defektust mutat. Az alacsonyabb hiszton acetiltranszferáz szintet a XVI. kromoszóma jobb karjának centormer közeli régiójában található Hatl mutáció okozta. ${ }^{155}$ A második ilyen 
kísérlet is élesztőben történt, ahol a citoplazmatikus H4 acetilációért felelös hiszton acetiltranszferázt akarták izolálni. A tisztítást követően a katalítikus alegység fehérje szekvencia adatai lehetővé tették a hozzá tartozó gén azonosítását. Az élesztő extraktumból a Hatl együtt tisztult egy másik polipeptiddel, a Hat2-vel, amely növelte a Hat1 katalítikus aktivitását. ${ }^{85}$

Számos más organizmusból tisztítottak azóta H4 specifikus B típusú hiszton acetiltranszferázt. Ezek nagymértékű evolúciós konzerváltságot mutattak és gyakran együtt voltak tisztíthatóak egy Hat2-höz hasonló WD-40 domént tartalmazó fehérje alegységgel, pl. X. laevis (Rbap48), csirke és humán (Rbap46) minták, valamint kukorica esetén is. ${ }^{15615786158}$ 159160161 Az RbAp46 fehérje WD-40 doménje a H4 hiszton első alpha hélixéhez kötődik és megváltoztatja a hiszton fold domén térszerkezetét. ${ }^{162} 95$ Ez a konformációs változás a Hat1 katalítikus alegységét a hiszton farki rész közelébe helyezi ${ }^{85}$, így az RbAp46 H4 hisztonhoz kötődése nagymértékben megemeli a Hat1 katalítikus aktivitását. 859586

Számos eukarióta sejt lízise során a Hatl enzim a szolubilis citoplazmatikus frakcióban volt megtalálható és a szabad H4 fehérjéken mutatott aktivitást, így sokáig azt feltételezték, hogy nagyrészt vagy teljes mértékben a citoplazmára korlátozódik acetilációs tevékenysége. ${ }^{85}$ Azonban sikerült a nukleuszban is kimutatni a jelenlétét. ${ }^{163}$ A Hat1 citoplazmatikus aktivitására élesztőben, $X$. laevisben és emberben a H4 hiszton K5 és K12 acetilálása jellemző, azonban emberben mutat némi H2A K5 acetilációs aktivitást is. ${ }^{85} 155$

Szintetikus peptidekkel végzett kísérletekkel kimutatták, hogy a 8-as és 16-os lizinek acetiláltsága esetén a Hat1 nem képes módosítást végezni a fehérjén. A 8-as és 16-os lizin argininre (acetilálatan állapotot mimikáló módosítás) cserélése esetén azonban a Hat1 képes funkcióját betölteni, vagyis ezen pozíciók pozitív töltése a fontos. ${ }^{164}$ Több proteomikai tanulmány alapján a Hat1/Rbap46 komplex elsődleges kölcsönható partnerei a szolubilis H3/H4 komplexeknek. ${ }^{83} 82 \quad 165166167168169109170113$ Érdekes módon különböző modell rendszerekben, a gombáktól egészen az emlös sejtekig, a Hatl mutációk különféle fenotípusokban nyilvánultak meg.

Gombákban kimutatták, hogy szerepe van a H4 hiszton nukleáris importjában. Candida albicansban a Hat1 a H4 hisztonhoz kapcsolódik és acetilálja azt a nukleáris transzlokációt megelőzően, továbbá a nukleáris importban részt vevő NuB4 komplex tagjaként is jelen van. ${ }^{171}$ Physarium polycephalumban a H4 K5 és K12 acetilációt gátló mutációk a nukleáris import hibáihoz vezettek. ${ }^{171}$

Gombában és emlős sejtekben azt a felfedezést tették, hogy a Hat1 részt vesz a kromatin összerendeződésben is. Physarium polycephalumban részt vesz az újonnan szintetizálódott H3/H4 replikációs helyhez való szállításában és a H4 hiszton fehérje replikáció kapcsolt acetilációja szükséges a hatékony kromatin összerendeződéshez. ${ }^{171}$ Egér embrionális fibroblaszt (MEF) sejtekben kimutatták, hogy a Hat1 szükséges a H4 K5 és K12 acetilációjához a replikáció kapcsolt kromatin összerendeződés és a megfelelő kromatin konformáció fenntartása során. A Hat1 hiánya a bromodomént tartalmazó fehérjék - Brg1, Baz1a, Brd3 - csökkenéséhez, valamint a Topoizomeráz 2 és a DNS helikázok szintjének növekedéséhez vezet MEF sejtekben. ${ }^{172}$ A MEF sejtekben Hat1 hiánya esetén a transzláció regulációért, mRNS splicingért és DNS hibajavításért felelős fehérjék dúsulása is 
megfigyelhető volt a naszcens kromatinon, míg a DNS replikációban részt vevő faktorok nagyrészt változatlan mennyiségben fordultak elő. Hat1 deléció hatására számos ATP-függő kromatin átrendezö komplex (Brg1, NuRD, ACF) is csökkent szintet mutatott a naszcens kromatinon, ami megváltozott struktúrára utal. Mindemellett a core hisztonok és hiszton chaperonok (FACT komplex, ATRX, NMP3) száma is megemelkedett Hat1 hiányában. A Hatl úgy tünik, hogy a kromatin érés idején disszociál a naszcens kromatinról, amely után bekövetkezik a H4K5K12 deacetiláció. ${ }^{172}$

A Hatl egy további különleges szabályozó szerepére lettek figyelmesek Xenophus, Drosophila, csirke és humán sejtekben egyaránt, ami nem más, mint a CENP-A centromerikus H3 hiszton variáns fehérje megfelelő kromatinba építése. Xenophus pete extraktumban az RbAp46/48 - Hat1 komplex specifikusan köt a CENP-A N-terminális

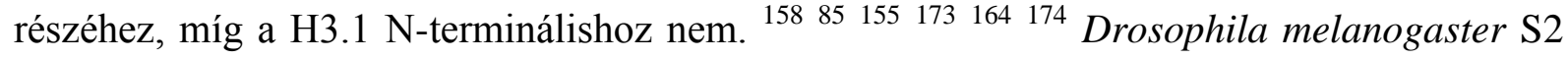
sejtekben a Hat1 stabil komplexet hoz létre a CENP-A-val a nukleuszban és a citoplazmában is. A Hat1 nem módosítja a CENP-A aminosavait, hanem kölcsönhatásba lép a CENP-A - H4 dimerrel és a H4-es hisztont acetilálja a K5-ös és K12-es pozícióban. A kölcsönhatás fennmarad a kromatinba épülésig, ami egy chaperon-szerü funkciót sejtet és talán a H4 hiszton acetilált állapotát hivatott fenntartani. A Hat1 komplex megtalálható citoplazmatikusan, nukleárisan és kromatinhoz kötött állapotban is a sejtben. Hat1 hiányában csökkent CENP-A centromerikus kromatinba épülés volt megfigyelhető. ${ }^{175}$ Az acetilálatlan H4 a CENP-A-val nem épült be a centromerikus régióba Xenopusban és csirke DT40 sejtekben sem. ${ }^{176} 177178$ DT40 csirke és humán HeLa sejtekben a H4K5 és H4K12 acetilációs jelek dúsulását figyelték meg a centromer régiókon. RbAp48 deficiens és mutáns (Y32H) DT40 sejtekben a prenukleoszómális CENP-A-H4 komplexekben a H4K5ac és H4K12ac szint, valamint a centromerek CENP-A szintje kevesebb, mint felére csökkent ${ }^{178}$ Acetilálatlan lizineket mimikáló H4-K5RK12R fehérje expressziójának hatására a CENP-A nem centromerikus régiókba történő hibás beépülése az RbAp48 mutáns sejtekéhez volt hasonló. A H4-K5RK12R expresszió következtében kialakuló hibás CENP-A beépülés arra utal, hogy az RbAp48-Hat1 komplex általi acetiláció szükséges a H4 - CENP-A komplex centormerbe épüléséhez. Acetilált lizineket mimikáló H4-K5QK12Q expresszió hatására a centromerikus CENP-A szint növekedett az RbAp48 deficiens sejtekben, vagyis az acetilációt mimikáló H4 menekítette a hibás CENP-A beépülést. ${ }^{178}$

Élesztőben, továbbá csirke és egér sejtekben felfedezték, hogy a Hat1 hiánya DNS repair hibákat és megnövekedett érzékenységet okoz a DNS károsító ágensekkel szemben. Schizosaccharomyces pombe-ban a Hatl deléciója érzékenyebbé teszi az élesztőt az MMS DNS károsító szerre. ${ }^{173}$ Candida albicans-ban a DNS különböző hibáinak javítása sérül és a DNS sérülések száma is gyakoribb. Emellett a deléciós mutánsok lassabb növekedési fenotípust is mutattak. ${ }^{171}$ Csirke DT40 sejtekkel végzett kísérletekben a Hat1 hiánya szintén lassabb növekedést és megemelkedett érzékenységet eredményezett MMS és camptotechin kezelés hatására. ${ }^{165}$ Egerekben a Hatl deléciója neonatális letalitást okozott és a Hatl null mutáns egerekből származó egér embrionális fibroblaszt sejtekben növekedési defektusok, genom instabilitás, valamint megemelkedett érzékenység volt megfigyelhető a DNS károsító anyagokkal szemben. Ezek a sejtek emelkedett szenzitivitást mutattak mind az egyes szálú, mind a kettős szálú DNS törést okozó anyagok hatására. ${ }^{179}$ Saccharomyces cerevisiae-ben 
csak akkor voltak megfigyelhetőek ezek a DNS hibajavítási zavarok, ha a mutációt kombinálták lizin-arginin cserékkel a H3-as hiszton N-terminális részén. ${ }^{180} 181$

Élesztőben felfedezték azt is, hogy a Hat1 szerepet játszik a telomerikus csendesítésben. Saccharomyces cerevisiae-ben, mikor a Hatl mutációt kombinálták lizin-arginin cserékkel a $\mathrm{H} 3$-as hiszton $\mathrm{N}$-terminális részén, az telomerikus csendesítési hibákhoz is vezetett. ${ }^{180}{ }^{181} \mathrm{Ha}$ a H3 N-terminális módosításokat kombinálták H4 N-terminálison található lizinek argininre cserélésével, azt kapták, hogy egyedül a H4K12-es pozíció esetén (a K5, K8, K16-nál nem) tapasztaltak hasonló telomerikus csendesítési hibákat, tehát a Hat1 hatása a 12-es pozíción keresztül érvényesülhet. ${ }^{180}$

\section{I.6. Epigenetikai változások a neurodegeneratív betegségekben}

A neuronok olyan dinamikus sejtek, amelyek hosszú posztmitotikus életük során válaszolnak, reagálnak az őket érő ingerekre. Strukturális és funkcionális plaszticitásuk megfelelö transzkripció regulációt igényel, ugyanis ennek nem megfelelő müködése a fejlődő és adult agyban egyaránt a kognitív funkciók meghibásodásához vezet. ${ }^{182}$

A leggyakoribb neurodegeneratív betegségek esetében a legjelentősebb kockázati tényezőt az öregedés jelenti, amely összefüggésben áll a kognitív kapacitás csökkenésével is. Ezek a betegségek a neuronok progresszív degenerációját, sejtpusztulást okoznak, és többségükre nem ismerünk gyógymódot. A legismertebb neurodegeneratív betegségek közé tartozik az Alzheimer-kór, a Parkinson-kór, az amiotrófikus laterálszklerózis, a frontotemporális

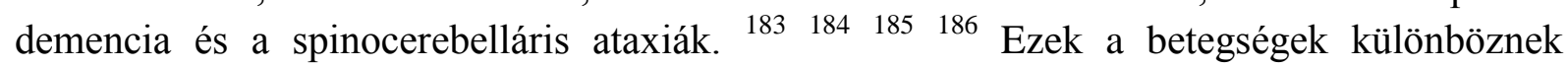
pathofiziológiájukban, némely közülük a memóriát érinti és kognitív zavarokat okoz (pl. Alzheimer-kór), mások a mozgást érintik (pl. ataxiák) és vannak, melyek mindkettőt (pl. Parkinson-kór). ${ }^{187}$

Ismertek olyan neurodegenratív megbetegedések, amelyeket egyetlen gén mutációja vált ki. Azokat a megbetegedéseket, ahol egy fehérjében meghosszabbodott glutamin szakasz jelenik meg CAG trinukleotid ismétlődések átíródása következtében, poliglutamin betegségeknek nevezik. Attól függően, hogy milyen génben keletkezik a hiba és milyen sejteket érint, különböző kórképeket okozhat. Ilyen megbetegedés a Huntington-kór (HD), a spinális bulbáris izomatrófia (SBMA), a dentatorubral-pallidoluysian atrófia (DRPLA) és a spinocerebelláris ataxia (SCA) hat formája. Ezen betegségek pathomechanizmusának közös vonása, hogy a képződött fehérje poliglutamin szakasza miatt megváltozik a kódolt fehérjék térbeli szerkezete és aggregációra hajlamossá válnak. ${ }^{188}$ Úgynevezett fehérje aggregátumok keletkeznek, melyek struktúrálisan károsítják a sejteket, továbbá toxikus fehérje fragmentumok hasadnak le belölük, amelyek a sejtmagba vándorolva a DNS expresszióját megváltoztatják és más proteinekhez kötődve megváltoznak a fehérje-fehérje kölcsönhatások is a sejten belül. Ez elsősorban a neuronális sejteket érinti. A repeat instabilitás kialakulásának pontos okát nem ismerjük. A DNS replikációja során keletkező szál-törések javításakor a DNS polimeráz enzim „elcsúszása” az ismétlődő szekvenciáknál eredményezhet expanziót és a hiba kijavításában résztvevő mismatch repair rendszer funkciózavara is hozzájárulhat a mutáció létrejöttéhez. ${ }^{188} 189190191192193$ 
Számos tanulmány világított már rá, hogy milyen kritikus funkciót tölt be a kromatin és az epigenetikai szabályozás az agy öregedése, illetve a neurodegeneráció során. Neurodegeneratív betegségeknél megfigyelhetőek epigenetikai szabályozásbeli eltérések az egészséges öregedő agyhoz képest. ${ }^{194} 195$ Egyes hiszton acetilációs és metilációs szint változások korhoz köthetőek. Állatmodellekben az öregedés során a represszív jelek H3K9me2, H3K9me3 és H3K27me3 - szintjében csökkenés következik be, illetve az aktiváló hatású jelek - H3K36me3 és H3K27ac - mennyisége megemelkedik a cerebrális kortexben és a hippokampuszban. ${ }^{196}$ A különböző kromatin-asszociált faktorokban bekövetkező mutációk olyan neurológiai betegségekhez vezetnek, mint például az autizmus spektrum betegségek (pl. MECP2) ${ }^{197} 198$, a mentális retardáció (pl. FMRP) ${ }^{199}$ és a skizofrénia (pl. CHD2) ${ }^{200}$.

Elözetes vizsgálatok azonosítottak közös DNS metilációs változásokat különböző neurodegeneratív betegségeknél, ami közös szabályozási programot feltételez. ${ }^{201}$ Az olyan neurodegeneratív betegségek, mint az Alzheimer-kór, Huntington-kór és az amiotrófiás laterálszklerózis, nagymértékü transzkripciós profil változással hozhatóak kapcsolatba, ami a kromatin szabályozás érintettségére utal. ${ }^{202} 203204$ Mindez rávilágít arra, hogy milyen fontos szerepet tölt be az epigenetikai szabályozás az idegsejtek müködésében és az idegrendszeri funkciókban.

\section{I.7. A Huntington-kór}

A Huntington-kórt (Huntington's disease, HD) 1872-ben George Huntington írta le először, mint önálló betegséget. A betegség kialakulásáért felelös génhibát 1993-ban fedezte fel a Huntington's Disease Collaboration Research Group. ${ }^{205}$ A Huntingtin gén $210 \mathrm{~kb}$ hosszúságú, 67 exont tartalmaz. Az első exonban az open reading frame-en belül van egy instabil, polimorf CAG trinukleotid ismétlődés, melynek expanziója úgynevezett funkciónyeréses (gain of function) mutációhoz vezet. Egészséges személyeknél a CAG ismétlődések száma 9-36 között váltakozik. Mutáció következtében a CAG ismétlődések száma 36-121 érték közé emelkedik, ami megváltoztatja a kódolt fehérje funkcióját. Minél hosszabb az ismétlődések száma, annál gyorsabb és súlyosabb lefolyású a betegség. ${ }^{206} 207$ A nagy méretű Huntingtin (Htt) fehérje föként a citoplazmában található meg, a mutáns formáknál azonban hibás proteolítikus hasítások következtében olyan N-terminális fragmentumok keletkeznek, melyek bejutnak a sejtmagba. ${ }^{207} 208$

A betegség egy autoszómális domináns módon öröklődő progresszív neurodegeneratív kór. Tünetei általában 40-45 éves kor között jelentkeznek és 10-15 éven belül halálhoz vezetnek. Három fó tünetcsoport jellemzi: motoros tünetek, pszichopathológiai zavarok és kognitív hanyatlás. Jellemző motoros tünet a chorea, amely spontán jelentkező irreguláris mozgás. Súlyosan károsítja a beteg mozgását, járása lassú, merev, bizonytalan. A betegség végstádiumában a korábbi hiperkinézist bradikinézia, rigiditás és disztónia váltja fel. A kognitív hanyatlás már a betegség korai szakaszában észlelhető. Ennek a frontális típusú demenciának a fö tünetei a memóriazavar, lelassult információfeldolgozás és kognitív inflexibilitás. Jellemző továbbá a személyiségváltozás: gyanakvó, paranoid, impulzív viselkedés kialakulása figyelhető meg a betegeknél. Csökken az önkontroll, dühkitörések, aggresszivitás jelentkezhet. Gyakori a depresszió, alkoholizmus, öngyilkosság. A klinikai 
tünetek neuropathológiai alapja a nucleus caudatus és az agykéreg sorvadása. A striatális degeneráció foka korrelál a motoros és pszichés tünetek súlyosságával. A striátum sejtjei közül föként a közepes méretü tüskés neuronok érintettek, melyek efferenseket küldenek a globus pallidusba és a substantia nigrába. 209210211212213214

A vad típusú Huntingtin fehérje egy scaffold-szerü funkciót betöltve számos fehérje komplexszel lép kölcsönhatásba, melyek különbözö celluláris folyamatokban vesznek részt. 215216217218219 A Htt fehérje kölcsönhat számos olyan transzkripciós faktorral is, amelyek a neuronális túlélést szabályozó gének expressziós aktivitásában játszanak szerepet. ${ }^{220} 221222207$ Funkciója van továbbá az endo-exocitózis szabályozásában, az endo-exocitotikus és recycling rendszer elemeivel való kölcsönhatás révén. ${ }^{223} 224$ Így mintegy anti-apoptotikus faktorként, részt vesz a szinaptikus transzmisszió és az agyi homeosztázis regulációjában, valamint a sejt érés és differenciáció folyamatának szabályozásában is. ${ }^{216} 218225226$ A Htt kölcsönhatásba lép a dinein és a kinezin molekuláris motor komplexekkel is. ${ }^{227} 228$ A Huntingtin fehérje mennyiségének csökkenése a dinein/dinaktin komplex nem megfelelő működését okozza, ami az axonális transzport csökkenéséhez vezet és hatással van az osztódási orsó helyzetére a neuronális progenitor sejtekben. ${ }^{229} 230227225$ A megfelelő orsó orientációra a neuroepitheliális őssejtek osztódása során kritikus szükség van. ${ }^{231}$ A Htt mennyiségének csökkenése a ciliogenezisben is csökkenést okoz. ${ }^{226}$ Tanulmányok tesznek említést arról is, hogy a vad típusú Huntingtin fehérje a szelektív autofágia folyamatában is részt vehet. ${ }^{232} 233$ Drosophilában a Htt hiánya csökkent autofagoszóma kialakulást és emelkedett ubikvitinált fehérje mennyiséget eredményez. ${ }^{234}$

A Huntingtin mutáció következményeként fellépő neuronális sejthalált hosszú neuronális diszfunkció előzi meg, melyhez számos celluláris folyamat járulhat hozzá. Ilyen sejten belüli folyamatok a mutáns Huntingtin ( $\mathrm{mHtt}$ ) fehérje hasításon és aggregáción túl a hibás fehérjefehérje kölcsönhatások, a funkcióképtelen kalcium szignalizáció, az abnormális axonális transzport, a károsodott metabolizmus, a neuronális aktivitás diszregulációja és a megváltozott transzkripciós aktivitás. ${ }^{207} 218235236$ A transzkripcionális diszreguláció központi szerepet játszik a Huntington-kór pathogenezisében. ${ }^{237}$ A fó transzkripcionális változások az agyban detektálhatóak a betegség hatására. ${ }^{202}$

Egér modellen kimutatták, hogy a Htt gén hibája esetén számos gén mutat megváltozott expressziót az egészséges egyedekhez képest. A downregulált gének között megtalálhatóak olyan gének, amelyek a striatális neuron identitásért és funkciókért felelősek, úgymint a Darpp32, az Rgs9, a Drdl és a Drd2. 202238239240241 Kevesebb olyan gén mutatott downregulációt, amely a kortex neuronális jelátvitelében és szöveti identitásának kialakításában vesz részt. ${ }^{239}{ }^{241}$ HD mutáns sejtekben REST, SP1, TAF130, p53 transzkripciós faktorok deregulációja is megfigyelhető az abnormális fehérje interakciók miatt. 242243244218 245241 A neuronális aktivitásban, plaszticitásban és ingerelhetőségben kulcsfontosságú szerepet játszó IEG (Immediate Early Gene) faktorok, mint pl. a Fos, Egrl, Arc, dinamikus expresszióját szabályozó szignalizációs útvonalak (cAMP, CREB/CBP, Ras/MAPK/MSK1) HD-s striátumban szintén hibásnak tünnek. ${ }^{246} 247248$ Huntington-kóros páciensek posztmortem prefrontális agykérgi mintáin végzett kísérletek azt mutatták, hogy a Hox gének és más homeobox gének reaktiválódtak a páciensek agyában és az egyedfejlődés során még éretlen neuronsejtekhez hasonló expressziót mutattak. Ezáltal a neuronális identitásért felelős 
transzkripciós program a HD-s páciensek agyában zavart szenved. A striátum és kortex upregulált génjei közé tartoznak a gyulladási (inflammációs) folyamatokban részt vevő gének is. 249202

A mHtt fehérje az olyan kromatin szabályozó faktorok aktivitását is érintette, mint a Polycomb repressive complex 2 (PRC2). A Htt hozzákötődik a PRC2-höz a sejtmagban, ami a PRC2 aktiválásához vezet, míg a mHtt tovább serkenti a PRC2 aktivitást sejt modellekben. ${ }^{250}$ A PRC2 inaktiváció a striatális neuronokban a neuronális differenciációban szerepet játszó transzkripciós faktorok reaktiválódását és a striatális identitásért felelős gének downregulációját eredményezi. A PRC2 csökkent aktivitása adult neuronokban a HD-s egerekre emlékeztető molekuláris, elektrofiziológiás és viselkedési fenotípusokhoz vezet, a PRC2 inaktivációból és a mHtt expresszióból származó transzkripcionális jelek a striátumban mutatnak hasonlóságokat. ${ }^{251}$

A Huntington-kórra jellemző, hogy a különböző hiszton módosítások is zavart szenvednek. A HD során megfigyelhető hiszton acetilációs zavarokat részben a CREB-binding protein (CBP) és a Pcaf hiszton acetiltranszferáz aktivitású fehérjék kötődése, mHtt aggregátumokba történő csapdázódása okozza. ${ }^{242} 252$ Drosophila és egér modellen kimutatták, hogy a hiszton deacetilázok (HDAC) gátlása jótékony hatást fejt ki a HD fenotípusra. ${ }^{252} 253254$ Preklinikai tanulmányok is bizonyítják a jótékony hatását az olyan széles spektrumú HDAC inhibítoroknak, mint a SAHA (suberoxylanilide hydroxamic acid), TSA (Trichostatin A), fenilbutirát, nátrium-butirát. ${ }^{255256257258259}$ A HDAC inhibítorok HD-s egerekben javítottak a neuropathológián és a motoros funkción. A HDAC4 inaktiválása egy transzkripció független mechanizmuson keresztül, a mHtt aggregáció folyamatára hatva javít a HD-s egerek neurodegenerációján. Ez azt sugallja, hogy a nem-hiszton fehérjék acetilációján keresztül is hathatnak a deacetiláz gátlószerek. ${ }^{260} \mathrm{~A}$ mHtt overexpresszió hatására egerekben nagymértékü változás következik be a hiszton acetilációban. ${ }^{261}$ Azonban általánosan a H2B, H3 és H4 globális acetilációs szintben nem található különbség a HD-s R6/2 egerek agyszövete és a kontroll egereké között. ${ }^{256} 258$ A HD-s egerek striátumában speciális génlókuszokon figyeltek meg H3 acetiláció csökkenést. Ilyen downregulált génpromóter volt a Drd2, a Penk1, az Actb és a Grin1. ${ }^{258}$ Megfigyeltek H3K9, H3K14 és H4K12 acetilációs változásokat is a striátumban, azonban ezek a változások csak néhány lókuszra korlátozódtak és gyenge korrelációt mutattak. ${ }^{262}{ }^{263}$ A H3K27 acetilációnak szintén szelektíven lecsökkent a szintje. Erös korrelációt fedeztek fel továbbá a csökkent H3K27ac, a csökkent RNS polimeráz II (RNAPII) és a gének downregulációja között. Az úgynevezett szuperenhanszerek, amelyek a sejttípus specifikus identitást és funkciót definiálják, szintén csökkent H3K27ac-ót mutattak ezekben az egerekben. Ezek a változások főként olyan géneket érintettek, amelyek a neuronális aktivitást, neuronális plaszticitást és transzmissziót szabályozzák. ${ }^{240}$

A hisztonok metilációs szintjét szabályozó enzimek szintén deregulációt mutatnak HD modellekben. Ilyen az ESET/SETB1 H3K9 metiltranszferáz, melynek szintje megnövekedett az R6/2 HD-s egerek striátumában és kortexében az SP1/SP3-mediálta transzkripciós aktivációnak köszönhetően, melynek hatására megnövekedett a hisztonok H3K9 metilációja. ${ }^{264}$ A H3K4me3 szintjében csökkenést fedeztek fel R6/2 egerekben a demetilálásában részt vevő KDM5C/JARID1C enzim upreguláltságának következtében, neuronális gén downregulációt okozva a HD-s egerek striátumában és kortexében. ${ }^{239} 240265$ Különböző 
hosszúságú CAG ismétlődést hordozó mHtt-t expresszáló embrionális őssejteken (ESC) és neuronális progenitor sejteken (NPC) végzett kísérletek során korrelációt fedeztek fel a CAGismétlödés-függő génexpressziós változások és a $\mathrm{H} 3 \mathrm{~K} 4 \mathrm{me} 3$ szintje között. Ez a neuronális őssejtek (NSC) esetén kifejezettebb volt, ami azt sugallja, hogy a mHtt befolyásolja az epigenetikai szabályozást a korai neuronális differenciációs állapotok során. A Htt null mutáció esetében ESC sejtekkel végzett kísérletekben egy általános H3K27me3 csökkenést is kimutattak, míg NPC sejtekkel végzett kísérletek során az ellenkezője történt ennek, azt sugallva, hogy a Htt részt vehet a H3K27me3 eltüntetésében sejt differenciácós állapot függő módon. ${ }^{266} \mathrm{HD}$-s páciensek prefrontális kortexén végzett kísérletek során is kimutattak H3K4me3 szint növekedést olyan gének promóterein, amelyek neuronális aktivitás és gyulladásos folyamatok szignalizációs útvonalaiban vesznek részt. ${ }^{267}$ A H3K9me2 heterokromatitinizációval összefüggő kromatin jel megemelkedett szintjét is kimutatták mind HD-s páciensek, mind R6/2 egerek striátumában. ${ }^{264}$

Emelkedett H2A ubikvitinációs szintet is megfigyeltek R6/2 egerekben. ${ }^{268}$ A striatális H2A ubikvitinációs változások arra utalnak, hogy a hiszton változások nem csak a diszregulált géneket érintik. ${ }^{269}$

Teljes genom metilációs analízist is végeztek HD sejt modelleken. Az eredmények szerint a mHtt fehérjék hatására DNS metilációs változások jelentek meg mind a proximális, mind a disztális promóter szabályozási régiókon. ${ }^{265} \mathrm{HD}$-s páciensekből származó poszt-mortem agykéreg és máj mintán végzett DNS metilációs analízis eredményeként azt találták, hogy a $H t t$ promótere szövetspecifikus metilációt mutatott, ami szövetspecifikus promóter aktivitáshoz vezetett. ${ }^{270} \mathrm{Az}$ 5-hidroximetilcitozin (5-hmC) és a 7-metilguanin (7-mG) szintje HD-s egerekben globálisan lecsökkent az agyban. ${ }^{271} 272$

\section{I.8. Drosophila, mint Huntington-kór modell}

A Drosophila melanogaster, más néven ecetmuslica, az egyik legelterjedtebben használt kísérleti organizmus, mivel egyszerü és kiválóan jellemzett genommal rendelkezik, genetikai módosításához fejlett eszköztár áll a kutatók rendelkezésére, és emellett kiváló modell számos humán betegség tanulmányozására. A D. melanogaster 4 pár kromoszómával rendelkezik, melyek közül az első a nem meghatározásban vesz részt, a többi 3 pedig autoszómális, a 4 . nagyon kis méretü. ${ }^{273}$ A D. melanogaster genom projekt 2000-ben került befejezésre. Genommérete megközelítőleg $180 \mathrm{Mb}$, melynek a 2/3-a eukromatikus, 1/3 pedig heterokromatikus régió. Genomja megközelítőleg 18.000 gént foglal magába. ${ }^{274} 275$ Bár a fehérjék teljes aminosav szekvencia hasonlósága a Drosophila és az emlösök között megközelítőleg $40 \%$, a fehérjék konzervált funkcionális doménjei több, mint $80 \%$-os egyezést mutatnak. ${ }^{276}$ A Drosophila genom projekt eredményeit összevetve a humán genommal kiderült, hogy az emberi betegség gének közel 75\%-ának van funkcionális orthológja muslicában. 277

A Drosophilát már több, mint 100 éve alkalmazzák genetikai analízisek során. Elsőként William E. Castle tanulmányozta az 1900-as évek elején ${ }^{278}$, majd 1909-ben Thomas Hunt Morgan kezdte el genetikai kísérletekre használni. Az ezt követő 30 évben klasszikus 
genetikai kísérletekkel sikerült a gének, kromoszómák és az öröklődő genetikai információ fő törvényszerüségeit megállapítani. Eleinte a mutagenezis technikák a besugárzásos és vegyszeres kezeléseken alapultak, majd az 1970-es évektől számos molekuláris biológai eljárás indult fejlődésnek. Ilyenek a gén klónozás, a hibridizációs technikák, vagy a P-elemen alapuló transzformációs módszer. ${ }^{276}$

A Drosophila kísérletes szempontból előnyös tulajdonságai közé tartozik, hogy rövid idő alatt több utódgenerációban nagyszámú utódot (generációs ideje $25^{\circ} \mathrm{C}$-on 10 nap, akár több száz utód szülőpáronként) képes létrehozni. A különböző stádiumú egyedeken (embrió, lárva, báb, adult) a vizsgálat céljának megfelelően eltérő jellegü kísérletes módszerek kivitelezhetőek. Az adult állatok szervei funkcionálisan hasonlóak az emlős szervekhez (agy, bél, keringési-, kiválasztó- és reproduktív rendszer). A muslica agy több mint 100.000 neuront tartalmazó egyedi hálózat, amely komplex viselkedési mintázatok kialakítására és feldolgozására képes (cirkadián ritmus, tanulás és memória kialakítás, udvarlás és agresszió). Mindemellett apró méretü, könnyen fenntartható és manipulálható laboratóriumi körülmények között. Számos mutáns és transzgenikus törzs beszerezhető törzsközpontokból, mint amilyen a Bloomington Drosophila Stock Center, a Kyoto Stock Center vagy a Vienna Drosophila Resource Center. Ezen kívül bárki számára elérhető online adatbázisok és kísérleti eszközök széles köre áll rendelkezésre. ${ }^{276}$

A kísérletes munkához rendelkezésre állnak olyan speciális kromoszómák, amelyek lehetővé teszik a vizsgált jellegzetesség nyomonkövetését anélkül, hogy az átkereszteződhetne és „elveszhetne” a következő generációkban. Ezeket balanszer kromoszómáknak nevezzük, melyek a kívánt funkció betöltéséhez inverziókat tartalmaznak a kromoszóma teljes hosszán, valamilyen fenotípusban megnyilvánuló, egyszerüen nyomon követhető úgynevezett „,marker gén”-t, továbbá egy recesszív letális mutációt is. ${ }^{279}$

Egy általánosan elterjedt módszer Drosophilában a gének expressziós szintjének megemelésére vagy csökkentésére, azok funkciójának vizsgálatához, a GAL4-UAS expressziós rendszer. ${ }^{280}$ A GAL4 (galactose-responsive transcription factor GAL4) egy élesztő transzkripciós faktor, amely az UAS (upstream-activating sequence) szekvenciához kötődve elindítja annak a génnek az expresszióját, amely promótere előtt található. Ha a GAL4 megtalálható az egyik muslica törzsben, míg az UAS szekvencia a vizsgálni kívánt transzgén elött egy másik törzsben, akkor ezeket keresztezve olyan utódokat hozhatunk létre, amelyekben a transzgén expressziója a GAL4 driver által meghatározott fejlődés- és szövetspecifikus módon valósul meg. A génexpresszió csökkentése, vagy „csendesítése” pedig RNS interferenciával valósítható meg. ${ }^{276}$ Tehát a Perrimon és kollégái által kifejlesztett GAL4-UAS rendszer használata térben és időben kontrollálható expressziót biztosít a kifejeztetni vagy csendesíteni kívánt gén számára. ${ }^{281}$

A Drosophila széles körben alkalmazott modell a neurodegeneratív betegségek tanulmányozására is. Ezek közé tartozik a Huntington-kór, mely esetén a betegség modellben neuronálisan expresszáltatható a teljes hosszúságú humán Huntingtin gén meghosszabbodott poliglutamin domént kódoló szakasszal, vagy a humán $H t t$ gén $\mathrm{N}$-terminális fragmentjei meghosszabbodott poliglutamin kódoló szakasszal. A meghosszabbodott poliglutamin domént hordozó Huntingtin fragmentumok overexpressziója hatékonyan indukálja a jellemző 
fenotípusokat muslicákban. Ezek az állatok olyan neuronális diszfunkciókat mutatnak, mint amilyen a szinaptikus transzmisszió és axonális transzport hibái, a neuronális degeneráció, a mozgás problémák és a rövidebb élettartam. 252282283284285

A Drosophila egy hatékony modell, amelynek egyszerübb a kezelése az emlős modell rendszereknél és jóval magasabb komlexitásúak az élesztő sejteknél. Alkalmas gén funkció és fehérje kölcsönhatások vizsgálatára, molekuláris mechanizmusok, celluláris folyamatok felderítésére, humán betegségekben új biomarkerek és terápiás targetek keresésére, azonban az elsődleges felfedezések utáni részletesebb mechanizmusok vizsgálatára az emlös modellek alkalmasabbak. ${ }^{276}$ 


\section{Célkitüzések}

Tekintve, hogy a Huntington-kór jelenleg gyógyíthatatlan és csak tüneti kezelésére van lehetöség, célunk volt különböző genetikai és molekuláris biológiai vizsgálatokkal a kór pathogenezisét befolyásoló epigenetikai targetek keresése és jellemzése. Ismert az, hogy a hisztonok acetilációs állapota befolyásolja a betegség lefolyását, e folyamatban érintett konkrét acetilációs pozíciók azonban csak részlegesen azonosítottak, kevéssé jellemzettek. Ezért a következő kísérleti lépéseket és az alábbi kérdések megválaszolását tüztük ki célul:

\section{II.1. A Drosophila Hat1 általános jellemzése és hatásának vizsgálata a Huntington-kór patogenezisében}

1. Hat1 deléciós mutáns Drosophila melanogaster törzset állítunk elö:

Erre a génre korábban nem állítottak elő null mutáns vonalat, ezért P-elem transzpozon remobilizációval tervezünk deléciós mutánst létrehozni funkcionális vizsgálatainkhoz.

2. Meghatározzuk a Hatl enzim hiszton acetilációs targetjeit.

A létrehozott Drosophila melanogaster Hatl deléciós mutáns vonalat használva western blot kísérletekben vizsgáljuk a H4 hiszton acetiláltságát.

3. Megállapítjuk, szükségesek-e a Hat1 által létrehozott hiszton poszt-transzlációs módositások a H4 hiszton nukleáris transzportjához.

Létrehozunk olyan kanonikus H4 hisztonéval megegyező aminosav szekvenciájú FLAGtag-gel jelölt His4r trangént expresszáló törzseket, melyekben lehetetlenné tesszük a H4K5 és K12 acetilációt. Ezekben az egyedekben lárvális nyálmirigy immunfestéssel megvizsgáljuk a variáns hisztonok sejten belüli lokalizációját.

4. Megállapítjuk a Hat1 hiszton acetiltranszferáz génexpresszióra gyakorolt hatását.

A létrehozott deléciós mutánson teszteljük, hogy van-e az enzimnek hatása a kromatin szerveződésre és génexpresszióra. Ehhez pozíció effektus variegációs tesztet és transzkriptomikai analízist végzünk.

5. Meghatározzuk a Hatl hiányának hatását az egyedek egyes fenotípusaira.

Jellemezzük a Hat1 deléciós mutáns vonalnak az életképességre, élettartamra és fertilitásra gyakorolt hatását.

6. Megvizsgáljuk a Hat1 teljes vagy részleges hiányának hatását egyes stressz körülmények között. 
Megvizsgáljuk a Hat1 hiányának a hőstressz és proteopáthiás stressz válaszra gyakorolt hatását. Ez utóbbi során a Huntington-kór Drosophila modelljében kívánjuk tesztelni a Hat1 csökkent szintjének a hatását életképesség, élettartam és a retinális neurodegeneráció vizsgálatával.

\section{II.2. His4r variáns hiszton fehérjék acetilációs módosításainak hatása a Huntington-kór patomechanizmusára}

1. Különbözö pozíciókban acetilációt mimikáló His4r variáns hisztont hordozó vektorkonstrukciókat hozunk létre.

Site Directed Mutagenezissel olyan konstrukciókat hozunk létre, amelyekben a His4r gén 5-ös, 8-as, 12-es vagy 16-os pozíciójú lizinjét glutaminra (acetilációt mimikál) vagy arginira (acetilálatlan/módosítatlan állapotot mimikál) cseréljük. Továbbá létrehozunk kontrollként egy módosítatlan His4r gént hordozó konstrukciót is. A transzgéneket a követhetőség érdekében egy C-terminális FLAG-tag jelöléssel látjuk el.

2. Különbözö pozíciókban acetilációt mimikáló His4r variáns hiszton fehérjét expresszáló transzgenikus Drosophila törzseket hozunk létre és azokat többrétüen validáljuk.

A módosított His4r génszekvenciákat pTWF-attB vektorba klónozva Drosophila embriókba injektáltatjuk, melyekből transzgenikus vonalakat állítunk elö. Ellenőrizzük a szubsztitúciók jelenlétét a transzgének visszaizolálásával és szekvenáltatásával. A transzgének RNS és fehérje expresszióját ellenőrizzük qPCR-al és western blot-tal. A transzgének sejten belüli lokalizációját lárvális nyálmirigy immunfestéssel határozzuk meg.

3. Megállapítjuk, hogy a His4r variáns hiszton fehérje különbözö acetilációs állapotait mimikáló transzgének expressziója hatással van-e az életképességre és a neuronális pusztulásra.

Megvizsgáljuk a transzgének elav-GAL4 driver indukálta neuronális expressziójának hatását az egyedek fenotípusára. Ezt az állatok kikelésének és retinális neurodegenerációjának tesztelésével tervezzük vizsgálni.

4. Megvizsgáljuk, hogy a His4r variáns hiszton fehérje különbözö acetilációs állapotait mimikáló transzgének expressziója milyen hatással van a Huntington-kór Drosophila modelljében.

Vizsgálni kívánjuk a mutáns Huntingtint expresszáló muslicák életképességét, élettartamát, retinális neuron pusztulásuk mértékét és motoros képességeiket. 


\section{Anyagok és módszerek}

\section{III.1. Drosophila fenntartás, keresztezések és fenotípus vizsgálatok}

\section{III.1.1. Felhasznált törzsek}

A kísérleteink során használt törzsek közül a bloomingtoni törzsközpontból (Bloomington Drosophila Stock Center, Bloomington, IN, USA) származnak a következőek: $y^{1} w^{67 c 23} ;$ P $\{$ EPgy2 $\} H a t 1^{\text {EY21697 }}, \quad w ;$ Dr 42-3/TM3 42-3, $\quad w^{1118}, \quad w^{m 4 h}, \quad w ; d a-G A L 4$, w P\{GawB\}elavC155, w; TM6 Sb/TM3 Ubx. A w; UAS-Httexlp-Q120 transzgenikus törzs J. Lawrence Marsh (University of California, Irvine, CA, USA), a ywM\{eGFP.vasint.Dm\}ZH-2A; +; M\{RFP.attP\}ZH-86Fb; + (röviden: $\Phi X 86 F b$ ) transzgén dokkoló helyet tartalmazó törzs Konrad Basler (University of Zurich, Svájc) laboratóriumából származik.

A törzsek fenntartásához és a keresztezésekhez standard Drosophila táptalajt használtunk (3\% száraz élesztő, 4\% kukoricadara, 2\% búzaliszt, $9 \%$ glükóz, $0,7 \%$ agar és $0,15 \%$ Tegosept). A petéztetéshez használt kísérletek során málnaszörppel kiegészített agar táplemezeket használtunk (5 $\mathrm{g}$ agar $150 \mathrm{ml} \quad \mathrm{H}_{2} \mathrm{O}$-ban feloldva, kiegészítve $50 \mathrm{ml}$ málnaszörppel és aktív szénnel).

\section{III.I.2. Hat1 deléció létrehozása transzpozon remobilizálással}

A deléció létrehozásához a P-elemet hordozó $y^{1} w^{67 c 23} ; P\{E P g y 2\} H a t 1^{E Y 21697}$ hímeket kereszteztük $\quad w$; $\operatorname{Dr} \triangle 2-3 / T M 3 \triangle 2-3$ nöstényekkel, melyek utódai közül a w; P\{EPgy2\}Hat1 ${ }^{E Y 21697} / T M 3 S b \triangle 2-3$ genotípusú, úgynevezett jump-starter hímeket w; +; TM6 Sb/TM3 Ubx genotípusú nőstényekhez kereszteztük. Az utódok közül a transzpozonon található mini-white markergént elveszítő, fehér szemü w; Hat1 ${ }^{\text {rev }}$ TM6 Sb revertáns hím egyedeket $w ;+$; TM6 Sb/TM3 Ubx nőstényekhez kereszteztük vissza egyedenként. A jelölt egyedeket PCR reakcióval teszteltük tovább (részletesen kifejtve a molekuláris módszereknél). A PCR eredmények alapján a $w$; Hat $1^{457}$ deléciós és $w$; Hat $1^{\text {REVI6 }}$ precíz revertáns vonalat választottuk ki, melyek esetében a Hatl gén szekvenciáját kapilláris szekvenálással (Delta Bio $2000 \mathrm{Kft}$ ) is ellenőriztük.

\section{III.1.3 Hat1 mutánsok életképességének, élettartamának és fekunditásának vizsgálata}

Az életképesség vizsgálathoz a Hat1 ${ }^{457}$ deléciós és Hat ${ }^{\text {REVl6 }}$ precíz revertáns egyedeket $\Phi X 86 F b$ törzshöz kereszteztük, a heterozigóta hím utódokat visszakereszteztük a homozigóta Hatl deléciós vagy revertáns nőstényekhez. Mindkét genotípus esetén minimum $10 \mathrm{db}$ keresztezésből kikelő homo- illetve heterozigóta utódok genotípusonkénti számát jegyeztük fel szemszínük alapján 5 napon keresztül. Az utódok összes egyedszáma mindkét keresztezés típus esetén meghaladta az 1400-at. 
Az élethossz vizsgálatokhoz a Hat ${ }^{457}$ és a Hat ${ }^{\text {REV16 }}$ homozigóta egyedeket használtunk. $20 \mathrm{db}$ állatot helyeztünk egy-egy fiolába és $25^{\circ} \mathrm{C}$-on tartva heti 2-3 alkalommal friss fiolákba ráztuk őket. Az elpusztult egyedek számát naponta feljegyeztük. Mindkét genotípus esetén a nőstényeket és a hímeket is vizsgáltuk. Mind a Hat1 ${ }^{457}$, mind a Hat1 ${ }^{\text {REV16 }}$ törzs esetén, nőstényekből és hímekből egyaránt 200-200 egyedet vizsgáltunk.

Nőstények fekunditásának vizsgálatához da-GAL4 > Hat1 ${ }^{E Y 21697}$ túltermelő nőstényeket, valamint a Hatl ${ }^{\text {REVl6 }}$ precíz revertáns és Hat $^{457}$ deléciós mutáns szűz nőstényeket kereszteztünk $w^{1118}$ genotípusú (fehér szemü, Hatl-re nézve vad típusú) hímekhez. 3 napos egyedeket kereszteztünk oly módon, hogy 5 nőstény és 3 hím került egy fiolába, melyeket 5 napig naponta átráztunk és a 24 óra során lerakott petéket számoltuk. Minden genotípusú keresztezésből 10 párhuzamos került indításra, vagyis $50 \mathrm{db}$ nőstény fekunditását vizsgáltuk genotípusonként.

\section{III.1.4. Szem pigment koncentrációjának meghatározása spektrofotometriával}

3-4 napon keresztül gyüjtött és $25{ }^{\circ} \mathrm{C}$-on tartott $w^{m 4 h}$ genotípusú szüz nőstényeket kereszteztünk frissen kelt Hat ${ }^{\text {REVI6 }}$ precíz revertáns, illetve Hat ${ }^{457}$ deléciós mutáns hímekkel. Az utódokat 5 napon keresztül ugyanabban az időpontban gyüjöttük, majd 1 hét elteltével folyékony nitrogénben fagyasztottuk. Az állatokat $-80{ }^{\circ} \mathrm{C}$-on tároltuk a kellő mennyiség összegyüjtéséig és egyszerre készítettünk belőlük mintát a fotometriás méréshez. $20 \mathrm{db}$ muslica fejet homogenizáltunk $600 \mu \mathrm{l}$ 0,1\%-os ammóniaoldat és $600 \mu \mathrm{l}$ kloroform elegyében. Ezt az elegyet centrifugáltuk 4 percig 13.000 rpm-en majd a felülúszót fotometráltuk $485 \mathrm{~nm}$-es hullámhosszon. Ezt követően a mért abszorbancia értékeket hasonlítottuk össze. Minden genotípusból 10 párhuzamos mintát készítettünk, vagyis az egyes genotípusokból $200 \mathrm{db}$ egyedet vizsgáltunk.

\section{III.1.5. Cirkadián ritmus és napi aktivitás vizsgálata}

A Hatl ${ }^{\text {REVI6 }}$ precíz revertáns és Hatl $^{457}$ deléciós mutáns egyedeket a vizsgálatot megelőzően és annak során is $25^{\circ} \mathrm{C}$-on 12 órás fény/sötét megvilágításban tartottuk. 7 napos hím egyedeket használtunk a vizsgálat során és genotípusonként 38 egyeden végeztük el a mérést. Az egyedeket egyesével $5 \mathrm{~mm}$ átméröjü üveg fiolákba helyeztük, majd a fiolákat DAM2 Drosophila Activity Monitor (TriKinetincs Inc) mérőeszközbe helyeztük, amelyben mozgási aktivitásukat 5 napon keresztül nyomon követtük. Ha egy állat a mérömüszerben megszakítja az infravörös sugárnyalábot, azt a DAM2 berendezés érzékeli az adatokat gyüjtő DAMSystem3 szoftver pedig egy szöveg fájlba írja. Az adatok elemzését DAMFileScan (TriKinetics Inc) és pySolo programmal végeztük ${ }^{286}$.

\section{III.1.6. Höstressz érzékenység vizsgálata}

A kísérlet során frissen kikelt Hat $^{\Delta 57}$ deléciós mutáns és Hat1 ${ }^{\text {REVl6 }}$ precíz revertáns egyedeket 7 napon keresztül $25^{\circ} \mathrm{C}$-on tartottunk, majd hőstressznek tettük ki őket és a 
hősokkot követő 18 -20 órás $25{ }^{\circ} \mathrm{C}$-on történő inkubáció (recovery) elteltével feljegyeztük az életben maradt egyedek számát. A $37{ }^{\circ} \mathrm{C}$-os hőstressz vizsgálatot légtermosztátban, a $40{ }^{\circ} \mathrm{C}$ os kísérletet vizes inkubátorban végeztük. A $37^{\circ} \mathrm{C}$-os kísérletnél a fiolák 0,5-1 cm vastagságú táptalajt és 25 egyedet tartalmaztak, a $40{ }^{\circ} \mathrm{C}$-os tesztelésnél üres fiolákba 10-15 állatot helyeztünk. A $37{ }^{\circ} \mathrm{C}$-os hősokk vizsgálatot 7 órán keresztül végeztük, ahol a vizsgálati időpontok az első 3 órában óránként, az azt követő 4 órában pedig fél óránként voltak, és genotípusonként 100 egyedet teszteltünk időtartamonként. A $40{ }^{\circ} \mathrm{C}$-on végzett kísérlet 25,30 és 35 perces időtartamokig zajlott, genotípusonként minimum 120 egyeddel időtartamonként. A fiolákat egyszerre heyeztük a légtermosztátba vagy vizes inkubátorba, és a vizsgálati időpontoknál a kellő egyedszámot tartalmazó mennyiségü fiolát vettük ki.

\section{III.I.7. His4r transzgenikus állatok törzsbe állítása}

A kodon szubsztitúciókat tartalmazó His4r transzgéneket hordozó vektor konstrukciókat attP-zh86Fb $\varphi$ C31 specifikus dokkoló helyet hordozó izogenizált embriókba injektáltattuk (MTA Szegedi Biológiai Kutatóközpont, Genetikai Intézet). A kikelt adult állatokat egyedenként $w^{1118}$ állatokhoz kereszteztük. A kikelő transzformáns utódokat a transzgénen található mini-white markergénre szelektáltuk. A transzformáns egyedeket w; +; TM6 Sb/TM2 Ubx állatokkal kereszteztük, majd az utódokat a hordozott balanszer szerint szétválogattuk és homozigóta törzseket hoztunk létre.

\section{III.1.8. Idegsejtekben expresszált His4r konstrukciók életképességre gyakorolt hatásának vizsgálata}

A His4r transzgének életképességre gyakorolt hatásának teszteléséhez heterozigóta transzgenikus pontmutáns His4r hímeket (w; +; His4r/TM6 Sb) elav-GAL4 drivert hordozó szűz nőstényekhez kereszteztünk, a kikelő utódok genotípusonkénti számát 5 napon keresztül feljegyeztük. A kikelt transzgént expresszáló utódok számát a nem expresszáló, elav-GAL4 drivert és balanszer kromoszómát hordozó testvéreik számához hasonlítottuk. Az életképesség adatok minimum 3 db keresztezést tartalmazó fiolából származó eredmények módosításonként (minden szubsztitúció esetén), a kikelt összes egyedszám pedig minimum $200 \mathrm{db} H i s 4 r$ transzgénenként.

\section{III.1.9. Életképesség és élettartam vizsgálatok mHtt-t expresszáló egyedekben}

A Hatl kísérletek során a $\operatorname{Hatl}^{\Delta 57}$ deléciós és a Hat $^{\text {REVl6 }}$ precíz revertáns hímeket elav-GAL4/w; +; Sb/TM6 Ubx szüz nőstényekhez kereszteztük. A His4r pontmutánsokkal végzett kísérletek során a His4r transzgenikus törzsekből származó hímeket kereszteztünk elav-GAL4/w; +; Sb/TM6 Ubx genotípusú szüz nőstényekhez. A Sb markert hordozó hím utódokat ezt követően $w$; UAS-Httexlp-Q120 szüz nőstényekhez kereszteztük. Az utódkategóriák közül a hímek nem expresszáló (elav-GAL4 neuronális driver nélküli, „egészséges”) kontrollok, a nőstények fele expresszálja a mutáns Huntingtin fehérjét, de nem 
hordozza a vizsgált genetikai elemeket (,beteg” kontroll egyedek), míg a másik fele expresszálja a mutáns Huntingtin fehérjét és hordozza vagy a $\operatorname{Hatl}^{457}$, vagy a $\operatorname{Hat1}^{\text {REV16 }}$ allélt, vagy a megfelelö His $4 r$ transzgént.

Az egyedek életképességének teszteléséhez a kikelő utódok genotípusonkénti számát 5 napon keresztül jegyeztük fel. A Hatl kísérletek során összesen minimum 38 db keresztezést tartalmazó fiola volt vizsgálva allélenként $\left(\mathrm{Hatl}^{457}\right.$ és Hat ${ }^{\mathrm{REV} 16}$ ), ahol a 4 utódkategória összes egyedszáma minimum $1300 \mathrm{db}$ volt. A His4r transzgenikus törzsekkel végzett kísérletek esetén az életképesség adatok minimum 12 db keresztezést tartalmazó fiolából származó eredmények módosításonként (minden szubsztitúció esetén), a kikelt összes egyedszám pedig minimum $430 \mathrm{db}$ transzgénenként.

Az élethossz vizsgálatokhoz 10-35 állatot helyeztünk egy-egy fiolába és $25{ }^{\circ} \mathrm{C}$-on tartva heti 2-3 alkalommal friss fiolákba ráztuk őket. Az elpusztult egyedek számát naponta feljegyeztük. A Hat1 ${ }^{457}$ esetén az élethossz vizsgálathoz használt összes egyedszám meghaladta az 1000 egyedet (mHtt expresszáló kategóriák esetén minimum 110 egyed), a Hat1 ${ }^{\text {REV16 }}$ allél esetén pedig meghaladta a 400 egyedet (mHtt expresszáló kategóriák esetén minimum 30). A His4r élettartam vizsgálatok során az életképes kategóriák esetén az összes egyedszám minimum 490 egyed volt szubsztitúciónként (mHtt expresszáló kategóriák esetén minimum $20 \mathrm{db}$, kivétel K5R - 2db, K8R - $10 \mathrm{db}$ ).

\section{III.1.10. Neurodegeneráció vizsgálata pseudopupil assay-el}

A neurodegeneráció mértékének vizsgálatára úgynevezett pseudopupil módszert alkalmaztunk. Frissen dekapitált állatok fejét átlátszó körömlakk segítségével tárgylemezre rögzítettük, majd immerziós olajjal lefedtük, és az összetett szemeket Nikon Eclipse 80i mikroszkóppal 50X nagyítású immerziós lencsével vizsgáltuk. Az összetett szemet felépítő ommatídiumokban megfigyelhető rhambdomerek ommatídiumonkénti számát jegyeztük fel a vizsgálat során. A kísérletet genotípusonként minimum 10 egyeden hajtottuk végre és egyedenként minimum 20 ommatídiumot vizsgáltunk (kivétel: az elav-GAL4/w; HttQ120/+; His4r/+ genotípusú egyedek esetén a 2 napos vizsgálat során 4 db K8R, a 4 napos vizsgálat során 7 db K8R muslicát teszteltünk).

\section{III.2. Molekuláris biológiai módszerek}

\section{III.2.1. Hat1 mutációk azonosítása PCR-ral}

Azokhoz a PCR reakciókhoz, amelyeket a Hatl deléciók gélelektroforézissel történő tesztelése céljából készítettünk, egyedi muslicákból preparáltunk DNS-t Greg Gloor és William Engels (Dept. of Genetics, Univ. of Wisconsin, Madison, USA) protokollja alapján a következő módon: egy egyedet homogenizáltunk $50 \mu$ úgynevezett „Squashing Buffer”-ben (10 mM Tris-HCl pH 8,2, $1 \mathrm{mM}$ EDTA, $25 \mathrm{mM} \mathrm{NaCl}, 200 \mu \mathrm{g} / \mathrm{ml}$ Proteináz K) és $37^{\circ} \mathrm{C}$-on hőkezeltük egy órán keresztül, majd $85{ }^{\circ} \mathrm{C}$-on inkubáltuk további 15 percig a proteináz 
inaktiválásához. A kapilláris szekvenáláshoz készített PCR reakciókhoz a genomi DNS kivonását E. Jay Rehm (Berkeley Drosophila Genome Project) protokollja (Quick Fly Genomic DNA Prep.) szerint végeztük a következőképpen: 15 egyedet homogenizálunk 200 $\mu 1$,Buffer A”-ben (100 mM Tris-HCl pH 7,5, 100 mM EDTA, 100 mM NaCl, 0,5\% SDS) és hőkezeltük $65{ }^{\circ} \mathrm{C}$-on 30 percig. Ezt követően $400 \mu \mathrm{l}$, ,LiCl/KAc Solution”-t (5 M KAc : $6 \mathrm{M}$ LiCl 1:2,5 rész arányban) adtunk hozzá és jégen inkubáltuk 10 percig. Centrifugáltuk 15 percig és $500 \mu$ felülúszóhoz $600 \mu$ lizopropanolt mértünk, majd újra centrifugáltuk az elegyet 15 percig. A felülúszó eltávolítása után a csapadékot mostuk 70\%-os etanollal, majd száradás után $75 \mu \mathrm{TE}$ pufferben oldottuk vissza. A PCR reakciókat olyan primerekkel végeztük, amelyek alkalmasak azon deléciók detektálására, amelyek nem érintik a szomszédos géneket. A primerek szekvenciái a következőek voltak: Hat1.F: ACCAGAGCGAGATGTGTCAC, Hat1.R: AGAACCTACGAGGCCCTCAA. A PCR-t genomi DNS templáton Dream Taq DNS polimeráz (Thermo Fisher Scientific, TFS) felhasználásával a gyártó utasításai szerint végeztük. A PCR program a következő lépésekből állt: $1.95{ }^{\circ} \mathrm{C} 3$ perc; $2.95{ }^{\circ} \mathrm{C} 30 \mathrm{mp} ; 3.60{ }^{\circ} \mathrm{C} 30 \mathrm{mp} ; 4.72{ }^{\circ} \mathrm{C} 2$ perc $30 \mathrm{mp} ; 5.72{ }^{\circ} \mathrm{C} 7$ perc; $6.4{ }^{\circ} \mathrm{C}$, a $2-4$ lépések 35 ciklusban voltak ismételve.

\section{III.2.2. Pontmutáns His4r transzgének és transzgenikus törzsek létrehozása}

A pontmutáns transzgének létrehozásához templátként egy His4r génszakaszt intronjaival együtt hordozó pENTR3C vektrokonstrukciót - pENTR3C-His4r-GB - használtunk. Ezt a konstrukciót előzőleg úgy hoztuk létre, hogy a His4r gént vad típusú $w^{1118}$ genotípusú egyedek genomi DNS-én elvégzett PCR reakcióval amplifikáltuk His4r.gF (GGTACCGCACACACACATGGATTAAG) és His4r.gR (GGTACCGGGAGAGCTAAATTTGCAG) primerekkel Q5 High-Fidelity DNS polimerázt (New England Biolabs, NEB) használva a gyártó protokollja szerint. Ezt követően a génszakaszt pJET1.2 vektorba klónoztuk CloneJET PCR cloning kit (TFS) alkalmazásával a gyártó javaslata szerint. A His4r gén start kodontól a stop kodon előtti kodonig terjedő szakaszát PCR reakcióval amplifikáltuk a pJET1.2-His4r vektorról His4r.E3C.F (GGTACCAAAATGACTGGTCGTGGAA) és His4r.E3C.R (GAATTCGCACCGCCAAATCCGTA) primerekkel Q5 DNS polimeráz használatával. A szekvenciát pJET1.2 vektorba inszertáltuk vissza CloneJET PCR cloning kit-tel. Ezt a konstrukciót FastDigest KpnI és EcoRI (TFS) restrikciós enzimekkel emésztettük, majd a $H i s 4 r$ fragmentet ugyan ezen enzimekkel felnyitott pENTR3C Gateway Entry vektorba ligáltuk, így előállítva a pENTR3C-His4r-GB konstrukciót.

A NEB Q5 irányított mutagenezishez a PCR reakciókat a gyártó javaslata szerint mértük össze, templátként a pENTR3C-His4r-GB konstrukciót használtuk. Az általunk használt PCR program:1. $98{ }^{\circ} \mathrm{C} 30 \mathrm{mp} ; 2.98{ }^{\circ} \mathrm{C} 10 \mathrm{mp} ; 3.58{ }^{\circ} \mathrm{C}-\mathrm{K} 5,60{ }^{\circ} \mathrm{C}-\mathrm{K} 8,63{ }^{\circ} \mathrm{C}-\mathrm{K} 12,65{ }^{\circ} \mathrm{C}-$ $\mathrm{K} 1630 \mathrm{mp} ; 4.72{ }^{\circ} \mathrm{C} 2$ perc; $5.72{ }^{\circ} \mathrm{C} 7$ perc; $6.4{ }^{\circ} \mathrm{C}$, a 2-4. lépés 25 ciklusban ismételve. Az alkalmazott szubsztitúciót hordozó primerek szekvenciái a következőek voltak (a kis betűvel jelölt szekvencia részletek az érintett kodon tripletek, az aláhúzott szakaszok pedig reakcióban módosított nukleotidok): 
$\underline{\text { K5R Forward primer: }}$

K5Q Forward primer:

K5 Reverse primer:

$\underline{\text { K8R Forward primer: }}$

K8Q Forward primer:

K8 Reverse primer:

$\underline{\mathrm{K} 12 \mathrm{R} \text { Forward primer: }}$

K12Q Forward primer:

$\underline{\text { K12 Reverse primer: }}$

$\underline{\text { K16R Forward primer: }}$

K16Q Forward primer:

$\underline{\text { K16 Reverse primer: }}$
TGGTCGTGGAgcGGAGGCAAAGG

TGGTCGTGGAaagGGAGGCAAAGG

GTCATTTTGGTACCGGATC

AAAGGGAGGCcgcGGATTGGGAAAG

AAAGGGAGGCcagGGATTGGGAAAG

CCACGACCAGTCATTTTG

AGGATTGGGAggGGGGGCGCCAAG

AGGATTGGGAaaaGGGGGCGCCAAG

TTGCCTCCCTTTCCACGA

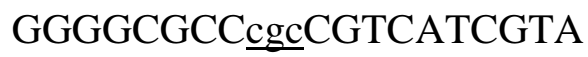

GGGGCGCCcagCGTCATCGTA

CCTTTCCCAATCCTTTGCC

A K5RK12R kettős szubsztitúció létrehozása úgy történt, hogy a His4r-K12R módosított pENTR plazmidon végeztünk később egy további inverz PCR reakciót a K5R primerpárral.

A PCR termékeket Agencourt AMPure XP gyöngyökkel (Beckman Coulter) tisztítottuk, majd Kináz-Ligáz-DpnI kezelésnek vetettük alá T4 polinukleotid kináz (TFS), T4 DNS ligáz (TFS) és DpnI (TFS) felhasználásával a gyártó javaslatai szerint. A Kináz-Ligáz-DpnI kezelt tisztított PCR mintákat E. coli DH5a kompetens sejtekbe transzformáltuk, majd a tisztított plazmidokat EcoRI-KpnI restrikciós endonukleáz kezeléssel teszteltük és Sanger szekvenálással (DeltaGene, Szeged) ellenőriztük. A megfelelő klónokat pENTR3C vektorból Gateway LR Clonase II Enzyme Mixel (TFS) pTWF-attB vektorba klónoztuk (módosított pTWF Gateway destination vektor, amely tartalmazza a $\varphi \mathrm{C} 31$ attB régiót az NsiI restrikciós helyre klónozva). A konstrukciókat DH5a sejtekbe transzformáltuk, majd a kolóniákból izolált plazmidokból EcoRI-KpnI restrikciós endonukleázzal végzett tesztelés alapján megfelelőnek bizonyultakból NucleoBond Xtra Midi kittel (Macherey-Nagel) embrió injektáláshoz megfelelő tisztaságú preparátumot készítettünk. A plazmidokat attP-zh86Fb III. kromoszómás inszerció dokkoló helyet hordozó embriókba injektáltattuk (MTA Szegedi Biológiai Kutatóközpont, Genetikai Intézet).

\section{III.2.3. Az integrált pontmutáns His4r transzgének szekvencia ellenörzése}

A transzgenikus törzsekből genomi DNS-t izoláltunk E. Jay Rehm (Berkeley Drosophila Genome Project) protokollja (Quick Fly Genomic DNA Prep.) szerint, majd a mintákon PCR reakciót végeztünk Dream Taq polimerázzal (TFS) a gyártó javaslata szerint a következő primerekkel: pTWF-SeqF (GCAACTACTGAAATCTGCCAAGAAG), pTWF-SeqR (AAGGTTCCTTCACAAAGATCCTCT). Az általunk használt PCR program: $1.95{ }^{\circ} \mathrm{C} 3$ perc; $2.95{ }^{\circ} \mathrm{C} 30 \mathrm{mp} ; 3.66{ }^{\circ} \mathrm{C} 30 \mathrm{mp} ; 4.72{ }^{\circ} \mathrm{C} 75 \mathrm{mp} ; 5.72{ }^{\circ} \mathrm{C} 5$ perc, $6.4{ }^{\circ} \mathrm{C}$, a 2-4. lépés 
35 ciklusban ismételve. A PCR mintákat ellenőrző agaróz gélelektroforézist követően Sanger szekvenálással (DeltaGene, Szeged) ellenőriztük. Mindegyik szekvencia hordozta az általunk készített szubsztitúciókat.

\title{
III.2.4. mRNS szint vizsgálata RT-qPCR-ral
}

RNS expressziós szint vizsgálatot végeztünk 3 napos elav-GAL4 neuronális driverrel indukált His $4 r$ transzgént hordozó egyedeken, valamint Hatl expressziós vizsgálatot végeztünk 1 napos, 3 napos, 1 hetes, 2 hetes és 6 hetes $w^{1118}$ vad típusú egyedeken. Az RNS izoláláshoz mintánként $20 \mathrm{db}$ adult muslica fejet homogenizáltunk $100 \mu 1$ Trizol reagensben (Invitrogen), az RNS-t a gyártó protokollja szerint tisztítottuk, majd $20 \mu$ DEPC kezelt vízben oldottuk fel. Ezt követöen 500 ng RNS mintát DNaseI enzimmel (TFS) kezeltünk a gyártói javaslat szerint. A $11 \mu \mathrm{l}$ végtérfogatú DNaseI kezelt RNS mintákból 9,6 $\mu$ l-t felhasználva TaqMan Reverse Transcription Reagents (TFS) és random hexamer primerek alkalmazásával a gyártói protokollt követve egyesszálú cDNS-t állítottunk elő. A cDNS mintákat kvantitatív real-time PCR (qPCR) reakciókban vizsgáltuk PikoReal RT-PCR berendezésben SensiFAST SYBR ${ }^{\circledR}$ No-ROX Kit (Bioline) alkalmazásával a gyártói protokoll szerint. A cDNS templátokból a mérés során $5 \mathrm{x}, 25 \mathrm{x}, 125 \mathrm{x}$ és $625 \mathrm{x}$ hígítású mintákat használtunk kalibrációként. Az alkalmazott PCR program a következő volt: 1. polimeráz aktiváció: $95{ }^{\circ} \mathrm{C}$ 7 perc; 2. denaturáció: $95{ }^{\circ} \mathrm{C} 15 \mathrm{mp} ; 3$. annealing - elongáció $60^{\circ} \mathrm{C} 60 \mathrm{mp}$; a 2-3 lépés 40 ciklusban ismétlődött. Az értékelés során tubulin génexpresszióra normalizáltuk a kapott értékeket.

Alkalmazott expressziós primerek:

\author{
Hat1 qF: GTGGTGTTACTTCTTGAGCTACG \\ Hat1 qR: GGTAGCCAAGCCGAGTTTCT \\ His4r qF: TCGCGGTGTGCTAAAGGTATTC \\ pTWF-attB-qR: AAGGTTTCCTTCACAAAGATCCTCT \\ tubulin qF: TGTCGCGTGTGAAACACTTC \\ tubulin qR: AGCAGGCGTTTCCAATCTG
}

\section{III.2.5. RNS szekvenálás}

RNS izolálás: Szinkronizált 6-12 órás $w^{1118}$ és $w^{1118}$; + Hat ${ }^{157}$ embriókból totál RNS mintát készítettünk Qiagen RNeasy Plus Mini kit-tel. A minták tisztaságát NanoDrop ND1000 spektrofotométerrel, koncentrációját Qubit RNA HS Assay Kit (TFS) alkalmazásával, integritását pedig kapilláris gélelektorforézis segítségével vizsgáltuk Agilent RNA 6000 nano kitet használva Bioanalyzer 2100 (Agilent) berendezéssel.

Szekvenáló könyvtár készítés és szekvenálás: A polyA szelektált RNS szekvenáló könyvtárat $1 \mu \mathrm{g}$ totál RNS-ből TruSeq RNA sample prep kit v2 (Illumina) kittel, a gyártó által biztosított „low sample protocol” alkalmazásával készítettük. A szekvenáló könyvtár 
validálását és átlagos fragmenthosszúságának ellenőrzését kapilláris gélelektroforézissel, Bioanalyzer 2100 berendezéssel és Agilent High Sensitivity DNA kit használatával végeztük. $\mathrm{Az}$ átlagos fragment hosszúságot és kvantitatív PCR-on alapuló koncentráció mérést (NEBNext Library Quant Kit for Illumina, NEB) használtuk fel a könyvtár koncentrációk kiszámításához. A denaturált könyvtárak 15 pM-os koncentrációra hígítása után a szekvenálást Illumina MiSeq szekvenátorral, MiSeq Reagent Kit V3-150 használatával, 2x75 bp paired-end szekvencia leolvasások meghatározásával végeztük.

A kapott eredmények értékelése: Az elsődleges adatelemzést MiSeq Control Software v2.6 / Real-Time Analysis software v1.18.54 alkalmazásával hajtottuk végre. A Fastq fájlok minőségi vágását Trimmomatic v0.33 szoftverrel paired-end módban végeztük, majd a szekvenciákat TopHat2 ${ }^{287}$ programmal a dmr6.13 Drosophila melanogaster referencia genomhoz illesztettük. Az illesztési fájlok indexelését, rendezését és deduplikálását SAMtools szoftverrel tettük meg, majd az génexpressziós analízist Cufflinks programmal ${ }^{287}$ végeztük a FlyBase dmr6.13.gtf transzkript annotációját felhasználva. A génontológiai dúsulás elemzést PANTHER Overrepresentation Test segítségével hajtottuk végre (teszt típus: Fisher egzakt teszt FDR korrekcióval), GO génontológiai adatbázis felhasználásával a teljes Drosophila génkészletet használtuk referencia listaként.

\section{III.2.6. Western blot analizis}

Fehérjeminták készítése embriókból a Hat1-el kapcsolatos kísérletek során: A legyüjtött embriókat szonikációs pufferben (50 mM Tris-HCl pH7,9, 2 mM EDTA, $50 \mathrm{mM} \mathrm{NaCl}, 0,5$ mM DTT, 1x PIC, 10 mM Na-butirát) homogenizáltuk, $1 \mathrm{mg}$ embrióhoz 7,88 $\mu$ l puffert használtunk. A mintákat szonikáltuk 4 cikluson át (30 mp szonikálás, $30 \mathrm{mp}$ szünet) magas fokozaton Diagenode Bioruptor szonikátorral. Ezt követően a mintákhoz azonos térfogatnyi 2x SDS-loading puffert adtunk és $95^{\circ} \mathrm{C}$-on 10 percig hőkezeltük őket.

Fehérjeminták készítése adult fejekből a His4r-el kapcsolatos kísérletek során: A gyüjtött állatokat lefagyasztottuk folyékony nitrogénben és vortexeltük. A fejeket összegyüjtöttük és homogenizáltuk szonikációs pufferben, 20 fejhez $25 \mu 1$ puffert használtunk. A mintákhoz azonos térfogatnyi 2x SDS-loading puffert adtunk és $95{ }^{\circ} \mathrm{C}$-on 5 percig hőkezeltük őket, majd centrifugáltuk 13.000 rpm-en 10 percig.

Tricin-SDS-PAGE: 10\%-os akrilamid gélt készítettünk, melynek összetétele a következö: szeparáló gél: $7 \mathrm{ml} \mathrm{3x}$ gél puffer, $7 \mathrm{ml} \mathrm{29:1} \mathrm{akrilamid:bis-akrilamid,} 7 \mathrm{ml} \mathrm{H}_{2} \mathrm{O}, 100 \mu 1$ 10\% APS, $50 \mu$ TEMED; stacking gél: $2 \mathrm{ml} 3 \mathrm{x}$ gél puffer, $1 \mathrm{ml}$ 29:1 akrilamid:bis-akrilamid, $3 \mathrm{ml}$ $\mathrm{H}_{2} \mathrm{O}, 40 \mu \mathrm{l} 10 \%$ APS, $20 \mu \mathrm{l}$ TEMED. Az általunk használt pufferek: $3 \mathrm{x}$ gél puffer $(3 \mathrm{M}$ Tris, $1 \mathrm{M} \mathrm{HCl}, 0,3 \%$ SDS, pH8,45 beállítása $0,33 \mathrm{M} \mathrm{HCl}$-el), 10x anód puffer ( $1 \mathrm{M}$ Tris, 0,225 M $\mathrm{HCl}), 10 \mathrm{x}$ katód puffer (1 M Tris, 1 M Tricin, 1\% SDS). Az elektroforézis során 15-30 $\mu \mathrm{g}$ fehérje mintát vittük fel átlagosan.

A blottolást nitrocellulóz membránra (GE Healthcare Life Scieneces) végeztük $40 \mathrm{~V}$-os feszültség alkalmazásával 2 órán keresztül $4{ }^{\circ} \mathrm{C}$-on. A blottoláshoz használt transzfer puffer összetétele a következő: $25 \mathrm{mM}$ Tris, $192 \mathrm{mM}$ glicin, 0,01\% SDS, $850 \mathrm{ml} \mathrm{H}{ }_{2} \mathrm{O}, 15 \%$ metanol. A blottolást követően a membránokat 5\%-os tejporban (tejpor 1x TBST-ben feloldva $-5 \mathrm{mM}$ 
Tris, $15 \mathrm{mM} \mathrm{NaCl}, 7,4 \mathrm{pH}, 0,05 \%$ Tween-20) blokkoltuk $4{ }^{\circ} \mathrm{C}$-on éjszakán át vagy szobahőn minimum 1 órán keresztül.

A membránokat 1\%-os tejport tartalmazó 1x TBST-ben hígított ellenanyagokkal inkubáltuk. Az elsődleges ellenanyagok a következőek voltak: anti-FLAG (M2 Cell Signaling Tech, 2368, 1:5000), anti-H3 (Abcam, ab1791, 1:4000), anti-H4K5ac (Abcam, ab61236, 1:500), anti-H4K8ac (Abcam, ab15823, 1:1000), anti-H4K12ac (Abcam, ab61238, 1:1000), anti-H3K18ac (Abcam, ab1191, 1:500), anti-H3K23ac (Abcam, ab47813, 1:1000). Ezeket 1-2 órán keresztül szobahőn vagy $4{ }^{\circ} \mathrm{C}$-on éjszakán át alkalmaztuk. Az elsődleges ellenanyaggal történő inkubáció után 1x TBST-ben mostuk a membránt 4-szer 10 percig, majd ráhelyeztük a másodlagos ellenanyagot. Ezek a következőek voltak: GAR-HRP (Dako) 1:4000-10000, RAM-HRP (Dako) 1:5000. A másodlagos ellenanyaggal 1-1,5 órát inkubáltuk a membránt szobahőn, majd ismét mostuk 4-szer 10 pericg 1x TBST-ben.

Az előhívást MILLIPORE Immobilon ${ }^{\mathrm{TM}}$ Western HRP szubsztrát használatával végeztük a gyártó utasítása szerint. A híváshoz C-DiGit Blot Scanner-t használtunk és a jelintenzitás értékeket a C-DiGit programmal határoztuk meg.

A jelintenzitás értékek összesítése során először a technikai replikátumoknak vettük az átlagát, majd az egyes biológiai replikátumokat átlagoltuk. A diagramokon ezek szórása látható feltüntetve. A H4K5ac vizsgálata során minimum 4 biológiai replikátumot vizsgáltunk genotípusonként, az estek többségében 2 technikai ismétléssel (1-3 technikai replikátum). A H4K12ac esetén genotípusonként 3 biológiai replikátumot vizsgáltunk átlagosan 2 technikai ismétléssel (1-3 technikai replikátum). A H4K8ac vizsgálatának eredményei 4 biológiai replikátum egy kísérleti értékeiből származnak. A H3K18 és H3K23ac mérése genotípusonként 3 biológiai replikátumon történt 4 technikai ismétléssel. Az egyes western blot kísérletek során használt embriók mennyisége 0,6-0,9 mg volt mintánként. A His4r fehérje expressziós vizsgálatok során 3 biológiai replikátumot vizsgáltunk genotípusonként 2 technikai ismétléssel. A western blot kísérletekben egyszerre felvitt minta mennyisége 4 adult muslica fejnek felel meg.

\section{III.2.7. Lárvális nyálmirigyek immunfestése}

Vándorló L3-as stádiumú lárvák nyálmirigyét boncoltuk ki fixáló oldatban (4\% formaldehid PBS-ben). A kiboncolt szöveteket áthelyeztük több lyukú plate-be és további 20 percig fixáltuk. A mintákat 3-szor 10 percig mostuk $400 \mu$ PBS-ben, majd 1 órán át permeabilizáltuk $400 \mu \mathrm{l} 0,5 \%$ Triton X-100-at tartalmazó PBS-ben. 45 percig blokkoltunk $400 \mu 1$ 5\% BSA-t tartalmazó PBST-ben (0,1\% TWEEN-20 PBS-ben), majd $300 \mu 1$ 1\% BSA-t tartalmazó PBST-ben 1:750 arányban hígított $\alpha$-FLAG M2 (F3165, Sigma) elsődleges ellenanyagot mértünk a mintákra és éjszakán át inkubáltuk őket $4{ }^{\circ} \mathrm{C}$-on himbán. Ezt követően 6-szor 10 percig mostuk a szöveteket $600 \mu$ PBST-ben, majd rámértünk $300 \mu \mathrm{l}$ 1\% BSA-t tartalmazó PBST-ben 1:1500 arányban hígított GAM-Alexa Fluor488 másodlagos ellenanyagot (R37120, TFS), amellyel 1,5 órán át inkubáltuk szobahőn himbán (letakarva). Ezt követően ismét mostuk 4-szer 10 percig $600 \mu$ l PBST-ben, majd DAPI festéshez rámértünk $600 \mu \mathrm{l}, 2500 x$ hígítású PBST-ben oldott DAPI-t 10 percre, amit 10 perc mosás 
követett $600 \mu \mathrm{l}$ PBST-ben. 1 órát inkubáltuk a mintákat himbán szobahőn $600 \mu \mathrm{l}$ 30\% glicerint tartalmazó PBS-ben, majd 87\%-os glicerinben preparáltuk őket. Fluoromontban helyeztük tárgylemezre a szöveteket, melyekröl a fotókat Olympus BX51 és Olympus FV10i Confocal Laser Scanning mikroszkóppal készítettük. 


\section{Eredmények}

\section{IV.1. A Drosophila Hat1 általános jellemzése és funkciójának vizsgálata a Huntington-kór patogenezisében}

Drosophila melanogasterben a CG2051, vagy Hat1, egy citoplazmatikus hiszton acetiltranszferázt kódoló génként ismert. A harmadik kromoszómán a 83C4 citológiai pozícióban található, mérete 2048 bp. Humán ortológja a Hatl. Muslicában ez az egyetlen eddig azonosított H4 specifikus katalítikus aktivitással rendelkező citoplazmatikus hiszton acetiltranszferáz enzim.

\section{IV.1.1. Hat1 deléciós mutáns elóállítása}

A Hat1 gén funkciójának vizsgálatához a $P\{E P g y 2\} H a t 1^{E Y 21697}$ transzpozon inszerciós Drosophila törzsböl kiindulva P-elem remobilizálással Hatl deléciós mutánst állítottunk elö. A $P\{E P g y 2\} H a t 1^{E Y 21697}$ inszerció a Hat1 első intronjában, a 3R:5.789.135 genomi pozícióban lokalizálódik. A P-elem inszerciós törzs törzs mini-white $\left(\mathrm{w}^{+\mathrm{mC}}\right)$ és mini-yellow $\left(\mathrm{y}^{+\mathrm{mDint2}}\right)$ látható markereket hordoz, továbbá tartalmaz egy Scer/UAS kötőhelyet Scer/GAL4 transzkripciós regulátor általi indukálható expressziót biztosítva. A törzs életképes és fertilis. A P-elem remobilizálást $\Delta 2-3$ transzpozáz forrással végeztük és a transzpozon által hordozott domináns mini-white marker elvesztésére szelektáltunk a revertáns vonalak azonosításához. A revertáns vonalakat ezt követően PCR-ral teszteltük. A Hatl-et érintő deléciók azonosításához olyan primereket terveztünk, amelyek közrefogják a Hat1 kódoló szekvenciáját, de a Hatl-et határoló géneket nem érintik (a primerek az Anyagok és módszerek fejezetben találhatóak). 226 revertáns vonalat teszteltünk, melyek közül 5 hordozott deléciót. Ezek közül az 57-es számú $\left(\mathrm{Hatl}^{457}\right.$ ) bizonyult a legnagyobb méretünek (3. ábra).

A Hat ${ }^{457}$ törzs szekvenálása során kiderült, hogy a deléció a kódoló régió mintegy $80 \%$-át érinti, benne a katalítikus aktivitásért felelős acetiltranszferáz domént is. A 2048 bp-os génből 1409 bp deletálódott, ez a 3R:5.787.709 - 5.789.127 genomi régiót jelenti. A kísérleteink kontrolljaként kiválasztottunk egy precíz revertáns törzset is (amelyben a P-elem kiugrása nem idézett elő deléciót), melynek szekvenciáját kapilláris szekvenálással szintén ellenőriztük. A Hat1 ${ }^{\text {REV16 }}$ revertánsban a P-elem kivágódása során nem távolított el génszakaszt a Hat1 génből, azonban mintegy 20 bázispár hátra maradt a transzpozonból, ami feltehetőleg nem okoz zavart a gén expressziójában és funkciójában. (A deléciós mutáns esetén nem találtunk hátra hagyott P-elem darabot.) 


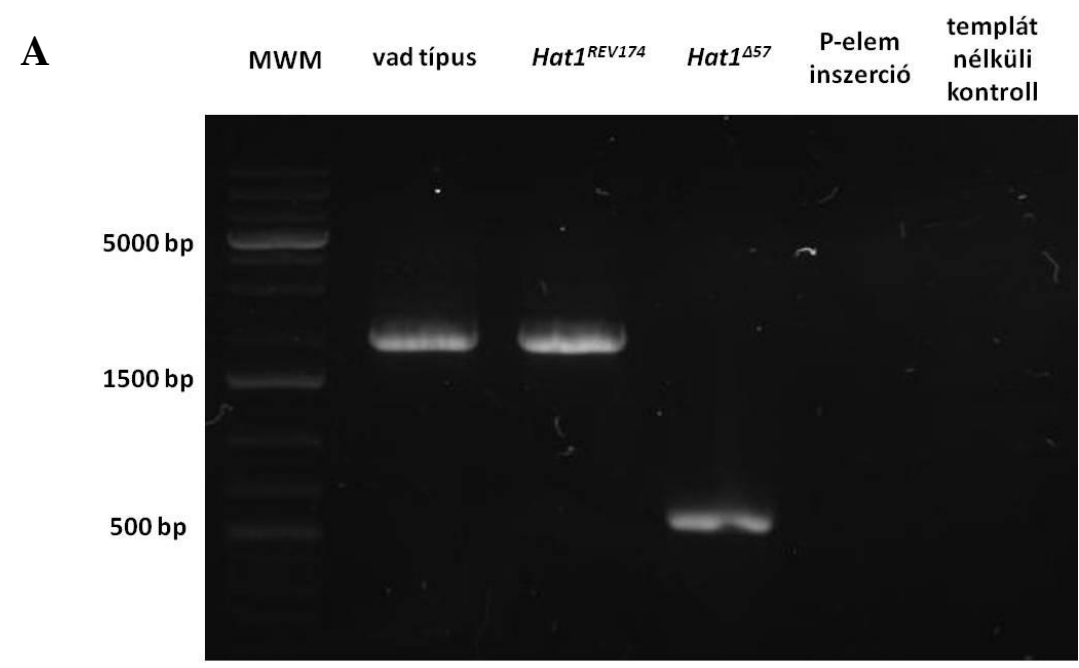

B

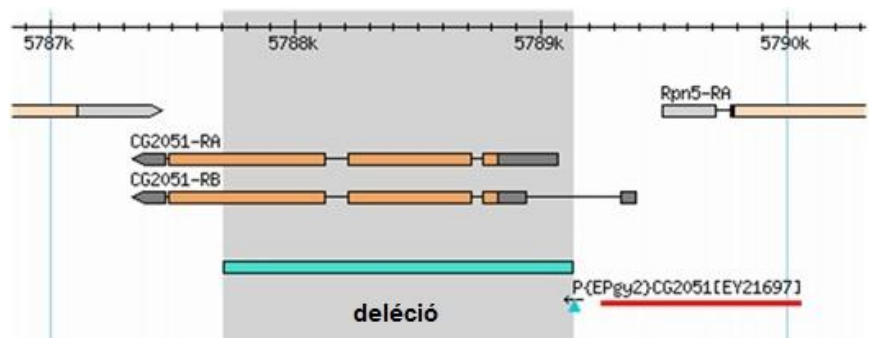

3. ábra. Deléció létrehozása a Hat1 génben P-elem remobilizációval. (A). $w^{1118}$ (Hat1re nézve vad-típusú) törzsből, egy a P-elem remobilizációból származó precíz

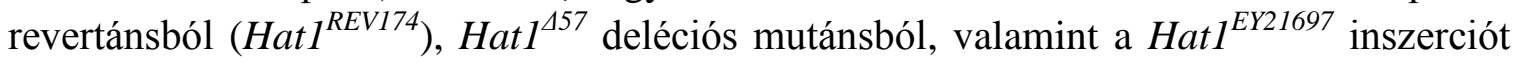
hordozó törzsből izolált genomi DNS mintán végzett Hatl specifikus PCR reakciók termékei láthatóak. A P\{EPgy2\}Hat ${ }^{E Y 21697}$ elemet hordozó törzsön végzett $\mathrm{PCR}$ során nem keletkezett termék a transzpozon túl nagy mérete miatt, míg a Hatl $^{457}$ deléciós mutánson végzett PCR terméke jól láthatóan mintegy $1500 \mathrm{bp}$-al rövidebb a $w^{1118}$ vad típusú, illetve a Hat ${ }^{\text {REV174 }}$ precíz revertáns egyedeken végzett PCR reakciók termékeinél. (B) A Hat1 ${ }^{457}$ deléció genomi kiterjedését (szürke kiemelés) mutató sematikus ábra.

\section{IV.1.2. A Hat1 H4K5 és K12 specifikus acetiltransżeráz aktivitással rendelkezik}

Annak megállapítására, hogy a Drosophila Hat1 humán ortológjához hasonló funkciót tölte be a hiszton fehérjék acetilálásában, western blot kísérleteket végeztünk. A kísérlethez da-GAL4 > Hat $1^{\text {EY21697 }}$ - Hat1 túltermelö, Hat $1^{457}$ homozigóta, valamint kontrollként $w^{1118} 0$ 6 órás embriókból készítettünk fehérjemintát, ugyanis génexpressziós adatok alapján az egyedfejlődés során ekkor a legerősebb a Hat1 gén expressziója ${ }^{288}$.

A western blot kísérletekhez anti-H4K5ac és anti-H4K12ac elsődleges ellenanyagot használtunk, mivel ezek az acetilációs módosítások köthetőek elsődlegesen a Hat1 hiszton acetiltranszferáz ortológokhoz. Bemérési kontrollként anti-H3 ellenanyagot használtunk. A western blot kísérletek jelintenzitásainak értékeit kvatifikáltuk és normalizáltuk a H3 loading kontroll szintjére. A kísérlet során H4K5ac és H4K12ac jel volt detektálható a vad típusú 
$w^{1118}$ és az Hat1 túltermelő mintákban, viszont a Hat $1^{457}$ mutásban nem, vagy csak nagyon kis mértékben. A deléciós mutánsban mért értékek mindkét esetben szignifikánsan kevesebbnek bizonyultak a $w^{1118}$ kontrollban jelen lévőnél (H4K5ac t-próba: $\mathrm{P}=2,88 \times 10^{-5}$, H4K12ac tpróba: $\left.\mathrm{P}=7,265 \times 10^{-3}\right)(4-5$. ábra).

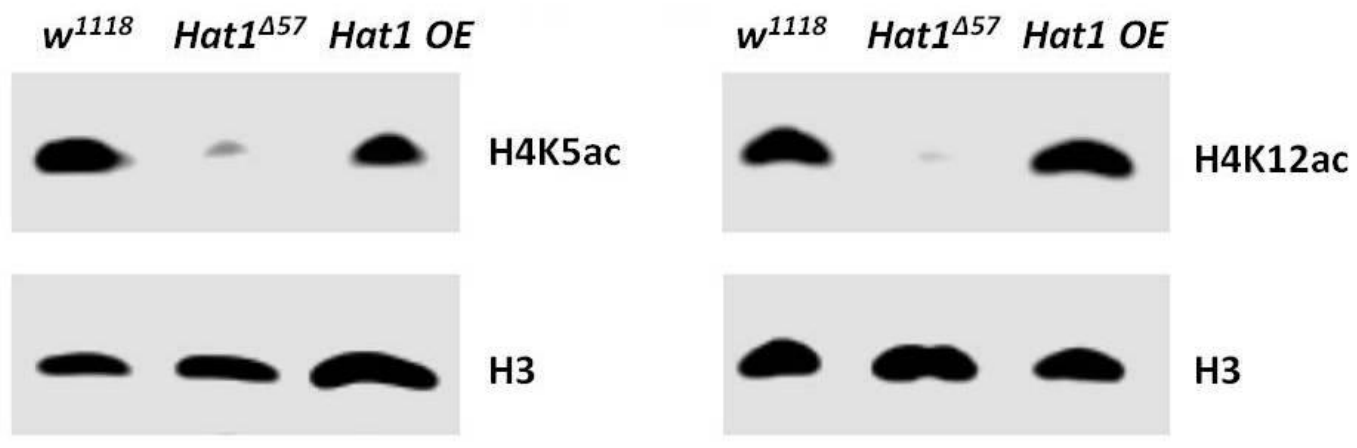

4. ábra. A Hat1 H4K5 és H4K12 acetilációs aktivitással rendelkezik. Reprezentatív western blot képek $w^{1118}$, Hat ${ }^{457}$ és Hat1 túltermelő (overexpressziós - OE) 0-6 órás embrió mintákról. A Hat1 deléció hatására a H4 K5 és K12 acetiláció csaknem eltünik a Drosophila embriókból.

A

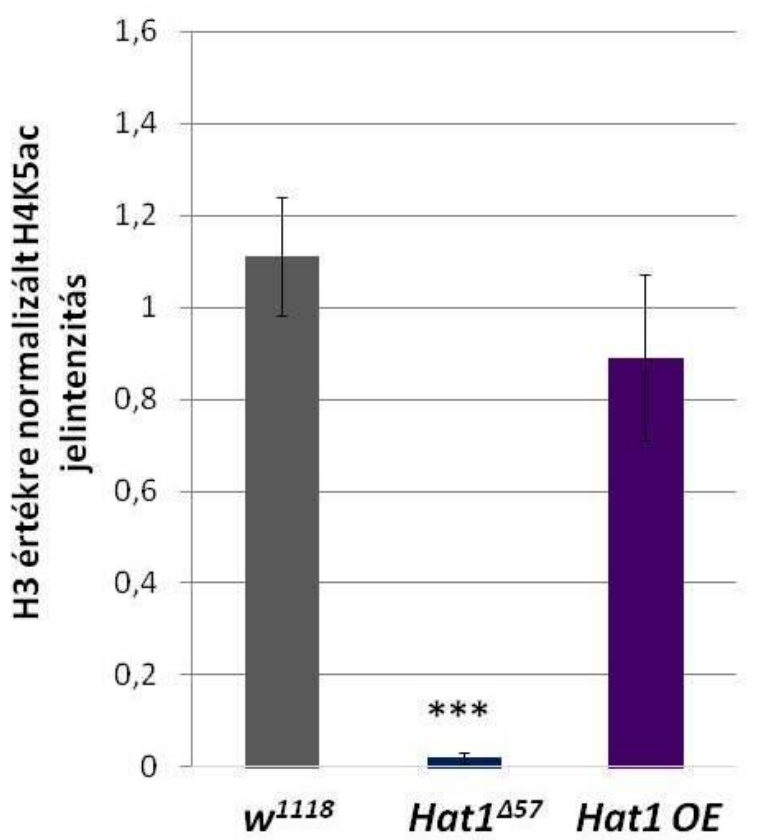

B

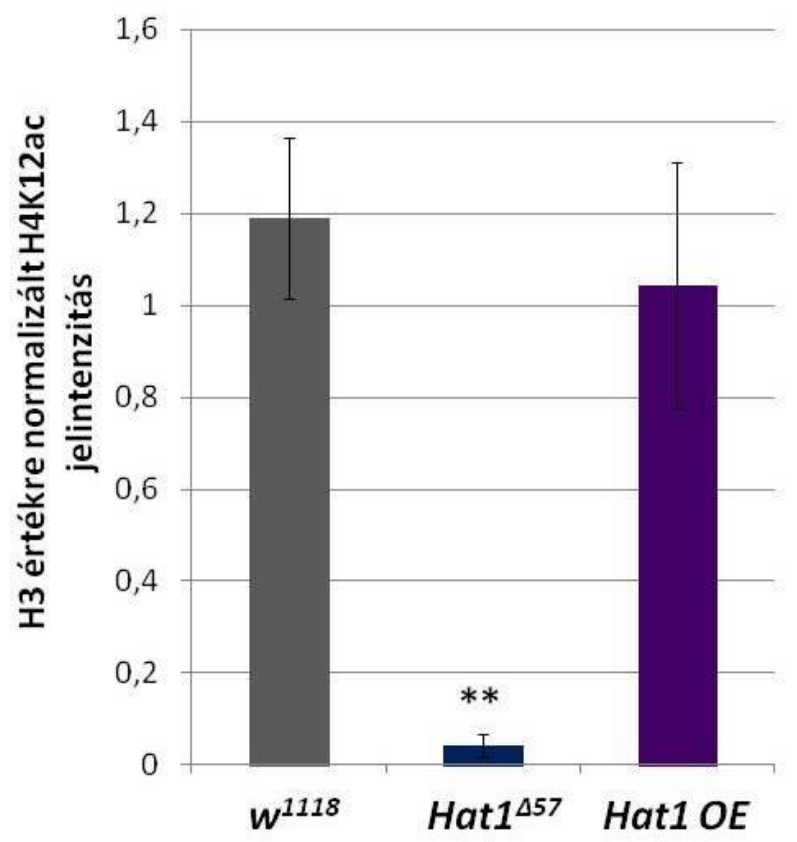

5. ábra. A Hat1 felelős az embrionális H4K5 és H4K12 acetiláció döntő részéért. Western blot kísérlet $w^{1118}$, Hat ${ }^{457}$ és Hat1 túltermelő (overexpressziós - OE) 0-6 órás embrió mintákon. H4K5ac (A) és H4K12ac (B) jelintenzitás értékek összesítésének ábrázolása látható $\mathrm{H} 3$ értékre normalizálva. A diagramokon hibasávként szórás látható feltüntetve. A statisztikai értékelés Student t-próbával történt, ahol a **: P-érték $<0,01$, 
***: P-érték <0,001. A western blot kísérletek eredményeinek összesítése alapján a Hat1 deléció hatására az embrionálisan jelen lévő H4K5 és H4K12 acetiláció szignifikánsan kevebb a vad típusban találhatónál, a Hat1 túltermelése viszont nem eredményez megemelkedett acetilációs szintet.

Annak megállapítására, hogy a Hat1 ortológokra jellemző H4 acetilációs aktivitáson kívül a Hat 1 más pozícióban is acetilálja-e a H4-es hiszton fehérjét, megvizsgáltuk a H4K8 acetilációs szintet is $\mathrm{Hatl}^{457}$ és $w^{1118}$ vad típusú egyedeken. A western blot kísérlet a várakozásainknak megfelelő eredményt adott, a H4K8 acetiláció mértékét a Hat1 deléció nem befolyásolja, vagyis ilyen katalítikus aktivitással nem rendelkezik (6. ábra).

A

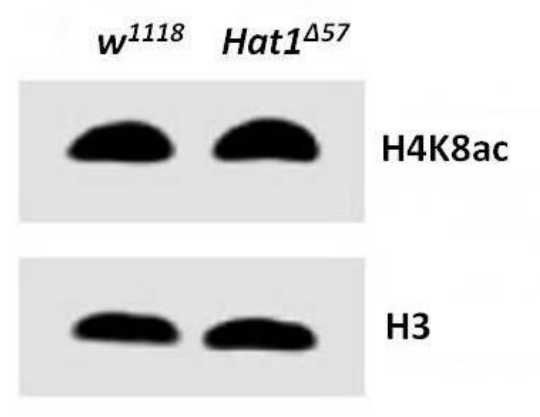

B

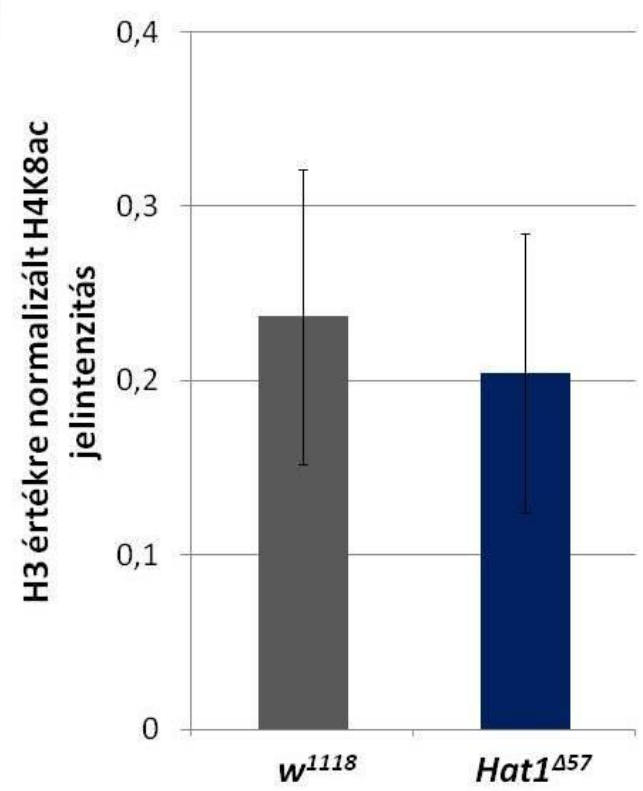

6. ábra. A Hat1 mutánsban nem változik a H4K8 acetiláció mértéke. (A) Reprezentatív western blot kép $w^{1118}$ és Hat $1^{457}$ 0-6 órás embrió mintákról. (B) A western blot H4K8ac jelintenzitás értékek összesítésének ábrázolása. A diagramon hibasávként szórás látható feltüntetve. A Hat1 deléció hatására a H4K8ac szint nem változott szignifikáns mértékben a korai embriókban, tehát a Hat1 katalítikus aktivitása specifikusnak tünik a H4K5 és H4K12 pozíciókra.

Az eredmények alapján elmondható, hogy a Hat1 felelös a H4K5 és H4K12 acetiláció döntő részéért Drosophila embrióban. Katalítikus aktivitása specifikusnak tűnik erre a két pozícióra, ugyanis a $\mathrm{H} 4 \mathrm{~K} 8$ acetilácó szintjében a Hat ${ }^{457}$ embriókban nem történt változás a vad típusú embriókhoz képest.

Megvizsgáltuk a Hat1 deléció hatását a $\mathrm{H} 3$ hisztonon megjelenő acetilációra is, ugyanis irodalmi adatok ${ }^{179}$ alapján egér embrionális fibroblaszt sejtekben a Hat1 hiánya befolyásolta 
a H3 hiszton acetiláltsági állapotát is. Kísérletünk során a H3K18 és H3K23 pozíciók acetilációját teszteltük (7-8. ábra).
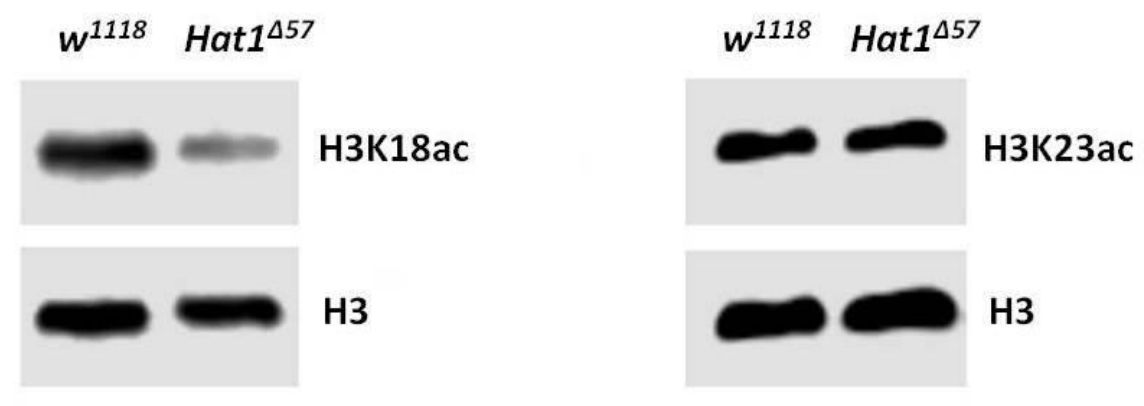

7. ábra. A Hat1 deléció csökkent H3K18 acetilációhoz vezet. Reprezentatív western blot képek $w^{1118}$ és Hat $1^{457}$ 0-6 órás embrió mintákról. A Hatl deléciós embriók csökkent H3K18ac szintet mutatnak a $w^{1118}$ vad típusú embriókhoz képest, míg a H3K23ac szint változatlan marad.

A

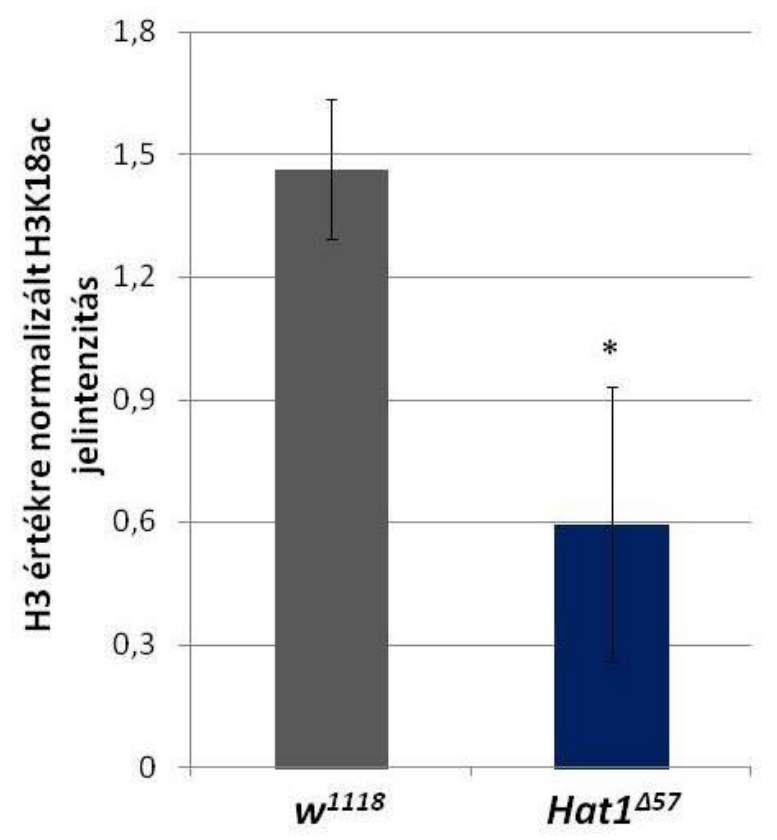

B

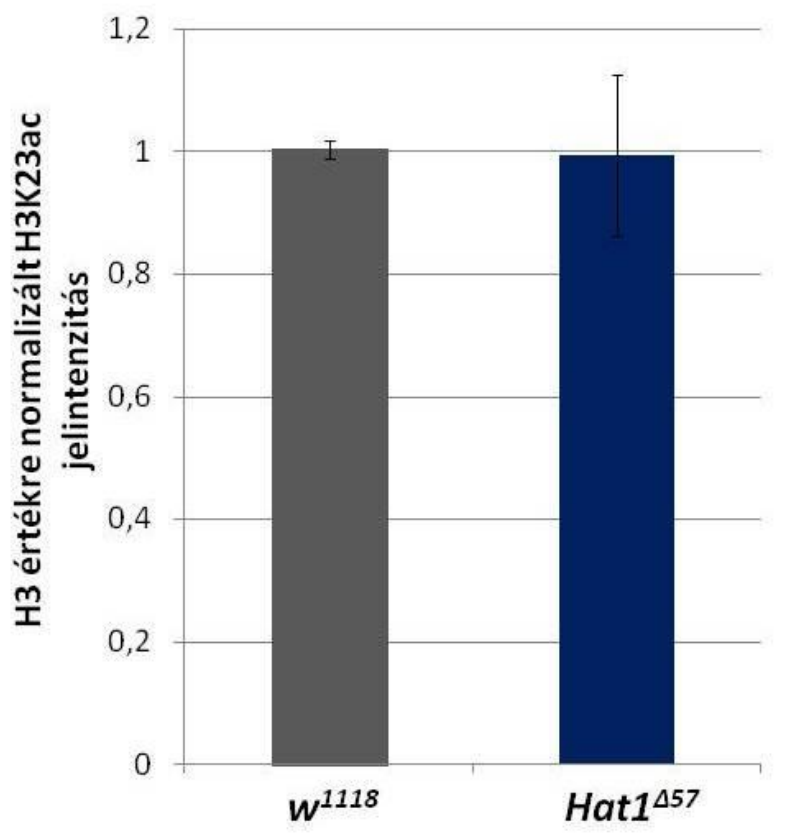

8. ábra. A Hat1 deléció hatással van a H3 hisztonon megjelenő acetilációra. Western blot kísérlet $w^{1118}$ és Hat1 ${ }^{457}$ 0-6 órás embrió mintákon. A H3K18ac (A) és H3K23ac (B) jelintenzitás értékek összesítésének ábrázolása látható $\mathrm{H} 3$ értékre normalizálva. A diagramokon hibasávként szórás látható feltüntetve. A statisztikai értékelés Student tpróbával történt, ahol a *: P-érték < 0,05. A H3K18ac szignifikánsan lecsökken a Hat1 deléciós embriókban a vad típusú $w^{1118}$ kontrollhoz képest, míg a H3K23ac szintben nem található eltérés. 
A H3K23 acetilációs szintben nem volt szignifikáns különbség, azonban a H3K18 acetiláció szintje szignifikáns csökkenést mutatott deléciós mutáns embriókban a vad típushoz képest ( $\mathrm{t}$-próba: $\mathrm{P}=1,61 \times 10^{-2}$ ).

\section{IV.1.3. K5 és K12 acetiláció hiányának hatása a His4r sejtmagi lokalizációjára}

Az újonnan szintetizálódott $\mathrm{H} 4$ hiszton fehérjék a citoplazmában acetilálódnak az Nterminális 5-ös és 12-es lizinjükön, amely módosítások feltételezhetően a sejtmagi transzportban is szerepet játszhatnak. Tekintve, hogy a Hatl deléció hatására szinte eltünik a H4 K5 és K12 acetiláció a korai embriókból, viszont mégsem letális, valószínüsíthető, hogy a H4-es hiszton ezen módosítások hiányában is képes bejutni a sejtmagba.

Ennek igazolására létrehoztunk egy olyan transzgenikus törzset, amely egy indukálható FLAG-tag-gel jelölt His4r konstrukciót hordoz (mivel a His4r aminosav szekvenciája azonos a kanonikus H4 hisztonéval, ezért megkülönböztetésük a peptid tag hozzáadásával lehetséges), amely így nyomon követhető Hat1 homozigóta deléciós háttéren. Továbbá létrehoztunk egy szintén indukálható K5R és K12R dupla módosítást hordozó His4r gént tartalmazó konstrukcióval ellátott transzgenikus törzset is, ahol lizin-arginin cserével lehetetlenné tettük az acetilációt ezekben az pozíciókban, tehát módosítatlan lizineket mimikáltunk a Hat1 targetjeinek számító 5-ös és 12-es pozíciókban.

Ezt követően FLAG specifikus ellenanyaggal végzett lárvális nyálmirigy immunfestéssel vizsgáltuk az acetilálatlan His4r fehérjék lokalizációját egyrészt vad típusú His4r-t Hat1 deléciós háttéren expresszáló (His4r-GB Hat ${ }^{457}$ ), másrészt acetilálhatatlan His4r-t (His4r$K 5 R K 12 R)$ expresszáló lárvális nyálmirigy sejtekben, amelyeket kontrollként vad típusú His4r-t vad típusú háttéren expreszáló (His4r-GB) nyálmirigy sejtekhez hasonlítottunk. A vad típusú kontroll és a két mutáns kategória esetén egyaránt sejtmagi lokalizációt mutat a His4r fehérje. Tehát a H4 K5 és K12 acetilációs módosítások nem nélkülözhetetlenek a nukleáris transzporthoz (9. ábra). 


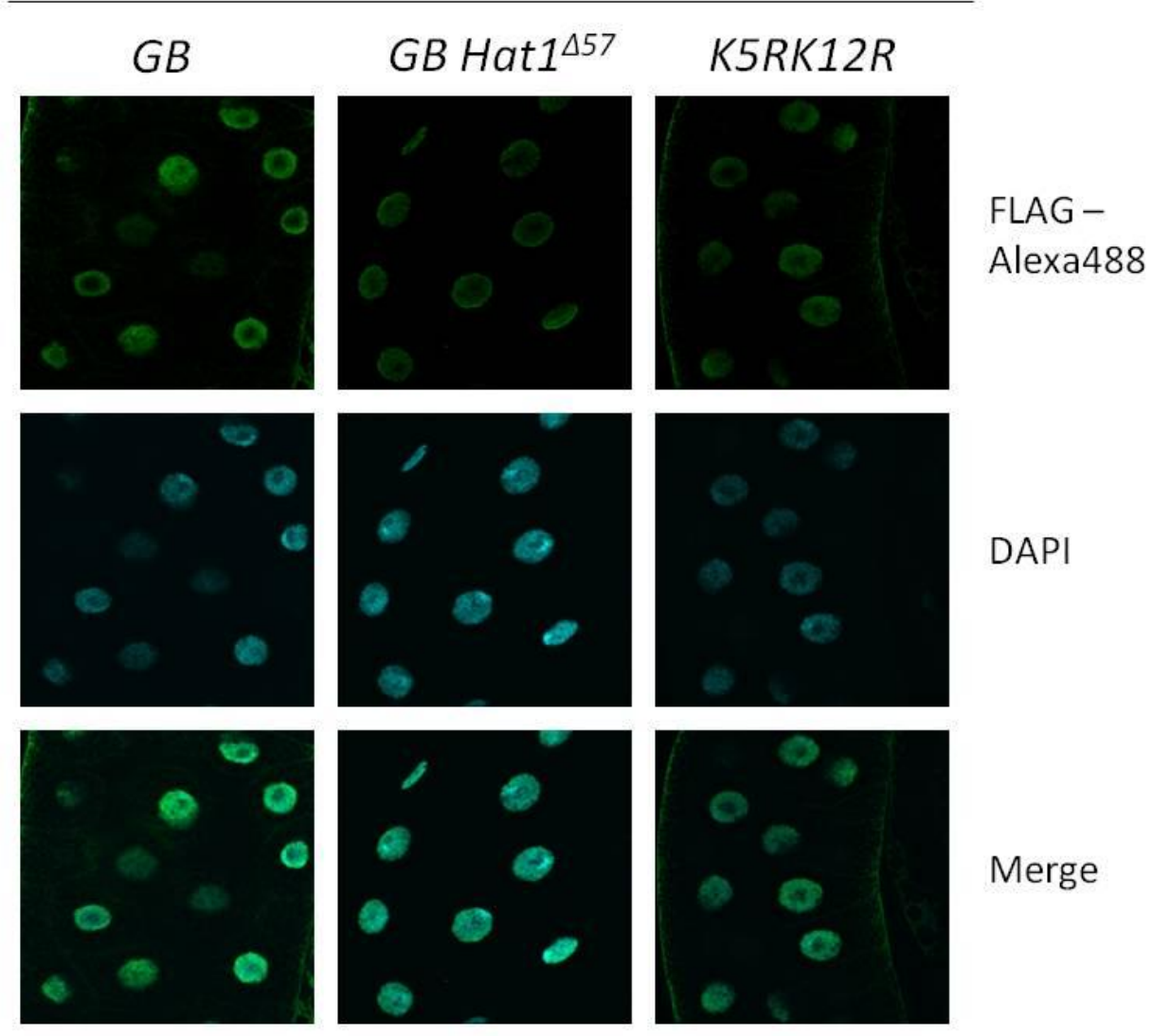

9. ábra. A H4-K5K12 acetiláció nem szükséges a nukleáris importhoz. Konfokális mikroszkóppal készített fotók vad típusú His4r transzgént expresszáló (hs-GAL4/+; UAS$\underline{\text { His } 4 r-G B /+)}$, homozigóta $H a t 1^{457}$ háttéren vad típusú His $4 r$ transzgént kifejező (hs-GAL4/+; UAS-His4r-GB/Hat ${ }^{457}$ ), valamint His4r-K5RK12R transzgént expresszáló (hs-GAL4/+; UAS-His4r-K5RK12R/+) L3-as lárvák nyálmirigyéröl anti-FLAG antitest festéssel (zöld). DAPI festéssel (kék) láthatóak a sejtmagok. A DAPI és FLAG festés teljesen átfed egymással, vagyis a His4r transzgenikus fehérjék minden genotípusban sejtmagi lokalizációt mutatnak.

\section{IV.1.4. A Hat1 deléció csökkent életképességet és élettartamot eredményez}

A Hat1 deléciót hordozó állatokból sikerült homozigóta törzset létrehozni, tehát a deléció homozigóta formában életképes és fertilis. Azonban tesztelni kívántuk, hogy a gén hiánya nem okoz-e csökkent életképességet.

A kérdés megválaszolásához homozigóta $\mathrm{Hatl}^{457}$ állatokat kereszteztünk $\varphi X 86 \mathrm{Fb}$ (a harmadik kromoszómán markerelt, a Hatl génre nézve vad típusú) muslicákhoz és a heterozigóta hím utódokat visszakereszteztük homozigóta deléciós nőstényekhez. A keresztezésből származó Hat1 ${ }^{457}$ homozigóta és heterozigóta utódok kikelési arányát hasonlítottuk össze szemszínük alapján. A kísérlet kontrolljaként ugyanezt a keresztezési 
sémát elvégeztük a $\mathrm{Hatl}^{\text {REV16 }}$ precíz revertáns vonallal is. A kikelési arányok százalékos megoszlását vizsgáltuk külön nőstények és hímek esetén (10. ábra).

A

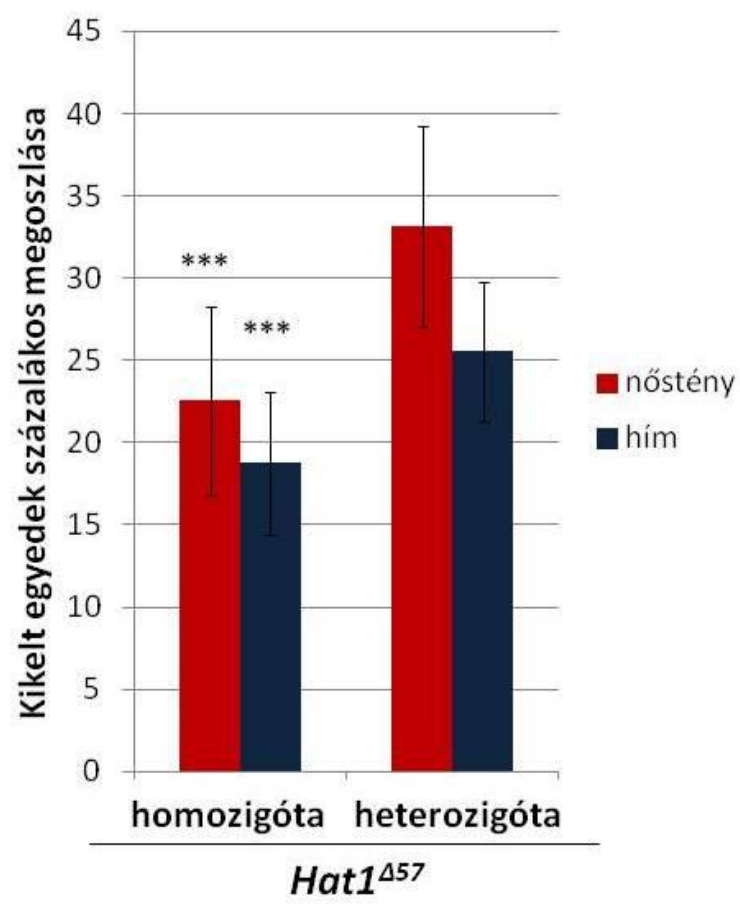

B

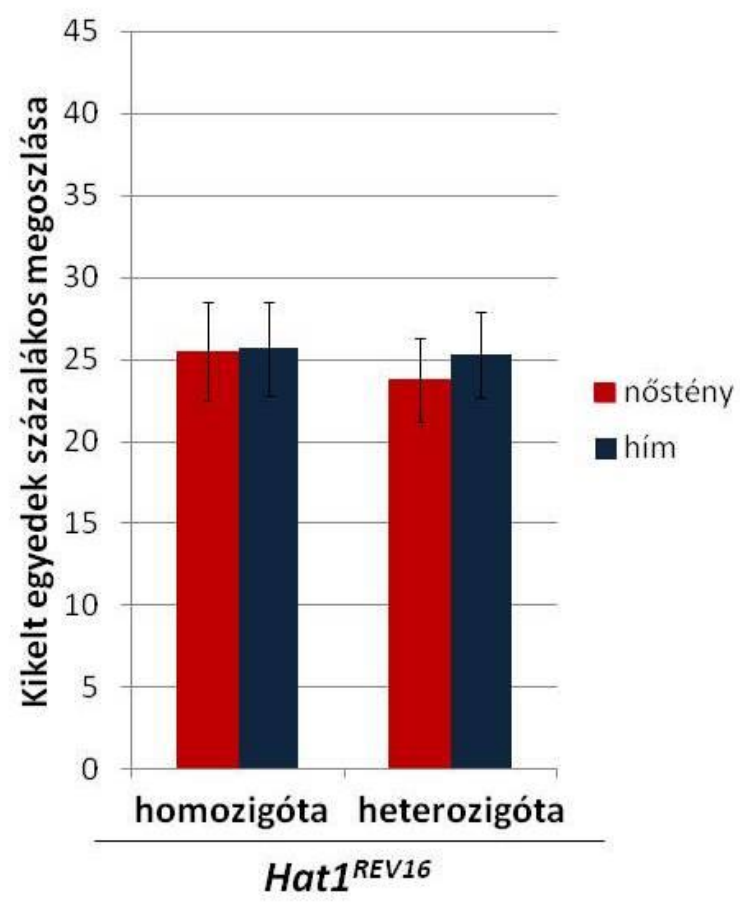

10. ábra. A Hatl deléció csökkenti az életképességet. Homozigóta és heterozigóta Hat $^{457}$ deléciós (A) és Hat1 ${ }^{\text {REV16 }}$ revertáns (B) állatok kikelési aránya. A diagramokon hibasávként szórás látható feltüntetve. A statisztikai értékelés Student t-próbával történt, ahol a ***: P-érték $<10^{-4}$. A Hat ${ }^{457}$ delécióra heterozigóta és homozigóta egyedeknél egyaránt nagyobb arányban keltek nőstény utódok, mint hímek, azonban a delécióra homozigóta utódok kikelési aránya szignifikánsan kevesebbnek bizonyult a heterozigótákénál, mind a hímek, mind a nőstények esetén. A Hat ${ }^{\text {REVI6 }}$ precíz revertáns esetén a kikelési arányokban nem volt eltérés.

A kísérletekböl egyértelmüen kiderül, hogy a Hatl deléció ront az egyedek életképességén. A Hat $^{457}$ delécióra homozigóta utódok kikelési aránya mind nőstények (t-próba: $\mathrm{P}=$ $\left.1,593 \times 10^{-6}\right)$, mind hímek ( $\mathrm{t}$-próba: $\mathrm{P}=1,186 \times 10^{-5}$ ) esetén szignifikánsan lecsökkent a delécióra heterozgótákhoz képest, míg a Hat ${ }^{\text {REVI6 }}$ precíz revertáns esetén nincs szignifikáns különbség a kikelési arányokban.

A Hat1 deléció okozta életképességben bekövetkezett csökkenés hatására kíváncsiak voltunk, vajon az élettartamban is tapasztalható-e változás a precíz revertánshoz képest. Az élettartam vizsgálatot Hat $^{457}$ és Hat ${ }^{\text {REVl6 }}$ homozigóta egyedeken végeztük. Az élettartam görbék eltérései a nőstények esetén a 25, 50, 75 és 90\%-os mortalitási értéknél egyaránt (Pérték: $25 \%$ - 0,0001, 50\% - 0,000022, 75\% - 0,0002, 90\% - 0,0008), hímeknél pedig a 90\%-os érték kivételével (P-érték: $25 \%-5,7 * 10^{-9}, 50 \%-4,8^{*} 10^{-7}, 75 \%-0,0001,90 \%-0,1198$ ) 
szignifikánsnak bizonyultak (11. ábra és 1. táblázat). Eredményeink alapján tehát a Hat1 deléció nem csak az életképességre, hanem az élettartamra is szignifikánsan negatív hatással van.
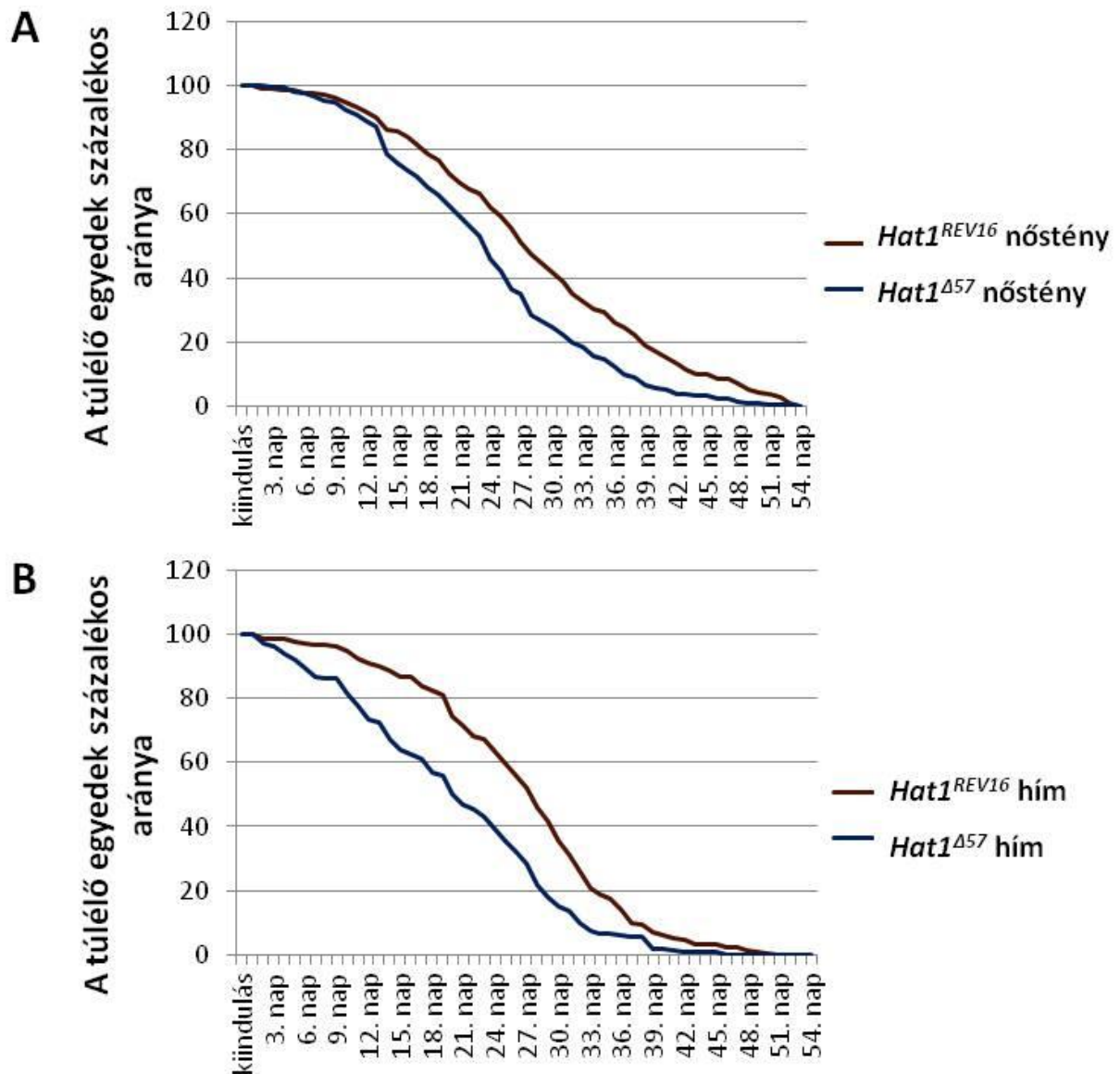

11. ábra. A Hat1 deléció csökkent élettartamot okoz. Hat1 ${ }^{457}$ és Hat1 ${ }^{\text {REV16 }}$ egyedek élettartam görbéi százalékos értékeket feltüntetve, nőstényeket és hímeket külön-külön ábrázolva láthatóak. Az élettartam görbék lefutásában szignifikáns különbségek láthatóak a deléciós mutánsok és a revertáns kontroll között a nőstényeknél és a hímeknél egyaránt Log-Rank Teszt alapján a különbség szignifikancia értéke nőstények esetén $\mathrm{P}=1,5 \times 10^{-5}$, hímek esetén $\mathrm{P}=1,9 \times 10^{-7}$.

\begin{tabular}{|c|c|c|c|c|}
\hline Összehasonlított genotípusok & $\begin{array}{c}\text { P-érték 25\%-oS } \\
\text { mortalitásnál }\end{array}$ & $\begin{array}{c}\text { P-érték 50\%-oS } \\
\text { mortalitásnál }\end{array}$ & $\begin{array}{c}\text { P-érték 75\%-0S } \\
\text { mortalitásnál }\end{array}$ & $\begin{array}{c}\text { P-érték 90\%-0S } \\
\text { mortalitásnál }\end{array}$ \\
\hline Hat1 $^{\Delta 57}$ v.s. Hat1 ${ }^{\text {REV16 }}$ nöstény & 0,0001 & 0,000022 & 0,0002 & 0,0008 \\
\hline Hat1 $^{\Delta 57}$ v.s. Hat1 ${ }^{\text {REV16 }}$ hím & $5,7^{*} 10^{-9}$ & $4,8^{\star} 10^{-7}$ & 0,0001 & 0,1198 \\
\hline
\end{tabular}

1. táblázat. A Hat1 ${ }^{457}$ és $H_{a t 1}{ }^{R E V 16}$ egyedek meghatározott mortalitási arányaihoz tartozó szignifikancia értékek. A hímek és nőstények adatai külön-külön kerültek értékelésre. Piros színnel kiemelve láthatóak a szignifikáns eltérések. Az értékelés Mann Whitney U Teszttel történt. 
A hímeknél a 90\%-os mortalitási értéknél nem volt szignifikáns az eltérés a Hat1 ${ }^{\text {REV16 }}$ kontroll és a Hat $^{457}$ deléciós egyedek között, azonban a többi mortalitási értéknél nagyobb mértékủ és szignifikánsabb különbségeket figyelhetünk meg, mint a nőstények esetén.

\section{IV.1.5. A Hat1 nem szükséges a fertilitáshoz, de a túltermelése nöstényekben megnöveli a lerakott peték számát}

A gén a reproduktív szervekben mutatja a legmagasabb expressziós szintet a modeENCODE szövetexpressziós adatok szerint ${ }^{289}$, ezért fekunditás tesztet végeztünk az állatok termékenységének vizsgálatára. A kísérlet során $H_{a t} 1^{457}$ mutáns és da-GALA > Hat1 ${ }^{\text {EY21697 }}$ - Hat1 túltermelő állatokat, kontrollként pedig Hat ${ }^{\text {REV16 }}$ precíz revertáns törzset használtunk. Mind a három kategóriából szűz nőstényeket $w^{1118}$ vad típusú hímekkel kereszteztünk, majd meghatároztuk a 24 óra alatt lerakott peték számát. A 24 órás petézések eredményét átlagoltuk egy nőstényre (12. ábra). Az eredményekből az a következtetés vonható le, hogy a Hat1 hiánya nincs hatással a fekunditásra, viszont túltermelése esetén szignifikánsan ( $\mathrm{t}$-próba: $\mathrm{P}=8,92 \times 10^{-9}$ ) megemelkedik a lerakott peték száma.

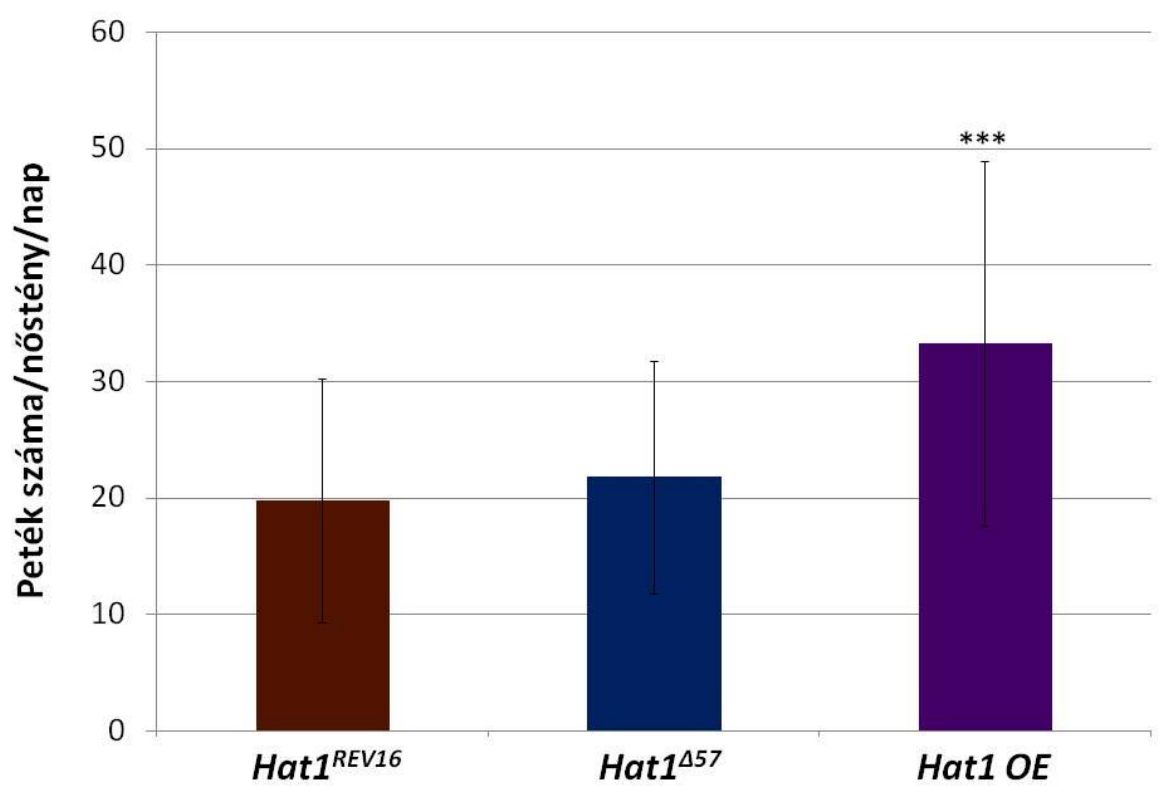

12. ábra. A Hat1 túltermelése esetén megemelkedik a nőstények által rakott peték mennyisége. Fekunditás teszt a Hat1 ${ }^{\text {REV16 }}$, a Hat1 ${ }^{457}$ és Hatl túltermelő (overexpresszáló - OE) nőstényeken. Az eredmények 5 nap összevont átlagából származnak a három vizsgált kategóriára és az egy nőstény által egy nap alatt lerakott peték számát ábrázolja. A diagramokon hibasávként szórás látható feltüntetve. A statisztikai értékelés Student tpróbával történt, ahol a $* * *$ : P-érték $<10^{-8}$. Míg a Hatl deléció szemmel láthatóan nem volt különösebb hatással a nőstények fekunditására, addig a túltermelése szignifikánsan növelte a lerakott peték számát. 


\section{IV.1.6. A Hat1 gén neuronális kifejezödésének vizsgálata az öregedés során}

Mivel egyes hiszton acetiltranszferázok aktivitásáról bizonyított, hogy szerepet játszanak az öregedés és a neurodegeneráció folyamatában 290195 52, kíváncsiak voltunk, hogy az öregedés során változik-e a Hatl transzkripciós aktivitása az idegsejtekben. A vizsgálathoz a Hat1-re nézve vad típusú $w^{1118}$ muslica öregedési soron (1 napos, 3 napos, 1 hetes, 2 hetes és 6 hetes), fejekből izolált RNS-ből készítettünk cDNS mintát, majd ezeken expressziós mérést végeztünk qPCR-al Hatl specifikus primerekkel. Az eredmények alapján elmondható, hogy közvetlenül a kikelést követően a Hat1 transzkriptum mennyisége jelentősen megemelkedik, nagyjából a kétszeresére, majd ebben a transzkriptum mennyiségben ezt követően az öregedés első 6 hete során nem következik be szignifikáns változás (13. ábra).

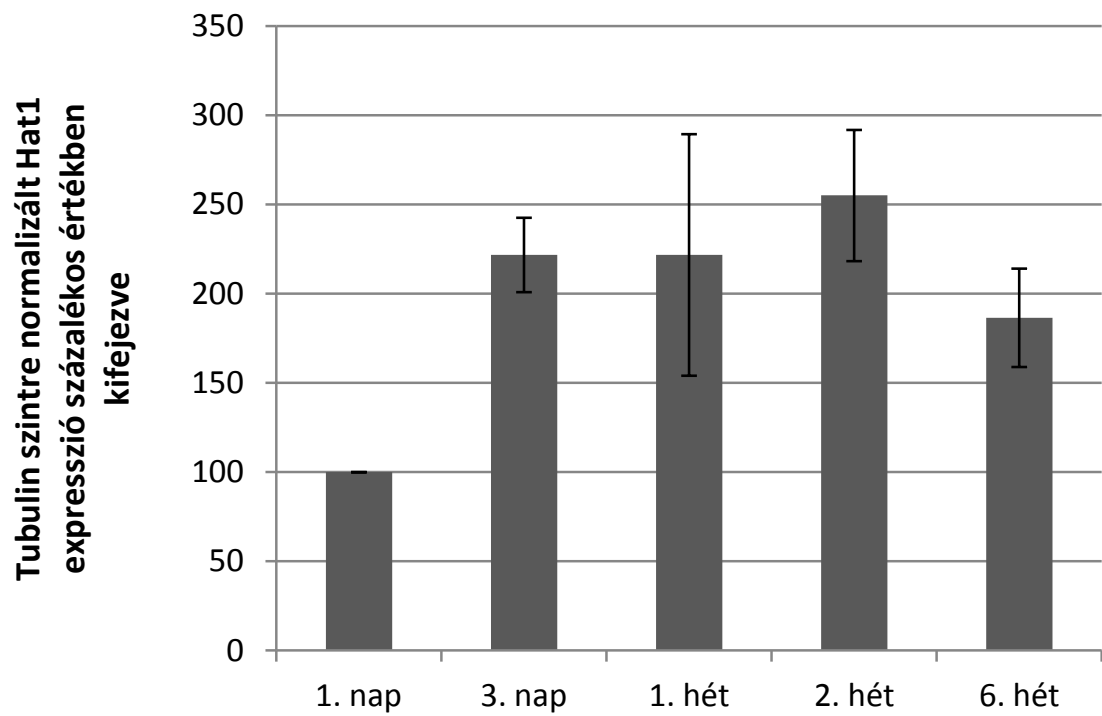

13. ábra. A Hat1 mRNS neuronális szintje egyenletes az öregedés során. Hat1 neuronális expresszió vizsgálata RT-qPCR-ral $w^{1118}$ vad típusú muslica öregedési soron tubulin szintre normalizálva. A diagramokon hibasávként szórás látható feltüntetve. A Hat1 expressziós szintje az 1. nap után megemelkedik, de ezt követően egy viszonylag állandó értéket mutat az öregedés első 6 hete során.

\section{IV.1.7. A Hat1 gén deléciojjának hatása a napi aktivitásra és cirkadián ritmusra}

A hiszton acetitranszferázok nem megfelelő müködése esetén fellépő neurodegeneratív folyamatok egyik tünete a cirkadián ritmus zavarok megjelenése. ${ }^{291}{ }^{52}$ Kíváncsiak voltunk, vajon a föként citoplazmatikus Hat1 enzim befolyásolja-e a cirkadián ritmust és napi motoros aktivitást. Ennek megválaszolására egy hetes hím Hat $^{457}$ egyedeken végeztünk vizsgálatot, kontrollként Hat ${ }^{\text {REVl6 }}$ precíz revertáns törzset használtunk. A vizsgálatokat DAM-2 Drosophila aktivitás monitorral (TriKinetics Inc, Waltham, MA USA) végeztük, amely 
infravörös sugár segítségével érzékeli a detektor elött elhaladó állatokat. Az eredmények azt mutatják, hogy a Hat $^{457}$ deléciós mutáns egyedek cirkadián ritmusában nem következik be lényeges változás, azonban kis (statisztikailag nem szignifikáns) mértékben csökkent aktivitást és emelkedett alvás mennyiséget mutatnak a Hat1 ${ }^{\text {REV16 }}$ revertáns kontroll egyedekhez képest (14-15. ábra).

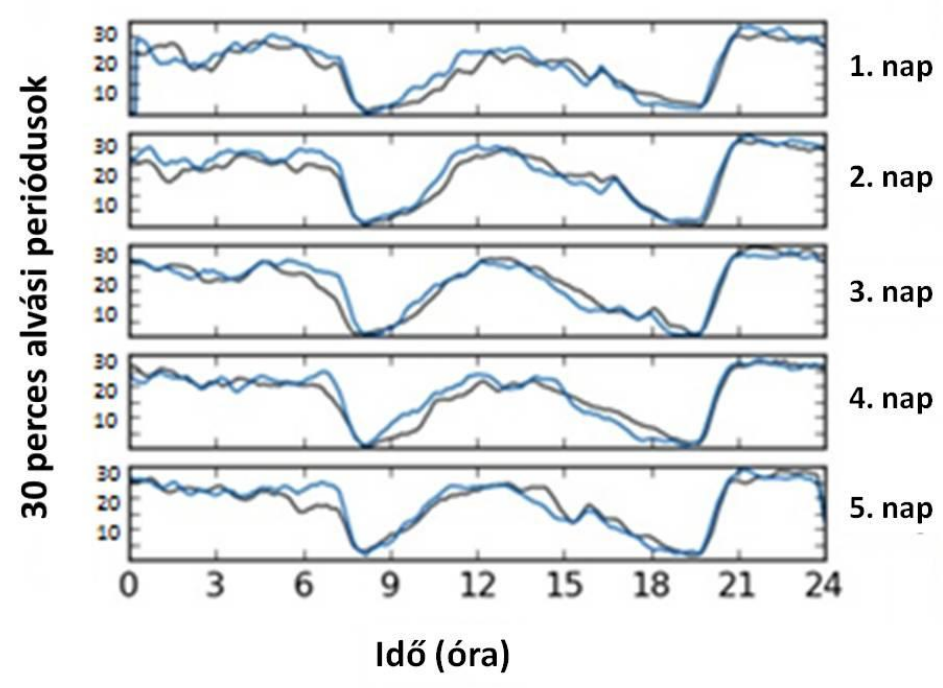

14. ábra. A Hat1 deléció nincs hatással az egyedek cirkadián ritmusára. Az ábrán öt napon keresztül látható a vizsgált egyedek aktivitása. A mérés 12-12 órás fény-sötét megvilágításban történt, ahol reggel 8 órától este 8 óráig tartott a megvilágítás. Feketével ábrázolva látható a Hat1 ${ }^{R E V 16}$ precíz revertáns kontroll muslicák aktivitási görbéje, míg kékkel jelölve a Hat1 $^{457}$ deléciós mutánsoké. Az ábrán az alvással töltött idő mennyiségek láthatóak 30 perces periódusokban ábrázolva. Mikor reggel 8 órakor felkapcsol a világítás az állatok egy időre felébrednek, illetve előtte és utána is viszonylag éberebbek. Este 8 óránál, mikor a lámpák lekapcsolnak szintén ez figyelhető meg. Az alvással és ébren töltött időszakok lefutása a Hatl deléciós egyedek esetén nem mutat jelentős eltérést a revertáns kontrollhoz képest. 

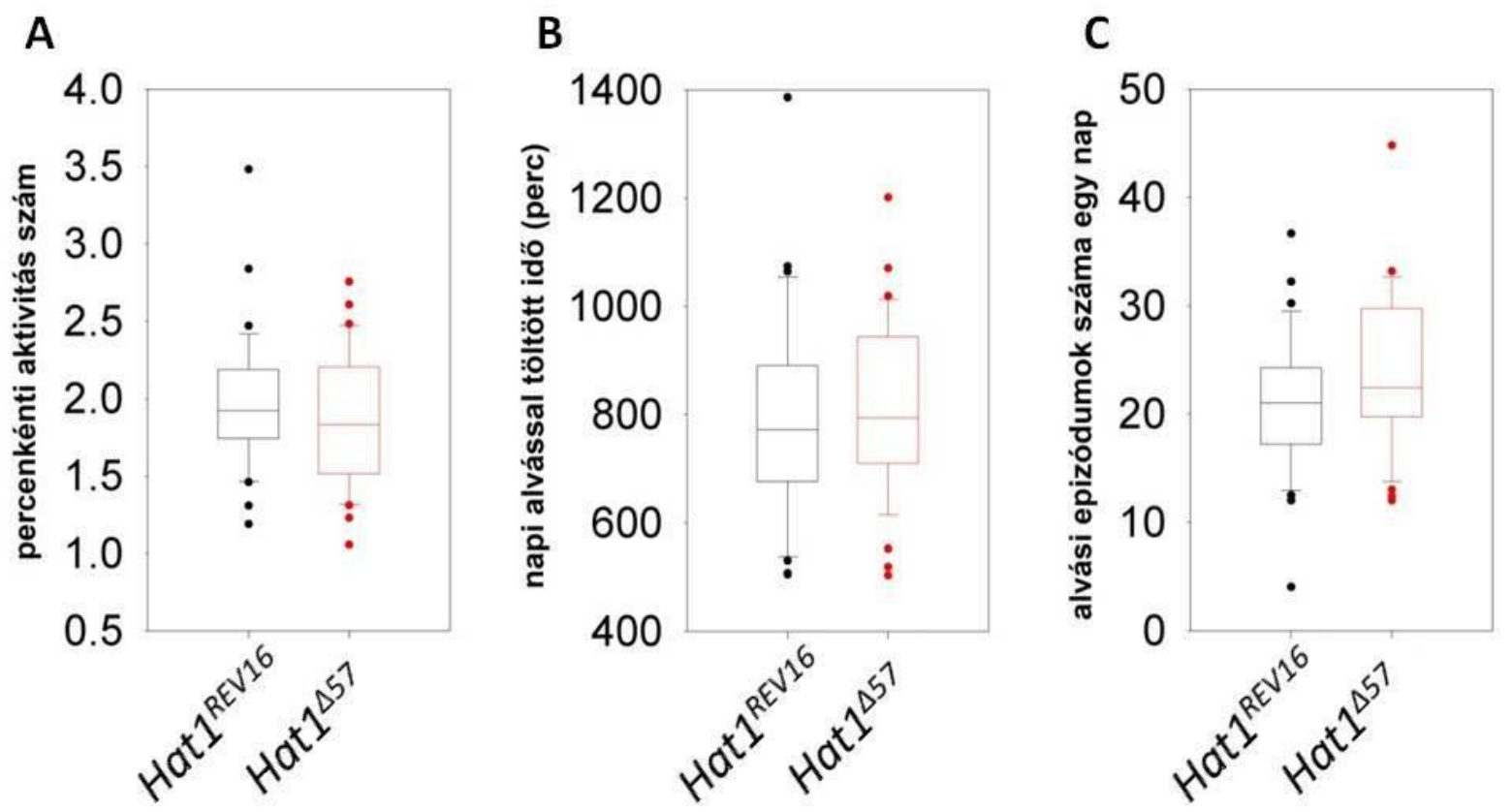

15. ábra. A Hat1 hiányának a napi aktivitásra és alvásra gyakorolt hatása. (A) A Hat $^{\Delta 57}$ és Hat ${ }^{\text {REV16 }}$ egyedek percenkénti aktivitása látható összesítve, amelyből látható, hogy a deléciós mutánsok valamelyest kevésbé aktívak. (B) A Hatl ${ }^{457}$ és Hatl ${ }^{\text {REVlo }}$ egyedek naponta alvással töltött ideje látható percben összesítve, amely alapján a deléciós mutánsok átlagosan több időt töltenek alvással. (C) A Hat1 ${ }^{\Delta 57}$ és Hat1 ${ }^{\text {REVl6 }}$ egyedek alvási epizódumait ábrázolja egy napra átlagolva, amelyből kiderül, hogy a deléciós mutánsok nem csak több időt töltenek alvással, de az alvási epizódumaik száma is több naponta a revertáns kontroll egyedekhez képest. A diagramokon a box a 25 . és 75 . percentilis értéket, valamint a medián értéket jelöli, a hibasávok a 10. és 90. percentilis értékeket mutatják, továbbá pontokként láthatóak az ezen kívül eső adatpontok.

\section{IV.1.8. Kromatin szervezödésre gyakorolt hatás vizsgálata PEV analizissel}

Mivel a hiszton acetiltranszferázok elsősorban a hiszton fehérjék poszttranszlációs módosításában vesznek részt, ezért azok kromatinba épülésére is hatással lehetnek, vagyis kromatin szervező funkciójuk lehet. Ennek vizsgálatára a pozíció effektus variegáció (PEV) jelenségét használtuk fel. Ehhez egy olyan törzset $\left(w^{m 4 h}\right)$ használtunk, amelyben a $w$ szemszín gén heterokromatikus környezet közelébe van helyezve. Ha a heterokromatin ráterjed a $w$ génre, az állatok mozaikos szemében fehér foltok jelennek meg, míg ha a $w$ eukromatikus környezetben marad, akkor a szemben a piros szín dominál. A Hat $1^{457}$ törzsből hím egyedeket kereszteztünk $w^{m 4 h}$ szüz nőstényekhez és az utódok szemszínén vizsgáltuk a változásokat a szem pigment tartalmának fotometrálásával. Kontrollként Hat1 ${ }^{\text {REV16 }}$ precíz revertánst használtunk szintén $w^{m 4 h}$ szűz nőstényekhez keresztezve.

A Hat1 ${ }^{457}$ deléciót hordozó nőstény utódok szemszíne szignifikánsan sötétebb lett, mint a Hat $1^{\text {REV16 }}$ allét hordozó kontrollé, míg a deléciós hímek szemszíne megegyezik a kontolléval (t-próba: nőstények estén $\mathrm{P}=1,62 \times 10^{-4}$; hímeknél $\left.\mathrm{P}=0,694\right)$. Az alábbi eredmények alapján 
a gén deléciójának hatása a nőstény egyedekben variegáció szupresszió volt, a heterokromatin visszahúzódott, vagyis a gén részt vehet a zárt kromatin szerkezet kialakításában és/vagy fenntartásában (16-17. ábra).

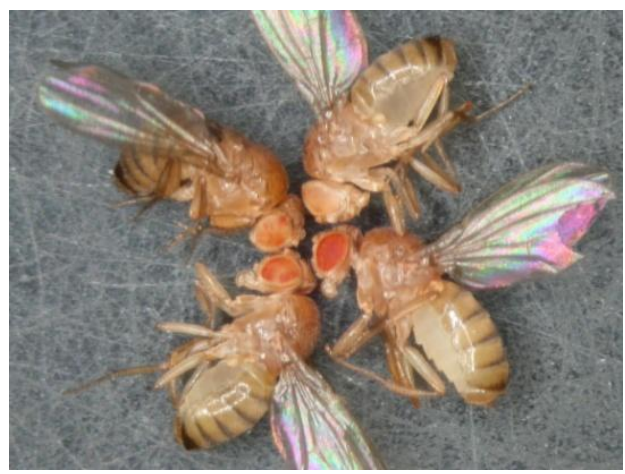

16. ábra. A Hat1 hatással van a kromatin nyitottságra. A PEV szemszínre gyakorolt hatását szemléltető fotó, a képen $w^{m 4 h} / w ;+; \operatorname{Hatl}^{R E V 16} /+$ (felül) és $w^{m 4 h} / w ;+; \mathrm{Hatl}^{457} /+$ (alul) genotípusú egyedek mozaikos szeme látható. Hat1 deléció hatására az egyedek szeme sötétebb színủ a kontrollnál.

A

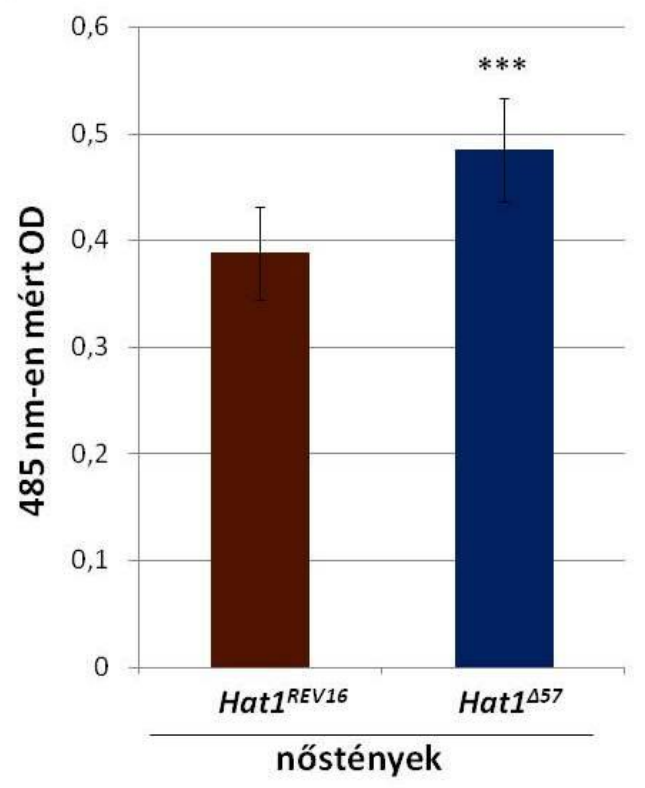

B

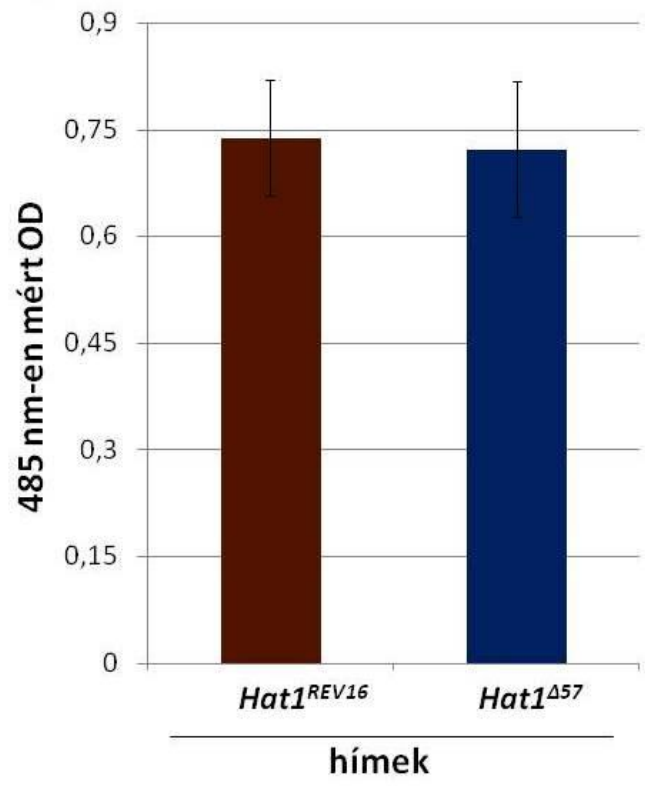

17. ábra. A Hat1 PEV szupresszor hatású nőstényekben. PEV vizsgálat $w^{m 4 h} / w ;+$; Hat1 $1^{457} /+, \quad w^{m 4 h} / Y ; \quad+; H a t 1^{457} /+$, valamint $w^{m 4 h} / w ;+; H a t 1^{R E V 16} /+, w^{m 4 h} / Y ; \quad+$;

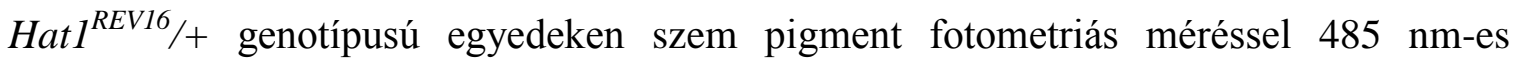
hullámhosszon, a nőstényeket (A) és hímeket (B) külön-külön összehasonlítva. A diagramokon hibasávként szórás látható feltüntetve. A statisztikai értékelés Student tpróbával történt, ahol a ***: $\mathrm{P}<0,001$. A hímek esetén nem látható eltérés, azonban a nőstények szemszíne sötétebb volt a Hatl deléciót hordozó egyedek esetén a revertáns allélt hordozó kontrollnál. Vagyis a deléció hatására a kromatin nyitottabbá vált. 


\section{IV.1.9. A Hat1 deléció transzkriptomikai hatásának vizsgálata}

Tekintve, hogy a PEV teszt során azt az eredményt kaptuk, hogy a Hat1 szerepet játszhat a kromatin szerveződésben, kíváncsiak voltunk, hogy milyen hatásással van a génkifejeződésre és milyen típusú gének expresszióját befolyásolja. Ennek megállapítására polyA-RNS szekvenálást végeztünk Hat $^{457}$ és $w^{1118}$ vad típusú 6-12 órás embrió mintákon. Az eredményekből megállapítottuk, hogy 2137 gén expressziós mintázata változott meg szignifikánsan Hat1 deléció hatására. Ezen expressziós változások 2/3-a génexpresszió növekedést (upregulációt), 1/3-a pedig génexpresszió csökkenést (downregulációt) mutatott.

További elemzés alá vetve a változást mutató géneket, összahasonlítottuk azokat a modENCODE fejlődési RNS expressziós adatokkal. ${ }^{292}{ }^{289}$ Ennek során azt találtuk, hogy a deléciós mutánsban emelkedett expressziót mutató (upregulálódott) gének döntő része vad típusú embriókban egy a vizsgált 6-12 órás fejlődési periódusnál korábbi embrionális stádiumban mutat magasabb expressziót, míg a vad típushoz képest alacsonyabb expressziót mutató (downregulálódott) gének jelentős többsége korábbi embrionális stádium során alacsonyabb szinten expresszálódik. Ebből arra következtetünk, hogy Hat1 deléció hatására egy fejlődési késés következik be az embriókban (18. ábra). 


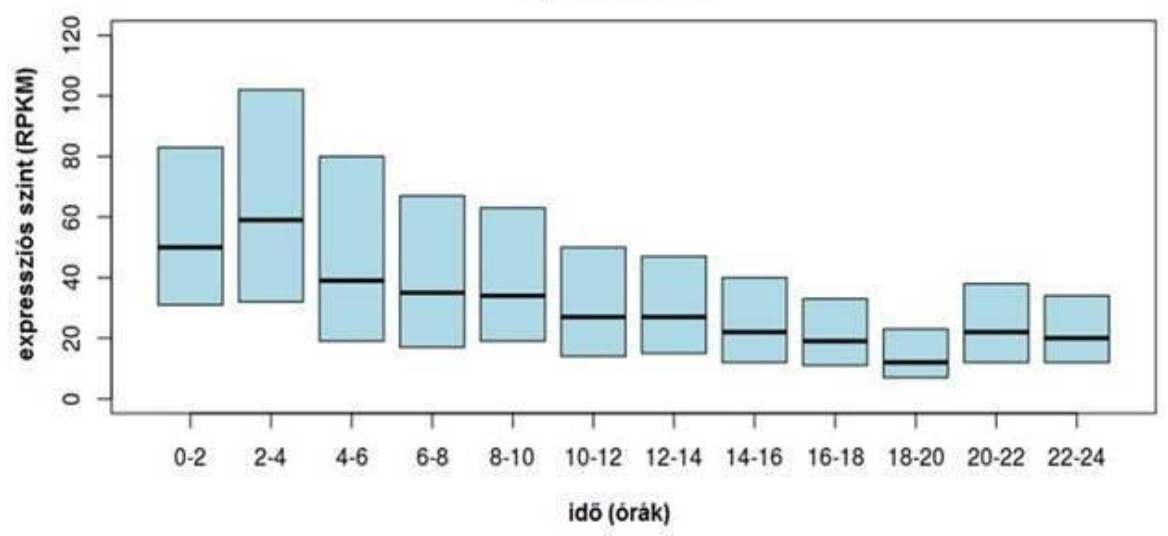

B

Hat1 ${ }^{\Delta 57}$ downregulált gének expressziója vad típusú embrionális fejlődés során

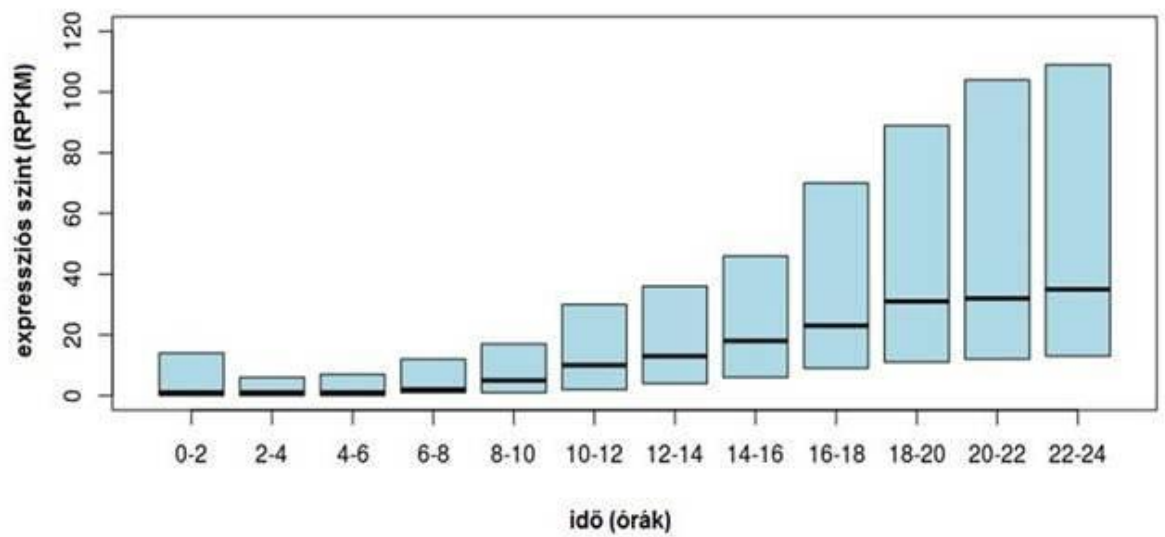

18. ábra. A Hat1 deléció fejlődési késést okoz embriókban. A 6-12 órás Hat ${ }^{457}$ és $w^{1118}$ vad típusú embriók RNS szekvenálás eredményeinek összesítése összevetve a modENCODE RNS-seq adatokkal. ${ }^{292} 289$ A boxplot az adott géncsoportnak vad típusú állatokban mért mediánját valamint első és harmadik kvartilisét mutatja az embrionális fejlődés során. A Hat1 mutánsban emelkedett expressziót (upregulációt) mutató gének (A) esetén láthatjuk, hogy a vad típusú embriókban a vizsgáltnál korábbi embrionális stádiumban mutatnak magasabb expressziós szintet, míg a deléciós mutánsban csökkent expressziót mutató (downregulálódott) gének (B) korábbi embrionális stádium során expresszálódnak alacsonyabb szinten. Ez alapján a Hat1 $^{457}$ embriók a valós koruknál fiatalabbnak tűnnek, ami egy fejlődésbeli csúszással magyarázható.

A génexpressziós változások 83\%-a az embrionális transzkripciós program késésére vezethető vissza. Azonban sikerült azonosítanunk 370 gént, melyek expressziós változása nem magyarázható ezzel a fejlődésbeli csúszással. Ezen gének molekuláris funkciójukat tekintve jelentős részben nukleinsav kötésben, illetve transzkripciós faktor aktivitásban játszanak szerepet (19. ábra). 


\begin{tabular}{|l|l|l|l|l|}
\hline \hline$>10^{-3}$ & $10^{-3}-10^{-5}$ & $10^{-5}-10^{-7}$ & $10^{-7}-10^{-9}$ & $<10^{-9}$ \\
\hline \hline
\end{tabular}

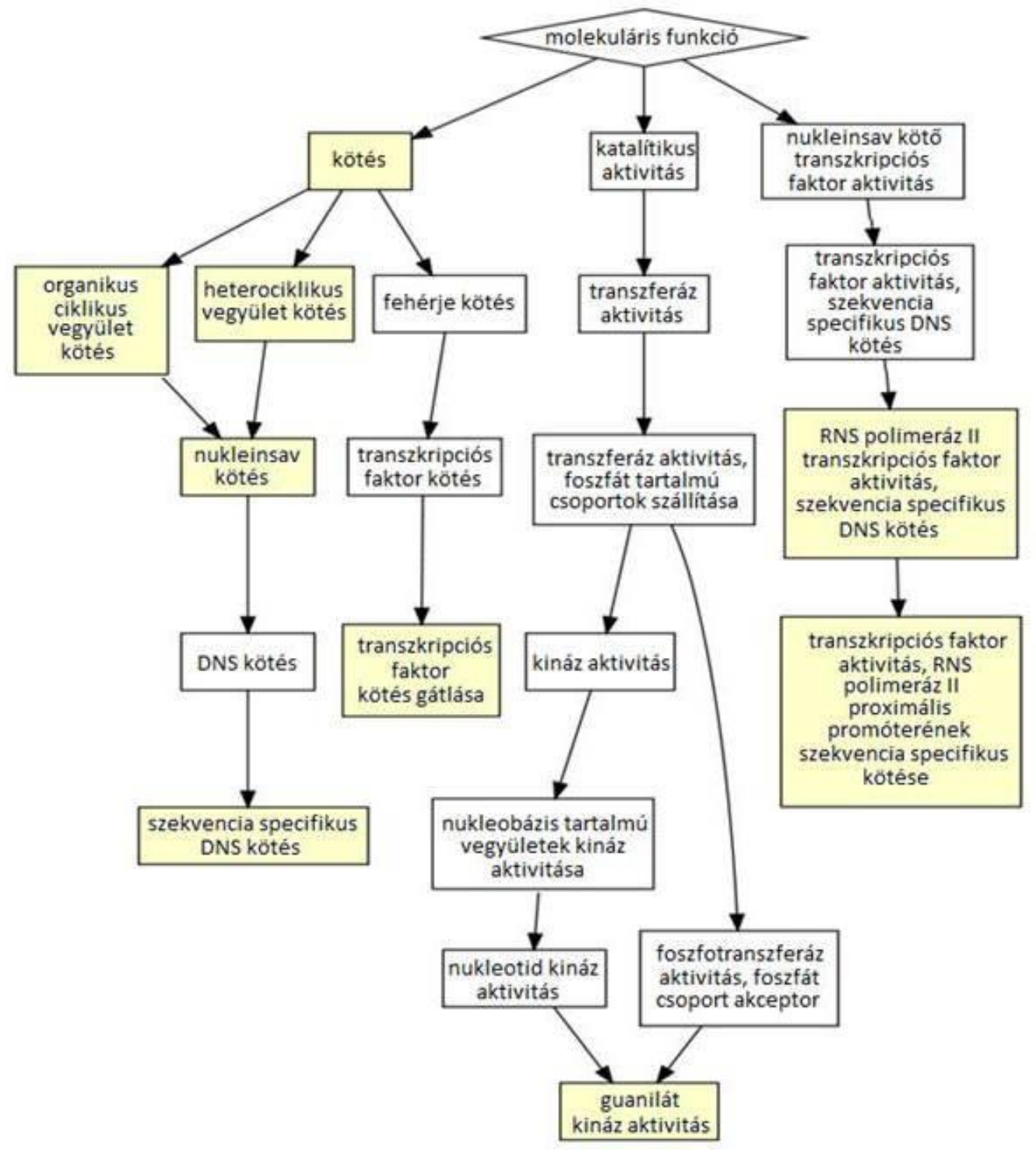

19. ábra. A fejlődésbeli késéssel nem magyarázható gének molekuláris funkciójának GO analízise. A P-érték minden esetben $10^{-5}$ alatti érték. A funkciók között leginkább a tarnszkripciós faktor aktivitás és nukleinsav kötés figyelhető meg.

Az 1397 emlekedett expressziót mutató (upregulált) gén közül 154, a 740 csökkent expressziót mutató (downregulált) gén közül 216 expressziós változása nem magyarázható a fejlődésbeli csúszással. Biológiai folyamatokban való részvételük szerint a Hat1 deléció hatására megemelkedett expressziójú gének főként fejlődési és transzlációs szabályozók, a csökkent expressziót mutató gének pedig alap metabolizmusban részt vevő faktorok (20. ábra). 
A Hat1 ${ }^{\Delta 57}$ upregulált gének

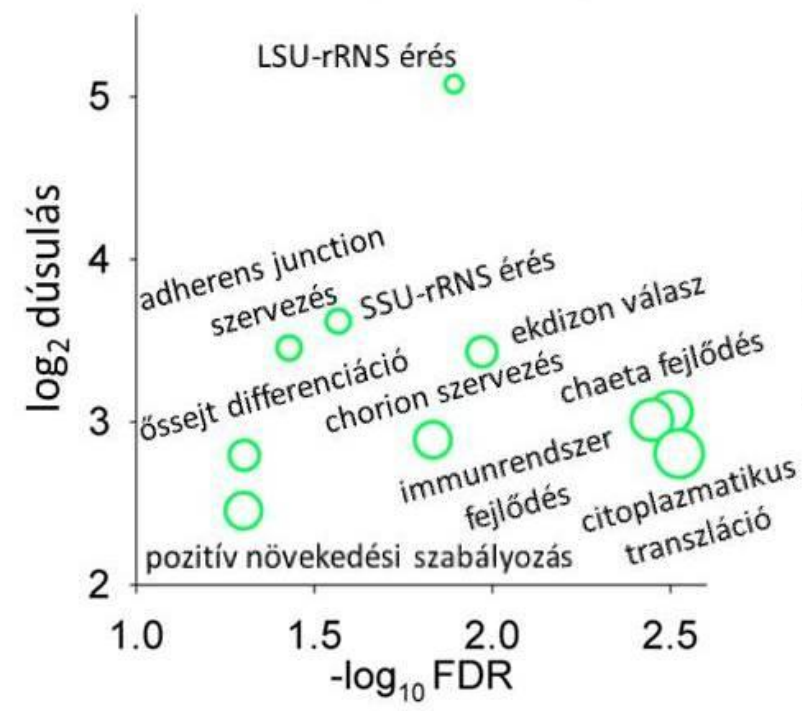

B

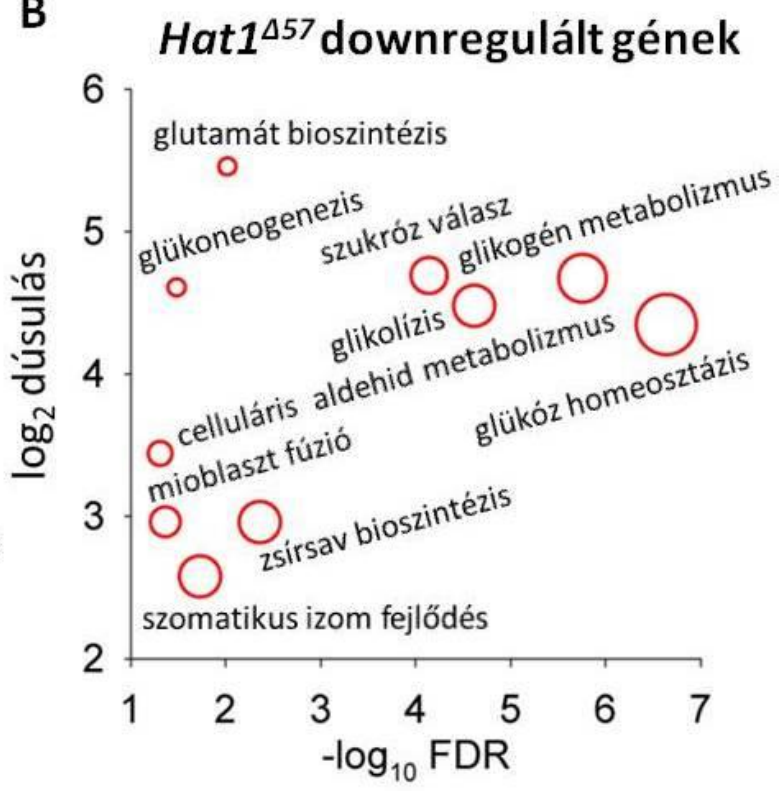

20. ábra. A fejlődésbeli késéssel nem magyarázható gének biológiai folyamatokban betöltött szerepe. A fejlődési csúszással nem magyarázható gének csoportosítása biológiai folyamatokban való részvételük szerint külön a Hatl deléciós mutáns embriókban emelkedett expressziót mutató (upregulált - A) és a csökkent expressziót mutató (downregulált - B) kategóriákra nézve. Az Y tengelyen a dúsulás mértéke, az $\mathrm{X}$ tengelyen pedig a szignifikancia értéke látható az egyes kategóriáknak. A vad típusú embriókhoz képest megemelkedett expressziójú gének között többnyire transzlációs szabályozók, míg a csökkent expressziót mutató gének között elsősorban metabolizmusban részt vevő faktorok találhatóak.

\section{IV.1.10. A Hat1 deléció nem befolyásolja a höstressz érzékenységet}

Következő kísérleteinkben azt vizsgáltuk, hogy a Hatl hiánya hatással van-e stressz körülményekre való érzékenységre. Először környezeti stresszorként hőstresszt alkalmaztunk. A kísérletet $37{ }^{\circ} \mathrm{C}$-os és $40{ }^{\circ} \mathrm{C}$-os hőmérséklet alkalmazásával végeztük el. 25 - 35 perces $40{ }^{\circ} \mathrm{C}$-os kezelés, illetve $1-7$ órás $37^{\circ} \mathrm{C}$-os kezelés hatását vizsgáltuk 7 napos Hat $1^{457}$ és

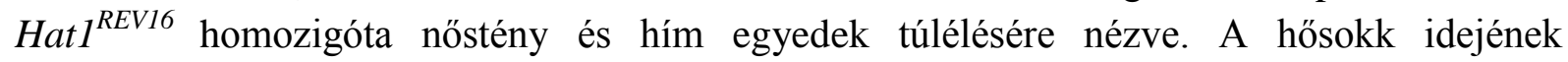
növelésével arányosan a túlélők száma fokozatosan csökkent mindkét genotípus esetén, azonban a Hat ${ }^{457}$ egyedek túlélési százaléka egyik vizsgált esetben sem tért el szignifikánsan a revertáns kontrollétól. A hőstressz kísérletünkben a hímek bizonyultak érzékenyebbnek, így rajtuk mutatjuk be a túlélési arányokat a deléciós mutáns és a precíz revertáns kategóriák esetén (21. ábra). 
A

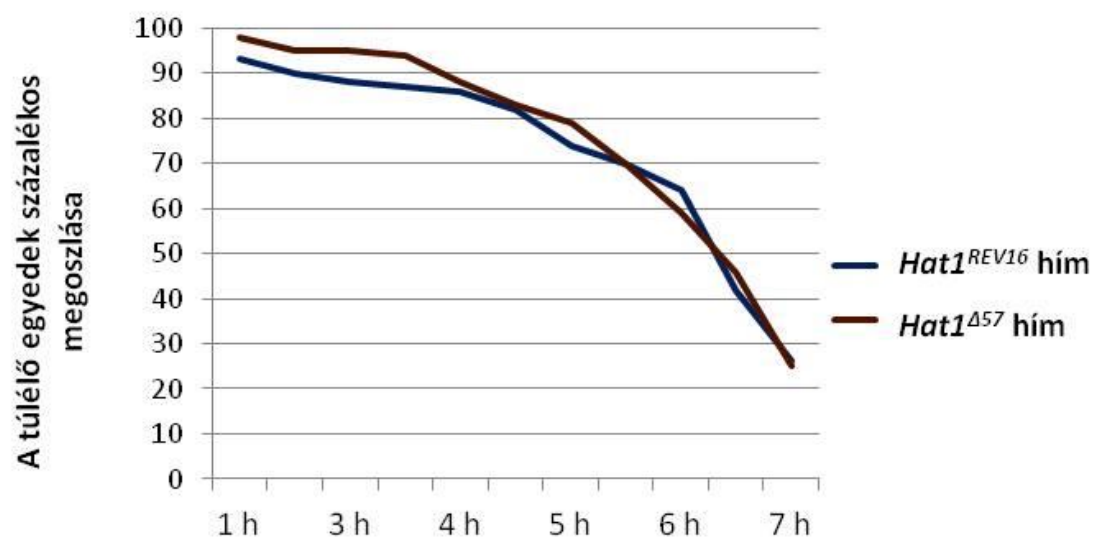

B

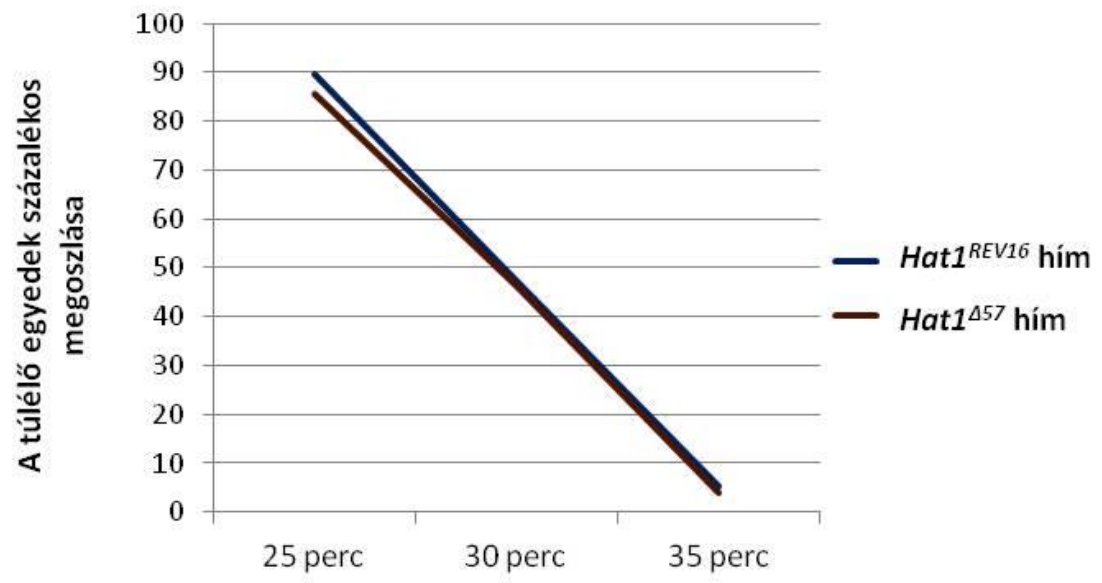

21. ábra. A Hat1 deléció nem befolyásolja az egyedek hőstressz türését. Túlélési görbék $37{ }^{\circ} \mathrm{C}-\mathrm{os}$ (A) és $40{ }^{\circ} \mathrm{C}$-os (B) hőstressz alkalmazása után homozigóta Hat $1^{457}$ és Hat ${ }^{\text {REV16 }}$ hím egyedeken. A $37{ }^{\circ} \mathrm{C}$-os hőstressz 7 órán keresztül, míg a $40^{\circ} \mathrm{C}$-os 35 percig zajlott. Mindkét körülmény hasonló lefutású túlélési görbét eredményezett a Hat $^{457}$ és Hat ${ }^{\text {REV16 }}$ kategóriák esetén, vagyis erre a stressz kondícióra nincs hatása a Hatl deléciónak.

\section{IV.1.11. Csökkent Hat1 dózis hatásának vizsgálata Huntington-kór modellben}

A másik stressz körülmény, amit vizsgálni kívántunk, a protheopátiás stressz. A Huntington-kór megjelenését okozó mutáns Huntingtin fehérje intracelluláris aggregátumokat képez és abnormális interakciókat is létrehoz más fehérjékkel, akadályozva ezzel egyes esszenciális celluláris folyamatok fiziológiás müködését. Az egyik olyan fehérje típus, mellyel aggregátum formában kapcsolatba lép, a hiszton acetiltranszferáz enzimek. ${ }^{252} 242293$ A hiszton acetiltranszferázok nem megfelelő müködése az acetiláltság zavarához és transzkripcionális diszregulációhoz vezet, melyek jellemzőek is a Huntington-kóros páciensekre. $^{259}$

Kíváncsiak voltunk, hogy a Hat1 citoplazmatikus hiszton acetiltranszferáz hatással lehet-e a Huntington-kór patomechanizmusára. Ennek vizsgálatára olyan transzgenikus Drosophila melanogaster törzset használtunk, amely hordozza a humán Huntingtin gén 1-es exonját egy 
120 glutaminból álló patológiás hosszúságú poliglutamin szakaszt kódoló CAG ismétlődéssel (UAS-HttexlQ120 vagy $m H t t)$. Ennek a transzgénnek az expresszióját a neuronális elav-GAL4 driverrel indukáltuk.

A kísérlet során olyan keresztezéseket állítottunk össze, melyekben a hímek nem expresszálják a $m H t t$ transzgént, tehát egészségesnek tekinthetők. A nőstények expresszálják a $m H t t$-t, és a nőstények egyik fele a Hatl vad allélját hordozza, a másik felében pedig a Hat ${ }^{457}$ mutáció heterozigóta formában jelen van. További kontrollként olyan keresztezést is végeztünk, amelyben a $H_{a t 1}{ }^{R E V 16}$ precíz revertánst használtuk. Az utódkategóriák a következők voltak: elav-GAL4/w; UAS-HttQ120/+, TM6 Sb/+ (expresszálja a mutáns Htt transzgént, „beteg” kontroll), elav-GAL4/w; UAS-HttQ120/+; Hat1 ${ }^{457}$ vagy Hat1 REV16/+ $^{\text {. }}$ (amelyben expresszálódik a mutáns $H t t$ és mellette Hatl deléciós vagy revertáns allélt hordoz), w/Y; UAS-HttQ120/+; TM6 Sb/+ (nincs mHtt expresszió és nem hordoz Hat1 deléciós vagy revertáns allélt), w/Y; UAS-HttQ120/+; Hat ${ }^{457}$ vagy Hat $1^{\text {REV16 } /+}$ (nincs $m H t t$ expresszió, de Hat1 deléciós vagy revertáns allélt hordoz).

\section{IV.1.11.a. A Hat1 részleges hiányának hatása a mHtt expresszáló állatok életképességére}

Elsőként az imént felsorolt egyedek életképességét teszteltük az adultok kikelési arányának vizsgálatával. A kísérleti eredményekből jól látszik, hogy bár a Hatl mutáció jelenlétében a mHtt-t expresszáló egyedek kikelési aránya a duplájára nőtt, a Hat1 precíz revertánssal végzett keresztezések utódainál ugyanez az eredmény látható (22. ábra). Az eredmény mindkét esetben szignifikáns változás volt, Hat $1^{457}$ esetén t-próba: $2,23165 \times 10^{-6}$, Hat $^{\text {REVI6 }}$ esetén t-próba: $9,9927 \times 10^{-6}$. Így elképzelhető, hogy valamilyen háttér mutáció okozza a fenotípusbeli javulást. 
A

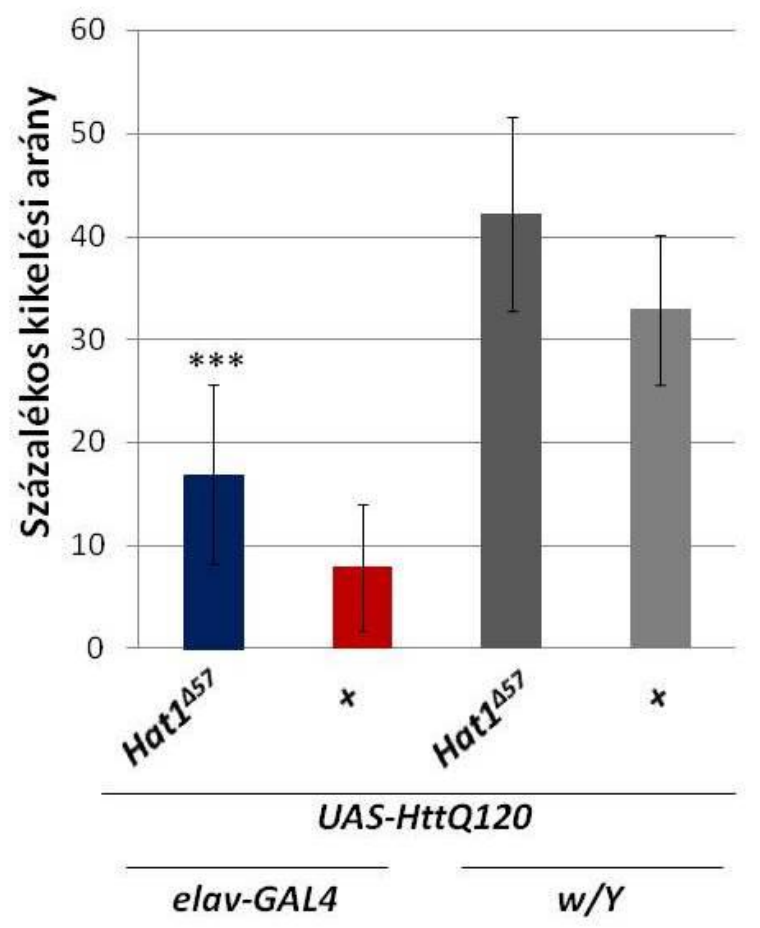

B

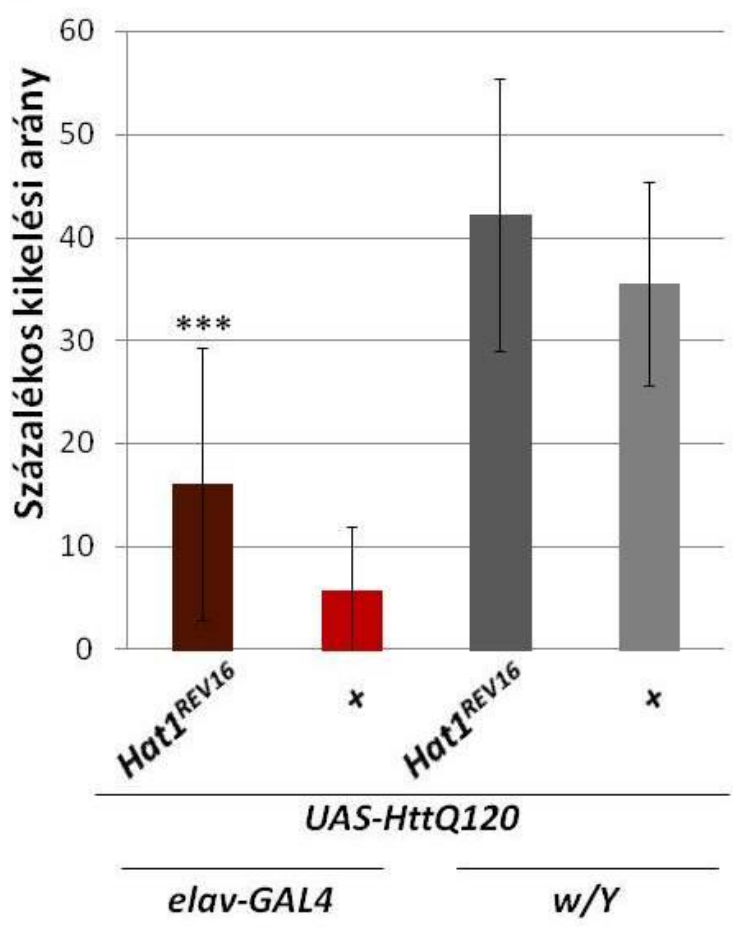

22. ábra. A Hat1 ${ }^{457}$ és Hat1 ${ }^{\text {REV16 }}$ allél azonos hatást fejt ki az életképességre Drosophila Huntington-kór modellben. (A) A Hatl deléció hatása az mHtt-t expresszáló muslicák kikelésére. (B) Azonos kísérlet a Hat ${ }^{\text {REV16 }}$ precíz revertánssal végrehajtva kontrollként. A kísérletben találhatóak mHtt-t expresszáló és nem expresszáló, Hat ${ }^{457}$ vagy Hat1 ${ }^{\text {REV16 }}$ allélt hordozó és nem hordozó kategóriák egyaránt. A diagramokon hibasávként szórás látható feltüntetve. A statisztikai értékelés Student tpróbával történt, ahol a ***: P-érték $<10^{-5}$. A Hat ${ }^{457}$ deléciót hordozó $\mathrm{mHtt}-\mathrm{t}$ expresszáló egyedek közül szignifikánsan több kelt ki a „beteg” mHtt-t expresszáló kontoroll kategóriához képest, azonban ugyanez az eredmény látható a Hat1 ${ }^{\text {REVI6 }}$ revertáns allélt hordozó egyedek esetén is.

\section{IV.1.11.b. A Hat1 részleges hiányának hatása mHtt expresszáló állatok élettartamára}

A Huntington-kórra és a Huntington-kór Drosophila modelljére egyaránt jellemző a rövidebb élettartam. Ezért vizsgáltuk az életképesség teszt során alkalmazott egyedek élethosszát is. A mHtt-t expresszáló, Hat1 ${ }^{457} /+$ illetve Hat ${ }^{\text {REV } 16} /+$ heterozigóta egyedek élettartam görbéje hasonló lefutású, azonban a Hat1 ${ }^{457}$ allélt hordozó egyedek 25\%-os $(\mathrm{P}=0,0067)$ és $50 \%$-os $(\mathrm{P}=0,0117)$ mortalitási értékei szignifikánsan jobbak a csak mHtt-t expresszáló kategóriánál, míg a Hat ${ }^{R E V 16}$ allélt hordozók esetén ez a javulás nem figyelhető meg (23. ábra, 2. táblázat). 


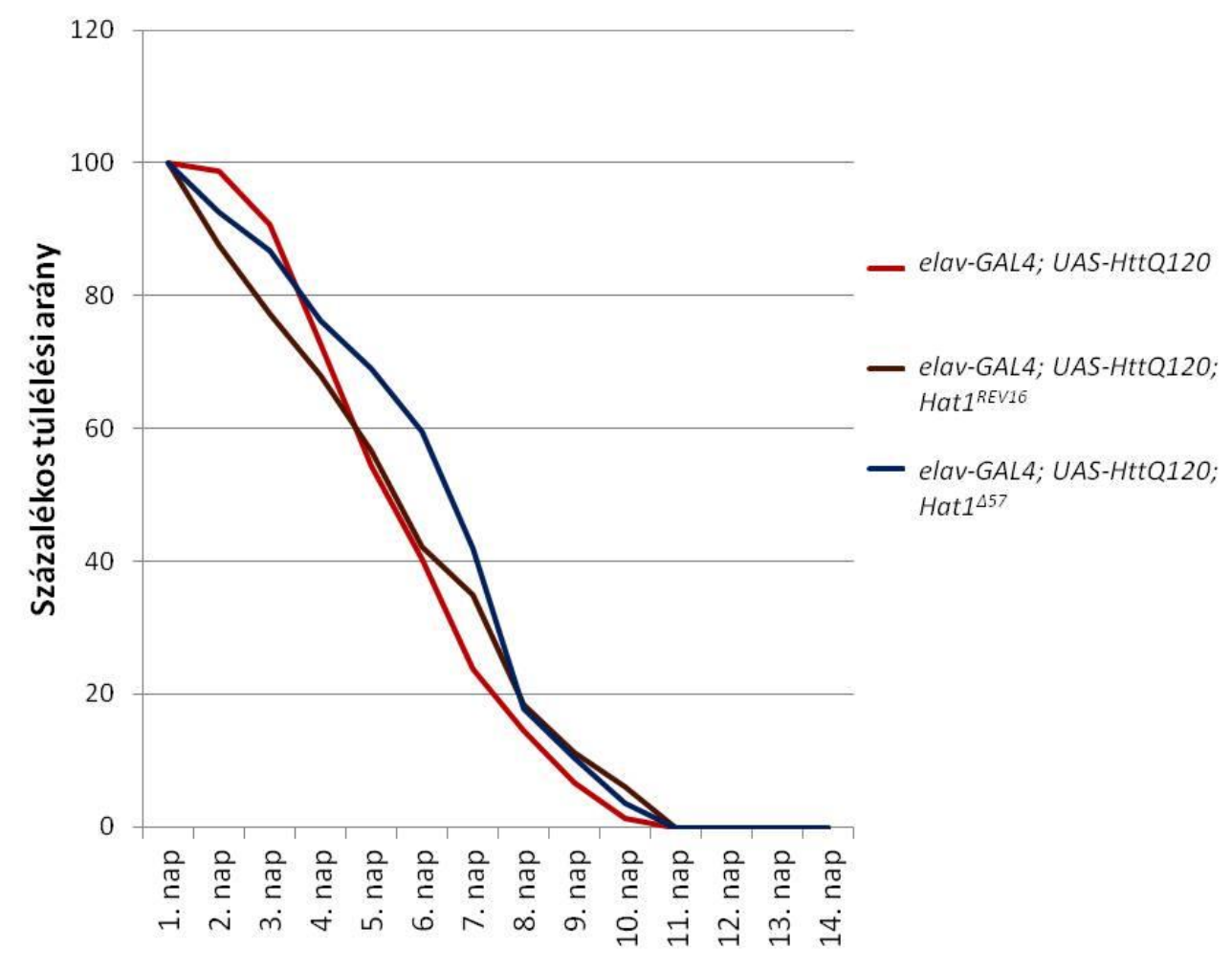

23. ábra. A Hat1 deléció kismértékü javulást fejt ki az élettartamra Huntington-kór modellben. A Hat1 ${ }^{457}$ és Hatl ${ }^{\text {REVl6 }}$ heterozigóta allél hatása a $\mathrm{mHtt}-\mathrm{t}$ expresszáló muslicák élethosszára. A deléciót hordozó egyedek 25\%-os és 50\%-os mortalitási értéke szignifikánsan jobbnak bizonyult a mHtt-t expresszáló „,beteg” kontrollhoz képest.

\begin{tabular}{|c|c|c|c|c|}
\hline Összehasonlított genotípusok & $\begin{array}{c}\text { P-érték 25\%-os } \\
\text { mortalitásnál }\end{array}$ & $\begin{array}{c}\text { P-érték 50\%-os } \\
\text { mortalitásnál }\end{array}$ & $\begin{array}{l}\text { P-érték 75\%-os } \\
\text { mortalitásnál }\end{array}$ & $\begin{array}{c}\text { P-érték 90\%-os } \\
\text { mortalitásnál }\end{array}$ \\
\hline elav-GAL4/w;HttQ120/+;Sb/+ v.s. elav-GAL4/w;HttQ120/+;Hat1 ${ }^{R E V 16} /+$ & 0,6479 & 0,4654 & 0,4077 & 0,2588 \\
\hline elav-GAL4/w;HttQ120/+;Sb/+ v.s. elav-GAL4/w;HttQ120/+;Hat $1^{\Delta 57 /+}$ & 0,0067 & 0,0117 & 0,449 & 0,307 \\
\hline elav-GAL4/w;HttQ120/+;Hat1 ${ }^{R E V 16} /+$ v.s. elav-GAL4/w;HttQ120/+;Hat $1^{\Delta 57 /+}$ & 0,102 & 0,4109 & 0,8437 & 0,3392 \\
\hline
\end{tabular}

2. táblázat. A mHtt-t expresszáló, Hat1 ${ }^{457}$ és Hat1 ${ }^{\text {REV16 }}$ allélt hordozó egyedek meghatározott mortalitási arányaihoz tartozó szignifikancia értékek. A mHtt-t expresszáló „beteg” kontroll egyedekkel való összehasonlításból származó adatok. A szignifikáns eltérések piros színnel kiemelve láthatóak. A különbségek közötti szignifikancia értékelése Mann-Whitney U Teszttel történt.

IV.1.11.c. A Hat1 részleges hiánya enyhiti a mHtt expresszáló állatokban megfigyelhetö neurodegenerációt

Megvizsgáltuk az imént bemutatott genotípusú állatok neuronpusztulásának mértékét is. Muslicákban a neuronpusztulás jól detektálható az összetett szemük átvilágításával. Ommatídiumonként 8 rhabdomer található, melyekből 7 látható (1 takarásban van). 
Neurodegeneráció hatására a rhabdomerek száma csökken és ezt a különbséget vizsgáltuk kísérletünkben úgynevezett pseudopupil assay alkalmazásával.

Annak ellenére, hogy a Hat ${ }^{\Delta 57}$ és Hat ${ }^{R E V 16}$ allél hatása a mHtt-t expresszáló muslicák életképességére azonos volt és az élettartamon is csak kis mértékben javított a deléciós allél, a neurodegenerációs vizsgálat során sokkal kisebb mértékủ retinális neuronpusztulást mutatott a Hat1 deléciós allélt hordozó és mHtt-t expresszáló kategória a mHtt-t expresszáló „,beteg” belső kontrolljához és a revertáns allélt hordozó kontroll egyedekhez képest is. A különbség a deléciós és revertáns kategória között szignifikáns, t-próba: $\mathrm{P}=7,88 \times 10^{-14}$ (24. ábra).

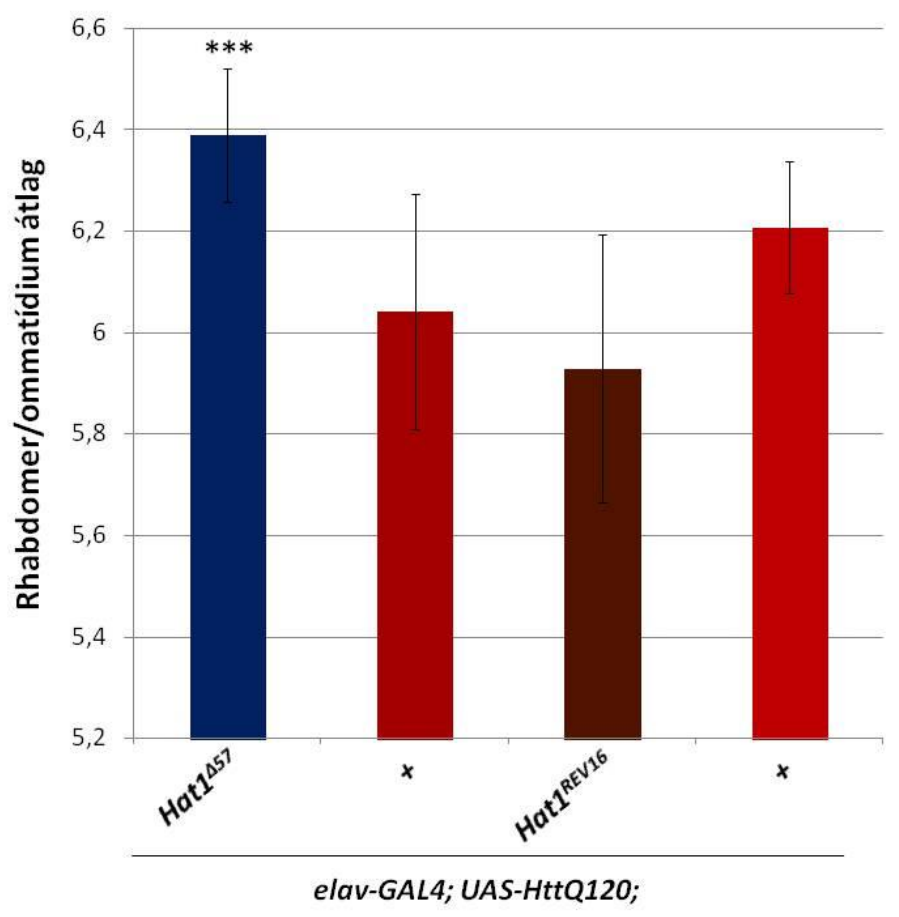

24. ábra. A Hat1 részleges hiánya csökkenti a neurodegeneráció mértékét Huntington-kór modellben. Hat1 ${ }^{457}$ vagy Hat $1^{\text {REV16 }}$ allélt hordozó, mHtt-t expresszáló egyedek és saját belső mHtt-t expresszáló „,beteg” kontrolljuk neurodegenerációjának vizsgálata. Eredményként az ommatídiumonkénti rhabdomer szám átlaga látható ábrázolva. A diagramokon hibasávként a szórás látható feltüntetve. A statisztikai értékelés Student t-próbával történt, ahol a ${ }^{* * *}: \mathrm{P}<10^{-13}$. A Hatl deléciót hordozó egyedek neuronpusztulása szignifikánsan kisebb mértékü a kontroll kategóriákénál.

Tehát összességében elmondható, hogy a Drosophila Hat1 részleges hiánya csökkenti a Huntington-kór kiváltotta neurodegeneráció mértékét. 


\section{IV.2. His4r hiszton fehérjék acetilációs módosításainak hatása a Huntington-kór patomechanizmusára}

Annak vizsgálatára, hogy a hiszton deacetilázok gátlása estén, illetve saját kísérleteinkben a Hat1 hiánya esetén, a mHtt fehérje kiváltotta tünetek enyhülésében mely hiszton pozícióra gyakorolt hatás játszat szerepet, a His4r hiszton fehérje egyes acetilálható pozícióinak jelentőségét vizsgáltuk. A His4r fehérje a H4-es hisztonnal fehérje szekvenciájában megegyezik, azonban kifejeződésük eltérő. ${ }^{30}$ Feltételezhető, hogy a His4r a H4-et a transzkripcionálisan aktív helyeken lecseréli, hasonlóan, mint ahogy az a H3 és a H3.3 variánsok esetén megfigyelhető ${ }^{294}$. A H4 és His4r hiszton N-terminális részén acetilálható aminosavak az 5-ös, 8-as, 12-es és 16-os pozíciójú lizinek. Ezek vizsgálatára olyan szubsztitúciókat hordozó transzgenikus konstrukciókat hoztunk létre, amelyekről az átíródó His4r hiszton fehérjék ezekben a pozíciókban (K5, K8, K12, K16) acetiláltságot, vagy acetilálatlan állapotot mimikálnak.

\section{IV.2.1. His4r pontmutáns konstrukciók és transzgenikus Drosophila vonalak elöállitása}

Létrehoztunk egy pENTR3C-His4r-GB vektrokonstrukciót, mely tartalmazza a vad típusú $H i s 4 r$ gént a start kodontól a transzlációs stop elötti kodonig, annak intronjaival együtt (GB: gene body). Ebben terveztünk létrehozni acetilált lizint (lizin > glutamin csere, K>Q) illetve módosítatlan lizint (lizin > arginin csere, $\mathrm{K}>\mathrm{R}$ ) mimikáló pontmutációkat az 5-ös, 8-as, 12-es és 16-os lizinek kodonjaiban (K5R, K5Q, K8R, K8Q, K12R, K12Q, K16R, K16Q). Ehhez megfelelő módosításokat tartalmazó primereket terveztünk (lásd az Anyagok és módszerek fejezetben), majd ezeket a primereket alkalmazva inverz PCR-on alapuló NEB Q5 irányított mutagenezis módszerrel pontmutáns konstrukciókat hoztunk létre. A szubsztitúciót hordozó szekvenciákat pTWF-attB vektorba klónoztuk, ami egy a transzgén GAL4 függő aktivációját és C-terminális FLAG-tag jelölést lehetővé tevő, $\varphi \mathrm{C} 31$ integráz mediálta helyspecifikus transzgén inszercióra alkalmas vektor. A konstrukciókat attP-zh86Fb transzgén dokkoló helyet hordozó embriókba injektáltattuk. A kikelt állatokat egyedi keresztezésekbe vittük $w^{1118}$ törzzsel, majd a transzgenikus (mini-white szemszín markert hordozó) utódok közül kiválasztottunk négy-négy vonalat minden pozícióra nézve, melyekből homozigóta törzseket állítottunk elö.

A létrehozott transzgenikus törzsek validálásához a törzsekből izolált Drosophila genomi DNS templáton a pTWF-attB vektor beépülő részére tervezett közös primerpárral végeztünk PCR reakciókat, melyek termékeit kapilláris szekvenálással ellenőriztük. Megállapítottuk, hogy a vizsgált transzformáns vonalak hordozzák az általunk tervezett szubsztitúciókat.

\section{IV.2.2. A His4r transzgének kifejezödésének vizsgálata}




\section{IV.2.2.a. A transzgének transzkripciós szintjének vizsgálata}

A különböző pontmutációkat hordozó His4r transzgéneket azonos genomi pozícióba, ugyanarra a dokkoló helyre integráltuk azért, hogy kifejeződésük ne függjön a genomi környezettől. Hogy meggyőződjünk a transzgének azonos kifejeződéséről, a szövetspecifikus neuronálisan kifejeződő elav-GAL4 driverrel indukált expressziójú UAS-His4r transzgének transzkripciós szintjét RT-qPCR analízissel vizsgáltuk. Ehhez a vizsgálni kívánt egyedek fejeiből készítettünk cDNS mintát és az UAS-His4r génre (His4r-qF), valamint a pTWF-attB vektor beépülő részére specifikus (pTWF-attB-qR) expressziós primereket használtunk. Méréseink alapján RNS expressziós szintben nincs számottevő különbség a különböző módosításokat hordozó transzgének között. (25. ábra).

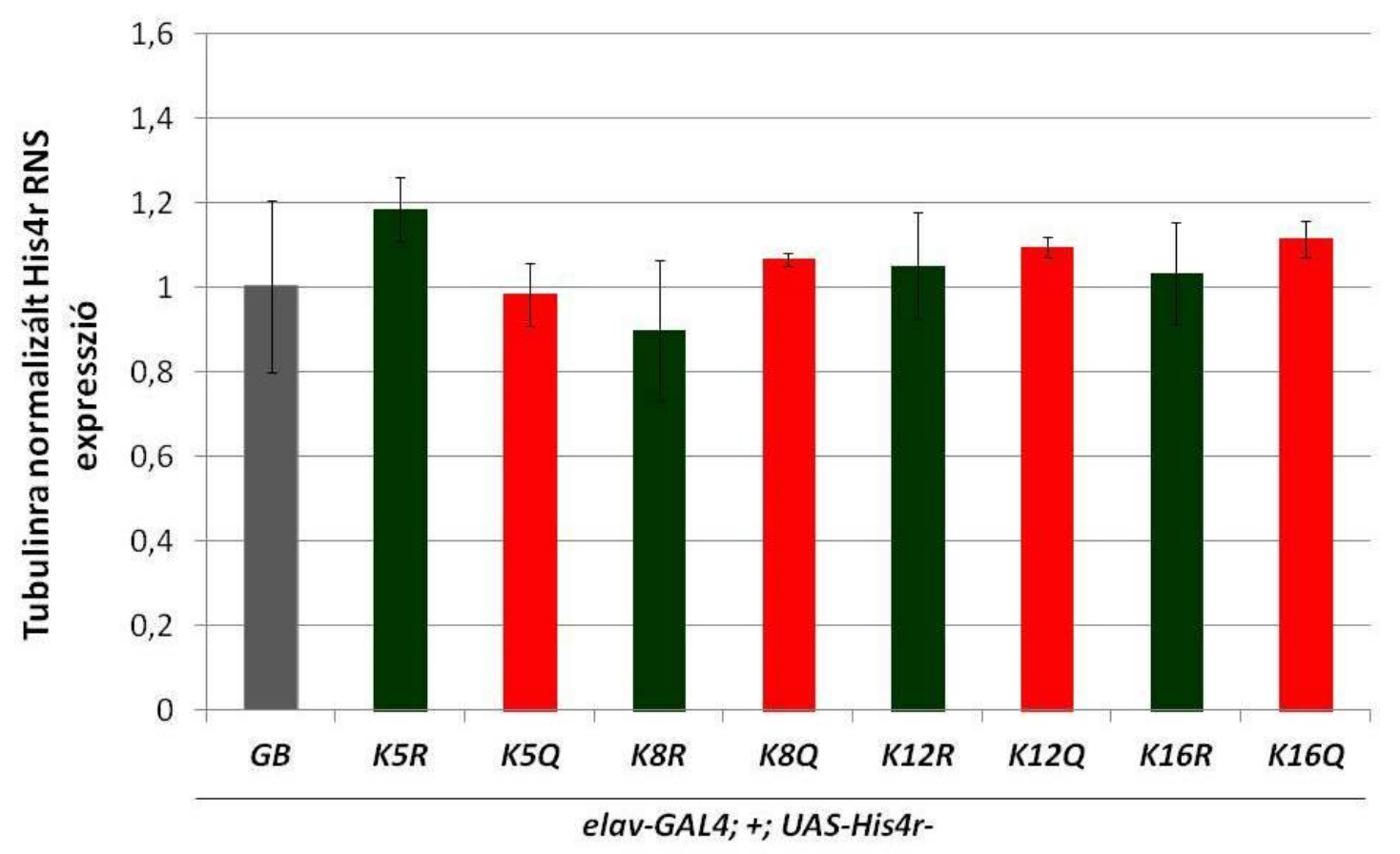

25. ábra. A transzgenikus His4r RNS expresszió nem mutat szignifikáns eltéréseket. elav-GAL4 neuronális driverrel indukált expressziójú transzgenikus UAS-His $4 r$ szubsztitúciókat hordozó (K5R, K5Q, K8R, K8Q, K12R, K12Q, K16R, K16Q) és vad típusú $U A S$-His4r transzgént expresszáló (GB) törzseken végzett His4r transzgén RNS expresszió mérés qPCR-ral tubulin háztartási génre normalizálva. Az egyedek a transzgénre és a driverre nézve heterozigóták voltak. A diagramokon hibasávként szórás látható feltüntetve. Az egyes transzgének módosítástól függetlenül egyenletes expressziót mutatnak.

\section{IV.2.2.b. A His4r transzgének fehérje expressziós szintjének vizsgálata}

Vizsgáltuk a különböző His4r transzgéneket expresszáló muslicákban a transzgénről származó His4r fehérje szintjét is. A transzformáns vonalakat neuronális elav-GAL4 driver törzshöz kereszteztük a pontmutációt hordozó $U A S$-His $4 r$ gének expresszáltatásához, majd az 
utódokon anti-FLAG specifikus ellenanyagot használva western blot kísérletet végeztünk a FLAG-taggel jelölt UAS-His4r változatok fehérje szintjének ellenőrzésére. Bemérési kontrollként $\mathrm{H} 3$ elleni ellenanyagot alkalmaztunk. A szekvenálással ellenőrzött vonalak mindegyike expresszálja a transzgént, azokról fehérje képződik. A His4r fehérje szintje azonban nem azonos mennyiségü az egyes vonalakban. Az eredmények azt mutatják, hogy a Q (acetilációt mimikáló glutamin) módosítás minden pozíció esetén alacsonyabb fehérje expressziót eredményezett az R (módosítatlan lizint mimikáló arginin) módosításnál, különösen alacsony His4r fehérje szintet mutattunk ki a His4r-K5Q és a His4r-K16Q pontmutációt hordozó fehérjét expresszáló állatokban (26. ábra). Szignifikáns a különbség a GB expresszióhoz képest a K5Q $(\mathrm{P}=0,0119)$, a K12R ( $\mathrm{P}=0,0035)$, a K16R $(\mathrm{P}=0,0308)$ és a K16Q $(\mathrm{P}=0,000401)$ módosítások esetén. Mivel a transzgének transzkripcionális aktivitásában nem találtunk számottevő különbséget, így feltételezhető, hogy valamilyen fehérje expresszió vagy lebontásbeli különbség okozza az acetilált lizint mimikáló módosítások esetén a csökkent fehérje szintet.

A

elav-GAL4; +; UAS-His4r-

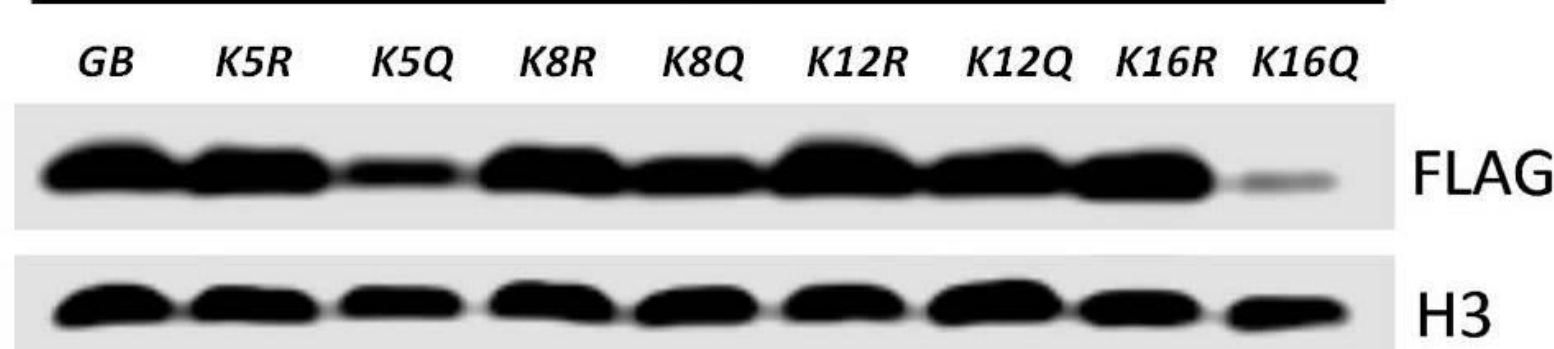

B

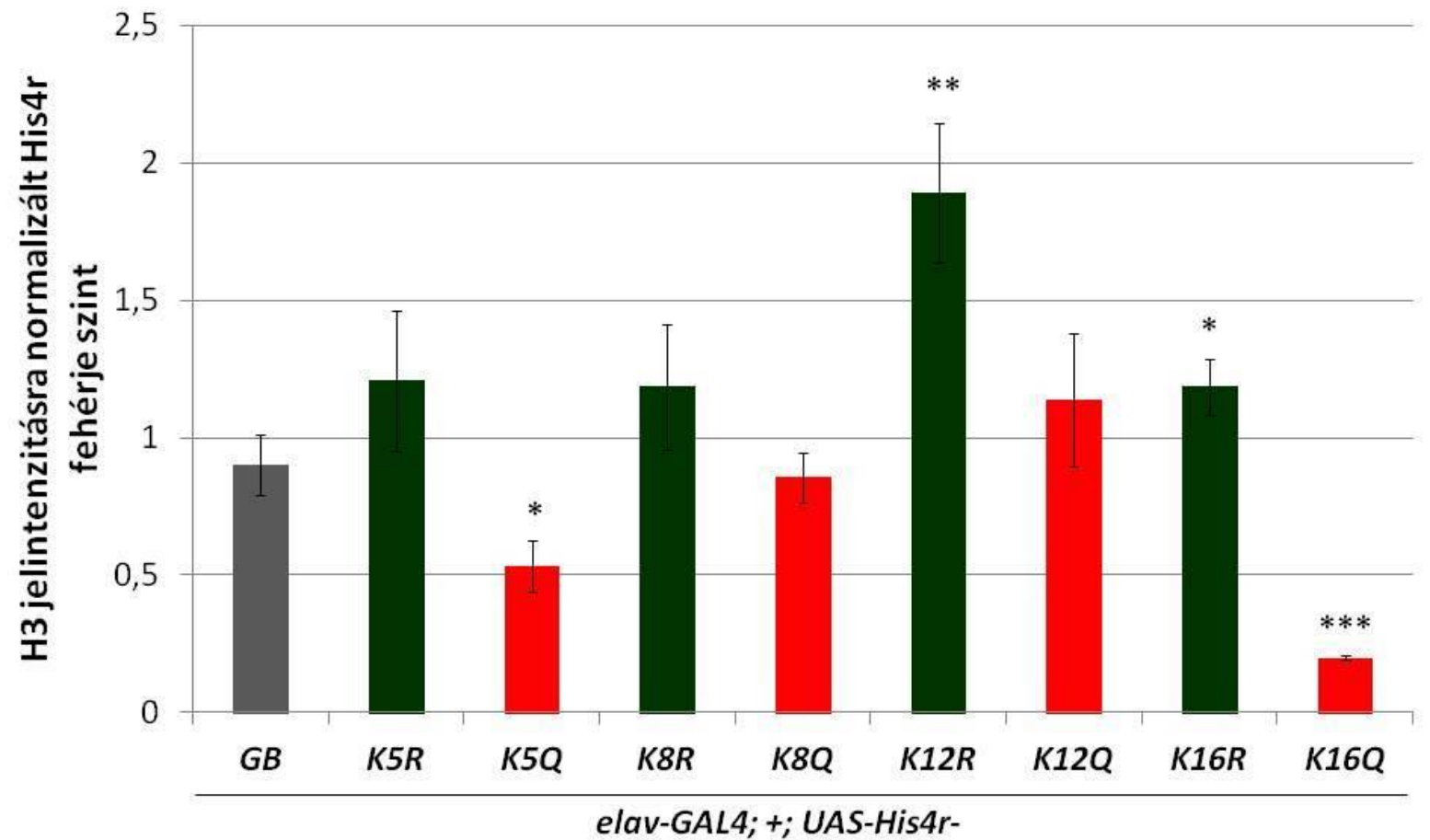


26. ábra. A His4r transzgénekről termelődő fehérje szintje eltéréseket mutat a szubsztitúciók hatására. (A) Reprezentatív western blot kép az elav-GAL4 neuronális driverrel indukált expressziójú transzgenikus $U A S$-His4r szubsztitúciókat hordozó (K5R, K5Q, K8R, K8Q, K12R, K12Q, K16R, K16Q) és vad típusú UAS-His4r transzgént expresszáló (GB) törzseken. Az egyedek a transzgénre és a driverre nézve heterozigóták voltak. Fehérje szinten az egyes módosítások eltéréseket mutatnak, különösen a K16Q és K5Q esetén, ahol a kontrollnál (GB) lényegesen alacsonyabb a fehérje szint. (B) A western blot kísérletek jelintenzitás értékeinek kvantifikálása, normalizálva a H3 loading kontroll értékekre (genotípusonként három biológiai és két technikai replikátum). A diagramokon hibasávként szórás látható feltüntetve. A statisztikai értékelés Student $\mathrm{t}$ próbával történt, ahol az egyes módosítások a GB jelintenzitás értékeihez lettek hasonlítva és a *: $\mathrm{P}<0,05, * *: \mathrm{P}<0,01, * * *$ : $\mathrm{P}<0,001$ értéket jelöl. Az $\mathrm{R}$ változatok magasabb, míg a $Q$ változatok alacsonyabb fehérje szintet mutatnak.

\section{IV.2.2.c. A transzgenikus His4r fehérjék sejten belüli lokalizációjának vizsgálata}

Azt feltételeztük, hogy a FLAG-tag nem fogja zavarni a fehérje foldingot és transzportot, és az UAS-His $4 r$ transzgenikus fehérjék módosítástól függetlenül bejutnak a sejtmagba. Ennek ellenőrzéséhez a western blot kísérletnél is alkalmazott elav-GAL4 driver törzshöz kereszteztük a transzgenikus vonalakat és L3 stádiumú lárvák nyálmirigyein végeztünk immunfestést FLAG-tag elleni ellenanyaggal, a sejtmagokat pedig DAPI sejtmag festékkel jelöltük. A várakozásainkkal megegyező eredményt kaptunk, a transzgenikus fehérjék sejtmagi lokalizációt mutatnak, képesek bejutni a sejtmagba (27. ábra).

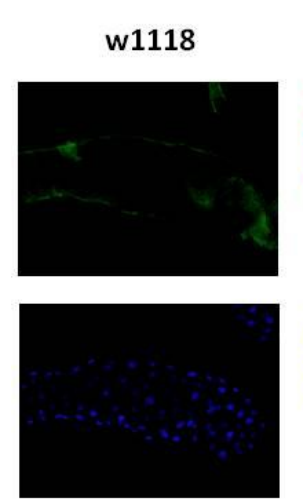

His $4 r-G B$
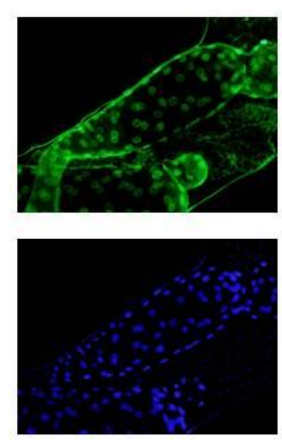

His4r-K5R
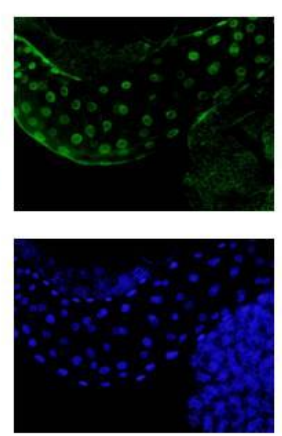

His4r-K5Q
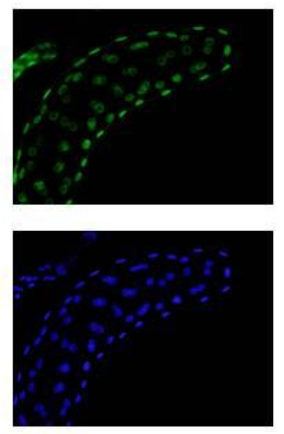

His4r-K8R
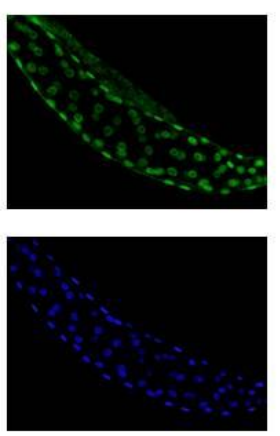

His4r-K8Q
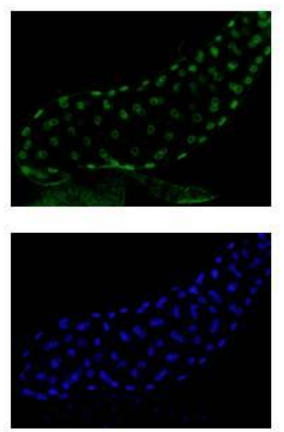

His4r-K12R
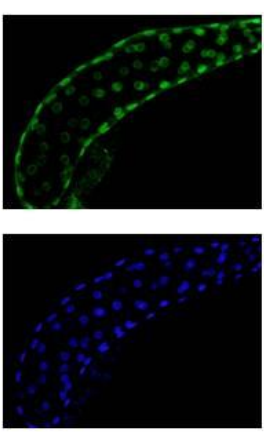

His4r-K12Q
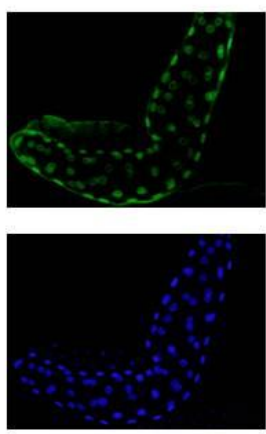

His4r-K16R

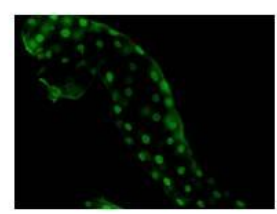

FLAG

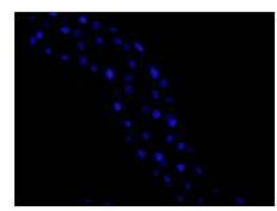

His4r-K16Q

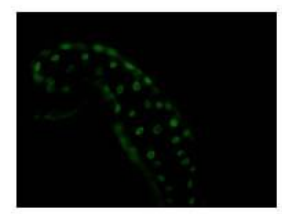

FLAG

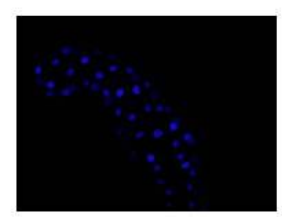

DAPI 
27. ábra. A His4r transzgének sejtmagi lokalizációt mutatnak. L3-as lárvális nyálmirigyekről készített reprezentatív fluoreszcens mikroszkópos képek az elav-GAL4 driverrel indukált expressziójú transzgenikus UAS-His4r szubsztitúciókat hordozó (K5R, K5Q, K8R, K8Q, K12R, K12Q, K16R, K16Q) és vad típusú UAS-His4r transzgént expresszáló (GB) törzseken, valamint kontrollként vad típusú, transzgént nem expresszáló $w^{1118}$ törzsön. A transzgént expresszáló egyedek a transzgénre és a driverre nézve heterozigóták voltak. A transzgenikus fehérjék lokalizációja FLAG antitest fetéssel zöld színben látható, a sejtmagok DAPI festéssel kék színnel jelennek meg. A $w^{1118}$ vad típusú, transzgenikus fehérjét nem expresszáló kontroll, így FLAG festődést nem mutat. A FLAG és DAPI festés minden transzgenikus egyedben azonos mintázatot mutat, vagyis a His4r transzgenikus fehérjék sejtmagi lokalizációja figyelhető meg.

\section{IV.2.3. A His4r pontmutánsok életképességre gyakorolt hatásának vizsgálata}

A pontmutáns UAS-His4r transzgének expresszióját elav-GAL4 driverrel indukáltuk, életképességüket $U A S$-His $4 r$ transzgént nem expresszáló, csak elav-GAL4 drivert és balanszer kromoszómát hordozó testvéreikhez hasonlítottuk a nőstények és hímek esetén egyaránt. A neuronális expressziónak egyik vizsgált esetben sem tapasztaltuk negatív hatását az életképességre nézve, a kikelési százalék minden esetben meghaladja a százat, vagyis a balanszer kromoszómát hordozó kontroll egyedek életképessége rosszabb volt az UAS-His4r transzgéneket expresszáló egyedekénél (28. ábra). 


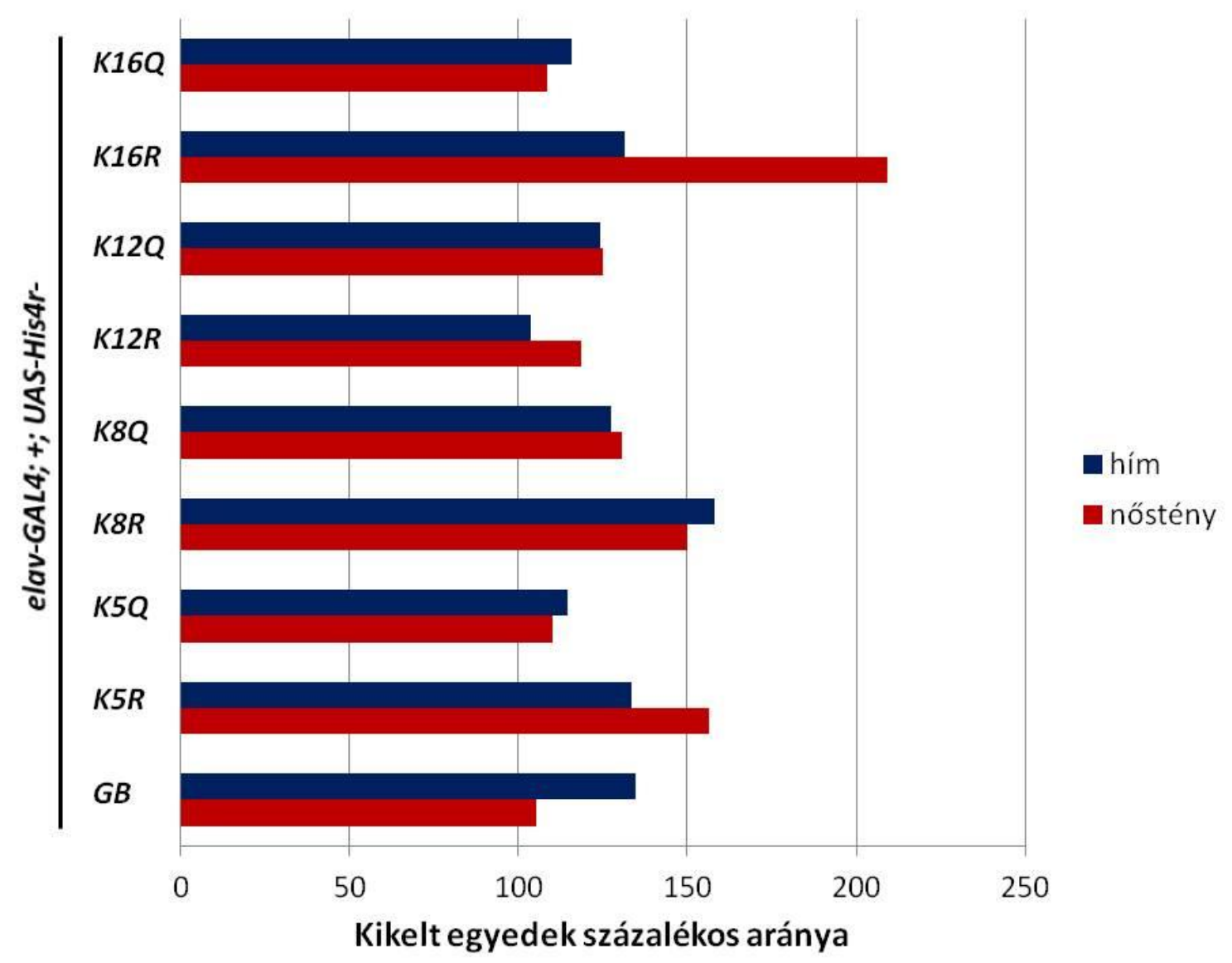

28. ábra. A His4r transzgének neuronális expressziója nincs negatív hatással az életképességre. $\mathrm{Az}$ elav-GAL4 neuronális driverrel indukált expressziójú, szubsztitúciókat hordozó (K5R, K5Q, K8R, K8Q, K12R, K12Q, K16R, K16Q) UAS$H i s 4 r$ transzgént, illetve vad típusú $U A S$-His4r transzgént expresszáló (GB) törzsek életképesség adatai. A transzgént expresszáló egyedek kikelési száma az UAS-His4r transzgént nem, csak elav-GAL4 drivert és balanszer kromoszómát (TM6 Sb) hordozó testvéreik számához lett viszonyítva, melynek arányát mutatja a diagram. A balanszer kromoszómák életképességre kifejtett negatív hatása lehet az oka a transzgént expresszáló egyedek 100\% fölötti életképesség értékeinek. Az adatok alapján azonban egyik módosításnak sincs negatív hatása az életképességre sem a hímek, sem a nőstények esetén.

\section{IV.2.4. A pontmutáns His4r transzgének expressziója nem idéz elö fotoreceptor neuron degenerációt}

A már korábban bemutatott pseudopupil assay alkalmazásával teszteltük, van-e a pontmutáns $U A S-H i s 4 r$ transzgének elav-GAL4 indukálta neuronális expressziójának hatása az érintett neuronok túlélésére. A vizsgálat 4 napos nőstény egyedeken történt. Az eredményeink azt mutatták, hogy a transzgének neuronális expressziója nem okozott fotoreceptor neuron pusztulást az egyedekben (29. ábra). 


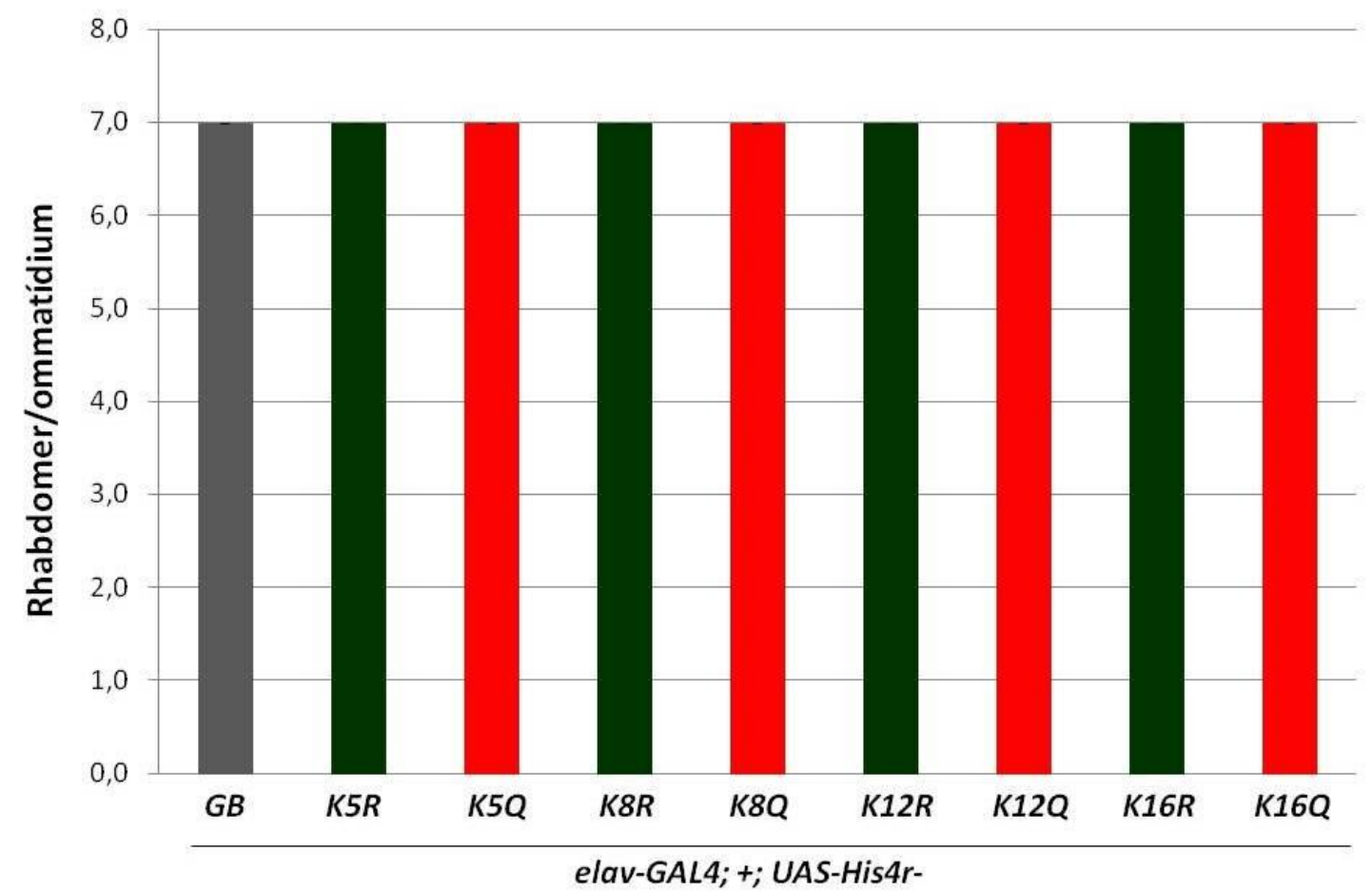

29. ábra. A His4r transzgének neuronális expressziójának nincsen hatása a fotoreceptor neuronokra. Az elav-GALA neuronális driverrel indukált expressziójú, szubsztitúciókat hordozó (K5R, K5Q, K8R, K8Q, K12R, K12Q, K16R, K16Q) UASHis4r transzgént, illetve vad típusú UAS-His4r transzgént expresszáló (GB) törzseken végzett neurodegeneráció vizsgálat. A kísérlet során a rhabdomerek ommatídiumonkénti átlagos száma került meghatározásra. Ez az érték minden vizsgált kategóriában 7-nek adódott, tehát nem volt egyik módosítás hatására sem megfigyelhető neuronális pusztulás.

A His4r expressziós kísérletek alapján összességében kijelenthető, hogy a transzgének neuronális expressziójának önmagában nincs negatív hatása, így a Huntington-kór modellben végzett kísérletek során bármilyen irányban történő változás a mutáns Huntingtin kiváltotta patológiás folyamatra specifikusnak mondható.

\section{IV.2.5. A His4r pontmutációk hatása a mutáns Htt kiváltotta patológiás folyamatokra}

Kíváncsiak voltunk, hogy a His4r különböző acetilációs állapotait mimikáló módosítások milyen hatást fejtenek ki a Huntington-kór Drosophila modelljében, illetve, hogy a változások összevethetőek-e a Hat1 deléciós teszteknél kapott eredményeinkkel.

A kísérletekhez olyan keresztezéseket állítottunk össze, melyeknek eredményeképpen négyféle utódkategória megjelenését vártuk: elav-GAL4/w; UAS-HttQ120/+, TM6 Sb/+ (amelyben a mutáns $H t t$ expresszálódik, azonban egyik His $4 r$ transzgént sem hordozza), elav- 
GAL4/w; UAS-HttQ120/+; UAS-His4r/+ (amelyben mind a mutáns $H t t$, mind valamelyik $H i s 4 r$ transzgén kifejeződik), w/Y; UAS-HttQ120/+; TM6 Sb/+ (amelyben jelen van a $m H t t$ transzgén, de driver hiányában nem expresszálódik), w/Y; UAS-HttQ120/+; UAS-His4r/+ (amelyben jelen van a $m H t t$ és a $H i s 4 r$ transzgén, de driver hiányában nem expresszálódik). Így mindkét hím kategória „egészséges” kontrolljaként szolgál a kísérleteknek, a csak $m H t t-\mathrm{t}$ expresszáló nőstény egyedek pedig az UAS-His4r transzgének valamelyikét expresszáló állatokhoz hasonlítható „beteg” kontroll egyedek.

\section{IV.2.5.a. His4r pontmutációk hatása a mutáns Htt kiváltotta csökkent életképességre}

Életképességük vizsgálatához a kikelt utódkategóriák egyedeinek számát viszonyítottuk egymáshoz. A vad típusú $U A S$-His4r gént (His4r-GB) expresszáló egyedek életképessége is nagymértékben lecsökkent a csak $m H t t$-t expresszáló „,beteg” kontrollhoz képest. Egyik UAS$H i s 4 r$ transzgént expresszáló kategória kikelt egyedszáma sem érte el a pusztán $m H t t-\mathrm{t}$ expresszáló kategóriáét, viszont a His 4 - GB-t expresszáló egyedeknél a K8Q és a K16Q módosítást hordozók életképessége jobbnak bizonyult. Ezek közül a K16Q kikelési aránya szignifikánsan nagyobb, mint a His4r-GB kontrollé (t-próba: $\mathrm{P}=0,0102$ ). A többi kategória csökkent életképességet mutatott a módosítatlan His4r-GB transzgént hordozókhoz képest. A K5Q módosítást hordozó állatok kis mértékben mutattak rosszabb kikelési arányt, K12R és K12Q módosításokat hordozó egyedek pedig egyáltalán nem keltek ki. A K5R, K8R, K12R és K12Q módosítások esetén az életképesség csökkenés szignifikáns (t-próba: K5R $\mathrm{P}=0,0025, \mathrm{~K} 8 \mathrm{R}-\mathrm{P}=0,0289, \mathrm{~K} 12 \mathrm{R}-\mathrm{P}=0,0013, \mathrm{~K} 12 \mathrm{Q}-\mathrm{P}=0,0013)$. A lizin-arginin (K$\mathrm{R}$, vagyis módosítatlan lizint mimikáló) módosítás minden esetben gyengébb életképességet eredményezett a többi kategóriánál (30. ábra). 


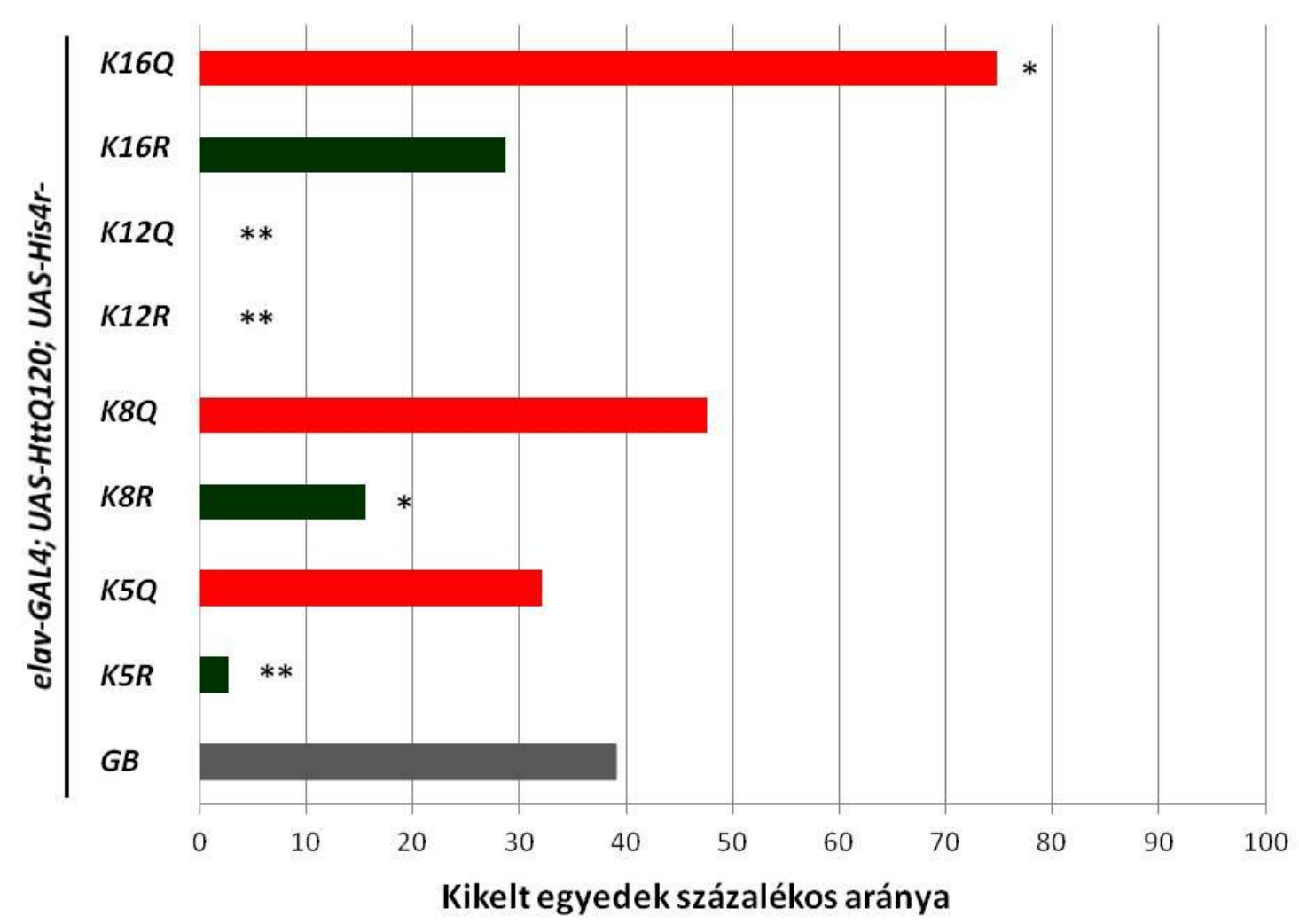

30. ábra. A His4r transzgének neuronális expressziójának hatása az életképességre Drosophila Huntington-kór modellben. A mHtt-t (UAS-HttQ120) és transzgenikus UAS-His4r szubsztitúciókat hordozó (K5R, K5Q, K8R, K8Q, K12R, K12Q, K16R, $\mathrm{K} 16 \mathrm{Q})$, és vad típusú $U A S$-His4r transzgént expresszáló (GB) törzsek életképesség adatai. A módosított UAS-His4r-t $m H t t$ háttéren elav-GAL4 driverrel neuronálisan expresszáló állatok kikelési aránya látható saját $U A S$-His $4 r$ transzgént nem, csak $m H t t$-t expresszáló belső „beteg” kontrolljaikhoz viszonyítva (a nem expresszáló „egészséges” kontrollok nincsenek ábrázolva). A statisztikai értékelés Student t-próbával történt, ahol a *: P < 0,05, **: P < 0,01. A vad típusú His4r-GB expresszió is kb. 60\%-os életképesség csökkenéshez vezetett. Ennél kisebb mértékü életképesség csökkenést okozott a K8Q és K16Q módosítás, melyek közül a K16Q szignifikáns javulás.

\section{IV.2.5.b. His4r pontmutációk hatása a mutáns Htt kiváltotta csökkent élettartamra}

$\mathrm{Az}$ életképes, $m H t t$-t és UAS-His4r transzgént együtt expresszáló utódkategóriákon élettartam vizsgálatot is végeztünk (a K12-es módosításokat hordozó utódkategóriák nem bizonyultak életképesnek). Az UAS-His $4 r$ transzgént nem, csak $m H t t$-t expresszáló egyedek élettartamát egyik His4r szubsztitúciót hordozó kategória sem haladta meg. Viszont az elmondható, hogy a His4r-GB-t (módosítatlan transzgént) expresszáló egyedeknél a K8Q és K16Q módosítást hordozók hosszabb élettartamot mutattak (31. ábra). A His4r-K8Q-t expresszáló egyedek szignifikáns élettartam javulást mutatnak a His4r-GB-t expresszálóakhoz képest minden vizsgált mortalitási értéknél, valamint a $H i s 4 r-K 8 R$-t expresszáló kategóriánál 
is a $25 \%$-os mortalitási értéknél. A His $4 r-K 16 Q$-t expresszáló egyedek pedig a His $4 r$-GB-t expresszáló kategóriához képest nem, azonban a His4r-K16R-hez képest szignifikáns javulást mutat élettartamát tekintve a 25, 50 és 75\%-os mortalitási értéknél (3. táblázat).
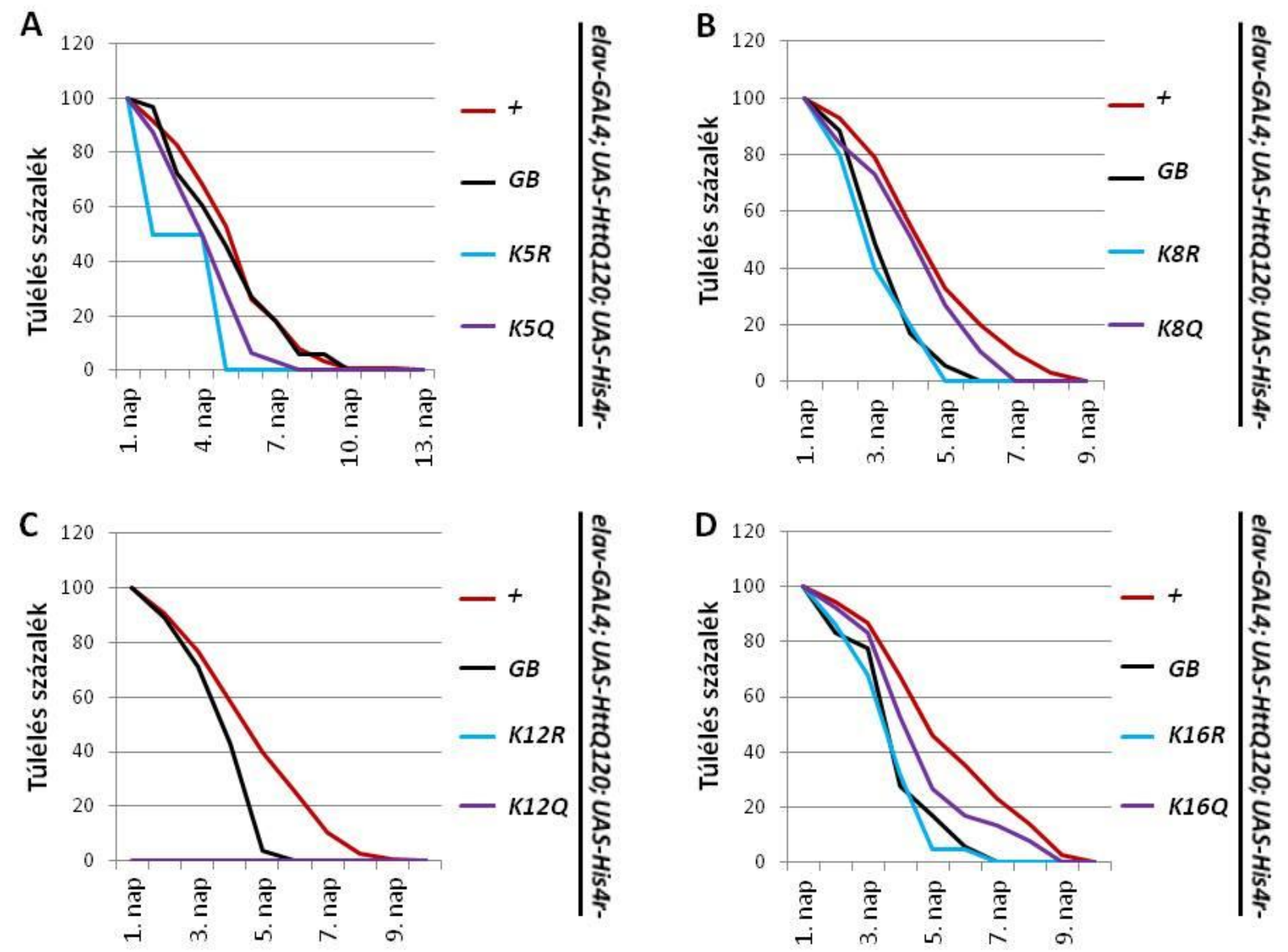

31. ábra. A His4r transzgének neuronális expressziójának hatása az élettartamra Drosophila Huntington-kór modellben. A $m H t t-t$ (UAS-HttQ120) és transzgenikus UAS-His4r szubsztitúciókat hordozó (K5R, K5Q (A), K8R, K8Q (B), K12R, K12Q (C), K16R, K16Q (D)), és vad típusú His4r transzgént expresszáló (GB) törzsek élettartam görbéi. A módosított UAS-His4r-t $m H t t$ háttéren elav-GAL4 driverrel neuronálisan expresszáló állatok élettartama látható csak $m H t t$-t expresszáló belső kontrolljaikhoz (+) és $m H t t$ mellett His $4 r$-GB-t expresszáló (GB) kontrollhoz viszonyítva külön minden vizsgált pozícióra. A vad típusú His4r-GB expresszió is jelentős élettartam csökkenéshez vezetett, melyet enyhít a K8Q és K16Q módosítás. 


\begin{tabular}{|c|c|c|c|c|c|}
\hline & Összehasonlított genotípusok & $\begin{array}{c}\text { P-érték } \\
25 \%-o s \\
\text { mortalitás- } \\
\text { nál }\end{array}$ & $\begin{array}{c}\text { P-érték } \\
50 \%-\text { os } \\
\text { mortalitás- } \\
\text { nál }\end{array}$ & $\begin{array}{c}\text { P-érték 75\%- } \\
\text { os } \\
\text { mortalitás- } \\
\text { nál }\end{array}$ & $\begin{array}{c}\text { P-érték } \\
90 \%-0 s \\
\text { mortalitás- } \\
\text { nál }\end{array}$ \\
\hline \multirow{6}{*}{ K5 } & $\begin{array}{c}\text { elav-GAL4/w; UAS-HttQ120/+; Sb/+ v.s. } \\
\text { elav-GAL4/w; UAS-HttQ120/+; UAS-His4r-GB/+ }\end{array}$ & 0,5457 & 0,9966 & 0,9248 & 0,7504 \\
\hline & $\begin{array}{c}\text { elav-GAL4/w; UAS-HttQ120/+; Sb/+ v.s. } \\
\text { elav-GAL4/w; UAS-HttQ120/+; UAS-His4r-K5R/+ }\end{array}$ & 0,271 & 0,4133 & 0,5164 & 0,7026 \\
\hline & $\begin{array}{c}\text { elav-GAL4/W; UAS-HttQ120/+; Sb/+ V.S. } \\
\text { elav-GAL4/W; UAS-HttQ120/+; UAS-His4r-K5Q/+ }\end{array}$ & 0,0093 & 0,0081 & 0,0141 & 0,1007 \\
\hline & $\begin{array}{c}\text { elav-GAL4/w; UAS-HttQ120/+; UAS-His4r-GB/+ v.s. } \\
\text { elav-GAL4/w; UAS-HttQ120/+; UAS-His4r-K5R/+ }\end{array}$ & 0,3655 & 02513 & 0,5511 & 0791 \\
\hline & $\begin{array}{c}\text { elav-GAL4/w; UAS-HttQ120/+; UAS-His4r-GB/+ v.s. } \\
\text { elav-GAL4/w; UAS-HttQ120/+; UAS-His4r-K5Q/+ }\end{array}$ & 0,1531 & 00696 & 00231 & 0,1671 \\
\hline & $\begin{array}{c}\text { elav-GAL4/w; UAS-HttQ120/+; UAS-His4r-K5R/+ v.s. } \\
\text { elav-GAL4/w; UAS-HttQ120/+; UAS-His4r-K5Q/+ }\end{array}$ & 0,5971 & 0,4196 & 0,7878 & 0,7878 \\
\hline \multirow{6}{*}{ K8 } & $\begin{array}{c}\text { elav-GAL4/W; UAS-HttQ120/+; Sb/+ V.S. } \\
\text { elav-GAL4/W; UAS-HttQ120/+; UAS-His4r-GB/+ }\end{array}$ & 0,000041 & 0,0001 & 0,0015 & 0,0605 \\
\hline & $\begin{array}{c}\text { elav-GAL4/W; UAS-HttQ120/+; Sb/+ v.S. } \\
\text { elav-GAL4/W; UAS-HttQ120/+; UAS-His4r-K8R/+ }\end{array}$ & 0,0067 & 0,0364 & 0,1199 & 0,3164 \\
\hline & $\begin{array}{c}\text { elav-GAL4/w; UAS-HttQ120/+; Sb/+ v.s. } \\
\text { elav-GAL4/w; UAS-HttQ120/+; UAS-His4r-K8Q/+ }\end{array}$ & 0,4392 & 0,3544 & 0,163 & 0,0537 \\
\hline & $\begin{array}{c}\text { elav-GAL4/w; UAS-HttQ120/+; UAS-His4r-GB/+ v.s. } \\
\text { elav-GAL4/w; UAS-HttQ120/+; UAS-His4r-K8R/+ }\end{array}$ & 0,7291 & 0,7291 & 0,9182 & 0,4676 \\
\hline & $\begin{array}{c}\text { elav-GAL4/w; UAS-HttQ120/+; UAS-His4r-GB/+ v.s. } \\
\text { elav-GAL4/W; UAS-HttQ120/+; UAS-His4r-K8Q/+ }\end{array}$ & 0,0029 & 0,0017 & 0,0139 & 0,0484 \\
\hline & $\begin{array}{c}\text { elav-GAL4/W; UAS-HttQ120/+; UAS-His4r-K8R/+ v.s. } \\
\text { elav-GAL4/W; UAS-HttQ120/+; UAS-His4r-K8Q/+ }\end{array}$ & 0,0285 & 0,052 & 0,0715 & 0,2944 \\
\hline \multirow{6}{*}{ K16 } & $\begin{array}{c}\text { elav-GAL4/W; UAS-HttQ120/+; Sb/+ V.S. } \\
\text { elav-GAL4/w; UAS-HttQ120/+; UAS-His4r-GB/+ }\end{array}$ & 0,0022 & 0,0128 & 0,0293 & 0,4734 \\
\hline & $\begin{array}{c}\text { elav-GAL4/W; UAS-HttQ120/+; Sb/+ V.S. } \\
\text { elav-GAL4/W; UAS-HttQ120/+; UAS-His4r-K16R/+ }\end{array}$ & 0,0005 & 0,0006 & 0,0163 & 0,4257 \\
\hline & $\begin{array}{c}\text { elav-GAL4/W; UAS-HttQ120/+; Sb/+ v.s. } \\
\text { elav-GAL4/W; UAS-HttQ120/+; UAS-His4r-K16Q/+ }\end{array}$ & 0,0334 & 0,0258 & 0,1877 & 0,2109 \\
\hline & $\begin{array}{c}\text { elav-GAL4/w; UAS-HttQ120/+; UAS-His4r-GB/+ v.s. } \\
\text { elav-GAL4/w; UAS-HttQ120/+; UAS-His4r-K16R/+ }\end{array}$ & 0,6874 & 0,9865 & 0,2399 & 0,914 \\
\hline & $\begin{array}{c}\text { elav-GAL4/w; UAS-HttQ120/+; UAS-His4r-GB/+ v.s. } \\
\text { elav-GAL4/w; UAS-HttQ120/+; UAS-His4r-K16Q/+ }\end{array}$ & 0,0775 & 0,0775 & 0,3221 & 0,1101 \\
\hline & $\begin{array}{l}\text { elav-GAL4/w; UAS-HttQ120/+; UAS-His4r-K16R/+ v.s. } \\
\text { elav-GAL4/w; UAS-HttQ120/+; UAS-His4r-K16Q/+ }\end{array}$ & 0,0434 & 0,0434 & 0,0329 & 0,0776 \\
\hline
\end{tabular}

3. táblázat. mHtt-t és pontmutáns His4r transzgéneket expresszáló Drosophilák esetében meghatározott mortalitási arányokhoz tartozó szignifikancia értékek. Zöld színnel kiemelve láthatóak azok az adatok, ahol az UAS-His4r transzgént expresszáló utódok élettartama szignifikánsan rosszabbnak bizonyult a csak mHtt-t (UAS-HttQ120) expresszáló kategóriához képest, pirosan az olyan szignifikáns javulás látható, ahol valamelyik UAS-His4r expresszió jobbnak bizonyult egy másiknál. A különbségek statisztikai értékelése Mann-Whitney U teszttel történt.

\section{IV.2.5.c. His4r pontmutációk hatása a mutáns Htt kiváltotta neurodegenerációra}

A már korábban ismertetett pseudopupil assay alkalmazásával teszteltük van-e a különböző $U A S-H i s 4 r$ transzgének neuronális expressziójának hatása a Huntington-kór okozta idegsejt degenerációra. A vizsgálatot azokkal a pontmutáns transzgénekkel (UAS-His4r-GB, K5Q, $K 8 R, K 8 Q, K 16 R, K 16 Q)$ tudtam elvégezni, amelyek a $m H t t$-el együtt kifejeztetve nem okozták az állatok pusztulását. A kísérletet 2 és 4 napos állatokon végeztem. A 2 napos egyedek esetén a His $4 r$ transzgént expresszáló kategóriáknál az ommatidumonkénti rhabdomerek számának átlag értékei szinte egyik esetben sem mutattak jelentős eltérést a csak $m H t t$-t expresszáló belső kontrolljukhoz képest, kivéve a K5Q módosítást hordozók, ahol kismértékü, ám szignifikáns javulás látható a neurodegenerációban (t-próba: $\mathrm{P}=0,01226$ ) (30. ábra (A)). A 4 napos egyedeken végzett kísérlet valamelyest eltérő eredményt ad a 2 naposokon végzetthez képest. A His $4 r$-K5Q mellett a His4r-K16R és His4r-K16Q transzgén 
expressziója is szignifikáns változást mutat a csak $m H t t$-t expresszáló belső kontrolljához képest (t-próba K5Q: $\mathrm{P}=0,04337, \mathrm{~K} 16 \mathrm{R}: \mathrm{P}=0,003, \mathrm{~K} 16 \mathrm{Q}: \mathrm{P}=0,03393$ ) (32. ábra (B)).

A

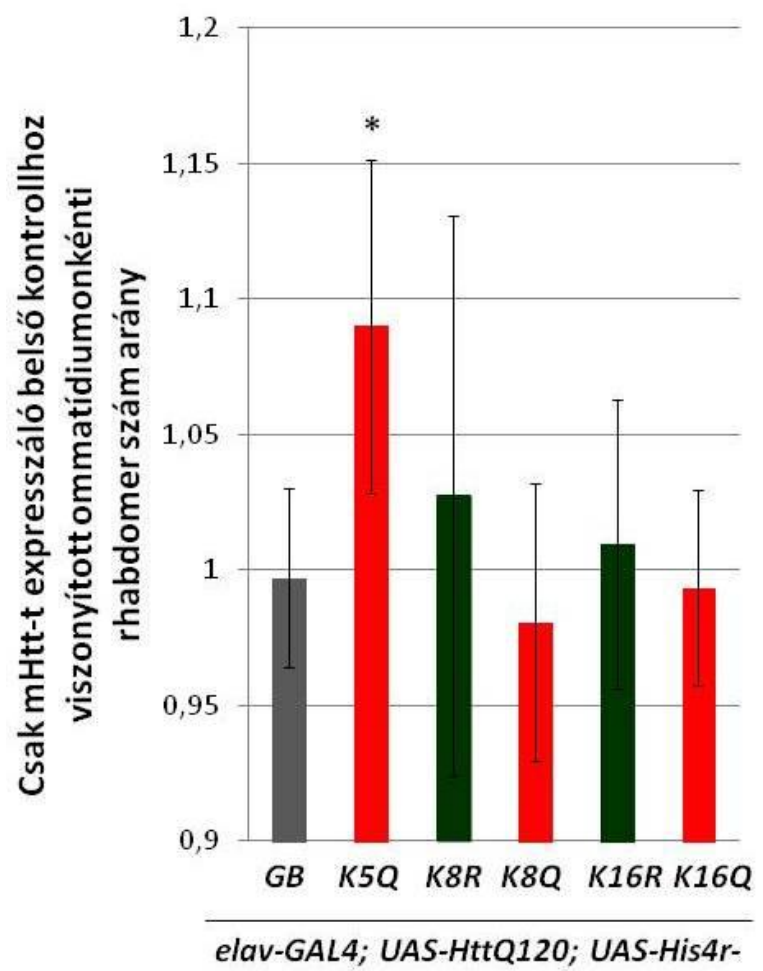

B

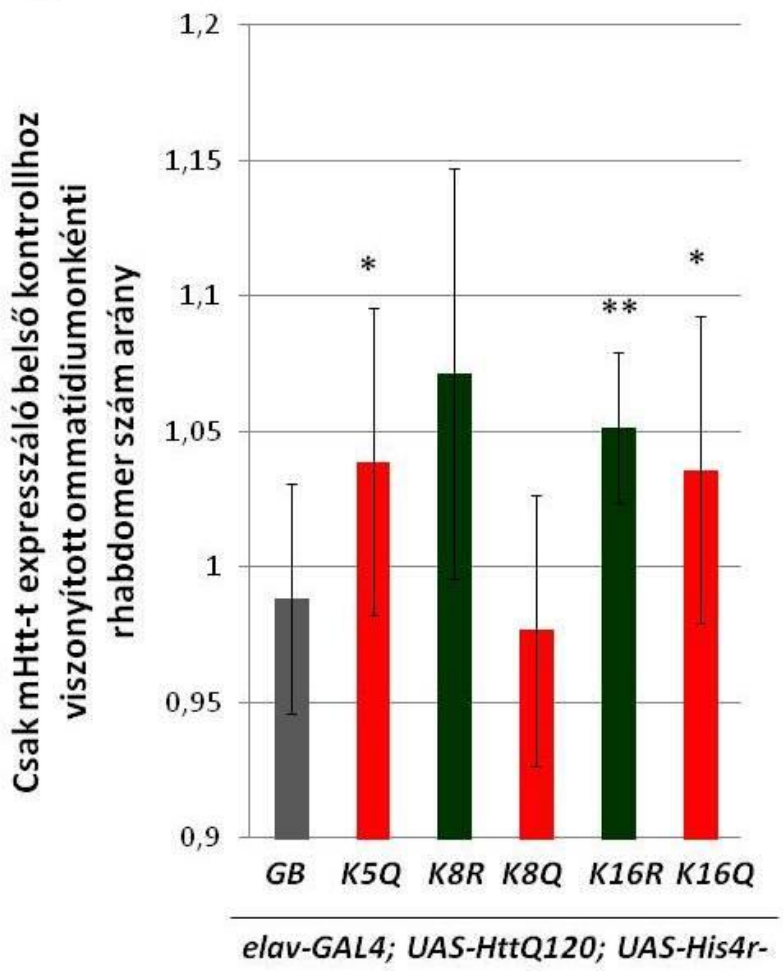

32. ábra A His4r transzgének neuronális expressziójának hatása a fotoreceptor neuronok degenerációjára Huntington-kór modellben. A $m H t t$-t (UAS-HttQ120) és transzgenikus UAS-His4r szubsztitúciókat hordozó (K5Q, K8R, K8Q, K16R, K16Q), illetve $m H t t$-t és vad típusú UAS-His4r transzgént expresszáló (GB) törzsek neurodegenerációs vizsgálata. A diagramokon az UAS-His $4 r$ transzgént és $m H t t$ - $\mathrm{t}$ együttesen expresszáló egyedek ommatídiumonkénti rhabdomer számának aránya látható csak $m H t t$-t expresszáló belső kontrolljaikhoz viszonyítva. Az A panelen 2 napos, a B panelen 4 napos egyedek adatai kerültek ábrázolásra. Az ommatídiumonkénti rhabdomer szám a vad típusú His4r-GB expresszió esetén nem tér el szignifikánsan a „,beteg” kontrollétól. Ennél kisebb mértékü rhabdomer szám csökkenést okozott a K5Q, a K16R és K16Q módosítás expressziója. 


\section{Diszkusszió}

Huntington-kór esetében a mutáns Huntingtin fehérje első exonjában lévő instabil, polimorf $\mathrm{CAG}$ trinukleotid ismétlődés expanziója funkciónyeréses mutációhoz vezet, a fehérje N-terminálisház közel egy patológiás hosszúságú poliglutamin ismétlődés jön létre. A nagyméretü Huntingtin fehérje főként a citoplazmában található meg, azonban mutáns formájából hibás proteolítikus hasítások következtében olyan N-terminális fragmentek keletkeznek, melyek bejutnak a sejtmagba. A mHtt képes kölcsönhatásokat kialakítani más fehérjékkel, melyek csapdázódhatnak az aggregátumokba és így nem képesek funkciójuk betöltésére. Ilyen ismert fehérjék a CBP/p300 és Pcaf hiszton acetiltranszferázok, melyek nem megfelelő müködése acetilációs zavart okoz. ${ }^{295} 296236$

Tekintve, hogy a betegség jelenleg gyógyíthatatlan és csak a tüneti kezelésre van lehetőség célunk volt a kór patogenezisére potenciálisan jótékony hatású epigenetikai targetek keresése. Kísérleteinkhez olyan Drosophila melanogaster törzseket használtunk, amelyek a humán Huntingtin fehérje 1-es exonját hordozzák 120 glutamint tartalmazó poliglutamin szakasszal. A transzgén expresszióját neuronális elav-GAL4 driverrel indukáltuk. A hosszú glutamin szekvenciát hordozó fehérjék aggregátumokat képeznek az agyban és ennek hatására az egyedek mutatják a Huntington-kór jellegzetes tüneteit, úgymint mozgási és aktivitásbeli defektusok, cirkadián-ritmus eltérések, neuronális pusztulás, rövid élettartam. ${ }^{297} 298$

A Drosophila Hat1 általános jellemzése és funkciójának vizsgálata a Huntington-kór pathogenezisében

A Hat1 Drosophilában egy még kevéssé jellemzett aktivitású hiszton acetiltranszferáz enzim. Funkcionális elemzéséhez létrehoztunk egy funkció vesztéses mutáns vonalat. Bár a létrehozott deléció nem terjed ki a teljes génre, a kódoló szekvencia megközelítőleg 80\%-a beleértve a katalítikus aktivitásért felelős domént - elveszett.

A Hat1 targetjeinek azonosításához western blot analízist végeztünk, melynek során megállapítottuk, hogy ortológjaihoz hasonló módon H4K5 és H4K12 acetilációs aktivitással rendelkezik. Drosophilában nem csak ez az egyetlen hiszton acetiltranszferáz enzim mutat ilyen szubsztrát specifitást, L3 lárvában hasonló aktivitást mutattak ki korábban a GCN5 acetiltranszferázt tartalmazó ATAC komplex esetén is. ${ }^{299}$ Adataink alapján azonban a H4K5 és H4K12 acetilációt embriókban egyedül a Hat1 tartja fenn, ugyanis a Hat1 deléciós embriókban kevesebb, mint 4\%-ra csökkent a H4K5 és H4K12 acetiláció szintje a vad típusú embriókhoz képest. Ez az acetilációs tevékenység az érintett lizinekre nézve specifikusnak tünik, ugyanis a Hat1 deléció a H4K8 acetilációra nem volt hatással.

A H3 hiszton acetilációját is vizsgálat alá vettük, ugyanis egy korábban megjelent értekezés szerint egér embrionális fibroblaszt sejtekben a Hat1 mutáció hatással volt a H3 hisztonon megjelenő acetilációra is és H3K9, H3K18, H3K27 acetilációs szintbeli változást okozott. Jelentős csökkenést mutatott az állandó H3K18 acetilációs szint és a replikáció során beépített hisztonokon lévő H3K18 acetiláció is, míg például a H3K23 acetiláció nem volt érzékeny a Hat1 hiányára. ${ }^{179} \mathrm{Az}$ általunk kapott eredmények alátámasztják ezeket az 
adatokat, ugyanis a Hatl deléciós mutáns Drosophila embriókban szignifikánsan csökkent a H3K18 acetilációs szint, míg a H3K23 acetilációban nem történt változás a vad típusú embriókhoz képest. Ezért annak ellenére, hogy a Hat1 nem rendelkezik H3 specifikus katalítikus aktivitással ${ }^{85}{ }^{175}$, úgy tünik, hogy indirekt módon a Hatl befolyásolja a H3 hiszton acetilációs szintjét is.

A H4 hiszton K5 és K12 diacetilációjának olyan funkciót tulajdonítanak, hogy a hisztonok nukleáris importjában és a kromatin összerendeződésben tölthet be szerepet. A H3 és H4 hisztonok karyopherin fehérjék közvetítésével jutnak a sejtmagba, és a H3, H4 N-terminális részek redundánsnak tünnek a nukleáris transzport folyamat során. ${ }^{112}$ Saccharomyces cerevisiae-ben a H4 K5 és K12, illetve a H4 K5, K8 és K12 pozíciók szimultán mutációja glutaminra azt eredményezte, hogy a $\mathrm{H} 4$ citoplazmatikus miszlokalizációt mutatott, míg arginire mutáltatásuk esetén nem volt ez a hatás megfigyelhető. ${ }^{300}$ Ezen adatok alapján a H4 N-terminális részének pozitív töltése elősegíti az NLS funkciót és annak acetilációs állapota hatással van a H4 nukleáris transzportjára, azonban ezek a poszttranszlációs módosítások nem esszenciálisak az import folyamat során. Hat1 null mutáns egér embrionális fibroblaszt sejtekben nem volt kimutatható eltérés sem a citoszolikus, sem a nukleáris H4 hiszton szintben, ami alátámasztja azt a feltevést, hogy a Hat1 által létrehozott acetilációs jelek nem szükségesek a nukleáris importhoz. ${ }^{172} \mathrm{Az}$ általunk kivitelezett kísérlet alátámasztja ezt, ugyanis a His4r variáns hiszton fehérje (amely aminosav szekvencia szinten megegyezik a H4 hisztonnal) Hat1 hiányában is sejtmagi lokalizációt mutatott. Továbbá azon His4r fehérjék, melyeknek a K5 és K12 pozíciói argininre voltak cserélve, szintén bejutottak a sejtmagba. Egyes eredmények szerint a H4 K5 és K12 acetiláció inkább gátolja, mintsem elősegíti a nukleáris importot. ${ }^{300} 112$ Így elképzelhető, hogy a Hatl általi acetiláció a H4 hiszton karyopherin kötéséből való felszabaduláshoz kellhet a sejtmagba jutást követően vagy a kromatin összerendező faktorokhoz történő kötődéshez, és ezáltal a kromatinba épülés elősegítésében játszhat szerepet.

Drosophilában a Hat1 részt vesz a CENP-A (centromere protein A) centromerikus $\mathrm{H} 3$ hiszton fehérje variáns kromatinba helyezésében, ahol a Hat1 komplexet alkot CENP-A, H4 és Caf1-p55 (Hat2 homológ) fehérjékkel. Bár a Hat1 nem acetilálja a CENP-A-t, annak RNSi általi csendesítése mégis a kromatinba épített CENP-A szignifikáns csökkenéséhez vezetett S2 sejtekben. ${ }^{175}$ Saját adataink azt látszanak alátámasztani, hogy bár a H4K5 és K12 diacetiláció hozzájárulhat a nukleáris transzporthoz vagy az általános kromatin összerendeződéshez, nem játszik nélkülözhetetlen szerepet ezekben a folyamatokban. Annak ellenére, hogy Drosophila embriókban egyedül a Hat1 felelős a H4K5 és H4K12 acetilációért, a fehérje nem esszenciális. A Hatl deléció nem okoz fertilitási zavarokat és csak kis mértékben csökkenti az életképességet. Előfordulhat redundancia funkcióit tekintve, feltehetően ezért nem letális a hiánya.

A H4 K5 és K12 diacetiláció részt vesz a DNS kettős szál törés utáni Asf1 (anti-silencing factor 1)-függő kromatin újra-rendeződésben ${ }^{301}$, azonban úgy tünik, hogy a kromatin összerendeződésben nem játszik nélkülözhetetlen szerepet. ${ }^{302} 303$ Humán MCF7 (adenokarcinóma mellrák sejtvonal) sejtekben felfedezték azonban, hogy a Hat1 által létrehozott acetilációnak szerepe van a megfelelő replikációban, ugyanis az ATAD2 (ATPase chromatin AAA domain-containing protein 2) - amely szükségesnek tünik a PCNA 
(Proliferating cell nuclear antigen) megfelelő lokalizációjához a kromatinon és ezzel a hatékony replikációhoz - köti a K5 és K12 diacetilált H4-et, és a naszcens kromatinhoz toborozza. ${ }^{304}$ Hat1 null mutáns egér embrionális fibroblaszt sejtekben számos bromodomént tartlamazó fehérje depletált, míg a Topoizomeráz $2 \alpha$ és $2 \beta$ szintje megemelkedik. ${ }^{172} \mathrm{~A}$ topoizomerázok és a PCNA megváltozott jelenléte utalhat kromatin szerveződésbeli hibára a Hat1 hiánya esetén, melyet saját kísérleteink is alátámasztani látszanak. Pozíció effektus variegációs teszttel kimutattuk, hogy a Hat1 részt vehet a zárt kromatin szerkezet kialakításában és fenntartásában. Ezért a Hatl deléció génexpresszióban megnyilvánuló hatásait is vizsgáltuk Drosophila embriókban. Érdekes módon azt tapasztaltuk, hogy több, mint 2000 gén expressziós szintje mutatott szignifikáns változást vad típusú embriókhoz képest. Ezen eltérések kétharmada megemelkedett génexpressziót (upregulációt), egyharmada pedig csökkent génexpressziót (downregulációt) mutatott. Ezeket az adatokat összehasonlítva a modENCODE fejlődési RNS szekvencia adataival $288 \quad 292$ azt találtuk, hogy a Hat1 mutánsokban emelkedett expressziót mutató gének nagy része korai embriókban mutat magasabb expressziót, míg a csökkent expressziót mutató gének többsége későbbi embrionális stádiumokban rendelkezik magasabb expressziós szinttel. Ez alapján arra a következtetésre jutottunk, hogy a változások nagy része egy fejlődési késés következménye lehet, feltételezhetően egy replikációra és/vagy kromatin érésre kifejtett negatív hatás eredményeként. Azok közül a gének közül, amelyeknek expressziós változása nem magyarázható ezzel a fejlődési csúszással (a változást mutató gének kb. 17\%-a), a Hat1 deléciós mutáns embriókban megemelkedett génexpressziót mutatók többnyire egyedfejlődési folyamatokban, míg a csökkent génexpressziót mutatók metabolikus folyamatokban résztvevő faktorok.

Kísérletsorozatunkban vizsgáltuk azt is, hogy a Hat1 hiszton acetiltrenszferáz enzimnek van-e valamilyen hatása a mutáns Huntingtin fehérje kiváltotta neurodegenerációra a Huntington-kór Drosophila modelljében, mivel bár a hiszton acetilációnak a betegségben játszott szerepét régóta vizsgálják, a Hatl szerepére vonatkozó kísérleti adatok nem álltak rendelkezésre. A Hatl delécióval kapcsolatos eredményeink alapján elképzelhető, hogy mint az más tanulmányokban is szerepelt és amint saját kromatin szerveződési vizsgálatunk - mely szerint a Hat1 PEV szuppresszor hatású - is alátámasztani látszik, a Hat1 egy zártabb kromatin szerkezet kialakításában vagy fenntartásában vehet részt. Ez lehet az oka annak, hogy a Hat1 részleges hiánya csökkentette a Huntington-kór kiváltotta neurodegeneráció mértékét. Ez a neuronális túlélésre kifejtett hatás ellentétes irányú a nukleáris hiszton acetiltranszferázoknak (dCBP/nejire és Pcaf/gcn5) a Huntington-kór modellekben megfigyelt hatásával. ${ }^{293}{ }^{296}$ Feltételezésünk szerint a Hatl deléció következtében jelenlévő csökkent H4K5 és K12 acetiláció olyan módon lehet pozitív hatással a neurodegenerációra Huntingtonkór modellben, hogy mint azt a His4r kísérleteinkben tapasztaltuk, a nem acetilált hiszton fehérjék magasabb szinten vannak jelen a sejtekben és az acetiláció hiányában előfordulhat, hogy ezeknek a hiszton fehérjéknek a kromatinba épülése lassul, vagy gátolt, ami magyarázhatja az általunk vizsgált Hatl deléciós embriók fejlődési csúszását is, illetve a pozíció effektus variegációs tesztjeink során tapasztalt nyitottabb kromatin szerkezetet is. Elképzelhető, hogy ebben föként a K12 acetilációnak lehet szerepe és ezért volt a 
feltételezhetően aktív transzkripciós helyeken szerepet játszó His4r fehérje K12 módosításainknak letális hatása muslica HD modellben.

$\underline{\text { His4r variáns hiszton fehérjék acetilációs módosításainak hatása Huntington-kór modellben }}$

Egyes hiszton deacetiláz enzimek gátlása enyhítő hatással van a Huntington-kór modellekben megfigyelhető fenotípusokra 259260256255252254 , feltehetően legalább részben a hiszton fehérjék acetilációs szintjének módosítása által. Az azonban nem feltárt, hogy mely hisztonok melyik aminosavainak módosításai bírnak jelentősséggel ebben a folyamatban. Ezért célul tüztük ki, hogy megvizsgáljuk a H4 hisztonnal megegyező aminosav sorrendü His4r hiszton különböző acetilációs állapotainak hatását a Huntington-kór muslica modelljében.

Annak vizsgálatára, hogy a hiszton deacetilázok gátlása esetén, és saját kísérleteinkben a Hat1 hiánya esetén, a mutáns Htt okozta tünetek enyhülésében mely hiszton pozícióra gyakorolt hatás játszhat szerepet, olyan kísérletet terveztünk, melynek során a His4r hiszton fehérje egyes acetilálható lizinjeinek szerepét vizsgáltuk pontmutációk segítségével. Glutamin cserével acetilált, arginin cserével pedig módosítatlan lizineket mimikáltunk az 5-ös, 8-as, 12 es és 16-os pozíciókban. Választásunk azért esett a His4r fehérje vizsgálatára, mert aminosav szekvenciája megegyezik a kanonikus H4 hiszontéval, azonban a kanonikus génklaszteren kívül, csak egy kópiában található meg a genomban és a hiszton gén klaszterben található hisztonoktól eltérően kifejeződése nem kapcsolt a replikációval. Az általunk vizsgálni kívánt módosításokat hordozó His4r pontmutáns vektor konstrukciókat úgy terveztük meg, hogy tartalmazzák az intronikus régiókat, hogy a His4r-nek a kanonikus H4 hiszton fehérjétől esetlegesen eltérö, splicing szintjén megvalósuló expressziós szabályozása megmaradjon. A H3.3 hiszton variánsok esetén megfigyelhető, hogy a kanonikus H3 hisztont a transzkripciósan aktív génszakaszokon cserélik le ${ }^{294}$. Feltételezzük, hogy ez a H4 - His4r fehérjékre is igaz lehet, azaz, hogy a His4r lecserélheti a H4 hisztont posztreplikatív sejtekben az akítv géneken. Azt feltételeztük, hogy ezen tényezők következtében az életképességet kevéssé befolyásoló, elsősorban az aktív génekre korlátozott hatású, jól vizsgálható modell rendszert hozunk létre.

Az UAS-His4r pontmutáns transzgéneket hordozó Drosophila törzseket validáltuk a beépült transzgén szekvenálásával, az RNS és fehérje expressziójuk szintjének tesztelésével és az expresszált fehérjék sejten belüli lokalizációjának vizsgálatával. A szekvenciák minden esetben hordozták a megfelelő szubsztitúciót. Az RNS expresszió a transzgénekről megfelelő volt és nem mutatott egymáshoz képest számottevő eltérést. Azonban a fehérje expressziós szint vizsgálata során azt az érdekes eredményt kaptuk, hogy az acetilációt mimikáló módosítások minden esetben alacsonyabb fehérje szintet mutattak a módosítatlan lizint mimikáló argininnel helyettesített változatuknál. Ennek oka valószínüleg valamilyen fehérje stabilitási eltérés, a módosítás következtében megváltozhatott a fehérjék expressziója vagy féléletideje. Ennek ellenére a fehérje lokalizációs vizsgálat minden esetben azt mutatta, hogy a His4r transzgenikus fehérjék bejutnak a sejtmagba.

A H4 N-terminális része szerepet játszik a nukleáris transzport folyamatban. A H3 és H4 kompetál a Kap123 / IPO4 importinhoz kötődésben. A H4 K16 a második lizin-kötő zsebhez 
képes kapcsolódni és ennek a pozíciónak a glutaminra változtatása, vagyis a pozitív töltés semlegesítése, csökkenti a H4 affinitását az inportinhoz. A H4 K5 és K12 hasonló mutációja még jobban lecsökkenti a H4 affinitását a Kap123 / IPO4 -hez, tehát ezek a pozíciók szintén szerepet játszanak a karyopherin felismerésben. ${ }^{112}$ Egyes eredmények szerint a H4 K5 és K12 acetiláció inkább gátolja, mintsem elősegíti a nukleáris importot. ${ }^{300} 112$ Amennyiben a H4 Nterminális lizinjeinek acetilált állapota akadályozza a nukleáris transzport folyamatot, az magyarázatul szolgálhat arra, hogy az acetilációt mimikáló módosítások miért vannak alacsonyabb mennyiségben jelen a sejtekben western blot eredményeink szerint. Elképzelhető, hogy ezeknek a fehérjéknek gyorsabb a lebontása, hogy ne akadályozzák a H3:H4 komplexek sejtmagba jutását.

A validálást követő első kísérleteink a transzgének fenotípusra gyakorlot hatásának tesztelésére irányultak. Az UAS-His4r transzgének neuronális expressziójának nem volt hatása az egyedek életképességére és önmagukban nem okoztak retinális neuronpusztulást. Tehát a Huntington-kór Drosophila modelljében való tesztelés során tapasztalható fenotípusbeli eltérések a betegségre kifejtett specifikus hatásnak tulajdoníthatóak.

A mutáns Huntingtin ( $m H t t$ - UAS-HttQ120) és UAS-His4r transzgént együttesen expresszáló egyedeken életképesség, élettartam és neurodegenerációs vizsgálatot hajtottunk végre. A $m H t t$ és az UAS-His4r együttes expressziójának hatására romlott az egyedek életképessége, a csak $m H t t$-t expresszáló „,beteg” kontroll állatokhoz képest. Azonban a vad típusú $U A S-H i s 4 r$ és $m H t t$ transzgént expresszáló kategóriánál jobb életképességet és hosszabb élettartamot mutattak a K8Q és K16Q módosításokat hordozó UAS-His4r transzgént expresszáló egyedek. A neurodegenerációs vizsgálat során a K5Q, K16Q és K16R módosítások mutattak pozitív hatást.

Eredményeink azt mutatják, hogy a K5R módosítás szignifikánsan rontotta az életképességet Drosophila HD modellben, a K5Q módosítás pedig szignifikánsan jótékony hatással volt a neurodegenerációra (a K5R módosítás hatásának vizsgálatát a neurodegenerációra nem tudtuk elvégezni az egyedek nagymértékü életképesség és élettartam csökkenése miatt). A H4K5 acetilációról egérben leírták, hogy szerepet játszik a memória folyamatokban és a H4K5ac korrelál a hippokampuszban a génexpresszióval. ${ }^{305}$ Ami magyarázatul szolgálhat arra, hogy a His4r-K5Q acetilációt mimikáló módosítás neuronális expressziója pozitív hatással volt a Huntington-kór okozta acetiláció csökkenésre.

A K8R módosítás HD modellben az egyedek szignifikáns életképesség csökkenését okozta, míg a K8Q módosítás javított az egyedek életképességén és élettartamán is. A H4K8 acetilációról leírták, hogy szükséges a kromatin dekompaktálódáshoz a replikáció során, ugyanis $S$. pombe-ban a $\mathrm{H} 4 \mathrm{~K} 8 \mathrm{R}$ hiszton expresszió részlegesen akadályozta a kromatin dekondenzációt. ${ }^{306}$ Ez magyarázhatja a His4r-K8Q acetilációt mimikáló módosítás pozitív hatását, ami lehetséges, hogy Huntington-kór kiváltotta transzkripcionális diszreguláció mérséklésén keresztül valósul meg.

A H4K12 acetilációról szintén leírták, hogy szükséges a kromatin dekompaktálódáshoz a replikáció során, ugyanis $S$. pombe-ban a H4 K12R hiszton expresszió (a H4 K8R módosításhoz hasonlóan) részlegesen akadályozta a kromatin dekondenzációt. ${ }^{306}$ A H4K12 acetilációs jelet összefüggésbe hozták a kor-függő memória károsodással is. ${ }^{307}$ Továbbá HD 
egér modellben általános H4K12ac csökkenés volt jellemző a hippokampális agyi régiókon, ezért a neuronális H4K12 deacetiláció egy biomarkere lehet a hippokampális degenerációval összefüggésben álló epigenetikai diszregulációnak. ${ }^{263}$ Ezért elképzelhető, hogy a H4K12 dinamikus acetilációs szabályozása olyan fontos szerepet játszik a megfelelő neuronális müködésben, hogy az általunk létrehozott His4r-K12R és K12Q módosítások expressziója ezért nem életképes HD modellben.

A H4K16 pozícióról felfedezték, hogy részt vesz a magasabb szerveződésű kromatin struktúra kialakulásában és acetilációja gátolja többek között a $30 \mathrm{~nm}$-es rost formálódást in vitro. A H4K16ac valószínűsíthetően csökkenti az ISWI kromatin átrendező faktor és a nukleoszóma közötti kölcsönhatást is. ${ }^{308}$ Ezért lehetséges, hogy az általunk vizsgált His4rK16Q módosítás pozitív hatása csak az alacsony fehérje szintnek köszönhető, azonban a His4r-K16R acetilálatlan állapotot mimikáló módosítás expressziójának neurodegenerációt szignifikánsan enyhítő hatása ezen a kromatin szerveződésben betöltött szerepen keresztül hathat.

A CBP/p300 specifikusan acetilálja a $\mathrm{H} 2 \mathrm{~A}$ és $\mathrm{H} 2 \mathrm{~B}$ minden acetilálható pozícióját, a $\mathrm{H} 3$ $\mathrm{K} 14, \mathrm{~K} 18$ (és kisebb mértékben a K23 pozíciót is), valamint a H4 K5, K8 pozíciókat (és kisebb mértékben a K12 és K16 pozíciót is). A Pcaf elsősorban H3K14 acetilációt végez, de H4K8 acetilációs aktivitása is van. ${ }^{309}$ Ezekröl az enzimekről már bizonyítást nyert, hogy szerepet játszanak a Huntington-kór pathogenezisében. A deacetiláz gátlók, amelyek a Sir2 vagy Rpd3 hiszton deacetilázokon keresztül hatva csökkentik a $\mathrm{CBP} / \mathrm{p} 300$ és Pcaf csapdázódása és az acetiláció csökkenése révén kialakuló neurodegeneráció mértékét, elképzelhető, hogy összefüggésbe hozhatóak az általunk vizsgált acetilációt mimikáló His4r transzgének pozitív hatásával, elsősorban a His4r-K8Q módosítással. Így lehetséges, hogy a dCBP és Pcaf által kialakított H4K8 acetiláció fenntartásán keresztül fejtik ki jótékony hatásukat a hiszton deacetiláz gátlók, ami magyarázatul szolgálna a His4r-K8Q expresszió pozitív és a His4r-K8R módosítás életképességet és élettartamot negatívan befolyásoló hatására Drosophila HD modellben.

A Huntington-kór okozta hiszton acetilációs változások csökkentésére széles spektrumú hiszton deacetiláz gátlókat (fenilbutirát, valproinsav, SAHA) alkalmaznak a klinikumban. Ha a betegség patomechanizmusában szerepet játszó hiszton pozíciókat célzottan lehetne kezelni, az hatékonyabb terápiás lehetőséget nyújthatna kevesebb szükségtelen mellékhatással. A H4 / His4r K8 pozíció lehet egy ilyen potenciális target a jövőben. Továbbá a Hat1 gátlásával feltehetően a kromatin szerkezet nyitotabbá válásán keresztül megvalósuló Huntington-kórra kifejtett neurodegenerációt enyhítő hatás szintén egy hatásos lehetőségnek tünhet. 


\section{Köszönetnyilvánítás}

Köszönettel tartozom témavezetőmnek, Dr. Bodai Lászlónak, hogy irányította munkámat és lehetőséget adott arra, hogy kutatócsoportjában dolgozzak.

Köszönöm Dr. Zsindely Nórának a hasznos szakmai tanácsait, melyekkel segítette kísérleteimet.

Köszönet illeti a kutatócsoport minden jelenlegi és volt tagját, aki segítséget nyújtott munkám során. Közülük is szeretném kiemelni Neller Alexandrát és Korbai Szabinát, akik kísérletesen is hozzájárultak a disszertációm eredményeihez.

Köszönöm továbbá korábbi munkatársaimnak és csoporttársaimnak - Nagy Ágotának, Jipa Andrásnak, Németh Brigittának és Váradi Orsolyának, hogy hasznos ötleteikkel és támogatásukkal segítettek e hosszú út megtétele során.

Mindemellett köszönöm családomnak - Gschwindt Attilának, Varga Dánielnek, Vargáné Koplányi Tündének és Varga Tibornak - a biztatást és támogatást.

A disszertáció alapját képező kutatás a GINOP-2.3.2-15-2016-00032, a GINOP-2.3.2-152016-00034 és az OTKA K-112294 pályázatok támogatásával készült. 


\section{Irodalomjegyzék}

1. Fazary, A. E., Ju, Y.-H. \& Abd-Rabboh, H. S. M. How does chromatin package DNA within nucleus and regulate gene expression? Int. J. Biol. Macromol. 101, 862-881 (2017).

2. Fyodorov, D. V., Zhou, B.-R., Skoultchi, A. I. \& Bai, Y. Emerging roles of linker histones in regulating chromatin structure and function. Nat. Rev. Mol. Cell Biol. 19, 192-206 (2018).

3. Alan Wolffe. Chromatin: Structure and Function. (Elsevier, 2000). doi:10.1016/B978-012-761914-9.X5000-4.

4. Sandman, K., Pereira, S. L. \& Reeve, J. N. Diversity of prokaryotic chromosomal proteins and the origin of the nucleosome. Cell. Mol. Life Sci. CMLS 54, 1350-1364 (1998).

5. Vernet, G., Sala-Rovira, M., Maeder, M., Jacques, F. \& Herzog, M. Basic nuclear proteins of the histone-less eukaryote Crypthecodinium cohnii (Pyrrhophyta): twodimensional electrophoresis and DNA-binding properties. Biochim. Biophys. Acta 1048, 281-289 (1990).

6. Balhorn, R. The protamine family of sperm nuclear proteins. Genome Biol. 8, 227 (2007).

7. van Holde, K. \& Zlatanova, J. The nucleosome core particle: does it have structural and physiologic relevance? BioEssays News Rev. Mol. Cell. Dev. Biol. 21, 776-780 (1999).

8. Marzluff, W. F. \& Duronio, R. J. Histone mRNA expression: multiple levels of cell cycle regulation and important developmental consequences. Curr. Opin. Cell Biol. 14, 692-699 (2002).

9. Dominski, Z. \& Marzluff, W. F. Formation of the 3' end of histone mRNA. Gene 239, 1-14 (1999).

10. Borun, T. W., Gabrielli, F., Ajiro, K., Zweidler, A. \& Baglioni, C. Further evidence of transcriptional and translational control of histone messenger RNA during the HeLa S3 cycle. Cell 4, 59-67 (1975).

11. Arents, G., Burlingame, R. W., Wang, B. C., Love, W. E. \& Moudrianakis, E. N. The nucleosomal core histone octamer at 3.1 A resolution: a tripartite protein assembly and a left-handed superhelix. Proc. Natl. Acad. Sci. U. S. A. 88, 10148-10152 (1991).

12. Luger, K., Mäder, A. W., Richmond, R. K., Sargent, D. F. \& Richmond, T. J. Crystal structure of the nucleosome core particle at 2.8 A resolution. Nature 389, 251-260 (1997).

13. Schroth, G. P., Yau, P., Imai, B. S., Gatewood, J. M. \& Bradbury, E. M. A NMR study of mobility in the histone octamer. FEBS Lett. 268, 117-120 (1990).

14. Fletcher, T. M. \& Hansen, J. C. The nucleosomal array: structure/function relationships. Crit. Rev. Eukaryot. Gene Expr. 6, 149-188 (1996).

15. Arents, G. \& Moudrianakis, E. N. The histone fold: a ubiquitous architectural motif utilized in DNA compaction and protein dimerization. Proc. Natl. Acad. Sci. U. S. A. 92, 11170-11174 (1995). 
16. Burton, D. R. et al. The interaction of core histones with DNA: equilibrium binding studies. Nucleic Acids Res. 5, 3643-3663 (1978).

17. Prunell, A. Nucleosome reconstitution on plasmid-inserted poly(dA) . poly(dT). EMBO J. 1, 173-179 (1982).

18. Widlund, H. R. et al. Identification and characterization of genomic nucleosomepositioning sequences. J. Mol. Biol. 267, 807-817 (1997).

19. Aviles, F. J., Chapman, G. E., Kneale, G. G., Crane- Robinson, C. \& Bradbury, E. M. The Conformation of Histone H5. Eur. J. Biochem. 88, 363-371 (1978).

20. Brown, D. T., Izard, T. \& Misteli, T. Mapping the interaction surface of linker histone H1(0) with the nucleosome of native chromatin in vivo. Nat. Struct. Mol. Biol. 13, 250255 (2006).

21. Thoma, F. \& Koller, T. Influence of histone H1 on chromatin structure. Cell 12, 101107 (1977).

22. Maze, I., Noh, K.-M., Soshnev, A. A. \& Allis, C. D. Every amino acid matters: essential contributions of histone variants to mammalian development and disease. Nat. Rev. Genet. 15, 259-271 (2014).

23. Costanzi, C. \& Pehrson, J. R. Histone macroH2A1 is concentrated in the inactive X chromosome of female mammals. Nature 393, 599-601 (1998).

24. Malik, H. S. \& Henikoff, S. Phylogenomics of the nucleosome. Nat. Struct. Biol. 10, 882-891 (2003).

25. Chen, P. et al. H3.3 actively marks enhancers and primes gene transcription via opening higher-ordered chromatin. Genes Dev. 27, 2109-2124 (2013).

26. Shelby, R. D., Monier, K. \& Sullivan, K. F. Chromatin assembly at kinetochores is uncoupled from DNA replication. J. Cell Biol. 151, 1113-1118 (2000).

27. Yoda, K. et al. Human centromere protein A (CENP-A) can replace histone H3 in nucleosome reconstitution in vitro. Proc. Natl. Acad. Sci. U. S. A. 97, 7266-7271 (2000).

28. Black, B. E. et al. Centromere identity maintained by nucleosomes assembled with histone H3 containing the CENP-A targeting domain. Mol. Cell 25, 309-322 (2007).

29. Allshire, R. C. \& Karpen, G. H. Epigenetic regulation of centromeric chromatin: old dogs, new tricks? Nat. Rev. Genet. 9, 923-937 (2008).

30. Akhmanova, A., Miedema, K. \& Hennig, W. Identification and characterization of the Drosophila histone H4 replacement gene. FEBS Lett. 388, 219-222 (1996).

31. Holmes, W. F. et al. Coordinate control and selective expression of the full complement of replication-dependent histone $\mathrm{H} 4$ genes in normal and cancer cells. J. Biol. Chem. 280, 37400-37407 (2005).

32. Long, M. et al. A novel histone $\mathrm{H} 4$ variant $\mathrm{H} 4 \mathrm{G}$ regulates rDNA transcription in breast cancer. Nucleic Acids Res. 47, 8399-8409 (2019).

33. Terme, J.-M. et al. Histone H1 variants are differentially expressed and incorporated into chromatin during differentiation and reprogramming to pluripotency. J. Biol. Chem. 286, 35347-35357 (2011).

34. Hergeth, S. P. \& Schneider, R. The H1 linker histones: multifunctional proteins beyond the nucleosomal core particle. EMBO Rep. 16, 1439-1453 (2015).

35. Strahl, B. D. \& Allis, C. D. The language of covalent histone modifications. Nature 403, 41-45 (2000). 
36. Turner, B. M. Cellular memory and the histone code. Cell 111, 285-291 (2002).

37. Carlberg, C. \& Molnár, F. The Histone Code. in Human Epigenomics (eds. Carlberg, C. \& Molnár, F.) 75-88 (Springer, 2018). doi:10.1007/978-981-10-7614-5_5.

38. Finch, J. T. \& Klug, A. Solenoidal model for superstructure in chromatin. Proc. Natl. Acad. Sci. U. S. A. 73, 1897-1901 (1976).

39. Filion, G. J. et al. Systematic protein location mapping reveals five principal chromatin types in Drosophila cells. Cell 143, 212-224 (2010).

40. Ebert, A., Lein, S., Schotta, G. \& Reuter, G. Histone modification and the control of heterochromatic gene silencing in Drosophila. Chromosome Res. Int. J. Mol. Supramol. Evol. Asp. Chromosome Biol. 14, 377-392 (2006).

41. Greil, F., de Wit, E., Bussemaker, H. J. \& van Steensel, B. HP1 controls genomic targeting of four novel heterochromatin proteins in Drosophila. EMBO J. 26, 741-751 (2007).

42. Czermin, B. et al. Physical and functional association of SU(VAR)3-9 and HDAC1 in Drosophila. EMBO Rep. 2, 915-919 (2001).

43. Tie, F., Prasad-Sinha, J., Birve, A., Rasmuson-Lestander, Å. \& Harte, P. J. A 1Megadalton ESC/E(Z) Complex from Drosophila That Contains Polycomblike and RPD3. Mol. Cell. Biol. 23, 3352-3362 (2003).

44. Fauvarque, M. O. et al. Dominant modifiers of the polyhomeotic extra-sex-combs phenotype induced by marked $\mathrm{P}$ element insertional mutagenesis in Drosophila. Genet. Res. 78, 137-148 (2001).

45. Chintapalli, V. R., Wang, J. \& Dow, J. A. T. Using FlyAtlas to identify better Drosophila melanogaster models of human disease. Nat. Genet. 39, 715-720 (2007).

46. Wang, Z. et al. Genome-wide mapping of HATs and HDACs reveals distinct functions in active and inactive genes. Cell 138, 1019-1031 (2009).

47. Zhang, P. et al. Structure of human MRG15 chromo domain and its binding to Lys36methylated histone H3. Nucleic Acids Res. 34, 6621-6628 (2006).

48. Martínez-Balbás, M. A., Tsukiyama, T., Gdula, D. \& Wu, C. Drosophila NURF-55, a WD repeat protein involved in histone metabolism. Proc. Natl. Acad. Sci. U. S. A. 95, 132-137 (1998).

49. Tie, F., Furuyama, T., Prasad-Sinha, J., Jane, E. \& Harte, P. J. The Drosophila Polycomb Group proteins ESC and $\mathrm{E}(\mathrm{Z})$ are present in a complex containing the histone-binding protein 555 and the histone deacetylase RPD3. Dev. Camb. Engl. 128, 275-286 (2001).

50. MacAlpine, H. K., Gordân, R., Powell, S. K., Hartemink, A. J. \& MacAlpine, D. M. Drosophila ORC localizes to open chromatin and marks sites of cohesin complex loading. Genome Res. 20, 201-211 (2010).

51. Allfrey, V. G., Faulkner, R. \& Mirsky, A. E. ACETYLATION AND METHYLATION OF HISTONES AND THEIR POSSIBLE ROLE IN THE REGULATION OF RNA SYNTHESIS. Proc. Natl. Acad. Sci. U. S. A. 51, 786-794 (1964).

52. Lu, X., Wang, L., Yu, C., Yu, D. \& Yu, G. Histone Acetylation Modifiers in the Pathogenesis of Alzheimer's Disease. Front. Cell. Neurosci. 9, (2015).

53. Dhalluin, C. et al. Structure and ligand of a histone acetyltransferase bromodomain. Nature 399, 491-496 (1999). 
54. Jacobson, R. H., Ladurner, A. G., King, D. S. \& Tjian, R. Structure and function of a human TAFII250 double bromodomain module. Science 288, 1422-1425 (2000).

55. Owen, D. J. et al. The structural basis for the recognition of acetylated histone H4 by the bromodomain of histone acetyltransferase gen5p. EMBO J. 19, 6141-6149 (2000).

56. Fujisawa, T. \& Filippakopoulos, P. Functions of bromodomain-containing proteins and their roles in homeostasis and cancer. Nat. Rev. Mol. Cell Biol. 18, 246-262 (2017).

57. Verdin, E. \& Ott, M. 50 years of protein acetylation: from gene regulation to epigenetics, metabolism and beyond. Nat. Rev. Mol. Cell Biol. 16, 258-264 (2015).

58. Turner, B. M. Histone acetylation as an epigenetic determinant of long-term transcriptional competence. Cell. Mol. Life Sci. CMLS 54, 21-31 (1998).

59. Berger, S. L. Histone modifications in transcriptional regulation. Curr. Opin. Genet. Dev. 12, 142-148 (2002).

60. Neely, K. E. \& Workman, J. L. Histone acetylation and chromatin remodeling: which comes first? Mol. Genet. Metab. 76, 1-5 (2002).

61. Sun, X.-J., Man, N., Tan, Y., Nimer, S. D. \& Wang, L. The Role of Histone Acetyltransferases in Normal and Malignant Hematopoiesis. Front. Oncol. 5, (2015).

62. Marmorstein, R. \& Zhou, M.-M. Writers and readers of histone acetylation: structure, mechanism, and inhibition. Cold Spring Harb. Perspect. Biol. 6, a018762 (2014).

63. Yamaguchi, Y. et al. AML1 is functionally regulated through p300-mediated acetylation on specific lysine residues. J. Biol. Chem. 279, 15630-15638 (2004).

64. Wang, L. et al. The leukemogenicity of AML1-ETO is dependent on site-specific lysine acetylation. Science 333, 765-769 (2011).

65. Gu, W. \& Roeder, R. G. Activation of p53 sequence-specific DNA binding by acetylation of the p53 C-terminal domain. Cell 90, 595-606 (1997).

66. Vervoorts, J. et al. Stimulation of c-MYC transcriptional activity and acetylation by recruitment of the cofactor CBP. EMBO Rep. 4, 484-490 (2003).

67. Santander, V. S. et al. Tubulin must be acetylated in order to form a complex with membrane $\mathrm{Na}(+), \mathrm{K}(+)$-ATPase and to inhibit its enzyme activity. Mol. Cell. Biochem. 291, 167-174 (2006).

68. Ivanov, D. et al. Eco1 is a novel acetyltransferase that can acetylate proteins involved in cohesion. Curr. Biol. CB 12, 323-328 (2002).

69. Buerki, C. et al. Functional relevance of novel p300-mediated lysine 314 and 315 acetylation of RelA/p65. Nucleic Acids Res. 36, 1665-1680 (2008).

70. Roth, S. Y., Denu, J. M. \& Allis, C. D. Histone acetyltransferases. Annu. Rev. Biochem. 70, 81-120 (2001).

71. Bowers, E. M. et al. Virtual ligand screening of the p300/CBP histone acetyltransferase: identification of a selective small molecule inhibitor. Chem. Biol. 17, 471-482 (2010).

72. Voss, A. K. \& Thomas, T. MYST family histone acetyltransferases take center stage in stem cells and development. BioEssays News Rev. Mol. Cell. Dev. Biol. 31, 1050-1061 (2009).

73. Chen, H. et al. Nuclear receptor coactivator ACTR is a novel histone acetyltransferase and forms a multimeric activation complex with $\mathrm{P} / \mathrm{CAF}$ and $\mathrm{CBP} / \mathrm{p} 300$. Cell 90, 569580 (1997). 
74. Spencer, T. E. et al. Steroid receptor coactivator-1 is a histone acetyltransferase. Nature 389, 194-198 (1997).

75. Blanco-García, N., Asensio-Juan, E., de la Cruz, X. \& Martínez-Balbás, M. A. Autoacetylation regulates P/CAF nuclear localization. J. Biol. Chem. 284, 1343-1352 (2009).

76. Carrozza, M. J., Utley, R. T., Workman, J. L. \& Côté, J. The diverse functions of histone acetyltransferase complexes. Trends Genet. TIG 19, 321-329 (2003).

77. Lee, K. K. \& Workman, J. L. Histone acetyltransferase complexes: one size doesn't fit all. Nat. Rev. Mol. Cell Biol. 8, 284-295 (2007).

78. Jeanmougin, F., Wurtz, J. M., Le Douarin, B., Chambon, P. \& Losson, R. The bromodomain revisited. Trends Biochem. Sci. 22, 151-153 (1997).

79. Mujtaba, S., Zeng, L. \& Zhou, M.-M. Structure and acetyl-lysine recognition of the bromodomain. Oncogene 26, 5521-5527 (2007).

80. Wang, X. \& Hayes, J. J. Acetylation Mimics within Individual Core Histone Tail Domains Indicate Distinct Roles in Regulating the Stability of Higher-Order Chromatin Structure. Mol. Cell. Biol. 28, 227-236 (2008).

81. Fujimoto, H. et al. A possible overestimation of the effect of acetylation on lysine residues in KQ mutant analysis. J. Comput. Chem. 33, 239-246 (2012).

82. Alvarez, F. et al. Sequential establishment of marks on soluble histones H3 and H4. J. Biol. Chem. 286, 17714-17721 (2011).

83. Campos, E. I. et al. The program for processing newly synthesized histones H3.1 and H4. Nat. Struct. Mol. Biol. 17, 1343-1351 (2010).

84. Han, J., Zhou, H., Li, Z., Xu, R.-M. \& Zhang, Z. Acetylation of lysine 56 of histone H3 catalyzed by RTT109 and regulated by ASF1 is required for replisome integrity. J. Biol. Chem. 282, 28587-28596 (2007).

85. Parthun, M. R., Widom, J. \& Gottschling, D. E. The major cytoplasmic histone acetyltransferase in yeast: links to chromatin replication and histone metabolism. Cell 87, 85-94 (1996).

86. Verreault, A., Kaufman, P. D., Kobayashi, R. \& Stillman, B. Nucleosomal DNA regulates the core-histone-binding subunit of the human Hat1 acetyltransferase. Curr. Biol. CB 8, 96-108 (1998).

87. Cook, A. J. L., Gurard-Levin, Z. A., Vassias, I. \& Almouzni, G. A specific function for the histone chaperone NASP to fine-tune a reservoir of soluble H3-H4 in the histone supply chain. Mol. Cell 44, 918-927 (2011).

88. Groth, A. et al. Regulation of replication fork progression through histone supply and demand. Science 318, 1928-1931 (2007).

89. Laskey, R. A., Honda, B. M., Mills, A. D. \& Finch, J. T. Nucleosomes are assembled by an acidic protein which binds histones and transfers them to DNA. Nature 275, 416-420 (1978).

90. Adkins, M. W., Howar, S. R. \& Tyler, J. K. Chromatin disassembly mediated by the histone chaperone Asf1 is essential for transcriptional activation of the yeast PHO5 and PHO8 genes. Mol. Cell 14, 657-666 (2004).

91. Belotserkovskaya, R. et al. FACT facilitates transcription-dependent nucleosome alteration. Science 301, 1090-1093 (2003). 
92. Park, Y.-J. \& Luger, K. Histone chaperones in nucleosome eviction and histone exchange. Curr. Opin. Struct. Biol. 18, 282-289 (2008).

93. Bowman, A. et al. sNASP and ASF1A function through both competitive and compatible modes of histone binding. Nucleic Acids Res. 45, 643-656 (2017).

94. Murzina, N. V. et al. Structural basis for the recognition of histone H4 by the histonechaperone RbAp46. Struct. Lond. Engl. 1993 16, 1077-1085 (2008).

95. Song, J.-J., Garlick, J. D. \& Kingston, R. E. Structural basis of histone H4 recognition by p55. Genes Dev. 22, 1313-1318 (2008).

96. English, C. M., Adkins, M. W., Carson, J. J., Churchill, M. E. A. \& Tyler, J. K. Structural basis for the histone chaperone activity of Asf1. Cell 127, 495-508 (2006).

97. Natsume, R. et al. Structure and function of the histone chaperone CIA/ASF1 complexed with histones H3 and H4. Nature 446, 338-341 (2007).

98. Hartl, F. U. \& Hayer-Hartl, M. Converging concepts of protein folding in vitro and in vivo. Nat. Struct. Mol. Biol. 16, 574-581 (2009).

99. Rivera, C. et al. Methylation of histone H3 lysine 9 occurs during translation. Nucleic Acids Res. 43, 9097-9106 (2015).

100. Saavedra, F. et al. PP32 and SET/TAF-I $\beta$ proteins regulate the acetylation of newly synthesized histone H4. Nucleic Acids Res. 45, 11700-11710 (2017).

101. Jasencakova, Z. et al. Replication stress interferes with histone recycling and predeposition marking of new histones. Mol. Cell 37, 736-743 (2010).

102. Loyola, A., Bonaldi, T., Roche, D., Imhof, A. \& Almouzni, G. PTMs on H3 variants before chromatin assembly potentiate their final epigenetic state. Mol. Cell 24, 309-316 (2006).

103. Stewart, M. Molecular mechanism of the nuclear protein import cycle. Nat. Rev. Mol. Cell Biol. 8, 195-208 (2007).

104. Baake, M., Bäuerle, M., Doenecke, D. \& Albig, W. Core histones and linker histones are imported into the nucleus by different pathways. Eur. J. Cell Biol. 80, 669-677 (2001).

105. Mühlhäusser, P., Müller, E.-C., Otto, A. \& Kutay, U. Multiple pathways contribute to nuclear import of core histones. EMBO Rep. 2, 690-696 (2001).

106. Xu, D., Farmer, A. \& Chook, Y. M. Recognition of nuclear targeting signals by Karyopherin- $\beta$ proteins. Curr. Opin. Struct. Biol. 20, 782-790 (2010).

107. Lee, B. J. et al. Rules for nuclear localization sequence recognition by karyopherin beta 2. Cell 126, 543-558 (2006).

108. Chook, Y. M. \& Süel, K. E. Nuclear import by karyopherin- $\beta$ s: recognition and inhibition. Biochim. Biophys. Acta 1813, 1593-1606 (2011).

109. Mosammaparast, N., Guo, Y., Shabanowitz, J., Hunt, D. F. \& Pemberton, L. F. Pathways mediating the nuclear import of histones $\mathrm{H} 3$ and $\mathrm{H} 4$ in yeast. J. Biol. Chem. 277, 862-868 (2002).

110. Soniat, M., Cağatay, T. \& Chook, Y. M. Recognition Elements in the Histone H3 and H4 Tails for Seven Different Importins. J. Biol. Chem. 291, 21171-21183 (2016).

111. Yoon, J. et al. Integrative Structural Investigation on the Architecture of Human Importin4_Histone H3/H4_Asfla Complex and Its Histone H3 Tail Binding. J. Mol. Biol. 430, 822-841 (2018). 
112. An, S., Yoon, J., Kim, H., Song, J.-J. \& Cho, U.-S. Structure-based nuclear import mechanism of histones $\mathrm{H} 3$ and $\mathrm{H} 4$ mediated by Kap123. eLife 6, (2017).

113. Campos, E. I. et al. Analysis of the Histone H3.1 Interactome: A Suitable Chaperone for the Right Event. Mol. Cell 60, 697-709 (2015).

114. Greiner, M., Caesar, S. \& Schlenstedt, G. The histones H2A/H2B and H3/H4 are imported into the yeast nucleus by different mechanisms. Eur. J. Cell Biol. 83, 511-520 (2004).

115. Mosammaparast, N., Ewart, C. S. \& Pemberton, L. F. A role for nucleosome assembly protein 1 in the nuclear transport of histones H2A and H2B. EMBO J. 21, 6527-6538 (2002).

116. Mosammaparast, N. et al. Nuclear import of histone H2A and H2B is mediated by a network of karyopherins. J. Cell Biol. 153, 251-262 (2001).

117. Krude, T. Chromatin: Nucleosome assembly during DNA replication. Curr. Biol. 5, 1232-1234 (1995).

118. Kaufman, P. D. \& Botchan, M. R. Assembly of nucleosomes: do multiple assembly factors mean multiple mechanisms? Curr. Opin. Genet. Dev. 4, 229-235 (1994).

119. Smith, S. \& Stillman, B. Purification and characterization of CAF-I, a human cell factor required for chromatin assembly during DNA replication in vitro. Cell 58, 15-25 (1989).

120. Kaufman, P. D., Kobayashi, R., Kessler, N. \& Stillman, B. The p150 and p60 subunits of chromatin assembly factor I: a molecular link between newly synthesized histones and DNA replication. Cell 81, 1105-1114 (1995).

121. Tyler, J. K., Bulger, M., Kamakaka, R. T., Kobayashi, R. \& Kadonaga, J. T. The p55 subunit of Drosophila chromatin assembly factor 1 is homologous to a histone deacetylase-associated protein. Mol. Cell. Biol. 16, 6149-6159 (1996).

122. Shibahara, K. \& Stillman, B. Replication-dependent marking of DNA by PCNA facilitates CAF-1-coupled inheritance of chromatin. Cell 96, 575-585 (1999).

123. Kadyrova, L. Y., Rodriges Blanko, E. \& Kadyrov, F. A. Human CAF-1-dependent nucleosome assembly in a defined system. Cell Cycle 12, 3286-3297 (2013).

124. Mattiroli, F. et al. DNA-mediated association of two histone-bound complexes of yeast Chromatin Assembly Factor-1 (CAF-1) drives tetrasome assembly in the wake of DNA replication. eLife 6, (2017).

125. Sauer, P. V. et al. Insights into the molecular architecture and histone H3-H4 deposition mechanism of yeast Chromatin assembly factor 1. eLife 6, (2017).

126. Brennan, L. D., Forties, R. A., Patel, S. S. \& Wang, M. D. DNA looping mediates nucleosome transfer. Nat. Commun. 7, 13337 (2016).

127. Chang, H.-W., Pandey, M., Kulaeva, O. I., Patel, S. S. \& Studitsky, V. M. Overcoming a nucleosomal barrier to replication. Sci. Adv. 2, e1601865 (2016).

128. Foltman, M. et al. Eukaryotic replisome components cooperate to process histones during chromosome replication. Cell Rep. 3, 892-904 (2013).

129. Huang, H. et al. A unique binding mode enables MCM2 to chaperone histones $\mathrm{H} 3-\mathrm{H} 4$ at replication forks. Nat. Struct. Mol. Biol. 22, 618-626 (2015).

130. Ishimi, Y., Komamura-Kohno, Y., Arai, K. \& Masai, H. Biochemical Activities Associated with Mouse Mcm2 Protein. J. Biol. Chem. 276, 42744-42752 (2001). 
131. Richet, N. et al. Structural insight into how the human helicase subunit MCM2 may act as a histone chaperone together with ASF1 at the replication fork. Nucleic Acids Res. 43, 1905-1917 (2015).

132. Annunziato, A. T. Split decision: what happens to nucleosomes during DNA replication? J. Biol. Chem. 280, 12065-12068 (2005).

133. Madamba, E. V., Berthet, E. B. \& Francis, N. J. Inheritance of Histones H3 and H4 during DNA Replication In Vitro. Cell Rep. 21, 1361-1374 (2017).

134. Cosgrove, M. S., Boeke, J. D. \& Wolberger, C. Regulated nucleosome mobility and the histone code. Nat. Struct. Mol. Biol. 11, 1037-1043 (2004).

135. Mersfelder, E. L. \& Parthun, M. R. The tale beyond the tail: histone core domain modifications and the regulation of chromatin structure. Nucleic Acids Res. 34, 26532662 (2006).

136. Yan, Q. et al. BBAP monoubiquitylates histone $\mathrm{H} 4$ at lysine 91 and selectively modulates the DNA damage response. Mol. Cell 36, 110-120 (2009).

137. Zhang, L., Eugeni, E. E., Parthun, M. R. \& Freitas, M. A. Identification of novel histone post-translational modifications by peptide mass fingerprinting. Chromosoma 112, 7786 (2003).

138. Garcea, R. L. \& Alberts, B. M. Comparative studies of histone acetylation in nucleosomes, nuclei, and intact cells. Evidence for special factors which modify acetylase action. J. Biol. Chem. 255, 11454-11463 (1980).

139. Sures, I. \& Gallwitz, D. Histone-specific acetyltransferases from calf thymus. Isolation, properties, and substrate specificity of three different enzymes. Biochemistry 19, 943951 (1980).

140. Wiegand, R. C. \& Brutlag, D. L. Histone acetylase from Drosophila melanogaster specific for H4. J. Biol. Chem. 256, 4578-4583 (1981).

141. Richman, R., Chicoine, L. G., Collini, M. P., Cook, R. G. \& Allis, C. D. Micronuclei and the cytoplasm of growing Tetrahymena contain a histone acetylase activity which is highly specific for free histone H4. J. Cell Biol. 106, 1017-1026 (1988).

142. López-Rodas, G., Georgieva, E. I., Sendra, R. \& Loidl, P. Histone acetylation in Zea mays.I. Activities of histone acetyltransferases and histone deacetylases. J. Biol. Chem. 266, 18745-18750 (1991).

143. López-Rodas, G., Tordera, V., Sánchez del Pino, M. M. \& Franco, L. Subcellular localization and nucleosome specificity of yeast histone acetyltransferases. Biochemistry 30, 3728-3732 (1991).

144. Mingarro, I., Sendra, R., Salvador, M. L. \& Franco, L. Site specificity of pea histone acetyltransferase B in vitro. J. Biol. Chem. 268, 13248-13252 (1993).

145. Brownell, J. E. \& Allis, C. D. Special HATs for special occasions: linking histone acetylation to chromatin assembly and gene activation. Curr. Opin. Genet. Dev. 6, 176184 (1996).

146. Louie, A. J., Candido, E. P. \& Dixon, G. H. Enzymatic modifications and their possible roles in regulating the binding of basic proteins to DNA and in controlling chromosomal structure. Cold Spring Harb. Symp. Quant. Biol. 38, 803-819 (1974).

147. Ruiz-Carrillo, A., Wangh, L. J. \& Allfrey, V. G. Processing of newly synthesized histone molecules. Science 190, 117-128 (1975). 
148. Jackson, V., Shires, A., Tanphaichitr, N. \& Chalkley, R. Modifications to histones immediately after synthesis. J. Mol. Biol. 104, 471-483 (1976).

149. Annunziato, A. T. \& Seale, R. L. Histone deacetylation is required for the maturation of newly replicated chromatin. J. Biol. Chem. 258, 12675-12684 (1983).

150. Chicoine, L. G., Schulman, I. G., Richman, R., Cook, R. G. \& Allis, C. D. Nonrandom utilization of acetylation sites in histones isolated from Tetrahymena. Evidence for functionally distinct H4 acetylation sites. J. Biol. Chem. 261, 1071-1076 (1986).

151. Sobel, R. E., Cook, R. G., Perry, C. A., Annunziato, A. T. \& Allis, C. D. Conservation of deposition-related acetylation sites in newly synthesized histones $\mathrm{H} 3$ and H4. Proc. Natl. Acad. Sci. U. S. A. 92, 1237-1241 (1995).

152. Parthun, M. R. Hat1: the emerging cellular roles of a type B histone acetyltransferase. Oncogene 26, 5319-5328 (2007).

153. Kuo, M. H. et al. Transcription-linked acetylation by Gen5p of histones H3 and H4 at specific lysines. Nature 383, 269-272 (1996).

154. Benson, L. J. et al. Modifications of $\mathrm{H} 3$ and $\mathrm{H} 4$ during chromatin replication, nucleosome assembly, and histone exchange. J. Biol. Chem. 281, 9287-9296 (2006).

155. Kleff, S., Andrulis, E. D., Anderson, C. W. \& Sternglanz, R. Identification of a gene encoding a yeast histone H4 acetyltransferase. J. Biol. Chem. 270, 24674-24677 (1995).

156. Eberharter, A., Lechner, T., Goralik-Schramel, M. \& Loidl, P. Purification and characterization of the cytoplasmic histone acetyltransferase B of maize embryos. FEBS Lett. 386, 75-81 (1996).

157. Chang, L. et al. Histones in transit: cytosolic histone complexes and diacetylation of $\mathrm{H} 4$ during nucleosome assembly in human cells. Biochemistry 36, 469-480 (1997).

158. Imhof, A. \& Wolffe, A. P. Purification and properties of the Xenopus Hat1 acetyltransferase: association with the 14-3-3 proteins in the oocyte nucleus. Biochemistry 38, 13085-13093 (1999).

159. Lusser, A. et al. Analysis of the histone acetyltransferase B complex of maize embryos. Nucleic Acids Res. 27, 4427-4435 (1999).

160. Ahmad, A., Takami, Y. \& Nakayama, T. Distinct regions of the chicken p46 polypeptide are required for its in vitro interaction with histones $\mathrm{H} 2 \mathrm{~B}$ and $\mathrm{H} 4$ and histone acetyltransferase-1. Biochem. Biophys. Res. Commun. 279, 95-102 (2000).

161. Ahmad, A., Nagamatsu, N., Kouriki, H., Takami, Y. \& Nakayama, T. Leucine zipper motif of chicken histone acetyltransferase-1 is essential for in vivo and in vitro interactions with the $\mathrm{p} 48$ subunit of chicken chromatin assembly factor-1. Nucleic Acids Res. 29, 629-637 (2001).

162. Banumathy, G. et al. Human UBN1 is an ortholog of yeast Hpc2p and has an essential role in the HIRA/ASF1a chromatin-remodeling pathway in senescent cells. Mol. Cell. Biol. 29, 758-770 (2009).

163. Poveda, A. et al. Hif1 is a component of yeast histone acetyltransferase B, a complex mainly localized in the nucleus. J. Biol. Chem. 279, 16033-16043 (2004).

164. Makowski, A. M., Dutnall, R. N. \& Annunziato, A. T. Effects of acetylation of histone $\mathrm{H} 4$ at lysines 8 and 16 on activity of the Hat1 histone acetyltransferase. J. Biol. Chem. 276, 43499-43502 (2001). 
165. Barman, H. K. et al. Histone acetyltransferase-1 regulates integrity of cytosolic histone H3-H4 containing complex. Biochem. Biophys. Res. Commun. 373, 624-630 (2008).

166. Ai, X. \& Parthun, M. R. The nuclear Hat1p/Hat2p complex: a molecular link between type B histone acetyltransferases and chromatin assembly. Mol. Cell 14, 195-205 (2004).

167. Tagami, H., Ray-Gallet, D., Almouzni, G. \& Nakatani, Y. Histone H3.1 and H3.3 complexes mediate nucleosome assembly pathways dependent or independent of DNA synthesis. Cell 116, 51-61 (2004).

168. Saade, E. et al. Analysis of interaction partners of $\mathrm{H} 4$ histone by a new proteomics approach. Proteomics 9, 4934-4943 (2009).

169. Ejlassi-Lassallette, A., Mocquard, E., Arnaud, M.-C. \& Thiriet, C. H4 replicationdependent diacetylation and Hat1 promote S-phase chromatin assembly in vivo. Mol. Biol. Cell 22, 245-255 (2011).

170. Drané, P., Ouararhni, K., Depaux, A., Shuaib, M. \& Hamiche, A. The death-associated protein DAXX is a novel histone chaperone involved in the replication-independent deposition of H3.3. Genes Dev. 24, 1253-1265 (2010).

171. Tscherner, M., Stappler, E., Hnisz, D. \& Kuchler, K. The histone acetyltransferase Hat1 facilitates DNA damage repair and morphogenesis in Candida albicans. Mol. Microbiol. 86, 1197-1214 (2012).

172. Agudelo Garcia, P. A. et al. Identification of multiple roles for histone acetyltransferase 1 in replication-coupled chromatin assembly. Nucleic Acids Res. 45, 9319-9335 (2017).

173. Benson, L. J. et al. Properties of the type B histone acetyltransferase Hat1: H4 tail interaction, site preference, and involvement in DNA repair. J. Biol. Chem. 282, 836842 (2007).

174. Wu, H. et al. Structural basis for substrate specificity and catalysis of human histone acetyltransferase 1. Proc. Natl. Acad. Sci. U. S. A. 109, 8925-8930 (2012).

175. Boltengagen, M. et al. A novel role for the histone acetyltransferase Hat 1 in the CENPA/CID assembly pathway in Drosophila melanogaster. Nucleic Acids Res. 44, 21452159 (2016).

176. Westhorpe, F. G. \& Straight, A. F. Functions of the centromere and kinetochore in chromosome segregation. Curr. Opin. Cell Biol. 25, 334-340 (2013).

177. Westhorpe, F. G., Fuller, C. J. \& Straight, A. F. A cell-free CENP-A assembly system defines the chromatin requirements for centromere maintenance. J. Cell Biol. 209, 789801 (2015).

178. Shang, W.-H. et al. Acetylation of histone H4 lysine 5 and 12 is required for CENP-A deposition into centromeres. Nat. Commun. 7, 1-13 (2016).

179. Nagarajan, P. et al. Histone acetyl transferase 1 is essential for mammalian development, genome stability, and the processing of newly synthesized histones H3 and H4. PLoS Genet. 9, e1003518 (2013).

180. Kelly, T. J., Qin, S., Gottschling, D. E. \& Parthun, M. R. Type B histone acetyltransferase Hat1p participates in telomeric silencing. Mol. Cell. Biol. 20, 70517058 (2000).

181. Qin, S. \& Parthun, M. R. Histone H3 and the Histone Acetyltransferase Hat1p Contribute to DNA Double-Strand Break Repair. Mol. Cell. Biol. 22, 8353-8365 (2002). 
182. Chen, L.-F., Zhou, A. S. \& West, A. E. Transcribing the connectome: roles for transcription factors and chromatin regulators in activity-dependent synapse development. J. Neurophysiol. 118, 755-770 (2017).

183. Canter, R. G., Penney, J. \& Tsai, L.-H. The road to restoring neural circuits for the treatment of Alzheimer's disease. Nature 539, 187-196 (2016).

184. Abeliovich, A. \& Gitler, A. D. Defects in trafficking bridge Parkinson's disease pathology and genetics. Nature 539, 207-216 (2016).

185. Taylor, J. P., Brown, R. H. \& Cleveland, D. W. Decoding ALS: from genes to mechanism. Nature 539, 197-206 (2016).

186. Wyss-Coray, T. Ageing, neurodegeneration and brain rejuvenation. Nature 539, 180186 (2016).

187. Gitler, A. D., Dhillon, P. \& Shorter, J. Neurodegenerative disease: models, mechanisms, and a new hope. Dis. Model. Mech. 10, 499-502 (2017).

188. Zoghbi, H. Y. \& Orr, H. T. Glutamine repeats and neurodegeneration. Annu. Rev. Neurosci. 23, 217-247 (2000).

189. Cleary, J. D. \& Ranum, L. P. W. Repeat associated non-ATG (RAN) translation: new starts in microsatellite expansion disorders. Curr. Opin. Genet. Dev. 26, 6-15 (2014).

190. Knowles, T. P. J., Vendruscolo, M. \& Dobson, C. M. The amyloid state and its association with protein misfolding diseases. Nat. Rev. Mol. Cell Biol. 15, 384-396 (2014).

191. Pearl, L. H., Schierz, A. C., Ward, S. E., Al-Lazikani, B. \& Pearl, F. M. G. Therapeutic opportunities within the DNA damage response. Nat. Rev. Cancer 15, 166-180 (2015).

192. Paull, T. T. Mechanisms of ATM Activation. Annu. Rev. Biochem. 84, 711-738 (2015).

193. McKinnon, P. J. DNA repair deficiency and neurological disease. Nat. Rev. Neurosci. 10, 100-112 (2009).

194. Bourgeron, T. From the genetic architecture to synaptic plasticity in autism spectrum disorder. Nat. Rev. Neurosci. 16, 551-563 (2015).

195. Lardenoije, R. et al. The epigenetics of aging and neurodegeneration. Prog. Neurobiol. 131, 21-64 (2015).

196. Akbarian, S., Beeri, M. S. \& Haroutunian, V. Epigenetic determinants of healthy and diseased brain aging and cognition. JAMA Neurol. 70, 711-718 (2013).

197. Amir, R. E. et al. Rett syndrome is caused by mutations in X-linked MECP2, encoding methyl-CpG-binding protein 2. Nat. Genet. 23, 185-188 (1999).

198. Ramocki, M. B. et al. Autism and other neuropsychiatric symptoms are prevalent in individuals with MeCP2 duplication syndrome. Ann. Neurol. 66, 771-782 (2009).

199. Alpatov, R. et al. A chromatin-dependent role of the fragile X mental retardation protein FMRP in the DNA damage response. Cell 157, 869-881 (2014).

200. Poisson, A. et al. Chromatin remodeling dysfunction extends the etiological spectrum of schizophrenia: a case report. BMC Med. Genet. 21, 10 (2020).

201. Sanchez-Mut, J. V. et al. Human DNA methylomes of neurodegenerative diseases show common epigenomic patterns. Transl. Psychiatry 6, e718 (2016).

202. Hodges, A. et al. Regional and cellular gene expression changes in human Huntington's disease brain. Hum. Mol. Genet. 15, 965-977 (2006). 
203. Narayanan, M. et al. Common dysregulation network in the human prefrontal cortex underlies two neurodegenerative diseases. Mol. Syst. Biol. 10, 743 (2014).

204. Prudencio, M. et al. Distinct brain transcriptome profiles in C9orf72-associated and sporadic ALS. Nat. Neurosci. 18, 1175-1182 (2015).

205. A novel gene containing a trinucleotide repeat that is expanded and unstable on Huntington's disease chromosomes. The Huntington's Disease Collaborative Research Group. Cell 72, 971-983 (1993).

206. Telenius, H. et al. Somatic and gonadal mosaicism of the Huntington disease gene CAG repeat in brain and sperm. Nat. Genet. 6, 409-414 (1994).

207. Landles, C. \& Bates, G. P. Huntingtin and the molecular pathogenesis of Huntington's disease. Fourth in molecular medicine review series. EMBO Rep. 5, 958-963 (2004).

208. Wexler, A., Wild, E. J. \& Tabrizi, S. J. George Huntington: a legacy of inquiry, empathy and hope. Brain J. Neurol. 139, 2326-2333 (2016).

209. Craufurd, D., Thompson, J. C. \& Snowden, J. S. Behavioral changes in Huntington Disease. Neuropsychiatry. Neuropsychol. Behav. Neurol. 14, 219-226 (2001).

210. Rosenblatt, A. et al. The association of CAG repeat length with clinical progression in Huntington disease. Neurology 66, 1016-1020 (2006).

211. Rosas, H. D. et al. Cerebral cortex and the clinical expression of Huntington's disease: complexity and heterogeneity. Brain J. Neurol. 131, 1057-1068 (2008).

212. Roos, R. A. C. Huntington's disease: a clinical review. Orphanet J. Rare Dis. 5, 40 (2010).

213. Dorsey, E. R. et al. Natural history of Huntington disease. JAMA Neurol. 70, 1520-1530 (2013).

214. Papoutsi, M., Labuschagne, I., Tabrizi, S. J. \& Stout, J. C. The cognitive burden in Huntington's disease: pathology, phenotype, and mechanisms of compensation. Mov. Disord. Off. J. Mov. Disord. Soc. 29, 673-683 (2014).

215. Kaltenbach, L. S. et al. Huntingtin interacting proteins are genetic modifiers of neurodegeneration. PLoS Genet. 3, e82 (2007).

216. Borrell-Pagès, M., Zala, D., Humbert, S. \& Saudou, F. Huntington's disease: from huntingtin function and dysfunction to therapeutic strategies. Cell. Mol. Life Sci. CMLS 63, 2642-2660 (2006).

217. Schulte, J. \& Littleton, J. T. The biological function of the Huntingtin protein and its relevance to Huntington's Disease pathology. Curr. Trends Neurol. 5, 65-78 (2011).

218. Zuccato, C., Valenza, M. \& Cattaneo, E. Molecular mechanisms and potential therapeutical targets in Huntington's disease. Physiol. Rev. 90, 905-981 (2010).

219. Goehler, H. et al. A protein interaction network links GIT1, an enhancer of huntingtin aggregation, to Huntington's disease. Mol. Cell 15, 853-865 (2004).

220. Cui, L. et al. Transcriptional repression of PGC-1alpha by mutant huntingtin leads to mitochondrial dysfunction and neurodegeneration. Cell 127, 59-69 (2006).

221. Dunah, A. W. et al. Sp1 and TAFII130 transcriptional activity disrupted in early Huntington's disease. Science 296, 2238-2243 (2002).

222. Li, S.-H. et al. Interaction of Huntington disease protein with transcriptional activator Sp1. Mol. Cell. Biol. 22, 1277-1287 (2002). 
223. Gervais, F. G. et al. Recruitment and activation of caspase- 8 by the Huntingtininteracting protein Hip-1 and a novel partner Hippi. Nat. Cell Biol. 4, 95-105 (2002).

224. Vecchi, M. \& Di Fiore, P. P. It's HIP to be a hub. J. Cell Biol. 170, 169-171 (2005).

225. Godin, J. D. et al. Huntingtin is required for mitotic spindle orientation and mammalian neurogenesis. Neuron 67, 392-406 (2010).

226. Keryer, G. et al. Ciliogenesis is regulated by a huntingtin-HAP1-PCM1 pathway and is altered in Huntington disease. J. Clin. Invest. 121, 4372-4382 (2011).

227. Colin, E. et al. Huntingtin phosphorylation acts as a molecular switch for anterograde/retrograde transport in neurons. EMBO J. 27, 2124-2134 (2008).

228. Caviston, J. P. \& Holzbaur, E. L. F. Huntingtin as an essential integrator of intracellular vesicular trafficking. Trends Cell Biol. 19, 147-155 (2009).

229. Gauthier, L. R. et al. Huntingtin controls neurotrophic support and survival of neurons by enhancing BDNF vesicular transport along microtubules. Cell 118, 127-138 (2004).

230. Caviston, J. P., Ross, J. L., Antony, S. M., Tokito, M. \& Holzbaur, E. L. F. Huntingtin facilitates dynein/dynactin-mediated vesicle transport. Proc. Natl. Acad. Sci. U. S. A. 104, 10045-10050 (2007).

231. Yingling, J. et al. Neuroepithelial stem cell proliferation requires LIS1 for precise spindle orientation and symmetric division. Cell 132, 474-486 (2008).

232. Ochaba, J. et al. Potential function for the Huntingtin protein as a scaffold for selective autophagy. Proc. Natl. Acad. Sci. U. S. A. 111, 16889-16894 (2014).

233. Rui, Y.-N. et al. Huntingtin functions as a scaffold for selective macroautophagy. Nat. Cell Biol. 17, 262-275 (2015).

234. Kim, M. et al. Drosophila Fip200 is an essential regulator of autophagy that attenuates both growth and aging. Autophagy 9, 1201-1213 (2013).

235. Labbadia, J. \& Morimoto, R. I. Huntington's disease: underlying molecular mechanisms and emerging concepts. Trends Biochem. Sci. 38, 378-385 (2013).

236. Saudou, F. \& Humbert, S. The Biology of Huntingtin. Neuron 89, 910-926 (2016).

237. Seredenina, T. \& Luthi-Carter, R. What have we learned from gene expression profiles in Huntington's disease? Neurobiol. Dis. 45, 83-98 (2012).

238. Kuhn, A. et al. Mutant huntingtin's effects on striatal gene expression in mice recapitulate changes observed in human Huntington's disease brain and do not differ with mutant huntingtin length or wild-type huntingtin dosage. Hum. Mol. Genet. 16, 1845-1861 (2007).

239. Vashishtha, M. et al. Targeting H3K4 trimethylation in Huntington disease. Proc. Natl. Acad. Sci. U. S. A. 110, E3027-3036 (2013).

240. Achour, M. et al. Neuronal identity genes regulated by super-enhancers are preferentially down-regulated in the striatum of Huntington's disease mice. Hum. Mol. Genet. 24, 3481-3496 (2015).

241. Langfelder, P. et al. Integrated genomics and proteomics define huntingtin CAG lengthdependent networks in mice. Nat. Neurosci. 19, 623-633 (2016).

242. Nucifora, F. C. et al. Interference by huntingtin and atrophin-1 with cbp-mediated transcription leading to cellular toxicity. Science 291, 2423-2428 (2001).

243. Bae, B.-I. et al. p53 mediates cellular dysfunction and behavioral abnormalities in Huntington's disease. Neuron 47, 29-41 (2005). 
244. Ravache, M., Weber, C., Mérienne, K. \& Trottier, Y. Transcriptional activation of REST by Sp1 in Huntington's disease models. PloS One 5, e14311 (2010).

245. Moumné, L., Betuing, S. \& Caboche, J. Multiple Aspects of Gene Dysregulation in Huntington's Disease. Front. Neurol. 4, 127 (2013).

246. Besnard, A., Galan-Rodriguez, B., Vanhoutte, P. \& Caboche, J. Elk-1 a transcription factor with multiple facets in the brain. Front. Neurosci. 5, 35 (2011).

247. West, A. E. \& Greenberg, M. E. Neuronal activity-regulated gene transcription in synapse development and cognitive function. Cold Spring Harb. Perspect. Biol. 3, (2011).

248. Lopez-Atalaya, J. P. \& Barco, A. Can changes in histone acetylation contribute to memory formation? Trends Genet. TIG 30, 529-539 (2014).

249. Labadorf, A. et al. RNA Sequence Analysis of Human Huntington Disease Brain Reveals an Extensive Increase in Inflammatory and Developmental Gene Expression. PloS One 10, e0143563 (2015).

250. Seong, I. S. et al. Huntingtin facilitates polycomb repressive complex 2. Hum. Mol. Genet. 19, 573-583 (2010).

251. von Schimmelmann, M. et al. Polycomb repressive complex 2 (PRC2) silences genes responsible for neurodegeneration. Nat. Neurosci. 19, 1321-1330 (2016).

252. Steffan, J. S. et al. Histone deacetylase inhibitors arrest polyglutamine-dependent neurodegeneration in Drosophila. Nature 413, 739-743 (2001).

253. Kazantsev, A. et al. A bivalent Huntingtin binding peptide suppresses polyglutamine aggregation and pathogenesis in Drosophila. Nat. Genet. 30, 367-376 (2002).

254. Pallos, J. et al. Inhibition of specific HDACs and sirtuins suppresses pathogenesis in a Drosophila model of Huntington's disease. Hum. Mol. Genet. 17, 3767-3775 (2008).

255. Ferrante, R. J. et al. Histone deacetylase inhibition by sodium butyrate chemotherapy ameliorates the neurodegenerative phenotype in Huntington's disease mice. J. Neurosci. Off. J. Soc. Neurosci. 23, 9418-9427 (2003).

256. Hockly, E. et al. Suberoylanilide hydroxamic acid, a histone deacetylase inhibitor, ameliorates motor deficits in a mouse model of Huntington's disease. Proc. Natl. Acad. Sci. U. S. A. 100, 2041-2046 (2003).

257. Gardian, G. et al. Neuroprotective Effects of Phenylbutyrate in the N171-82Q Transgenic Mouse Model of Huntington's Disease. J. Biol. Chem. 280, 556-563 (2005).

258. Sadri-Vakili, G. et al. Histones associated with downregulated genes are hypo-acetylated in Huntington's disease models. Hum. Mol. Genet. 16, 1293-1306 (2007).

259. Sharma, S. \& Taliyan, R. Transcriptional dysregulation in Huntington's disease: The role of histone deacetylases. Pharmacol. Res. 100, 157-169 (2015).

260. Mielcarek, M. et al. SAHA decreases HDAC 2 and 4 levels in vivo and improves molecular phenotypes in the R6/2 mouse model of Huntington's disease. PloS One 6, e27746 (2011).

261. Igarashi, S. et al. Inducible PC12 cell model of Huntington's disease shows toxicity and decreased histone acetylation. Neuroreport 14, 565-568 (2003).

262. McFarland, K. N. et al. Genome-wide histone acetylation is altered in a transgenic mouse model of Huntington's disease. PloS One 7, e41423 (2012). 
263. Valor, L. M., Guiretti, D., Lopez-Atalaya, J. P. \& Barco, A. Genomic Landscape of Transcriptional and Epigenetic Dysregulation in Early Onset Polyglutamine Disease. $J$. Neurosci. 33, 10471-10482 (2013).

264. Ryu, H. et al. ESET/SETDB1 gene expression and histone H3 (K9) trimethylation in Huntington's disease. Proc. Natl. Acad. Sci. U. S. A. 103, 19176-19181 (2006).

265. Ng, C. W. et al. Extensive changes in DNA methylation are associated with expression of mutant huntingtin. Proc. Natl. Acad. Sci. U. S. A. 110, 2354-2359 (2013).

266. Biagioli, M. et al. Htt CAG repeat expansion confers pleiotropic gains of mutant huntingtin function in chromatin regulation. Hum. Mol. Genet. 24, 2442-2457 (2015).

267. Dong, X. et al. The Role of H3K4me3 in Transcriptional Regulation Is Altered in Huntington's Disease. PloS One 10, e0144398 (2015).

268. Kim, M.-O. et al. Altered histone monoubiquitylation mediated by mutant huntingtin induces transcriptional dysregulation. J. Neurosci. Off. J. Soc. Neurosci. 28, 3947-3957 (2008).

269. McFarland, K. N. et al. Genome-wide histone acetylation is altered in a transgenic mouse model of Huntington's disease. PloS One 7, e41423 (2012).

270. De Souza, R. A. G. et al. DNA methylation profiling in human Huntington's disease brain. Hum. Mol. Genet. 25, 2013-2030 (2016).

271. Thomas, B. et al. A novel method for detecting 7-methyl guanine reveals aberrant methylation levels in Huntington disease. Anal. Biochem. 436, 112-120 (2013).

272. Wang, F. et al. Genome-wide loss of 5 -hmC is a novel epigenetic feature of Huntington's disease. Hum. Mol. Genet. 22, 3641-3653 (2013).

273. Deng, Q., Zeng, Q., Qian, Y., Li, C. \& Yang, Y. Research on the karyotype and evolution of Drosophila melanogaster species group. J. Genet. Genomics Yi Chuan Xue Bao 34, 196-213 (2007).

274. Adams, M. D. et al. The Genome Sequence of Drosophila melanogaster. Science 287, 2185-2195 (2000).

275. Myers, E. W. et al. A Whole-Genome Assembly of Drosophila. Science 287, 2196-2204 (2000).

276. Yamaguchi, M. \& Yoshida, H. Drosophila as a Model Organism. Adv. Exp. Med. Biol. 1076, 1-10 (2018).

277. Pandey, U. B. \& Nichols, C. D. Human disease models in Drosophila melanogaster and the role of the fly in therapeutic drug discovery. Pharmacol. Rev. 63, 411-436 (2011).

278. Castle, W. E. Inbreeding, Cross-Breeding and Sterility in Drosophila. Science 23, 153153 (1906).

279. Kaufman, T. C. A Short History and Description of Drosophila melanogaster Classical Genetics: Chromosome Aberrations, Forward Genetic Screens, and the Nature of Mutations. Genetics 206, 665-689 (2017).

280. Brand, A. H. \& Perrimon, N. Targeted gene expression as a means of altering cell fates and generating dominant phenotypes. Dev. Camb. Engl. 118, 401-415 (1993).

281. Duffy, J. B. GAL4 system in drosophila: A fly geneticist's swiss army knife. genesis 34, $1-15$ (2002).

282. Jackson, G. R. et al. Polyglutamine-expanded human huntingtin transgenes induce degeneration of Drosophila photoreceptor neurons. Neuron 21, 633-642 (1998). 
283. Romero, E. et al. Suppression of neurodegeneration and increased neurotransmission caused by expanded full-length huntingtin accumulating in the cytoplasm. Neuron 57, 27-40 (2008).

284. Lee, W.-C. M., Yoshihara, M. \& Littleton, J. T. Cytoplasmic aggregates trap polyglutamine-containing proteins and block axonal transport in a Drosophila model of Huntington's disease. Proc. Natl. Acad. Sci. U. S. A. 101, 3224-3229 (2004).

285. Marsh, J. L., Pallos, J. \& Thompson, L. M. Fly models of Huntington's disease. Hum. Mol. Genet. 12 Spec No 2, R187-193 (2003).

286. Gilestro, G. F. \& Cirelli, C. pySolo: a complete suite for sleep analysis in Drosophila. Bioinformatics 25, 1466-1467 (2009).

287. Trapnell, C. et al. Differential gene and transcript expression analysis of RNA-seq experiments with TopHat and Cufflinks. Nat. Protoc. 7, 562-578 (2012).

288. Graveley, B. R. et al. The developmental transcriptome of Drosophila melanogaster. Nature 471, 473-479 (2011).

289. Graveley, B. R. et al. The Developmental Transcriptome of Drosophila melanogaster. Nature 471, 473-479 (2011).

290. Peixoto, L. \& Abel, T. The role of histone acetylation in memory formation and cognitive impairments. Neuropsychopharmacol. Off. Publ. Am. Coll. Neuropsychopharmacol. 38, 62-76 (2013).

291. Lim, C. et al. Functional Role of CREB-Binding Protein in the Circadian Clock System of Drosophila melanogaster. Mol. Cell. Biol. 27, 4876-4890 (2007).

292. Sandler, J. E. \& Stathopoulos, A. Quantitative Single-Embryo Profile of Drosophila Genome Activation and the Dorsal-Ventral Patterning Network. Genetics 202, 15751584 (2016).

293. Taylor, J. P. et al. Aberrant histone acetylation, altered transcription, and retinal degeneration in a Drosophila model of polyglutamine disease are rescued by CREBbinding protein. Genes Dev. 17, 1463-1468 (2003).

294. Ahmad, K. \& Henikoff, S. The histone variant H3.3 marks active chromatin by replication-independent nucleosome assembly. Mol. Cell 9, 1191-1200 (2002).

295. Chatterjee, S. et al. A novel activator of CBP/p300 acetyltransferases promotes neurogenesis and extends memory duration in adult mice. J. Neurosci. Off. J. Soc. Neurosci. 33, 10698-10712 (2013).

296. Bodai, L., Pallos, J., Thompson, L. M. \& Marsh, J. L. Pcaf modulates polyglutamine pathology in a Drosophila model of Huntington's disease. Neurodegener. Dis. 9, 104106 (2012).

297. Barbaro, B. A. et al. Comparative study of naturally occurring huntingtin fragments in Drosophila points to exon 1 as the most pathogenic species in Huntington's disease. Hum. Mol. Genet. 24, 913-925 (2015).

298. Faragó, A., Zsindely, N. \& Bodai, L. Mutant huntingtin disturbs circadian clock gene expression and sleep patterns in Drosophila. Sci. Rep. 9, 7174 (2019).

299. Ciurciu, A., Komonyi, O., Pankotai, T. \& Boros, I. M. The Drosophila histone acetyltransferase Gcn5 and transcriptional adaptor Ada2a are involved in nucleosomal histone H4 acetylation. Mol. Cell. Biol. 26, 9413-9423 (2006). 
300. Blackwell, J. S., Wilkinson, S. T., Mosammaparast, N. \& Pemberton, L. F. Mutational analysis of $\mathrm{H} 3$ and $\mathrm{H} 4 \mathrm{~N}$ termini reveals distinct roles in nuclear import. J. Biol. Chem. 282, 20142-20150 (2007).

301. Ge, Z. et al. Sites of Acetylation on Newly Synthesized Histone H4 Are Required for Chromatin Assembly and DNA Damage Response Signaling. Mol. Cell. Biol. 33, 32863298 (2013).

302. Ma, X.-J., Wu, J., Altheim, B. A., Schultz, M. C. \& Grunstein, M. Deposition-related sites K5/K12 in histone $\mathrm{H} 4$ are not required for nucleosome deposition in yeast. Proc. Natl. Acad. Sci. U. S. A. 95, 6693-6698 (1998).

303. Shibahara, K., Verreault, A. \& Stillman, B. The N-terminal domains of histones H3 and H4 are not necessary for chromatin assembly factor-1- mediated nucleosome assembly onto replicated DNA in vitro. Proc. Natl. Acad. Sci. U. S. A. 97, 7766-7771 (2000).

304. Koo, S. J. et al. ATAD2 is an epigenetic reader of newly synthesized histone marks during DNA replication. Oncotarget 7, 70323-70335 (2016).

305. Park, C. S., Rehrauer, H. \& Mansuy, I. M. Genome-wide analysis of H4K5 acetylation associated with fear memory in mice. BMC Genomics 14, 539 (2013).

306. Ruan, K. et al. Histone $\mathrm{H} 4$ acetylation required for chromatin decompaction during DNA replication. Sci. Rep. 5, 1-10 (2015).

307. Peleg, S. et al. Altered histone acetylation is associated with age-dependent memory impairment in mice. Science 328, 753-756 (2010).

308. Shogren-Knaak, M. et al. Histone H4-K16 acetylation controls chromatin structure and protein interactions. Science 311, 844-847 (2006).

309. Schiltz, R. L. et al. Overlapping but distinct patterns of histone acetylation by the human coactivators p300 and PCAF within nucleosomal substrates. J. Biol. Chem. 274, 11891192 (1999). 


\section{VIII. Összefoglalás}

A Huntington-kór egy olyan dominánsan öröklődő, késői megjelenésű, progresszív neurodegeneratív betegség, amely minden esetben halálos kimenetelü, és a mai napig nem létezik rá hatásos gyógymód. A Huntingtin gén 210 kb hosszúságú, 67 exont tartalmaz. Az első exonban az open reading frame-en belül van egy instabil, polimorf CAG trinukleotid ismétlődés, melynek expanziója funkciónyeréses (gain of function) mutációhoz vezet. Egészséges személyeknél a CAG ismétlődések száma 9-36 között váltakozik. Mutáció következtében a CAG ismétlődések száma 36-121 érték közé emelkedik, ami megváltoztatja a gén funkcióját. Minél hosszabb az ismétlődések száma, annál gyorsabb és súlyosabb lefolyású a betegség. ${ }^{206} 207$ A nagyméretű Huntingtin (Htt) fehérje főként a citoplazmában található meg, azonban hibás proteolítikus hasítások következtében olyan $\mathrm{N}$-terminális fragmentumok keletkeznek, melyek bejutnak a sejtmagba. ${ }^{207} 208$

A Huntington-kórra jellemző összetett patomechanizmus egyik eleme a génkifejeződés hibás szabályozása, amely részben annak tulajdonítható, hogy a különböző hiszton módosítások is zavart szenvednek. A HD során megfigyelhető hiszton acetilációs zavarokat részben a CREB-binding protein (CBP) és a Pcaf hiszton acetiltranszferáz aktivitású fehérjék kötődése, mHtt aggregátumokba történő csapdázódása okozza. ${ }^{242}{ }^{252}$ Drosophila és egér modellen kimutatták, hogy a hiszton deacetilázok (HDAC) gátlása jótékony hatást fejt ki a HD fenotípusra. ${ }^{252} 253254$ Azonban jelenleg nem ismert, hogy mely hisztonok milyen aminosavain keresztül érvényesül a széles spektrumú HDAC-k gátlásával megvalósuló tüneteket enyhítő hatás.

A disszertációmban bemutatott kísérletsorozattal azt a célt tüztük ki, hogy megvizsgáljuk a Drosophila Hat1 H4 hiszton specifikus hiszton acetiltranszferáz, valamint a H4/His4r acetiláció szerepét normál körülmények között és a mutáns Huntingtin fehérje okozta proteopáthiás stressz esetén is. A Hat1 hiszton acetiltranszferáz funkcióját még nem vizsgálták korábban a Huntington-kórral összefüggésben. Ez az enzim föként a citoplazmában van jelen és a H4 hiszton 5-ös és 12-es lizinjeinek acetilálását végzi, ami egy univerzálisan előforduló diacetilációs jel az eukarióta organizmusokban. ${ }^{152}$ A H4 kanonikus hiszton és His4r variáns hiszton fehérje aminosav szinten megegyezik egymással, csak expressziós szabályozásukban lehet eltérés. ${ }^{30}$ Feltételezhető, hogy a H3 hiszton és annak H3.3 variánsaihoz hasonló módon ${ }^{294}$, az aktívan átíródó génrégiókban a His4r lecseréli a kanonikus H4 hiszton fehérjét. Ezért a His4r fehérje potenciálisan acetilálható pozícióit terveztük megvizsgálni a Huntington-kór patomechanizmusában szerepet játszó lehetséges epigenetikai targetek keresése céljából.

Kísérleteinkhez a Huntington-kór Drosophila modelljét alkalmaztuk, amely bizonyítottan alkalmas a betegség tanulmányozására, ugyanis a meghosszabbodott poliglutamin domént hordozó mutáns Huntingtin fehérje ugyanúgy aggregátumokat képez az egyedek agyában neurodegenerációt okozva, és ezzel hasonló mozgási és cirkadián ritmus zavarokhoz, valamint élettartam csökkenéshez vezetve, mint ami a humán pácienseknél megfigyelhető ${ }^{297}$ 298 
Kísérleteinkhez Hat1 mutáns valamint His4r transzgenikus Drosophila melanogaster törzseket hoztunk létre. A Hatl funkcionális vizsgálatához P-elem remobilizációval elöállítottunk egy Hatl deléciós törzset, amelyből a gén kódoló régiója szinte teljesen hiányzik, eltávolítva a HAT domént is, és ennek kísérleti kontrolljaként egy olyan precíz revertáns vonalat, ahol a gén helyreállt a transzpozon kiugrása után. Továbbá létrehoztunk olyan transzgenikus Drosophila törzseket, melyekben a His4r hiszton variáns fehérje olyan indukálható változatai találhatóak, amelyek C-terminális részükön egy FLAG-tag-et hordoznak, az N-terminálisán található acetilálható lizin aminosavak (K5, K8, K12, K16) pontmutációi pedig folytonos acetilált állapotot (lizin $(\mathrm{K})$ - glutamin $(\mathrm{Q})$ csere) vagy módosítatlan állapotot (lizin $(\mathrm{K})-\operatorname{arginin}(\mathrm{R})$ csere) mimikálnak. A kísérleteink kontrolljaként elöállítottunk egy olyan transzgenikus törzset is, amely a His4r gént módosítatlan formában hordozza. Mivel a Hatl a vizsgált eukarióta organizmusokban a $\mathrm{H} 4$ hiszton 5-ös és 12-es lizinjeinek acetilálását végzi, ezért létrehoztunk egy olyan His4r szubsztitúciós törzset is, melyben mind az 5-ös, mint a 12-es lizint kódoló tripletet kicseréltük arginint kifejezőre, (amely módosítatlan állapotot mimikál mindkét pozícióban,) vagyis egy olyan körülményt utánoz, ahol a Hatl hiszton acetiltranszferáz nem acetilálja a His4r hisztont.

Mind a Hat1 deléciós mutáns, mind a neuronálisan UAS-His4r transzgént expresszáló vonalak életképesnek és fertilisnek bizonyultak. A Hatl deléció azonban kismértékü szemiletális fenotípushoz vezetett.

A His4r transzgenikus törzsek validálása során a transzgének kifejeződésével kapcsolatban azt állapítottuk meg, hogy míg mRNS szinten nincs jelentős eltérés a kifejeződésük mértékében (ahogy azt a helyspecifikus transzgén integráció esetén vártuk), addig a fehérjék neuronális mennyisége az adott módosítás függvényében változik. Az acetilációt mimikáló glutamin módosítás minden pozíció esetén alacsonyabb fehérje expressziót eredményezett a módosítatlan lizint mimikáló arginin módosításnál. Feltételezhetően valamilyen fehérje expresszió vagy lebontásbeli különbség okozza az acetilált lizint mimikáló módosítások esetén a csökkent fehérje szintet. Ennek ellenére fenotípusbeli különbséget neuronális expresszió esetén nem tapasztaltunk a törzsek között, életképesség csökkenés és neurodegeneráció nem volt megfigyelhető. A transzgenikus, pontmutáns His4r fehérjék sejten belüli lokalizációját fluoreszcens mikroszkópiával vizsgálva megállapítottuk, hogy mindegyik módosított fehérje változat bejutott a sejtmagba, lokalizációjukban nem volt különbség.

A Hat1 deléciós mutáns fukcionális vizsgálatának első lépéseként az enzim targetjeinek meghatározására fókuszáltunk. Eredményeink a korábbi megállapításokkal egybecsengenek, a H4 hiszton 5-ös és 12-es lizinjeinek acetilálását végzi, amely aktivitás specifikusnak tünik erre a két pozícióra (a 8-as pozíció acetilációs állapotában nem történt változás). Meglepő módon 0-6 órás deléciós mutáns embriókban ez az aktivitás csaknem teljesen eltünik. Továbbá a Hat1 hiánya a H3 hiszton 18-as lizinjének acetilációs állapotát is befolyásolja, ami viszont egy indirekt hatás eredménye lehet, ugyanis korábbi irodalmi adatok alapján a Hat1nek nincsen $\mathrm{H} 3$ specifikus katalítikus aktivitása ${ }^{85} 175$.

A korábbi elképzelések szerint a H4 K5 és K12 diacetiláció, amely az eukarióta organizmusokban egy univerzális citoplazmatikus hiszton módosítás, szükséges a H4 hiszton sejtmagba jutásához. Ezért módosítatlan 5-ös és 12-es lizineket mimikáló (lizin - arginin 
csere) His4r konstrukciót, illetve Hat1 deléciós háttéren vad típusú His4r konstrukciót hordozó transzgenikus állatokon teszteltük ezt a hipotézist. Konfokális mikroszkópiával sikerült megállapítanunk, hogy mind a vad típusú His4r transzgenikus fehérje a Hat1 hiánya esetén, mind az acetilálhatatlan His4r transzgenikus fehérje vad típusú háttéren sejtmagi lokalizációt mutat. Tehát a K5K12 diacetilációs módosítás nem nélkülözhetetlen a H4 / His4r hiszton sejtmagba jutásához.

A Hat1 deléció hatására jelentkező jelentősebb molekuláris változások ellenére nincs kifejezett hatása sem az állatok hőstressz türésére, sem a cirkadián aktivitásukra. Pozíció effektus variegációs tesztünk alapján részt vehet egy zártabb kromatin szerkezet kialakításában vagy fenntartásában. Ezért transzkriptomikai analízist is végeztünk a Hat1 által befolyásolt génexpressziós változások vizsgálatára. Az RNS expressziós vizsgálat alapján több, mint 2000 gén expressziós mintázata változott meg szignifikánsan az enzim hiányában 6-12 órás embriókban. Ezen génexpressziós változások 2/3-a emelkedett expressziót (upregulációt), 1/3-a pedig csökkent expressziót (downregulációt) mutatott. A változások jelentős része egy fejlődési késésnek tulajdonítható, ami lehet egy megváltozott kromatin szerveződés eredménye, azonban a megemelkedett génexpressziós változások kb. $10 \%$-a, a csökkent génexpressziós vátozásoknak pedig kb. a 30\%-a nem magyarázható ezzel a jelenséggel. Ezek közül a gének közül a biológiai folyamatokban való részvételük szerint a Hatl deléciós mutáns embriókban megemelkedett expressziójú gének főként fejlődési és transzlációs szabályozók, a lecsökkent expresziójú gének pedig alap metabolizmusban részt vevő faktorokat kódolnak.

A Hat1-nek a mutáns Huntingtin kiváltotta proteopátiás stresszre gyakorolt hatását a betegség transzgenikus modelljében tesztelve azt tapasztaltuk, hogy a föként citoplazmatikus Hat1 részleges hiánya - eltérően az eddig vizsgált nukleáris acetiltranszferáz enzimektől 252295 - csökkentette a neurodegeneráció mértékét. Mivel korábbi megállapításaink szerint a Hat1 részt vehet a zárt kromatin szerkezet kialakításában, ezért elképzelhető, hogy a részleges hiánya esetén kialakuló nyitottabb kromatin szerkezet az oka a tünetek enyhülésének.

A His4r szubsztitúciók esetén változatos eredményeket kaptunk. Az UAS-His4r transzgént vad típusú formában expresszáló egyedek életképessége is jelentősen csökkent a csak mHtt-t expresszáló „,beteg” kontroll egyedekhez képest. Egyik módosított His4r transzgént hordozó kategória életképessége sem érte el a csak mHtt fehérjét expresszáló egyedekét, a His $4 r$ gént vad típusú formában expresszáló egyedeknél azonban a 8-as és a 16-os pozícióban acetilációt mimikáló (lizin - glutamin csere) módosítást hordozók jobb életképességünek bizonyultak. Az 5-ös pozícióban acetilációt mimikáló módosítást hordozó állatok kis mértékben mutattak rosszabb kikelési arányt a módosítatlan His4r gént hordozókhoz képest. A 12-es pozícióban módosítást hordozó egyedek pedig egyáltalán nem keltek ki. Azonban az életképes kategóriák esetén a módosítatlan lizint mimikáló (lizin - arginin csere) módosítás minden esetben gyengébb életképességet mutatott a többi kategóriánál. Az élethossz vizsgálatok alapján szintén a 8 -as és 16-os pozíciók változásai tüntek pozitív irányba befolyásoló hatásúnak. A neurodegenerációs vizsgálat során a 16-os pozíció szintén pozitív találat volt, azonban az 5-ös pozíció acetilációt mimikáló módosítása is jótékony hatásúnak bizonyult. 
A fenotípusbeli javulások alapján az UAS-His4r transzgének közül az 5-ös és a 8-as pozíció acetilációját mimikáló módosítások, valamint a 16-os pozíció tűnnek potenciálisan pozitív hatásúnak a Huntington-kór patogenezisére. Azonban ezek közül az K5Q és K16Q acetilációt mimikáló módosítások fehérje expressziós szintje valamilyen processzingbeli eltérésnek köszönhetően sokkal alacsonyabb más módosított változatokénál. Ezért a fenotípus javulások oka ezekben az esetekben lehet az alacsonyabb mennyiségü fehérje szint. A neurodegenerációs vizsgálatok és a fehérje expressziós adatok alapján úgy tủnik, hogy a His4r-K8 pozíció acetilált állapota és His4r-K16 pozíció acetilálatlan állapota jelentőséggel bírhat a Huntington-kór patomechanizmusában. 


\section{Summary}

Huntington's disease (HD) is a fatal, dominantly inherited, late-onset, progressive neurodegenerative disorder, for which there is no available cure or effective treatment. The human Huntingtin (HTT) gene is $210 \mathrm{~kb}$ long and consists of 67 exons. In the first exon of HTT there is an unstable polymorphic CAG trinucleotide (encoding for glutamine, Q) repeat, which, if expands over a certain repeat length causes gain of function mutation. In healthy individuals the number of CAG repeats are between 9 and 36. If the number of CAG repeats exceeds 36 repeat units, the resulting elongated polyglutamine domain changes the properties of the Huntingtin protein and induce the complex pathogenesis of HD. Longer repeats cause earlier disease onset and more severe symptoms. 206207

The large Huntingtin $(\mathrm{Htt})$ protein is mainly localized to the cytoplasm, but incorrect proteolytic cleavage of mutant $\mathrm{Htt}(\mathrm{mHtt})$ results in short $\mathrm{N}$-terminal fragments that can be imported to the nucleus. ${ }^{207} 208$ A main part of the multifaceted pathomechanism of HD is the dysregulation of gene expression, which partially caused by disturbed modification of histones. CREB-binding protein (CBP) and PCAF histone acetyltransferases, among others, bind to $\mathrm{mHtt}$ proteins, which leads to incorrect histone acetylation in the HD. ${ }^{242} 252$ In Drosophila and mouse HD models some inhibitors of histone deacetylases (HDACs) were shown to ameliorate the HD symptoms previously. ${ }^{252} 253254$ However, it is still not elucidated that the acetylation state of which lysine residues of which histone proteins might play a crucial role in the alleviating effect of broad spectrum HDAC inhibitors.

In the experiments that form the basis of my Ph.D. thesis our aims were to study the functions of the histone $\mathrm{H} 4$ specific Drosophila Hat1 histone acetyltransferase and to examine the potential involvement of Hat 1 and specific H4/His4r acetylation states in protheopathic stress conditions caused by mutant Huntingtin. The function of Hat1 has not yet been characterized in connection with the Huntington's disease. This enzyme is mainly localized in the cytoplasm and acetylates the 5th and 12th lysines (K) of nascent histone H4. This H4K5K12 diacetylation is a universal mark in eukaryotic organisms. ${ }^{152}$ Canonical H4 and the His4r variant histone proteins have identical amino acid sequences but the regulation of their expression is different. ${ }^{30}$ We hypothesized, that similarly to the case of histone $\mathrm{H} 3$ and its variant H3.3 ${ }^{294}$, canonical H4 histone is replaced by His $4 \mathrm{r}$ at sites of active gene expression. Based on this assumption we decided to study those lysines of His4r, which can be acetylated to find epigenetic marks that are involved in the pathomechanism of Huntington's disease.

For our experiments I used a Drosophila model of HD that was proven to be appropriate to study the cellular aspects of HD pathogenesis. In this model expression of an N-terminal fragment of $\mathrm{mHtt}$ leads to effects similar to those characteristic for the human disease: mutant Huntingtin protein forms intracellular aggregates in the brain of flies, cause neurodegeneration, movement and circadian rhythm defects, and reduced lifespan. ${ }^{297} 298$

We generated Hat1 mutant and UAS-His4r transgenic Drosophila melanogaster strains. The Hat $1^{\Delta 57}$ amorphic mutant was generated by P-element remobilization that resulted in the deletion of almost the whole coding sequence of the gene including the HAT domain. For experimental control we chose a precise revertant line in which the gene was restored after 
remobilization of the transposon. We also generated transgenic Drosophila strains that carry inducible His $4 r$ histone transgenes that are labeled with a C-terminal FLAG-tag and contain substitutions in their $\mathrm{N}$-terminal tail regions that mimic the acetylated (lysine (K) to glutamine (Q) change) or unacetylated/unmodified forms (lysine to arginine (R) change) of specific lysine residues $(\mathrm{K} 5, \mathrm{~K} 8, \mathrm{~K} 12, \mathrm{~K} 16)$. For experimental control we made a transgenic line that carries a wild-type (not modified) His $4 r$ gene. We also made a transgenic line with $\mathrm{K} 5$ and K12 double substitutions to arginine (K5R-K12R) to imitate a condition in which the target lysine residues of the Hat1 histone acetyltransferase cannot be acetylated. The Hat1 mutant and the neuronally expressed His $4 r$ transgenes were viable and fertile, although loss of Hat 1 caused mild sub-lethality.

During the validation of the His $4 r$ transgenic strains we found that the expression of the transgenes did not differ at the mRNA level (as we expected because of the site specific integration), but their protein levels if expressed in neurons depended on the specific substitution. The $\mathrm{K}$ to $\mathrm{Q}$ substitutions that mimic the acetylated state showed lower protein levels in every position than $\mathrm{K}$ to $\mathrm{R}$ substitutions that mimic unacetylated/unmodified state. Presumably, lower protein levels in the case of acetylation mimetic His $4 \mathrm{r}$ proteins is caused by differences in the protein expression, processing or turnover. However, based on fluorescence microscopy analysis the cellular localization of the various modified His $4 \mathrm{r}$ proteins was alike, all variants showed nuclear localization. To ascertained that the His4r point mutant transgenes are not neurotoxic we analyzed the phenotypes of the strains and found that neuronal expression of the various His $4 r$ mutants did not cause neurodegeneration or reduced viability.

Our first step in the functional analysis of Hatl mutant was the identification of the targets of the enzyme. Our results, similar to previous observations in other species, indicate that Hat1 acetylates the K5 and K12 lysine residues of histone $\mathrm{H} 4$ and this activity seems to be specific for these positions as the acetylation state of H4K8 did not change. Interestingly, in 06 hours old Hat1 mutant embryos these H4K5 and K12 acetylations almost completely disappeared. Furthermore, lack of Hat1 influenced the acetylation state of the H3K18 residue, that presumably, is an indirect effect because according to previous studies Drosophila Hat1 does not have $\mathrm{H} 3$ specific catalytic activity ${ }^{85} 175$.

As cytoplasmic diacetylation of K5 and K12 residues of nascent histone $\mathrm{H} 4$ is a universal post-translational histone modification in eukaryotic organisms it was hypothesized that it might be necessary for the nuclear transport of $\mathrm{H} 4$. To test this hypothesis we generated a transgenic strain carrying a His4r-K5RK12R transgene mimicking unacetylated/unmodified lysine residues at these positions (with lysine to arginine change) and a strain that carries a wild-type His4r construct in Hat1 null background. Using immunofluorescence confocal microscopy we found that both transgenic wild-type His4r in Hat1 null background and transgenic His4r-K5RK12R proteins in wild-type background showed correct nuclear localization. Consequently, the K5K12 diacetylation mark is not necessary for the nuclear import of $\mathrm{H} 4$ / His4r histones.

Despite of the significant molecular changes in Hat1 mutants, it has no remarkable effects on the heat stress resistance or the circadian rhythm of the flies. Using position effect 
variegation analysis we found that Hat 1 may play a role in the formation or maintenance of closed chromatin. Therefore, we performed RNA-seq transcriptome analyzis to identify and analyze gene expression changes caused by the lack of Hat1. Our data shows that the expression of more than 2000 genes changed significantly in 6-12 hours old Hat1 null embryos. $2 / 3$ of the genes showing altered expression levels were upregulated, while $1 / 3$ were downregulated. The majority of the observed transcriptional alterations were presumably the consequence of a developmental delay, which could be explained by altered formation and structure of chromatin. However, dysregulated transcription in $10 \%$ of the upregulated genes and $30 \%$ of the downregulated genes could not be explained by phenomena. Most of the upregulated genes in this group play roles in developmental and translational regulation while the majority of the downregulated genes encode factors that participate in metabolism.

While examining the effects that the mainly cytoplasmic Hat1 exert on mutant Huntingtin induced phenotypes in the transgenic model of the disease we found that, contrary to the previously examined nuclear histone acetyltransferase enzymes ${ }^{252} 295$, its reduced levels ameliorated neurodegeneration. As we previously found that Hat1 may play a role in the formation of closed chromatin, it is conceivable that a more relaxed chromatin structure caused by reduced levels of Hat 1 is the reason for the reduced symptoms.

In the analysis of UAS-His4r epigenetic mark mimetic substitutions we have got diverse results. The co-expression of wild-type His $4 \mathrm{r}$ transgene along with $\mathrm{mHtt}$ reduced lifespan compared to the lifespan of contol flies expressing mHtt only. We found that none of the mHtt - His4r ${ }^{\text {mimic }}$ co-expressing categories had improved viability compared to $\mathrm{mHtt}$ expressing control flies, but flies co-expressing $\mathrm{mHtt}$ and acetylated lysine mimicking (lysine to glutamine change) K8Q or K16Q mutated His4r transgenes had better viability than flies coexpressing $\mathrm{mHtt}$ and wild-type His4r. The acetylation mimetic K5Q substitution had a modest worsening effect on viability compared to the wild-type His4r transgene expressing flies in the HD model. Both His4r K12Q and K12R modified transgenes were lethal if co-expressed with mHtt. In general, in the case of each tested His4r lysine residue (except for K12 modifications that gave no viable offspring) unacetylated lysine mimetic His4r transgenes had lower viability if co-expressed with $\mathrm{mHtt}$ than acetylation mimetic His $4 \mathrm{r}$ transgenes. Furthermore, His4r K8Q and K16Q acetylation mimetic modifications had also positive effect on lifespan. In neurodegeneration tests we found that besides the K16Q substitution the K5Q modification had a positive effect on the survival of photoreceptor neurons.

Among the post-translational modification mimetic UAS-His4r transgenes the acetylation mimetic K5Q, K8Q and both of the K16 modifications had positive, relieving effect on some of the phenotypes of the HD model flies. However, the His4r K5Q and K16Q proteins showed lower protein levels feasibly due to different protein processing and turnover. Therefore, the reason for the observed positive effects on HD phenotypes in these cases is most likely the lower level of His4r protein. Based on protein expression data and results of the neurodegeneration assays acetylation mimetic His4r-K8Q and the unacetylated mimetic His4r-K16R transgenes had a significant, protein level independent positive effect on the pathomechanisms induced by mutant Htt. 


\section{Publikációs lista}

\section{X.1. A doktori eljárás alapját képező 2 db közlemény}

1. Varga, Júlia; Korbai, Szabina; Neller, Alexandra; Zsindely, Nóra; Bodai, László.

Hat1 acetylates histone $\mathrm{H} 4$ and modulates the transcriptional program in Drosophila embryogenesis.

Scientific Reports 9(1): 17973 (2019)

2. $\quad$ Varga, Júlia; Dér, Nikolett Petra; Zsindely, Nóra; Bodai, László.

Green tea infusion alleviates neurodegeneration induced by mutant Huntingtin in Drosophila. Nutritional Neuroscience, 23(3):183-189. (2020)

\section{X.2. Referált folyóiratban megjelent közlemények [Impakt faktorok összege: 7,961]}

\section{X.2.1. A disszertáció témájához kapcsolódó közlemények}

Varga, Júlia; Korbai, Szabina; Neller, Alexandra; Zsindely, Nóra; Bodai, László

Hat1 acetylates histone $\mathrm{H} 4$ and modulates the transcriptional program in Drosophila embryogenesis.

Scientific Reports 9(1): 17973 (2019) [Impakt faktor: 4,011]

\section{X.2.2. Egyéb közlemények}

Varga, Júlia; Dér Nikolett Petra; Zsindely, Nóra; Bodai, László.

Green tea infusion alleviates neurodegeneration induced by mutant Huntingtin in Drosophila. Nutritional Neuroscience, 23(3):183-189. (2020) [Impakt faktor: 3,950]

\section{X.3. Egyéb szakmai anyagok}

\section{X.3.1. Konferencia elöadások (elöadóként)}

1. Varga, Júlia. Egy feltételezett ubikvitin receptor jellemzése. XXXII. Országos Tudományos Diákköri Konferencia, Biológia Szekció. Pécs, 2015.04.08-10.

2. Varga, Júlia; Deák, Péter; Pál, Margit; Kovács, Levente. Egy feltételezett ubikvitin receptor jellemzése. 16. Kolozsvári Biológus Napok. Kolozsvár, Románia, 2015.04.16-18.

3. Varga, Júlia. Examination of potential epigenetical targets of Huntington's disease in Drosophila melanogaster. PhD Conference, SZTE TTIK Biológia Doktori Iskola. (Szeged, 2018. 05.28-30.) In: "Dissertation Summaries", Acta Biologica Szegediensis, 62(1), pp. 83105. (2018)

4. Varga, Júlia; Korbai, Szabina; Neller, Alexandra; Zsindely, Nóra; Bodai, László. A Drosophila Hat1 acetilálja a H4 hisztont és hozzájárul a megfelelő transzkripciós profil 
kialakulásához az embriogenezis során. XVIII. Genetikai Műhelyek Magyarországon minikonferencia. Szeged, 2019. 09. 12.

\section{Konferencia elöadások (társszerzöként)}

1. Ürmösi, Adél; Varga, Júlia; Bodai, László. His4r deléciós mutáns létrehozása P-elem ugratás segítségével Drosophila melanogasterben. In: Fenesi, A; László, Z; Markó, B (szerk.) 17. Kolozsvári Biológus Napok. Kolozsvár, Románia: Babes-Bolyai Tudományegyetem, (2016) pp. 89-89.

\section{X.3.2. Konferencia poszterek}

1. Varga, Júlia; Zsindely, Nóra; Bodai, László. Generation and analysis of mutations of the Drosophila Hat1 gene. Annual Meeting of the Hungarian Biochemical Society. (Szeged, Magyarország: 2016.08.28 -2016.08.31.) In: BIOKÉMIA: A MAGYAR BIOKÉMIAI EGYESÜLET FOLYÓIRATA 15: 3 pp. 66-66. Paper: P65 , 1 p. (2016)

2. Zsindely, Nóra; Varga, Júlia; Bodai, László. Probing the epigenetic background of Huntington's disease using histone PTM mimics. Annual Meeting of the Hungarian Biochemical Society. (Szeged, Magyarország: 2016.08.28 -2016.08.31.) In: BIOKÉMIA: A MAGYAR BIOKÉMIAI EGYESÜLET FOLYÓIRATA 15: 3 pp. 40-40. Paper: P4 , 1 p. (2016)

3. Zsindely, Nóra; Varga, Júlia; Faragó, Anikó; Bodai, László. Exploring the role of histone modifications in Huntington's disease. 2nd Danube Conference on Epigenetics. (Budapest, Magyarország, 2016.10.05-2016.10.08.) In: Tamás, Arányi; Bálint, L Bálint; Petra, Hajkova; Ana, Pombo; Laszlo, Tora (szerk.) 2nd Danube Conference on Epigenetics (2016) p. 57 Paper: P-05

4. Varga, Júlia; Faragó, Anikó; Zsindely, Nóra; Bodai, László. dHat1 acetyltransferase acetylates Histone $\mathrm{H} 4$ and modulates gene expression in Drosophila embryos. Hungarian Molecular Life Sciences 2017. (Eger, Magyarország, 2017.03.31-2017.04.02.) In: Zsuzsanna, Heiszler; Róbert, Hohol; Nóra, Éles-Etele (szerk.) Hungarian Molecular Life Sciences 2017 : Programme and Book of abstracts. Budapest, Magyarország : Diamond Congress Ltd., (2017) pp. 208-209. 